\title{
Exploring the Power of County-Level Regional Classifications on Predicting Sex-Specific All-Cause Mortality in the United States
}

Julia Kay Wolf

Follow this and additional works at: https://researchrepository.wvu.edu/etd

\section{Recommended Citation}

Wolf, Julia Kay, "Exploring the Power of County-Level Regional Classifications on Predicting Sex-Specific All-Cause Mortality in the United States" (2017). Graduate Theses, Dissertations, and Problem Reports. 6968.

https://researchrepository.wvu.edu/etd/6968

This Thesis is protected by copyright and/or related rights. It has been brought to you by the The Research Repository @ WVU with permission from the rights-holder(s). You are free to use this Thesis in any way that is permitted by the copyright and related rights legislation that applies to your use. For other uses you must obtain permission from the rights-holder(s) directly, unless additional rights are indicated by a Creative Commons license in the record and/ or on the work itself. This Thesis has been accepted for inclusion in WVU Graduate Theses, Dissertations, and Problem Reports collection by an authorized administrator of The Research Repository @ WVU. For more information, please contact researchrepository@mail.wvu.edu. 


\title{
Exploring the Power of County-Level Regional Classifications on Predicting Sex-Specific All-Cause Mortality in the United States
}

\author{
Julia Kay Wolf \\ Thesis submitted \\ to the Eberly College of Arts and Sciences \\ at West Virginia University \\ in partial fulfillment of the requirements for the degree of \\ Master of Arts in \\ Sociology \\ Jeralynn S. Cossman, Ph.D., Chair \\ Christopher P. Scheitle, Ph.D. \\ Douglas J. Myers, Sc.D.
}

Department of Sociology and Anthropology

Morgantown, West Virginia

2017

Keywords: Garreau, mortality, regional classification, sex-specific, smoking, US Census Divisions, Woodard 


\title{
ABSTRACT \\ Exploring the Power of Different Regional Classifications on Predicting
Sex-Specific All-Cause Mortality in the United States
}

\author{
Julia Kay Wolf
}

Sex-specific mortality rates have been found to differ across regions of the United States; however, these areas are typically the broad Census Bureau regions (i.e., Midwest, Northeast, South, and West) that do not consider sociological factors known to affect health. By testing the predictive capabilities of theoretically driven regional classifications distinguished at countylevel, I explore whether there are more accurate ways of assessing mortality differences across the United States. Specifically, I use the US Census Bureau divisions and regional groupings produced by Joel Garreau (1981) and Colin Woodard (2011) to predict sex-specific, ageadjusted, all-cause mortality for 2008-2012 (centered on 2010). Garreau's Nine Nations of North America uses the economic activities and priorities of various regions to divide the US while Woodard's American Nations: A History of the Eleven Rival Regional Cultures of North America uses the historical settlement of the US to generate culturally different nations. I examine the mediating effects of several county-level contextual and demographic factors, health behavior characteristics (including smoking), and socioeconomic measures (including labor force participation). Results suggest that Woodard's "American Nations" slightly outperform the other regional classifications, but the differences are negligible once other mediating factors are taken into account. Findings demonstrate that daily smoking behavior is the strongest predictor of county-level mortality variation for males and females. Researchers and policymakers should continue to find ways to reduce smoking, particularly in the south. 


\section{Table of Contents}

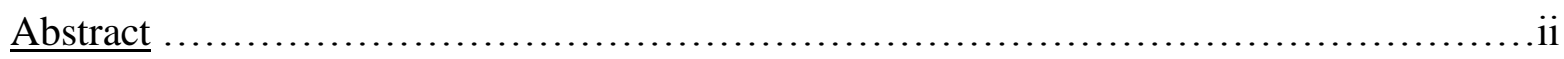

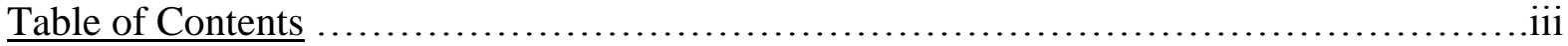

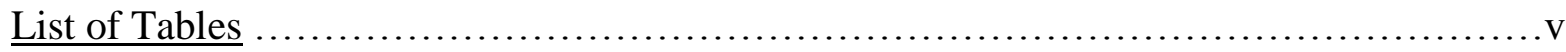

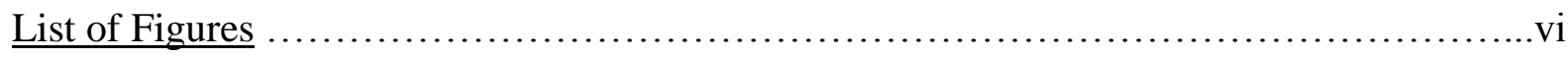

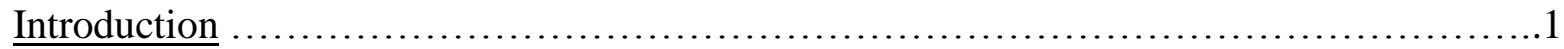

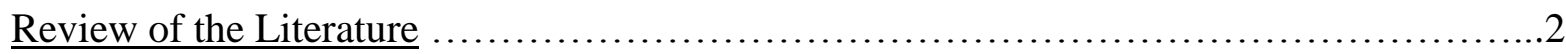

Mortality Disparities: People vs. Place ...................................2

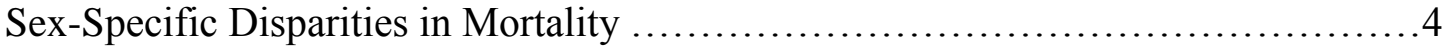

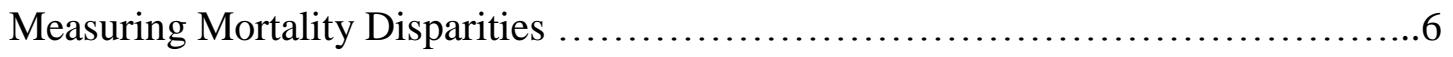

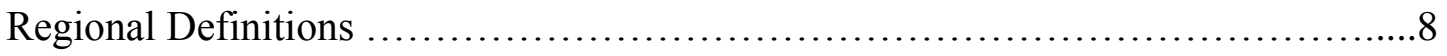

US Census Bureau Divisions ........................................8

Woodard's American Nations: A History of the Eleven Rival Regional

Cultures of North America ............................................10

Garreau's The Nine Nations of North America ............................13

Applying Regional Classifications to Sex-Specific Mortality Disparities ...................16

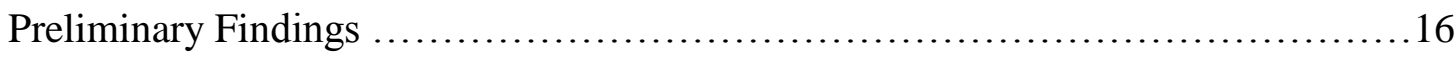

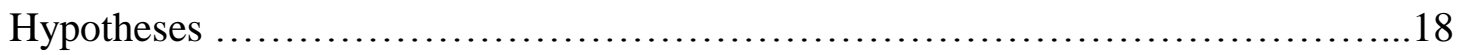

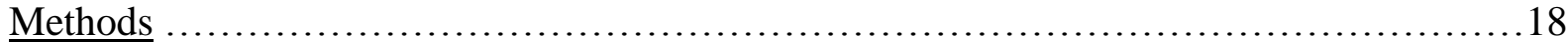

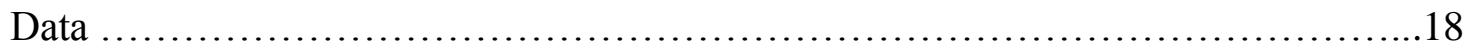

Dependent Variables ..............................................19

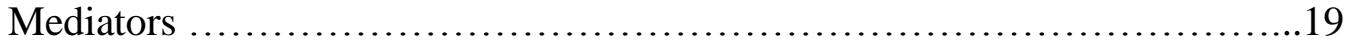

Regional Classifications .........................................21

Analyses ............................................................... 21

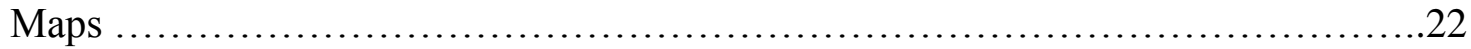

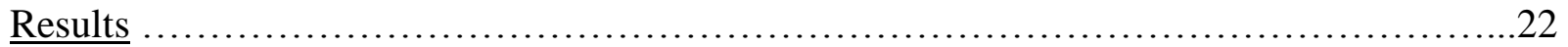

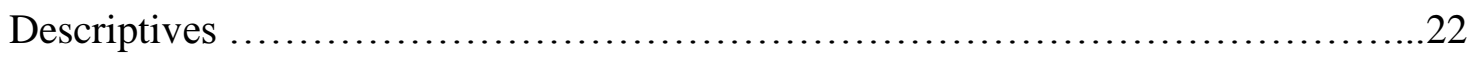

Model 1a and 1b: Male and Female Mortality without Mediators ...................25

Model 2a and 2b: Male and Female Mortality with "Place" Mediators ...............26

Model 3a and 3b: Male and Female Mortality with "People" Mediators ..............27 
Model 4a and 4b: Male and Female Mortality with Mediators (except Smoking

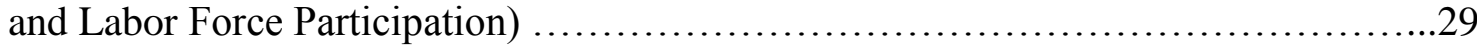

Model 5a and 5b: Male and Female Mortality with All Mediators ...................31

Comparison of Models for US Census Divisions .................................. 34

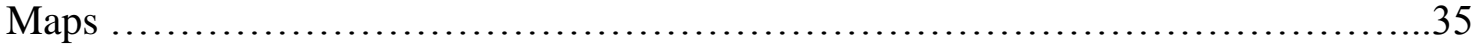

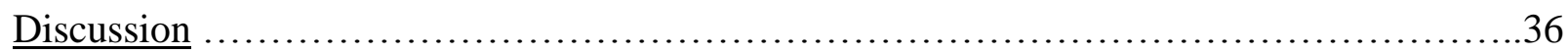

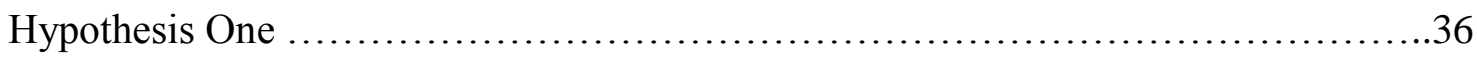

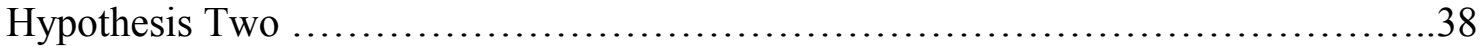

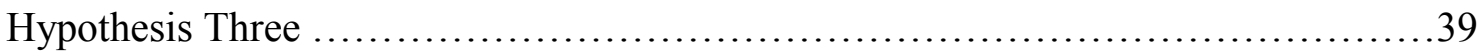

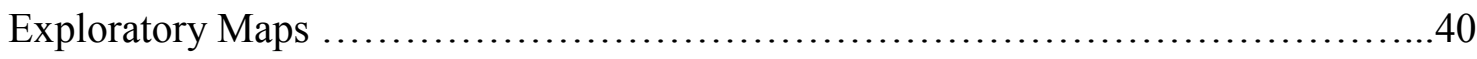

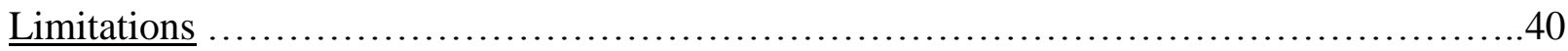

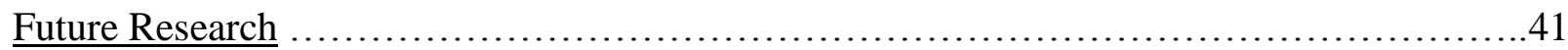

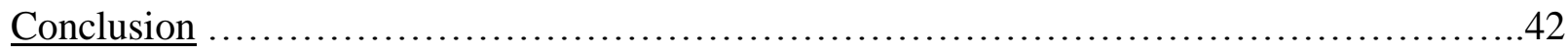

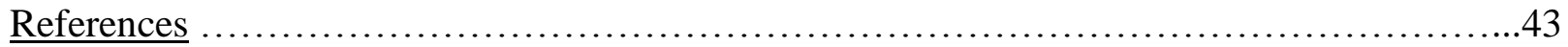

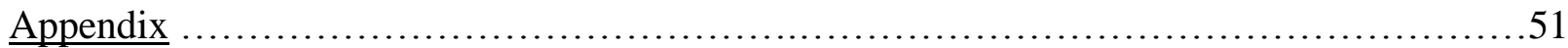




\section{List of Tables}

Table 1. Comparison of Model Fit from Preliminary Analyses .............................51

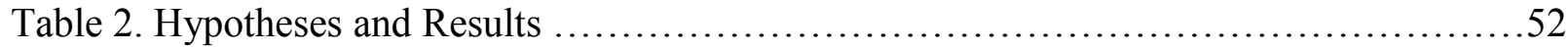

Table 3a. Descriptives of US Census Bureau Divisions ...............................53

Table 3b. Descriptives of US Census Bureau Divisions - Male ...........................54

Table 3c. Descriptives of US Census Bureau Divisions - Female .......................55

Table 4a. Descriptives of Woodard's American Nations ..................................56

Table 4b. Descriptives of Woodard's American Nations - Male ............................58

Table 4c. Descriptives of Woodard's American Nations - Female ...............................59

Table 5a. Descriptives of Garreau's Nine Nations ..................................60

Table 5b. Descriptives of Garreau's Nine Nations - Male .............................61

Table 5c. Descriptives of Garreau's Nine Nations - Female ............................62

Table 6. Model 1a: Male Mortality without Mediators ................................63

Table 7. Model 1b: Female Mortality without Mediators ...............................64

Table 8. Model 2a: Male Mortality with "Place" Mediators ..............................65

Table 9. Model 2b: Female Mortality with "Place" Mediators .............................67

Table 10. Model 3a: Male Mortality with "People" Mediators ..............................69

Table 11. Model 3b: Female Mortality with "People" Mediators ............................71

Table 12. Model 4a: Male Mortality with Mediators (except Smoking and Labor Force

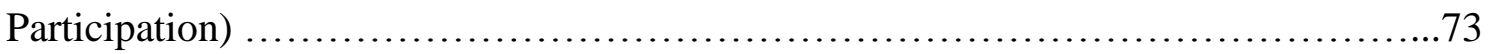

Table 13. Model 4b: Female Mortality with Mediators (except Smoking and Labor Force

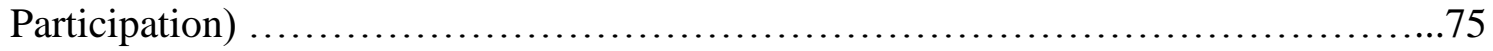

Table 14. Model 5a: Male Mortality with All Mediators ....................................77

Table 15. Model 5b: Female Mortality with All Mediators ..................................80

Table 16. Male Mortality Models: Census ...........................................83

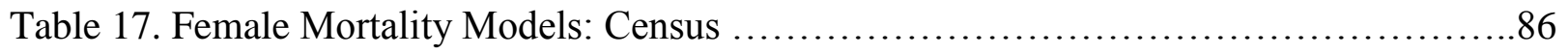




\section{List of Figures}

\section{$\underline{\text { Regional Classifications }}$}

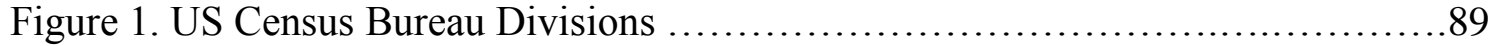

Figure 2. Woodard's "American Nations" ........................................ 90

Figure 3. Garreau's "Nine Nations" .....................................................

\section{ArcGIS Maps with Mortality}

Figure 4. Female Age-Adjusted All-Cause US Mortality with Census Divisions ........92

Figure 5. Male Age-Adjusted All-Cause US Mortality with Census Divisions ..........93

Figure 6. Female Age-Adjusted All-Cause US Mortality with Woodard's "American

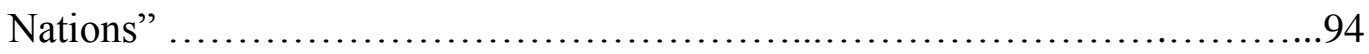

Figure 7. Male Age-Adjusted All-Cause US Mortality with Woodard's "American

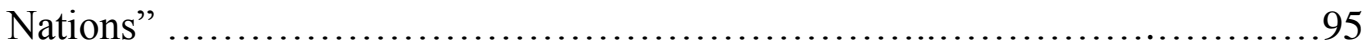

Figure 8. Female Age-Adjusted All-Cause US Mortality with Garreau's "Nine Nations" .96

Figure 9. Male Age-Adjusted All-Cause US Mortality with Woodard's "American

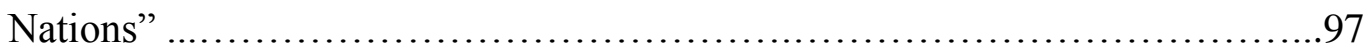

Figure 10. Female Age-Adjusted All-Cause US Mortality with Woodard, Garreau, and

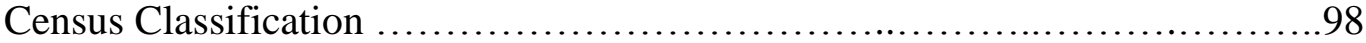

Figure 11. Female Age-Adjusted All-Cause US Mortality with Woodard, Garreau, and Census Classification 
Research has found "persistent clusters" of high and low mortality rates across the United States from 1968 to 2002 (Cossman et al. 2007). Sex-specific mortality rates have been found to differ among US regions as well (Ezzati et al. 2008; Kindig and Cheng 2013; Montez and Berkman 2014); however, these areas are typically colloquially named regions without long-term definitive boundaries (e.g., Appalachia) or are the broad Census Bureau regions (i.e., Midwest, Northeast, South, and West) that did not consider health-related sociological factors when they were created. These broad regional areas are also large and may be missing disparities within or across their borders. One study found "eight Americas," (as opposed to four regions) or districts of the US distinct in several demographic, socioeconomic, and geographic characteristics, that showed differing mortality rates between males and females (Murray et al. 2006). Nevertheless, these areas were generated via empirical data (including homicide rates) without a general theory to deduce their formations.

By testing the predictive capabilities of theoretically driven regional classifications distinguished at county-level, I explore whether there are more accurate ways of assessing mortality differences across the US. Specifically, I will use the regional groupings produced by Joel Garreau and Colin Woodard. Garreau's Nine Nations of North America uses (1981) the economic activities and priorities of various regions to divide the US while Woodard's American Nations: A History of the Eleven Rival Regional Cultures of North America (2011) uses the historical settlement of the US to generate culturally different nations. On the other hand, the Census Bureau's divisions were created in 1910 based roughly off of the three largest natural draining systems (e.g., the Mississippi River) in America and follow larger state boundaries (US Census Bureau 2015c). The two former classifications provide theories (e.g., economic values, historical settlement) as to why these nations might have noticeable differences in mortality rates, and this study will allow social demographers to see how these contextual variations each affect males and females.

Preliminary testing has found that Woodard's nations predict 2010 mortality rates better than Garreau's or the US Census Divisions (Wolf, Cossman, and Myers 2016; Cossman, Wolf, and Myers 2016a; Cossman, Wolf, and Myers 2016b); however, Wolf and colleagues (2016) did not include health indicators such as obesity or physical activity levels, Cossman and colleagues (2016a) did not include these indicators nor was examined by sex, and Cossman and colleagues (2016b) did not include measures of smoking or participation in the labor force - variables 
known to greatly affect female mortality rates (Montez and Barnes 2015; Meara, Richards, and Cutler 2008; Montez and Zajacova 2013). In this thesis I plan to build upon previous findings by taking into account these important factors. I also visually demonstrate the spatial layout of the sex-specific, age-adjusted, all-cause 2010 mortality rates via choropleth maps of the US while overlaying these various regional classifications.

REVIEW OF THE LITERATURE

Mortality Disparities: People vs. Place

Mortality disparities across the US have interested researchers from a variety of fields and perspectives. From sociologists measuring income differentials (e.g., Caldwell and Diamond 1979) to those investigating geographical differences in socioeconomic inequalities (e.g., Krieger et al. 2002) to epidemiologists and public health scholars examining cause-specific disease across education levels (e.g., Miech et al. 2009) to those suggesting marketing strategies regarding tobacco use in rural areas (e.g., Roberts et al. 2016), mortality disparities are widely known and investigated.

Although the US has seen mortality rates declining over the past century (Cutler, Deaton, and Lleras-Muney 2006), disparities in all-cause mortality based on educational attainment (Montez et al. 2011; Hayward, Hummer, and Sasson 2015), sex (Kindig and Cheng 2013), socioeconomic status (Nandi, Glymour, and Subramanian 2014), rurality in association with population size and adjacency to urban areas (James and Cossman 2016), and race/ethnicity (Satcher et al. 2005) have been increasing or remained stagnant in recent years. A recent report by the National Center for Health Statistics shows that life expectancy for both males and females has decreased from 2014 to 2015 (Xu et al. 2016). Case and Deaton (2015) have also shown an increase in all-cause mortality rates of middle-aged white non-Hispanics over a fourteen year period (1999-2013) that was propelled by those with lower levels of education; however, a response by Snyder (2016) indicates that geographical distinctions may play a larger role in the mortality increase and deserves further research.

Emerging as the study "relating environment and community characteristics to health and disease," public health later reshaped its focus to individual-level factors' roles in transmitting diseases; this transition was due in part to the introduction of germ theory and the increase in the chronic diseases (Diez-Roux 1998). However, the tides have been changing yet again as epidemiologists, sociologists, and demographers call for a return to an emphasis on contextual 
(e.g., economic, geographic) influences on health outcomes rather than on mainly individual behaviors and characteristics (Diez-Roux 1998; Myers 2008; Myers 2010; Montez and Berkman 2014). Indeed Kindig and Cheng (2013) found socioeconomic factors (e.g., "rate of children living in poverty") ${ }^{1}$ had similar or even stronger associations with mortality rate changes than individual behaviors (e.g., smoking, obesity). Furthermore, another study points out that "individual-level incomes have been significantly associated with mortality since the early twentieth century, significant ecological correlations between income and mortality at the state level are more recent" (Kunitz 2014: 28).

While these individual-level characteristics have been contributing to mortality inequalities, geographical effects on mortality levels have also been highlighted. For example, the built (i.e., human-made) environment one resides in influences the possibility of experiencing health risk factors that can lead to certain types of death (e.g., traffic accidents; Lucy 2003) or disease (e.g., ischemic heart disease; Hankey, Marshall, and Brauer 2015). Neighborhood factors have been found to independently influence mortality risk net of individual socioeconomic characteristics (LeClere, Rogers, and Peters 1997; Huie, Hummer, and Rogers 2002). Singh and his colleagues found disparities in all-cause youth mortality vary by socioeconomic deprivation and geographic distribution (Singh et al. 2012). In another study, Singh and Siahpush (2013) found that even though US mortality rates decreased from 1969 to 2009, rural-urban disparities in all-cause mortality (and a few other major causes of death) grew while poverty levels only partially explained the differences; however, poverty greatly affected mortality in non-metropolitan areas and the largest differences in the rural-urban mortality gap were found in high poverty areas. Additionally, when incorporating race and poverty, the gaps in mortality rates are even more pronounced, and show that "poor blacks in non-metropolitan areas experiencing two to three times higher risks of all-cause and premature mortality than affluent blacks and whites in metropolitan areas" (Singh and Siahpush 2013).

Spatial research has also found that area depravity (Singh 2003) and rurality in association with population size and adjacency to urban areas (James and Cossman 2016) affect disparities in death rates. Disparities between rural-urban (Singh and Siahpush 2013) areas as well as metropolitan-nonmetropolitan counties (Cosby et al. 2008) highlight the need to look

\footnotetext{
${ }^{1}$ Kindig and Cheng (2013) also used "percentage of a county's population with a college education" as a contextual socioeconomic measure; however, I use sex-specific percentages of each county's educational attainment as measure of the characteristics of the "people" in the county rather than of the location (i.e., "place") of the county.
} 
beyond just personal characteristics. For example, metropolitan areas (e.g., urban areas, cities) had higher rates of mortality in early US history than nonmetropolitan areas, but as sanitation services improved in these densely packed places where contagious diseases could spread readily, the disparity disappeared (Haines 2001). A 2008 article showed that this trend had actually reversed in the mid-1980s with higher mortality rates in nonmetropolitan areas (Cosby et al. 2008). The authors' discussion also poses the question of whether or not the disparity trends are found in particular US regions (Cosby et al. 2008). Additionally, research has shown that "persistent clusters of mortality" (as measured by groups of counties) have remained strong over a 35 year span in the US; even through changes in policies and medical advances, certain counties maintain higher or lower mortality rates (Cossman et al. 2007). Personal characteristics and contextual factors both play roles in influencing longevity.

Sex-Specific Disparities in Mortality

Large regional patterns in mortality have been considered, particularly comparing male and female death rates. Kindig and Cheng (2013) examined changes in county-level male and female mortality rates and found that a county's contextual region affected how mortality rates increased, decreased, or remained the same over time, especially for females. For instance, while counties in the West had a 3\% higher increase in male mortality than Northeast counties, counties in the South and West had up to a $6 \%$ higher increase in female mortality compared those in the Northeast (Kindig and Cheng 2013). Moreover, they found a startling disparity in the increase of mortality rates for men and women across the US; men experienced an increase in mortality rates in $3.4 \%$ of counties while women experienced an increase in $42.8 \%$ of the counties (Kindig and Cheng 2013). Montez and Berkman (2014) found slight regional mortality disparities for males and females by educational attainment. For example, similar trends of increasing mortality for less educated women and decreasing mortality for highly educated women were seen in most regions, but there were no decreases in mortality for women at any education level in the South and there were no significant increases in mortality for low-educated women in the Northeast (Montez and Berkman 2014). As for the men, the gap between mortality rates in the highly educated and the less educated changed little over time compared to the growing gaps in female mortality by education level (Montez and Berkman 2014). Additionally, patterns in the mortality gradient by education level differed more by gender than 
by race (Montez and Berkman 2014). Thus, regional differences appear to be influencing male and female mortality rates differently, potentially more so for females than males.

The reviewed literature has only considered four broadly determined regions (i.e., Northeast, Midwest, West, and South), created without any theoretical consideration, thus leaving explanations for these variations unanswered. Are there local economic or health policies influencing the health behaviors or outcomes of certain groups in that area? Are there different cultural trends across regions affecting men and women's health unequally? American citizens' local residences typically share common cultural norms or values which may affect health behaviors or access to facilities regarding food and physical activity (Papas et al. 2007). This idea warrants further scrutiny at more local levels.

Others have taken up the challenge and examined what could be driving sex-specific mortality disparities at the county-level. Murray and colleagues (2006) generated "eight Americas" that divide the US into similar groups of counties by race, location, population density, particular measures of income, and homicide rates. Examining changes between 1982 and 2001, they demonstrated large mortality disparities across the groups for males and females, particularly due to chronic diseases, injuries, and other elements (Murray et al. 2006). HIV and homicide rates influenced widening gaps between Americas for males in the late 1980s to the early 1990s, and mortality rates for low-income females were seen to increase in areas like Appalachia and the Mississippi Valley over the time period studied (Murray et al. 2006).

However, Murray and his colleagues' (2006) nations were created via the empirical data instead of by a theoretical framework. In other words, they grouped together similar people and mortality rates by their numbers-leaving one to then rely on inductive reasoning to explain why these populations might be similar-rather than working from a theoretical perspective and examining if predicted distinct regions actually do share similar mortality outcomes. Here, I compare two theoretically generated regional classifications of the US to an administrative classification that does not propose meaningful cultural distinctions. It is these conceived cultural similarities that may explain differences in regional mortality rates. While Woodard (2011) touches on historical differences between the sexes and Garreau (1981) briefly mentions any, there are clearly differences in mortality patterns for males and females; therefore, it is germane to consider if and how these historical, cultural, and economic variations are working distinctively for males and females. 


\section{Measuring Mortality Disparities}

For both men and women, "healthy and unhealthy places," or "persistent clusters of mortality," with similar historical features can be found in various areas across the US (Cossman et al. 2004; Cossman et al. 2007). Large groupings of counties appeared to have central counties that had multiple time periods of high levels of mortality (i.e., one standard deviation above the national mean of mortality rates) with surrounding counties that had fewer time periods of high levels of mortality and counties surrounding those with fewer time periods yet (Cossman et al. 2004). In a way, there were pockets of high levels of mortality rates, particularly in "The South," that lessened as one traveled away from the center of the concentration. However, this study had not taken into account whether or not the mortality rate trends were themselves increasing or decreasing, so such an observation is made cautiously (Cossman et al. 2004).

Nevertheless, and more pertinent to this present research, the authors noted that these zones of low and high levels of mortality traversed state lines (Cossman et al. 2004). By focusing on the county-level, trends that transcend state lines can be observed - a prominent feature that using US Census Bureau regions does not afford. Cossman et al.'s (2004) study illustrated the importance of taking space (and time) into account when analyzing mortality rates and hinted at the potential significance of colloquially defined regions (i.e., "The South”) compared to the administrative regions created by the US Census Bureau. A theoretical framework that operationalizes commonly referred to regions, such as "The South," could allow us to test their ability to predict mortality rates and give us a foundation for figuring out which geographically similar characteristics influence residents' health.

Studying mortality differences by US Census Bureau regions may show spatial patterns, but does indicate cultural or economic factors influencing any disparities in those areas. The arguments put forth by Garreau (1981) and Woodard (2011) contend that cultures and economic values cross the state lines used by the US Census Bureau classifications. Therefore, continuing to use the regional definitions of the US Census Bureau may be missing important social factors - which can be considered "fundamental causes of health inequalities" - that can help explain mortality or other health disparities by location (Link and Phelan 2005). Using an economic or cultural lens could then provide a way of approaching segments of America with different mortality rates while providing a theoretical framework for the disparities. 
Since data is not collected on US residents based on Garreau or Woodard's regions, I found and used data measured consistently over time in relatively homogeneous units that are comparable across all three regional definitions (Batagelj et al. 2014: 357). US counties fulfill this need as small geographic areas with stable borders from which data has regularly been collected (Batagelj et al. 2014). Using counties is also necessary (versus states) because, while the US Census Bureau regions are grouped by states, Garreau and Woodard's nations transcend state lines. While neighborhoods may have provided a more nuanced glimpse into Garreau and Woodard's regions, these geographic levels are relatively unstable over time and data has not been consistently collected from them nationally (Batagelj et al. 2014).

The US Census Bureau collects data for a variety of reasons. Its primary concern is collecting a comprehensive population count to apportion seats in the House of Representatives; however, over time data has been collected for other legal, social, economic, and financial purposes (Geography 2015b). These demands have forced the US Census Bureau to "recognize many kinds of geographic areas — legal, administrative, and statistical — as the framework for the tabulation and presentation of data from its decennial, economic, agriculture, and governments censuses, as well as its periodic sample surveys and estimates programs" (Geography 2015b). Understanding these geographic levels helps the field of public health as well.

The US is broken down into several geographic entities: four regions, nine divisions, 57 states or statistically equivalent entities, 3,248 counties and statistically equivalent entities, and several other groupings (Geography 2015b). ${ }^{2}$ Although multiple geographic areas are defined by the US Census Bureau, they can be divided into two main categories: 1) legal and administrative entities and 2) statistical entities (Geography 2015b). Legal (e.g., states, counties, and their statistically equivalent entities ${ }^{3}$ ) and administrative (e.g., ZIP codes) entities are geographic groupings created by "legal actions, treaties, statutes, ordinances, resolutions, court decisions, and the like"(Geography 2015b: 2-2). Legal and administrative entities can be used by local officials to oversee various programs or regulate elections (Geography 2015b). The US Census Bureau's four regions and nine divisions (described in the next section), and several other groupings are considered statistical entities that have been established "where the geographic coverage of the legal areas is incomplete, inadequate, or inconsistent over time, or is

\footnotetext{
${ }^{2}$ See the Geographic Areas Reference Manual for more information and an illustration of their geographic hierarchy (Geography 2015b).

3 'Statistically equivalent entities' are different from 'statistical entities.'
} 
nonexistent" (Geography 2015b: 2-2). Statistical entities do not have official legal boundaries (i.e., they are not run by some type of a government), but rather evolved from tradition and are used for data presentation purposes (Geography 2015b). Thus, these regions/divisions are commonly used in previous research, but their boundaries do not indicate unique political areas.

Garreau and Woodard are not the first to have tried to organize the US into regions other than those put forth by the US Census Bureau. According to Lieske, arranging the US into different regions to elucidate various political and institutional policies was brought to the forefront of research in 1984 by Elazar (Lieske 1993). To create his subcultural regions, Elazar classified parts of the nation into one or more of three political subcultures coined individualistic, moralistic, or traditionalistic (Elazar 1984). Like Woodard (2011), Elazar's (1984) classifications stem from the historical settlement of areas by diverse groups. He created a continuum of eight categories that indicate various combinations of his subcultures and placed each state along it while also referencing nine regions they fit in that are similar to the census divisions (Elazar 1984). Elazar's innovative typology sparked a myriad of cultural mappings; however, few of them rely on "replicable, statistical procedures," including Garreau's (Lieske 1993: 889). Additionally, Lieske includes a criticism of Elazar's state-level and "large substate regions" classifications, suggesting a distinction of subcultures at the county-level (Lieske 1993: 889). The grouping of the US Census divisions by state may also miss cultural distinctions at the county-level; however, Garreau and Woodard's classifications by counties allow for a more nuanced creation of large regional boundaries that supposedly include culturally similar people.

The US Census Bureau's divisions are statistical entities commonly used as geographical indicators for research in mortality disparities, but they may be failing to account for cultures that transcend states lines. By using Woodard (2011) and Garreau's (1981) refined regional classifications, I plan to compare their empirical capability of predicting sex-specific mortality rates in the US to the US Census Bureau's nine divisions.

\section{Regional Definitions}

\section{US Census Bureau Divisions}

While the US had distinguished geographic regions since its conception, these classifications were not initially used in concurrence with census data (US Census Bureau 2015c). The US Census Office (now the US Census Bureau) did not include regional divisions until 1853 when journalist and statistician James D. B. DeBow became the director of the census 
(US Census Bureau 2015c). His census publication Statistical View of the United States (also known as the Compendium) of the 1850 census data was also the first to include a map (US Census Bureau 2015b). Until this time, "the perception [had been] that the human and physical geographies of the United States were relatively uncomplicated," but with the addition of more land, it was deemed intricate enough to need a visual aid (Dahmann 2015). Although his census reports examined socioeconomic information within five regions (New England, Middle, Southern, Northwestern, and Southwestern), the map was divided into four regions (Mississippi Valley, Pacific Slope, Gulf Slope, and Atlantic Slope) based on major draining systems (US Census Bureau 2015c).

This initial map did not rely on state boundaries to define regions, but DeBow reclassified them using only the three largest draining systems as the East, West, and Interior. He then separated those regions by northern and southern subsections contouring state and territory lines. Different regional classifications were used in assorted publications of 1850 and 1860 census data, including "Great Natural Divisions” (Northeastern States, Lowlands of the Atlantic Coast, Intermediate Region, Allegheny Region, Lower Mississippi Valley, Northwestern States, and Pacific Coast) for reporting mortality statistics based on groups of states or counties (US Census Bureau 2015c). However, maps were not published consistently along with data until the 1870 census when Francis A. Walker created the Statistical Atlas (Dahmann 2015). The US census had changed from a means of merely measuring the need of state Congressional representation to "a quantitative scientific accounting of numerous aspects of the nation's many human geographies"(Dahmann 2015).

Henry Gannett, geographer of the 1880-1900 US censuses, created new regional classifications for the 1880 census. However, these definitions were not conducive to comparing various censuses, so he modified the regions to divide along county lines (US Census Bureau 2015c). The maps produced during Gannett's leadership were the first to correlate with data results from the census (Bower 2010). Since 1910, the US census has used the same nine divisions (described below) with the addition of Hawaii and Alaska in the 1960 census (US Census Bureau 2015c).

The US Census Bureau's current regional definitions have been in use since 1910. There are four Census Regions split into nine Census Divisions (Geography 2015a; see Figure 1). The four regions are 1) Northeast, 2) Midwest, 3) South, and 4) West. The Northeast is divided into 
New England (Connecticut, Maine, Massachusetts, New Hampshire, Rhode Island, and Vermont) and the Mid-Atlantic (New Jersey, New York, and Pennsylvania). The Midwest (before June 1984 this was known as the North Central Region) is divided into East North Central (Illinois, Indiana, Michigan, Ohio, and Wisconsin) and West North Central (Iowa, Kansas, Minnesota, Missouri, Nebraska, North Dakota, and South Dakota). The South is divided into the South Atlantic (Delaware, Florida, Georgia, Maryland, North Carolina, South Carolina, Virginia, Washington D.C., and West Virginia), East South Central (Alabama, Kentucky, Mississippi, and Tennessee), and West South Central (Arkansas, Louisiana, Oklahoma, and Texas). The West is divided into the Mountain (Arizona, Colorado, Idaho, Montana, Nevada, New Mexico, Utah, and Wyoming) and the Pacific (Alaska, California, Hawaii, Oregon, and Washington).

It is important to note that the US Census Bureau regions lie along state borders, thus including entire states into their respective divisions. Moreover, since the regions are used for the US census, they only consist of the 50 states of America and do not include Puerto Rico, other US territories, Canada, or Mexico.

Woodard: American Nations: A History of the Eleven Rival Regional Cultures of North America Colin Woodard is a journalist and author who published American Nations: A History of the Eleven Rival Regional Cultures of North America in 2011. Woodard's theoretical distinctions of the US are based on the historical pattern of settlement by different cultural groups as they arrived and spread across North America (see Figure 2). For example, he describes the "Deep South" as the "center of the states' rights movement, racial segregation, and labor and environmental deregulation" that was settled by Barbados slave lords as an area spanning the eastern part of Texas eastward to the southern half of North Carolina and reaching south about three fourths of the state of Florida (Woodard 2011). Although Lieske (1993) points out that environmental conditions helped mold the establishment of regions as settlers had to adapt to their new surroundings and an article in the Washington Post by MacGillis (2011) agrees that Woodard (2011) also argued this point quite persuasively, one study has found Woodard's eleven nations do not seem to be quite distinct, at least by the cultural index of Hofstede (Mazanec et al. 2015). However, his focus on the cultural and historical backgrounds of these areas help may shed light on the mortality patterns of their residents today. 
Woodard's eleven nations include: 1) Yankeedom, 2) New Netherland, 3) The Midlands, 4) Tidewater, 5) Greater Appalachia, 6) Deep South, 7) El Norte, 8) The Left Coast, 9) The Far West, 10) New France, and 11) First Nation. Below is a brief summary of each nation along with a description on the Spanish Caribbean:

\section{Yankeedom}

Spanning the far eastern borders of the Dakotas, encompassing Minnesota, Wisconsin, and Michigan, past Lake Erie to New York through Maine and catching the tops of Illinois, Indiana, Ohio, and Pennsylvania, Yankeedom is an area of 441 counties that were originally settled by radical Calvinists. First settled by a few hundred Pilgrims in the 1620s, Yankeedom was soon controlled by the Puritans who arrived in the 1630s. These later founders attempted to create the ideal society through self-denial in order to serve the common good (5). They had a strong emphasis on education, community strength, and citizen participation in government in order to protect themselves against controlling outside powers along with strict religious rules that subjected offenders to severe punishments $(5,57-58)$.

New Netherland

A small area of only 24 counties that covers the northern half of New Jersey and the southern-most tip of New York and southwestern Connecticut, New Netherland encourages diversity and free trading. Settled by the Dutch in 1624, the values of the area are quite influential in the US's "media, publishing, fashion and intellectual and economic life" as Woodard points out that they greatly contributed to the liveliness, colorfulness, and strength of New York City $(6,65)$.

\section{The Midlands}

Settled by English Quakers in 1680s, these 465 counties found at the corners of Iowa, Nebraska, Kansas, and Missouri span in thin lines north to North Dakota, east to southern New Jersey, and southwest to the tip of Texas and lonely northeast corner of New Mexico (92). Residents are primarily and ethnic and ideologically diverse middle-class with contempt for government involvement and moderate to indifferent political views (6).

\section{Tidewater}

One hundred and forty-nine counties along the Eastern Seaboard in North Carolina, Virginia, Maryland, Delaware, and Washington D.C. make up Tidewater. This nation, settled naively by young English gentry and an assortment of vagabonds in 1607, is highly conservative 
with a strong "respect for authority and tradition," particularly in politics $(7,44)$. They are intolerant of equality and have been declining in their national influence, cultural unity, and land to the Midlands (8).

\section{Greater Appalachia}

As the largest of these nations with 922 counties, Greater Appalachia was founded by "bellicose settlers from the war-ravaged borderlands of Northern Ireland, northern England, and the Scottish lowlands" in the mid-1700s $(8,102)$. Filled with a "warrior ethic and deep commitment to individual liberty and personal sovereignty," these residents now find themselves stereotyped as "rednecks" or "hillbillies" (8). This nation consists of the heart of Texas and travels east to West Virginia, Virginia, and North Carolina while encompassing the area between the Midlands and the Deep South. It includes the whole of Kentucky and all but two counties of West Virginia along with large chunks of Tennessee and Oklahoma, the southern halves of Illinois, Indiana, and Ohio, and the northern tips of Mississippi, Alabama, Georgia, and South Carolina.

Deep South

These 501 counties were settled in 1670-1671 by Barbados slave lords and span the eastern part of Texas eastward to the southern half of North Carolina and reaching south about three fourths of the state of Florida (82). Woodard describes it as the "bastion of white supremacy, aristocratic privilege, and a version of classical Republicanism modeled on the slave states of the ancient world" (9). The Deep South was created as a replica of the horrific and brutal slave state that the founders came from due to its profitability $(82,83)$.

\section{El Norte}

El Norte's 87 counties include the southern-most counties of the US that border Mexico from Southern California to southeast Texas. They also have a brief jut northwards in New Mexico to central, southern Colorado. This mainly Hispanic nation is the "oldest of the EuroAmerican nations" as a "hybrid between Anglo- and Spanish America (10). It has the oldest European cultural influence as Spain discovered the Americas in 1492 and moved north (23-24). Spanish Americans have inhabited parts of El Norte, like northern New Mexico and southern Colorado, since 1595, and they vigilantly distinguish between their culture and that of the Mexican Americans who arrived in the 1800-1900s (24). It also sinks into Mexico, and is 
therefore divided in two by the growing military border between the countries (10). As such, residents would rather create a third nation on their own (10).

The Left Coast

The 54 counties of the Left Coast were settled in the late 1820s by New Englanders and a short while later were joined by those from Greater Appalachia-thus holding similar views on ideals and intelligence $(11,217-218)$. Spanning the west coast of Washington, Oregon, and northern California, these residents enjoy self-discovery while supporting the government and social reforms (11).

The Far West

This dry and remote land of 429 counties encompasses several large western states including Idaho, Nevada, Utah, Wyoming, and Montana while reaching into the centers of the states surrounding them. The vast amount of land needed transportation and other industrial resources, thus the government or other companies managed their construction from distant cities (12). However, many of the residents did not like the government interference (12).

\section{New France}

This small nation of 25 counties exclusively in Louisiana is a cultural blend of "northern French peasantry" and "northeastern North America" $(9,34)$. First settled as a nation exclusively in Canada in 1604, the founders created friendly relationships with the land's Native American nations, and later their Cajun descendants blended their Christian heritage with the Native Americans' religion in Louisiana $(35,39)$. They are motivated by the common good and are the most liberal people of North America (9).

\section{First Nation}

The First Nation is exclusively in Canada; therefore, it is not included in this proposal.

\section{Spanish Caribbean}

These 12 counties are exclusively in the southern tip of Florida. Similar to El Norte, this area was also mapped by the early Spanish settlers (23).

\section{Garreau: The Nine Nations of North America}

Joel Garreau, ${ }^{4}$ another journalist and scholar, published the book The Nine Nations of North America in 1981. He created these distinct nations based on the economic and political priorities and popular cultural values of the regions' inhabitants. According to Lieske (1993), he

\footnotetext{
${ }^{4}$ For more information, his personal website: http://www.garreau.com/index.cfm
} 
and Garreau conceived their regional nations in an attempt to eventually explain social behavior. Much like Murray's formulation of Eight Americas for grouping mortality trends, Garreau's regional classifications inspired a study where the authors created their own eight regions with similar economic backgrounds to better understand real estate portfolio efficiency (Hartzell, Shulman, and Wurtzebach 1987). They too found the previous literature's focus on four regions (i.e., Northeast, Midwest, West, and South) to be vague and ineffective (Hartzell, Shulman, and Wurtzebach 1987). However, Kahle (1986) found Garreau's Nine Nations were not significantly related to the cultural values of a probability sample of Americans. In fact, in this study the US Census Bureau's regions and divisions were better associated with their values (Kahle 1986). Additionally, Garreau's nations were created thirty years prior to the mortality data I will be examining; thus, putting the generality of his regional distinctions over time to the test.

Garreau's nine nations include: 1) New England, 2) The Foundry, 3) Dixie, 4) The Islands, 5) MexAmerica, 6) Ecotopia, 7) The Empty Quarter, 8) The Breadbasket, and 9) Quebec. He also includes a tenth chapter entitled "Aberrations," that includes Alaska, Hawaii, New York City, and Washington D.C. Garreau singled them out because they had conflicting characteristics that could fit them into several of the nations, but in our past analyses and this thesis New York City and Washington D.C. are included in the respective nations around them. Below is a brief summary of each nation:

New England

Garreau's version of New England is the same 66 counties as the US Census Bureau's New England with the exception of excluding Fairfield County, Connecticut. It includes all of Maine, Massachusetts, New Hampshire, Rhode Island, and Vermont along with the rest of Connecticut. He paints this nation as being highly educated, claiming to be the only civilized region in the US, but he points out that it is also the poorest (16). The residents have a strong commitment to self-discipline and conservation as they have few natural resources, but this is balanced with a strong public transportation system (9).

\section{The Foundry}

This nation consists of 426 counties that include all of New York, Delaware, Pennsylvania, New Jersey, Washington D.C., and Ohio along with large portions of Michigan, Indiana, and Maryland. It also extends shortly into Wisconsin, Virginia, and West Virginia. In the past, The Foundry was an important contributor to the industrialization of the US due to its 
wide array of waterways and ports; however, it has since decreased in its power $(2,58,60)$. Filled mainly with cities, its population values work as an "essential part of life" (75).

Dixie

Dixie has the most counties at 1,219, though its overall size is comparable to The Empty Quarter and The Breadbasket. This nation includes all of Arkansas, Louisiana, Kentucky, Tennessee, Mississippi, Alabama, Georgia, and the Carolinas with most of Virginia, West Virginia, Missouri, and Florida along with parts of west Texas, Oklahoma, Illinois, Indiana, and Maryland. It is also quite similar to the US Census Bureau's South region. Garreau emphasizes this nation's "unquestioning commitment to growth" as it is double the national average growth rate $(9,141)$. He notes this is a diverse hodgepodge of an area, but that it is a place of change (130-131). The residents appreciate getting to know one's neighbors (146).

\section{The Islands}

These seven southernmost counties in Florida are composed of mainly Cuban residents and are part of one of the world's largest trade industries with Latin America and other regions (176). However, Garreau notes that "drug-smuggling is South Florida's number one industry ahead of tourism" (169).

MexAmerica

MexAmerica, similar to Woodard's El Norte, consist of 141 counties bordering Mexico from Texas to Southern California with a short uptick in New Mexico to central Colorado. Similar to Dixie, MexAmerica is exhibiting a large amount of growth, both in people (mainly Hispanic) and wealth $(211,218)$. He thinks that it may supersede The Foundry in this respect as the "dominant region" (218). The nation is filled with important resources such as "water, power, and even breathable air" (4).

Ecotopia

This nation of 61 counties is found along the west coast of Washington, Oregon, and California, much like Woodard's Left Coast. It is filled with renewable-energy resources and residents who care about the environment and enjoying simple lives close to nature $(9,275)$. This nation is known for being open-minded and appreciating education (261). The Empty Quarter

The 236 counties of this vast nation encompass Idaho, Nevada, and Utah with the majority of Oregon, Washington, Montana, and Wyoming as well as parts of California, 
Colorado, New Mexico, and Arizona. Even though it makes up about a quarter of the US, it only has less than one-twenty-fifth of the continent's population (301). It has an abundance of minerals and coal deposits, and is the only area with places containing Quality One air $(3,302)$. The Empty Quarter is nearly identical to the US Census Bureau's West region, but is slightly smaller as its borders are enclosed by MexAmerica on the south, Ecotopia on the west, and the Breadbasket on the east.

\section{The Breadbasket}

This nation contains 953 counties that span the heart of the US completely including the Dakotas, Nebraska, Kansas, Minnesota, and Iowa as well as most of Oklahoma, Texas, Illinois, and Wisconsin. Garreau found this to be a nation that has a team mentality, perhaps because of its lack of diversity, but that it was a socially "calm" $(334)$ area $(339,350)$. Though it has quite the successful agricultural economy (331), outsiders find its residents are "behind the times and, for that matter, not too smart" (337).

Quebec

This nation is exclusively in Canada; therefore, it will be excluded from my analyses.

\section{Aberrations}

Garreau found that Alaska, Hawaii, New York City, and Washington D.C. had characteristics that would allow them to easily fit within several nations; therefore, he created this separate category. For this proposal, New York City and Washington D.C. will be located in the spatial nations within which they are embedded while Alaska and Hawaii will not be included.

Applying Regional Classifications to SeX-SPeCific Mortality Disparities Preliminary Findings

Previous research using census regions and divisions have produced mixed results. Kindig and Cheng (2013) found that female mortality rates were more affected by location using the four Census regions than male mortality rates; however, Wang and colleagues (2013) criticized their study and instead found that life expectancy improvements were similar by sex and location. Both studies recommended more nuanced approaches for examining the areas.

Preliminary findings suggest that Woodard's "American Nations" model predicts slightly more variation in county-level age-adjusted all-cause mortality for both 2007 (Myers et al. 2015) and 2010 (Cossman, Wolf, and Myers 2016a), including 2010 sex-specific rates (Wolf, 
Cossman, and Myers 2016; Cossman, Wolf, and Myers 2016b), than Garreau's nations or the US Census Bureau divisions when comparing base models without controls (see Table 1). For 2007 mortality, Woodard's classification had a greater adjusted $\mathrm{R}^{2}$ value $(0.25)$ than the US Census Bureau (0.21) and Garreau (0.21), indicating his "American Nations" had the best statistical fit (Myers et al., 2015). For 2010 mortality for the whole population, the adjusted $\mathrm{R}^{2}$ values were even higher across all classifications and Woodard's still remained the highest (Cossman, Wolf, and Myers 2016a). Model fits were marginally weaker with the division into sex-specific mortality for 2010, but again Woodard's were the best fit for both males and females. Woodard's "American Nations" were also found to outperform the other two classifications on predictions of sex-specific life expectancy for 2010 (Wolf, Cossman, and Myers 2016).

These preliminary analyses also took into account several mediator variables. The most recent and comparable of the previous studies included variables accounting for rurality, county dependency for production, hospital and doctor rates of availability, lack of health insurance, race, and sex-specific measures of education and indicators of obesity and physical activity (Cossman, Wolf, and Myers 2016b). Even with the inclusion of these other factors, Woodard's regional model remains supreme; albeit, only slightly so. For male mortality the adjusted $\mathrm{R}^{2 \text { 's }}$ were: 0.60 for Woodard; 0.59 for the US Census Bureau; 0.60 for Garreau; and for female mortality they were: 0.57 for Woodard; 0.54 for the US Census Bureau; 0.56 for Garreau (Cossman, Wolf, and Myers 2016b). Our most recent results also found that rurality via the Rural-Urban Continuum Codes (RUCCs) did not increase the models' explanatory power greatly (Cossman, Wolf, and Myers 2016b). What has continued to stand out across the sex-specific mortality studies has not been the relatively negligible difference among the regional classifications, but rather, the larger difference between male and female mortality predictions once mediating factors are considered. In other words, none of the models including additional variables work as well for females as they do for males.

This disparity between model fit for male and female mortality is what drove the decision to include health behavior elements here. A measure of tobacco use is crucial in understanding mortality, especially since cigarette smoking is the most preventable cause of death in the US and has been for decades (U.S. Department of Health and Human Services 2014). Even when accounting for confounding factors, the relationship between smoking and mortality is strong (Rogers et al. 2005). Montez and Zajacova (2013) also highlight the negative effects of smoking 
for women's mortality, particularly for those with less education, and recommend boosting work-family policies for women due to the large role employment plays in the mortality gap between high- and low-educated women. Adding these measures may augment the explanatory power of each of the models for female mortality.

\section{Hypotheses}

Based on preliminary findings, I generated four hypotheses. First, I hypothesize that Woodard's “American Nations" will continue to explain more variance in these new models predicting sex-specific mortality rates than the US Census Bureau's or Garreau's classifications; and the US Census Bureau's classifications will explain more variance than Garreau's 5 classifications. Second, with the addition of the measures on smoking and labor force participation that the new models will predict female and male mortality more equally (rather than as previously fitting better for males than females). Third, I compare the effects of the "people" (i.e., percent no health insurance, educational attainment, race, physical activity, obesity levels, smoking, and labor force participation) and "place" (i.e., regional classifications, RUCCs, typology, active MDs, hospital beds, Gini) predictors within models. While both play a role in mortality disparities, the literature has found that context (i.e., place) may explain more of these differences than individual behaviors (e.g., Kindig and Cheng 2013; Montez, Zajacova, and Hayward 2016). Therefore, I hypothesize that the "place" models will explain more variance in mortality than the "people" models. Finally, I expect Woodard's nations to better capture spatial variations in mortality than the other regional categorizations. The regions may be capturing the same mortality hot and cold spots of "healthy and unhealthy places," but due to Woodard's boundaries transcending state lines, his regions may be capturing slightly more of certain "clusters."

METHODS

Data

All data was downloaded at the county-level since Woodard and Garreau's regional classifications are delineated at this level. The US Census Bureau divisions can be examined at this level as well due to their state borders. The various sources that were used to collect the assortment of variables for these analyses are described below.

\footnotetext{
5 Another study has found Garreau's "Nine Nations" theory to perform less favorably against the US Census Bureau divisions in finding values (e.g., self-respect) related to those regions (Kahle 1986).
} 


\section{Dependent variables}

Mortality data from the CDC Wonder (Centers for Disease Control and Prevention 2016) database was used to explore how well these regions explain sex-specific differences in ageadjusted all-cause mortality rates centered on 2010. Calculating a five-year rate centered on 2010 reduces the possibility of an unusually high number of deaths in a county (e.g., from a large accident) skewing the calculation. I requested age-adjusted mortality rates per 100,000 for males and females from CDC Wonder. Mortality rates for counties with less than 10 deaths were marked by CDC Wonder as unreliable along with those where the numerator was 20 or less; any county with data marked as unreliable was dropped (along with those in Alaska and Hawaii) leaving a total of 3,076 counties.

\section{Mediators}

Mediator data was from 2000 or 2001 in order to account for lag time between factors and their potential effects on mortality. I used data gathered from the Area Health Resource File (AHRF 2012); it includes each county's 2003 RUCC (ranging from 1 to 9) ("USDA ERS Rural-Urban Continuum Codes” 2016) and 2004 typology (i.e., farming, mining, manufacturing, government, or service dependent; reference is nonspecialized-dependent) (“USDA ERS County Typology Codes" 2017). Similarly to Kindig and Cheng (2013), I used the AHRF's rates of active MDs and hospital beds per county along with the percents of those with no health insurance, as well as the AHRF's sex-specific racial composition of the county (i.e., white, black, other) from the year 2000. The US Census Bureau (2016a) has data providing the 2000 Gini coefficient for each county, used as a measure of income inequality similar to Ezzati and colleagues (2008).

Independent variables also included the rates of sex-specific educational attainment (US Census Bureau 2016a) and sex-specific percents of obesity and physical activity per county (Institute for Health Metrics and Evaluation n.d.). Dwyer-Lindgren and colleagues (2013) noted that both obesity and physical inactivity are associated with premature death, and their study

\footnotetext{
${ }^{6}$ Rural-Urban Continuum Code descriptions: (1) county in metro area with 1 million population or more; (2) county in metro area of 250,000 to 1 million population; (3) county in metro area of fewer than 250,000 population; (4) nonmetro county with urban population of 20,000 or more, adjacent to a metro area; (5) nonmetro county with urban population of 20,000 or more, not adjacent to a metro area; (6) nonmetro county with urban population of 2,50019,999 , adjacent to a metro area; (7) nonmetro county with urban population of 2,500-19,999, not adjacent to a metro area; (8) nonmetro county completely rural or less than 2,500 urban population, adjacent to metro area; (9) nonmetro county completely rural or less than 2,500 urban population, not adjacent to metro area ("USDA ERS Rural-Urban Continuum Codes" 2016).
} 
found that county-level measures of both are not highly correlated with one another. I used these measures to capture more individualistic components of the population as opposed to the contextual components of rurality or hospital doctor/bed availability. Data on educational attainment from the US Census Bureau (2016) was available for those over the age of 25 for a variety of levels, from no schooling to the doctorate level; I combined them into three categories: (1) less than high school, including no schooling; (2) high school graduate (includes equivalent) to associate degree; (3) bachelors degree to doctoral degree.

The data on obesity and physical activity levels was from 2001. Dwyer-Lindgren and colleagues (2013) explain how they used body mass index (BMI) reports of respondents from the Behavioral Risk Factor Surveillance System (BRFSS) and modified the responses by taking into account self-reported bias via the National Health and Nutrition Examination Survey (NHANES) to calculate county-level measurements of obesity (i.e., BMI $\geq 30$ ) with "validated small area estimation methods" (1). Similarly, self-reported BRFSS data was used to calculate the prevalence of sufficient ${ }^{7}$ levels of physical activity with the small area estimation methods (Dwyer-Lindgren et al. 2013).

Additionally, I downloaded county-level, sex-specific smoking behavior data from the Institute for Health Metrics and Evaluation (Institute for Health Metrics and Evaluation 2016). They used BRFSS data to calculate rates for counties and county equivalents ${ }^{8}$ (Dwyer-Lindgren et al. 2014). The data spans from 1996 to 2012; I used the 2000 data to be consistent with the other mediator variables. This data indicated the percent of people who currently smoke daily per county. Labor force participation data from the 2000 US Census (US Census Bureau 2016b) measures by sex the number of individuals over the age 16 in the labor force (i.e., employed, unemployed, Armed Forces) or not in the labor force per county. I created unemployment rates as the proportion of those who are unemployed divided by those in the labor force times 1,000. After removing counties that were missing any of the mediator variables, the final sample consisted of 3,070 counties.

\footnotetext{
7 “Sufficient physical activity is defined as reporting 150 total minutes of moderate activity per week, the equivalent in vigorous activity, or combination of moderate and vigorous activity ( 1 minute vigorous activity $=2$ minutes moderate activity)" (Dwyer-Lindgren et al. 2013).

${ }^{8}$ For males and females, the researchers had combined the daily smoking means of the following counties: Adams, $\mathrm{CO}$; Boulder, CO; Broomsfield, $\mathrm{CO}$ (not included in analyses); Jefferson, CO; and Weld CO; for my analyses I used the same daily mean value for each county individually. The same approach was taken with the combined Southampton, VA and Franklin City, VA along with Prince William, VA and Manassas Park City, VA.
} 


\section{Regional Classifications}

The main variable of interest is the regional classification in each model. I compared the US Census Bureau Divisions, Woodard's “American Nations" (2011), and Garreau's "Nine Nations" (1981). The US Census Bureau Divisions consist of: 1) New England (ref); 2) Mid Atlantic; 3) East North Central; 4) West North Central; 5) South Atlantic; 6) East South Central; 7) West South Central; 8) Mountain; and 9) Pacific. Woodard's “American Nations" (2011) consist of: 1) Yankeedom (ref); 2) Deep South; 3) El Norte; 4) Far West; 5) Greater Appalachia; 6) Left Coast; 7) Midlands; 8) New France; 9) New Netherlands; 10) Spanish Caribbean; and 11) Tidewater. Garreau's "Nine Nations" (1981) consist of: 1) New England (ref); 2) The Empty Quarter; 3) Ecotopia; 4) The Breadbasket; 5) MexAmerica; 6) The Foundry; 7) Dixie; and 8) The Islands.

Analyses

Descriptive tables detailing the individual divisions and nations for each classification scheme and the appropriate measure of each control variable (e.g., see sample Table 2) provide a clear summary of the characteristics of each division and nation. Standardized ordinary least squares (OLS) regressions of the sex-specific, age-adjusted, all-cause 2010 mortality rates on the mediators and each of the three regional classifications are presented across five models. First, base models analyze the effect of each classification on the mortality rates. A second set of models include the regional classifications along with the county mediators that indicate the "place" of the county (i.e., RUCCs, typology, active MDs, hospital beds, Gini). A third set of models include the "people" characteristics of the counties (i.e., percent no health insurance, educational attainment, race, physical activity, obesity levels, smoking, and labor force participation). These two models will be compared via adjusted $\mathrm{R}^{2}$ s, AICs, and BICs to answer the third hypothesis regarding the explanatory power of "people" versus "place" variables. A fourth set of models include all the variables from the second and third set of models (i.e., regional classifications, "place," and "people"), with the exception of the smoking and labor force participation variables, serving as the comparison for the new (fifth) full set of models. A fifth set of models include the variables in the fourth set of models and the newly acquired data on smoking and labor force participation, used to answer two hypotheses: 1) whether or not Woodard's classification models are the best fit; 2) whether or not the explanatory power for female mortality is more equitable to that of the male mortality. These final models also are a 
combination of models two and three, allowing me to compare the relative strength of each "people" and "place" indicator via their standardized beta values to further address the third hypothesis.

Standardized coefficients permit comparison of the relative effect each control variable has on mortality rates; adjusted $\mathrm{R}^{2 \text { ' }} \mathrm{s}$ will allow me to compare model fits across classifications. Data management (i.e., merging data sets) was conducted in SPSS 23 and 24 while data analyses were performed in Stata 13.

Maps

I created visual representations of the sex-specific mortality rates across the country using ArcMap 10.4, specifically choropleth maps illustrate the three regional classifications and the mortality rates in each county. Choropleth maps will be used since the data is at the county-level and they are favorable for visually demonstrating various levels of mortality. Lighter counties represent lower death rates and darker counties represent higher death rates.

First, I created three maps - one for each regional classification; then I created six maps - three for male mortality and three for female mortality, each outlining one of the three regional classifications. Two final maps - one for male mortality and one for female mortalityoutline all three of the regional classifications, to show if common hot or cold spots of high or low mortality (i.e., "healthy and unhealthy places") are present fully in individual regions. In other words, this map will answer the fourth hypothesis by showing if the similarities in previous models (Cossman, Wolf, and Myers 2016b; Cossman, Wolf, and Myers 2016a; Wolf, Cossman, and Myers 2016) are due to overlapping of regions on the same clusters of low or high mortality while also covering different average areas of mortality.

\section{RESULTS}

\section{Descriptives}

Tables 3a-3c illustrate the descriptive statistics for the US Census Bureau's divisions (henceforth, census divisions). New England has the lowest average female mortality rate and the second lowest male mortality rate. Expectedly, it consistently demonstrates a high ranking compared to other divisions in factors considered to lower mortality risk while also ranking low in factors considered to increase one's risk of mortality. For example, New England counties have some of the highest average percent of residents with a bachelor's degree or higher, of those who reach sufficient physical activity levels, of active MDs, and of white residents, while 
also containing the lowest unemployment rates for males and females, obesity levels, residents who smoke daily, and uninsured residents. New England does have some of the fewest hospital beds per 1,000 residents while having one of the largest populations. Additionally, New England is mainly urban and has the highest average number of service-dependent counties. The Pacific division has the lowest average mortality rates for males and the second lowest for females. It ranks lower than most other divisions in its average percent of obese males, percent of daily smokers, percent black residents, and in hospital bed rates while ranking among the highest in residents with a bachelor's degree or higher, sufficient physical activity levels, and overall population size. However, it falls in between the other nations regarding active MDs, Gini, percent white residents, and has relatively high levels of uninsured residents and female unemployment.

East South Central has the highest average mortality levels for both sexes followed by West South Central and South Atlantic. All three of them rank high for percent of residents who are obese and low in sufficient physical activity levels. East South Central and South Atlantic both rank high in their percent of black residents and percent of residents who smoke daily while ranking low in percent of white residents. East South Central and West South Central both rank high in unemployment rates for females and Gini and low in active MD rates. East South Central also ranks high with percent of residents with less than a high school degree, unemployment rates for males, and manufacturing-dependent counties while having one of the lowest overall populations. West South Central also ranks highly in the percent of uninsured residents. While most divisions were consistent for both sexes on each factor, unemployment rates tended to differ more depending on sex and division.

Tables 4a-4c illustrate the descriptive statistics for Woodard's "American Nations" (henceforth, Woodard's nations). New Netherlands has the lowest average mortality rates followed by the Spanish Caribbean and the Left Coast. Expectedly, New Netherlands consistently demonstrates a high ranking compared to other divisions in factors considered to lower mortality risk while also ranking low in factors that are considered to increase one's risk of mortality. For example, New Netherlands counties have some of the highest average percent of residents with a bachelor's degree or higher, of active MDs, and of service-dependent counties while also containing the lowest obesity levels, residents who smoke daily, and uninsured residents. However, New Netherlands does have one of the highest Gini scores and one of the 
largest populations. Oddly, the Spanish Caribbean only ranks high amongst the nations in obesity and Gini, despite having the second lowest average mortality rates. Similarly, the Left Coast has a high unemployment rate for males and the lowest hospital bed rates, but has an incredibly low Gini score, higher levels of physical activity, and is mainly urban. Yankeedom, the reference category in the models below, has the fourth lowest mortality rates along with the lowest average percent of residents who are uninsured per county, one of the highest percentage of white residents, and is mainly manufacturing-dependent.

The Deep South, New France, and Greater Appalachia have the highest average mortality levels, respectively; they also rank highest among the nations with residents who smoke daily. The Deep South ranks high among the nations with its average percent of uninsured, obese, and black residents along with a high average Gini score. It ranks amongst the lowest with white residents and those who reach sufficient physical activity levels. New France also ranks high with obesity levels and Gini, but has the second highest level of female unemployment as well. New France also ranks low in sufficient physical activity and is a mainly mining- and nonspecialized-dependent nation.

Tables 5a-5c illustrate the descriptive statistics for Garreau's "Nine Nations" (henceforth, Garreau's nations). The Islands nation has the lowest mortality rates. For males, Ecotopia and New England had the next lowest rates; for females, New England and MexAmerica did. The Islands ranks higher in both percent of residents with less than a high school education and of those with greater than a bachelor's degree, has the highest Gini score and population while being mainly service-dependent. New England is a mainly urban nation that has the highest average percent of residents with a bachelor's degree or higher, active MDs, and residents who are white while ranking low among those who are uninsured and obese. Ecotopia is also mainly urban and nonspecialized-dependent while having both the highest average unemployment rate for males and percent of residents attainting sufficient physical activity. MexAmerica has a high average percent of less than high school educated residents, unemployed females, and uninsured residents while also ranking low on hospital bed rates and residents who smoke daily.

Dixie has the highest mortality levels for males and females. It also has the highest average obesity levels, percent of residents who smoke daily, percent of black residents, and percent of residents with less than a high school education, and the lowest average percent of 
percent of white residents and residents who reach sufficient physical activity levels. Dixie also ranks high on unemployment rates for both sexes.

Model $1 \mathrm{a}$ and $1 \mathrm{~b}$ : Male and Female Mortality without Mediators

In the first set of models, I regress male and female mortality on the three regional classifications. Model 1a (Table 6) shows the results for male mortality and Model 1b (Table 7) shows the results for female mortality. Both models reveal that Woodard's nations are the best fit as indicated by the highest adjusted $\mathrm{R}^{2}$ (male: 0.3256; female: 0.3300) and lowest AIC (male: 39,063; female: 36,874) and BIC (male: 39,129; female: 36,940) scores. The two models also show that Garreau's nations) is the worst fitting classification as indicated by the lowest adjusted $\mathrm{R}^{2}$ (male: 0.2954; female: 0.2686) and highest AIC (male: 39,194; female: 37,140) and BIC (male: 39,242; female: 37,189) scores - as such, the following results and discussion will focus mainly on Woodard's nations and the census divisions. The census divisions predict $2.23 \%$ less of male mortality and 3.58\% less of female mortality than Woodard's nations.

Seven of Woodard's nations predict significantly different male mortality levels from the reference group of Yankeedom $(p<0.01)$; five of them predict higher levels while the Left Coast and New Netherlands predict lower levels. Seven of Woodard's nations predict significantly different female levels of mortality from Yankeedom as well; however, in this case Far West is a significantly higher predictor while the Left Coast is not significant. El Norte and the Spanish Caribbean are not significantly different from Yankeedom for either sex. For males and females, Greater Appalachia (male: beta=0.524; female: beta=0.562) and Deep South (male: beta=0.517; female: beta $=0.506$ ) are the strongest relative predictors - both indicating much higher levels of mortality than Yankeedom.

Six of the census divisions predict significantly different male mortality levels from the reference group of New England ( $p<0.001)$; all of them predict higher levels. Each of those census divisions also predicts significantly higher levels of female mortality from New England with the addition of the Mountain division as well. The Pacific division is not significantly different from New England for either sex. For males and females, East South Central (male: beta $=0.602$; female: beta $=0.589$ ), West South Central (male: beta $=0.409$; female: beta $=0.453$ ), and South Atlantic (male: beta $=0.403$; female: beta=0.416) are the strongest relative predictorsall indicating much higher levels of mortality than New England. These three divisions overlap considerably with Greater Appalachia and the Deep South except for the southern halves of 
several northeastern states and the inclusion of several full eastern states.

Four of Garreau's nations predict significantly different male mortality levels from the reference group of New England $(p<0.01)$; three of them predict higher levels while The Islands predicts lower levels. The same four predict significantly different female levels of mortality from New England as well; however, in this case The Empty Quarter is also a significantly higher predictor. Ecotopia and MexAmerica are not significantly different from New England for either sex. For males and females, Dixie (male: beta $=0.684$; female: beta $=0.689$ ), the Breadbasket (male: beta $=0.188$; female: beta $=0.198$ ), and The Foundry (male: beta $=0.160$; female: beta $=0.186$ ) are the strongest relative predictors - each indicating higher levels of mortality than New England.

\section{Model $2 a$ and 2b: Male and Female Mortality with "Place" Mediators}

Male Model 2a (Table 8) and female Model 2b (Table 9) show the results of regressing mortality rates on the three regional classifications and several "place" mediator variables. These "place" variables include RUCCs, economic typology, two medical care factors (i.e., active MD and hospital bed rates), and the Gini inequality index. The final column shows the model without a regional classification, but with all the "place" mediators.

The male models (Model 2a) show that Garreau's nations is the best fit as indicated by the highest adjusted $\mathrm{R}^{2}(0.4474)$ and lowest AIC $(38,464)$ and BIC $(38,609)$ scores; however, it predicts less than $0.5 \%$ more than Woodard's nations' model. Of the three models including regional classifications, the census divisions provide the worst fitting model as indicated by the lowest adjusted $\mathrm{R}^{2}(0.4305)$ and highest AIC $(38,557)$ and BIC $(38,708)$ scores. However, the model without a regional classification has a much lower score in fit as it explains only $31 \%$ of male mortality rates. This finding indicates that regions are important factors in predicting male mortality when also considering "place" factors.

Gini was one of the strongest predictors in Model 2a. For the census divisions, as counties' Gini index increases, mortality rates significantly increase $(p<0.001)$; Gini (beta $=0.287$ ) is the second strongest predictor in the model behind being a county in East South Central (beta=0.390). In Woodard's model, Greater Appalachia (beta=0.377) and the Deep South (beta $=0.345$ ) are the strongest predictors while Gini is the third strongest (beta $=0.294$ ). Dixie (beta $=0.399$ ) is Garreau's strongest predictor, followed by Gini (beta $=0.317$ ). 
The female mortality models (Model 2b) show that Woodard's nations is the best fit as indicated by the highest adjusted $\mathrm{R}^{2}(0.305)$ and lowest $\mathrm{AIC}(36,391)$ and $\mathrm{BIC}(36,554)$ scores; Woodard predicts $2.1 \%$ more than Garreau and 3.1\% more than the census divisions. Of the three models including regional classifications, the census divisions provide the worst fitting model as indicated by the lowest adjusted $\mathrm{R}^{2}(0.3996)$ and highest AIC $(36,552)$ and BIC $(36,702)$ scores. However, the model without a regional classification again has a much lower score in fit as it explains only $28.3 \%$ of female mortality rates. This finding indicates that regions are also important factors in predicting female mortality.

The census divisions Model $2 \mathrm{~b}$ is similar in significance, direction, and strength as census divisions Model 2a with the main exceptions being that South Atlantic (beta=0.269) and West South Central (beta=0.250) are also stronger predictors of female mortality than Gini (beta $=0.232$ ) instead of just East South Central (beta=0.398); Model 2a for census divisions explained $43.1 \%$ of male mortality, but its Model $2 \mathrm{~b}$ only explains $40.0 \%$ of female mortality. Woodard's Model 2b shares the same strongest predictors as Model 2a. Overall, Woodard's Model 2b explains $1.3 \%$ less than his Model 2a, but it is the best fit of the Model $2 \mathrm{~b}$ models. Garreau's model explains 2.1\% less than Woodard's in Model 2b, but explained the most variation by $0.4 \%$ more than Woodard in Model 2a.

Model $3 a$ and $3 b$ : Male and Female Mortality with "People" Mediators

Male Model 3a (Table 10) and female Model 3b (Table 11) regress mortality rates on the three regional classifications and several "people" mediator variables. These "people" variables include one medical care factor (i.e., percent without health insurance), and several sex-specific factors including measures on education, racial composition, three health indicators (i.e., obesity, physical activity, and smoking), and unemployment rates of those applicable to participate in the labor force. The final column shows the model run without a regional classification, but with all the "people" mediators.

The male models (Model 3a) show that Woodard's nations is the best fit as indicated by the highest adjusted $\mathrm{R}^{2}(0.6335)$ and lowest $\mathrm{AIC}(37,200)$ and $\mathrm{BIC}(37,320)$ scores; however, it predicts less than $0.7 \%$ more than the census divisions' model. Of the three models including regional classifications, Garreau's nations provide the worst fitting model as indicated by the lowest adjusted $\mathrm{R}^{2}(0.6210)$ and highest AIC $(37,299)$ and BIC $(37,402)$ scores. However, the model without a regional classification is roughly equivalent in fit as it explains $61 \%$ of male 
mortality rates. This finding indicates that regions are not quite as important factors in predicting male mortality when other "people" indicators are accounted for in the model, or that these "people" factors are mediating the relationship between regions and mortality. In the regional models, obesity $(p<0.01)$ and smoking $(p<0.001)$ both significantly and strongly predict higher levels of mortality with smoking as the highest predictor in each model.

The model without regions, but with the "people" mediators, found that the percent of those without health insurance (beta $=0.172 ; p<0.001$ ) and unemployment rates (beta=0.106; $p<0.001)$ are positive significant predictors of male mortality rates and are both relatively strong predictors. Increases in the percent of those in the county having either high school/some college (beta $=0.094 ; p<0.001$ ) or four or more years of college (beta $=0.123 ; p<0.001)$ both indicate significantly higher levels of mortality than the reference group of less than a high school education. As the percent of those who are white in the county increases, mortality rates significantly decrease compared to the percent of "other" races (beta $=-0.136 ; p<0.001$ ); however, this model is only on in Model 3a where the percent of black residents is significantit indicates higher mortality levels than "other" races (beta $=0.084 ; p<0.05)$. An increase in sufficient physical activity predicts lower levels of mortality as the second strongest predictor in this model of Model 3a (beta $=-0.201 ; p<0.001$ ). Obesity (beta=0.086; $p<0.001$ ) and smoking (beta $=0.507 ; p<0.001$ ) both significantly predict higher levels of mortality; smoking is the highest predictor in the model.

Compared to the model with place mediators but no regions (Model 2a), the model people controls and no regions (Model 3a) explains 29.7\% more of the male mortality rates. This indicates that the "people" mediators predict more of the variation in male mortality rates than the "place" mediators; this holds for models including any regional classification in Model 2a as well. Garreau's model was the best fit in Model 2a; however, the model with no regions in Model 3a explains $16.0 \%$ more of the male mortality rates than the "place" indicators plus Garreau's nations.

Similar to the male models, the female models (Model 3b) show that Woodard's nations is the best fit as indicated by the highest adjusted $\mathrm{R}^{2}(0.6094)$ and lowest AIC $(35,227)$ and BIC $(35,347)$ scores; however, it predicts about $0.3 \%$ more than the census divisions' model. Of the three models including regional classifications, Garreau's nations provide the worst fitting model as indicated by the lowest adjusted $\mathrm{R}^{2}(0.5913)$ and highest AIC $(35,363)$ and BIC $(35,465)$ 
scores. However, the model without a regional classification is roughly equivalent in fit as it explains $58.0 \%$ of female mortality rates. As with the male models, regions are not quite as important factors in predicting female mortality when other "people" indicators are accounted for in the model. Again, obesity $(p<0.05)$ and smoking $(p<0.001)$ both significantly and strongly (though obesity is not as strong in Garreau's model) predict higher levels of mortality with smoking as the highest predictor in each model.

The "people" model without regions found that the percent of those without health insurance (beta $=0.104 ; p<0.001$ ) and unemployment rates (beta=0.103; $p<0.001$ ) are positive significant predictors of female mortality rates and are both relatively strong predictors, though lack of health insurance is stronger here than in the census divisions' Model 3b. Neither measure of education is significantly different than the reference group of less than a high school education. As the percent of those who are white in the county increases, mortality rates significantly decrease compared to the percent of "other" races (beta $=-0.235 ; p<0.001)$; however, this model is only one in Model 3b where the percent of black residents is not significant - this is the opposite of the pattern in Model 3a where only the 'no regions' model had significance for the percent of black residents per county on mortality. An increase in sufficient physical activity predicts lower levels of mortality as the second strongest predictor in this model of Model 3b (beta $=-0.281 ; p<0.001)$. This is the only model in Model 3a or 3b where obesity is not a significant predictor of mortality. Smoking significantly predicts higher levels of mortality, as the strongest predictor in the model (beta $=0.436 ; p<0.001$ ).

As with the male models, compared to the model with no regions in Model 2b, the model with no regions in Model 3b explains $29.7 \%$ more of the female mortality rates. This indicates that the "people" mediators predict more of the variation in female mortality rates than the "place" mediators; this holds for models including any regional classification in Model $2 \mathrm{~b}$ as well. Woodard's model was the best fit in Model 2b; however, the model with no regions in Model $3 \mathrm{~b}$ explains $14.9 \%$ more of the male mortality rates than the "place" indicators plus Woodard's nations.

Model $4 a$ and 4b: Male and Female Mortality with Mediators (except Smoking and Labor Force Participation)

Male Model 4a (Table 12) and female Model 4b (Table 13) regress mortality rates on the three regional classifications, the "place" mediators, and several "people" mediator variables. 
These "people" variables include one medical care factor (i.e., percent without health insurance), and several sex-specific factors including measures on education, racial composition, and two health indicators (i.e., obesity and physical activity). Smoking and labor force participation were withheld from these models to mimic previous findings with a slight change with new data (i.e., the inclusion of sex-specific racial composition rather than a non-sex-specific variable). The final column shows the model without a regional classification, but with the same mediators.

The male models (Model 4a) show that Woodard's nations is the best fit as indicated by the highest adjusted $\mathrm{R}^{2}(0.6103)$ and lowest AIC $(37,401)$ and BIC $(37,606)$ scores; however, it predicts less than $0.4 \%$ more than the Garreau's nations' model — in fact, according to the BIC, Woodard's model fit is not more appropriate and parsimonious than Garreau's. The census divisions provide the worst fitting model, barely, as indicated by the lowest adjusted $\mathrm{R}^{2}(0.6022)$ and highest AIC $(37,463)$ and BIC $(37,656)$ scores. However, each of these models show lower fit than their counterparts in Model 3a, indicating that smoking and/or labor force participation are important omitted variables from these models since models that include them are better at explaining variation in male mortality.

Across the models, as the percent of those who are white $(p<0.001)$ or black $(p<0.001)$ in the county increases, mortality rates significantly decrease compared to the percent of "other" races; these represent two of the strongest predictors in each model. For the census divisions, an increase in sufficient physical activity significantly predicts lower levels of mortality as the second strongest predictor in the census Model 4a (beta $=-0.239 ; p<0.001$ ). Woodard's Greater Appalachia (beta $=0.251 ; p<0.001$ ) and Deep South (beta $=0.145 ; p<0.001$ ) are two of the strongest predictors in its model. An increase in sufficient physical activity significantly predicts lower levels of mortality as the third strongest predictor in Woodard's nations' Model 4a (beta= 0.246; $p<0.001$ ). For Garreau, Dixie was the strongest predictor of male mortality in Model 1a and Model 2a, but loses its significance in Model 4a. An increase in sufficient physical activity predicts lower levels of mortality as the strongest predictor in Garreau's nations' Model 4a (beta $=-0.285 ; p<0.001$ ).

Similar to the male models, the female models (Model 4b) show that Woodard's nations is the best fit as indicated by the highest adjusted $\mathrm{R}^{2}(0.5848)$ and lowest AIC $(35,428)$ and BIC $(35,633)$ scores; however, it predicts only about $0.9 \%$ more than Garreau's nations' model. The census divisions provide the worst fitting model as indicated by the lowest adjusted $\mathrm{R}^{2}(0.5653)$ 
and highest AIC $(35,567)$ and BIC $(35,760)$ scores. However, as with the male models, each of these models shows lower fit than their counterparts in Model 3b. This finding indicates that smoking and/or labor force participation are important omitted variables from these models since models that include them are better at explaining variation in female mortality as well.

Within each model again, as the percent of those who are white $(p<0.001)$ or black $(p<0.001)$ in the county increases, mortality rates significantly decrease compared to the percent of "other" races; these represent two of the second strongest predictors in each model. An increase in sufficient physical activity significantly predicts lower levels of mortality as one of the strongest predictors in each model as well $(p<0.001)$. In the census model, South Atlantic and West South Central are no longer significant, despite being two of the strongest predictors of female mortality in Models 1b, 2b, and 3b. Woodard's New France also loses significance despite being a relatively strong predictor in Model 1b. Greater Appalachia (beta=0.226; $p<0.001$ ) and the Deep South (beta=0.168; $p<0.001$ ) remain two of the strongest predictors in the model. In Garreau's model, Dixie is no longer significant despite having been the strongest regional predictor of female mortality in Model 1b, Model 2b, and Model 3b.

Woodard and Garreau's nations explain roughly the same amount of variation in male mortality (Model 4a), both more so than the census divisions, while Woodard's is the best fit of the three regional classifications for female mortality (Model 4B). However, even with more mediators than Models $3 \mathrm{a}$ and $3 \mathrm{~b}$, these models that omit smoking behaviors and labor force participation do not explain as much variation in mortality for either sex. This finding indicates the importance of these two variables; but, as will be described in the following sections, smoking behavior is most likely the factor driving these higher model fits.

\section{Model $5 a$ and 5b: Male and Female Mortality with All Mediators}

Male (Model 5a, Table 14) and female (Model 5b Table 15) mortality rates are regressed on the three regional classifications, along with the "place" and all "people" mediator variables. Smoking and labor force participation were added to the previous models to create these full models for this study. Woodard's nations is the best fit for male mortality (Model 5a) as indicated by the highest adjusted $\mathrm{R}^{2}(0.6487)$ and lowest $\mathrm{AIC}(37,085)$ and $\mathrm{BIC}(37,302)$ scores; however, it predicts only about $0.5 \%$ more than the census divisions' model and $0.8 \%$ more than Garreau's nations' model. Garreau's nations provide the worst fitting model, but not by much, as indicated by the lowest adjusted $\mathrm{R}^{2}(0.6410)$ and highest AIC $(37,149)$ and $\operatorname{BIC}(37,348)$ 
scores. Each of these models only have slightly higher fits than their counterparts in Model 3a; Woodard's fits only $1.5 \%$ better, the census is $1.7 \%$ better, and Garreau's is $2.0 \%$ better. This finding indicates that adding "place" variables to Model 3a does not change the fit of the model by much. The addition of Woodard's nations and the other "place" variables only improve upon the model in Model 3a with no regions by 4.1\%. Looking at this impact another way, by adding all of the "people" variables to Model 2a, each regional classification explains approximately $20 \%$ more variance in male mortality than with the "place" mediators alone (improvements: $21.3 \%$ for census, $20.5 \%$ for Woodard, $19.4 \%$ for Garreau).

Similar to Model 3a, smoking is the strongest predictor of male mortality within each model $(p<0.001)$. An increase in the percent of those without health insurance is one of the strongest predictors of an increase in mortality (particularly for Garreau) while an increase in the percent of those who are white or who reach sufficient physical activity levels strongly predicts a decrease in mortality $(p<0.001)$. The percent of black residents in the county is not a significant predictor for any of the regional models; this is interesting as this mediator was one of the strongest predictors in Model 4a. Gini and the percent of those with a high school degree or some college (compared to less than a high school degree) are two relatively strong positive predictors of mortality $(p<0.001)$.

In the census model, West North Central is the strongest regional predictor of mortality (beta $=-0.141 ; p<0.001)$. Greater Appalachia (beta=0.197; $p<0.001$ ) and the Deep South (beta $=0.148 ; p<0.001$ ) remain two of the strongest predictors in the model for Woodard's nations. For Garreau, Dixie is again no longer significant. As with Model 3a and Model 4a, the Breadbasket (beta $=-0.141 ; p<0.001)$, MexAmerica (beta $=-0.121 ; p<0.001$ ), and the Empty Quarter (beta $=-0.104 ; p<0.001)$ are the strongest regional predictors in the model.

Similar to the male models, the female models (Model 5b) show that Woodard's nations is the best fit as indicated by the highest adjusted $\mathrm{R}^{2}(0.6229)$ and lowest AIC $(35,134)$ and BIC $(35,351)$ scores; however, it predicts only about $0.6 \%$ more than the census divisions' model. Garreau's nations provide the worst fitting model as indicated by the lowest adjusted $\mathrm{R}^{2}(0.6089)$ and highest AIC $(35,243)$ and BIC $(35,442)$ scores. As with the male models, each of these models only have slightly higher fits than their counterparts in Model 3b, indicating that adding "place" variables to Model 3b does not change the fit of the model by much. The addition of Woodard's nations and the other "place" variables only improve upon the model in Model 3b 
with no regions by $4.3 \%$. In other words, by adding all of the "people" variables to Model $2 \mathrm{~b}$, each regional classification explains approximately $20 \%$ more variance in male mortality than with the "place" mediators alone (improvements: $21.8 \%$ for census, $19.2 \%$ for Woodard, 19.9\% for Garreau).

Similar to Model 3a, smoking is the strongest predictor of female mortality within each model $(p<0.001)$. An increase in the percent of those without health insurance is only a particularly strong predictor of an increase in mortality for Garreau while an increase in the percent of those who are white or who reach sufficient physical activity levels strongly predicts a decrease in mortality for each model $(p<0.001)$. Unlike Model 5a, the percent of black residents in the county is a strong significant predictor of lower mortality rates for each of the regional models. Also unlike Model 5a, Gini and the percent of those with a high school degree or some college (compared to less than a high school degree) are two relatively weaker positive predictors of mortality $(p<0.001)^{9}$; rather, obesity is a relatively strong positive predictor for census divisions and Woodard $(p<0.001)$, but less so for Garreau $(p<0.01)$.

In the census model, West South Central and East South Central are the strongest regional predictors of higher mortality $(p<0.001)$. Greater Appalachia (beta $=0.207 ; p<0.001$ ) and the Deep South (beta $=0.180 ; p<0.001$ ) remain two of the strongest predictors in the model for Woodard's nations. For Garreau, Dixie is again no longer significant. MexAmerica (beta= $-0.108 ; p<0.001)$ is the strongest regional predictor in the model.

Model 5a and 5b indicate that Woodard's nations explain more variation in male and female mortality than the other two regional classifications, though the difference is slight. Woodard explains less than $1.0 \%$ more variation in mortality than the census divisions for either sex. Overall, these full models have the best fit, but the only outperform their respective "people" models by $2.0 \%$ or less. In fact, these models outperform their respective "people" models with no regional classifications by less than $4.5 \%$. For both male and female mortality rates, "people" mediators are more important for predicting variation in mortality rates than the "place" mediators or regional classifications. The percent of people who smoke daily is a consistently important factor in predicting mortality rates. ${ }^{10}$ Racial composition of the county

\footnotetext{
${ }^{9}$ High school/some college is not significant for Woodard.

${ }^{10}$ In analyses not shown, separate models were run with each regional classification mediated by smoking and models of sex-specific mortality regressed on smoking behavior alone. Analyses available upon request.
} 
and reaching sufficient levels of physical activity remain strong as well while labor force participation added little to the models.

\section{Comparison of Models for US Census Divisions}

Tables 16 and 17 summarize the findings of Models 1-6 using the census divisions for males and females, respectively. Of the six Models examined, the census divisions' model in Model 5a is the best fit for explaining variation in male mortality as evidenced by its highest adjusted $\mathrm{R}^{2}(0.6434)$ and lowest AIC $(37,129)$ and BIC $(37,334)$ scores; it predicts only about $1.7 \%$ more than the census divisions' model in Model 3a with the sex-specific (except for percent without health insurance) "people" mediators, $4.1 \%$ more than in Model 4a with all the mediators except smoking behavior and labor force participation, and 21.3\% more than in Model 2a with just the "place" mediators. Model 2a is the worst fitting model that included any mediators and even explains 7.9\% less than Model 6a including just the census divisions and smoking behavior. ${ }^{11}$

Declaring a best fitting model for explaining variation in female mortality is slightly more complex. Of the six models examined, the census divisions' model in Model 5b is the best fit for explaining variation in female mortality as evidenced by its highest adjusted $R^{2}(0.6174)$ and lowest AIC (35,177); however, it is Model 3b that has the lowest BIC $(35,358)$ score. The adjusted $\mathrm{R}^{2}$ of Model $2 \mathrm{~b}$ is 0.6063 and its AIC score is 35,249 while the BIC of Model $3 \mathrm{~b}$ is 35,382. BIC scores account for the number of parameters in a model, whereas AIC scores do not; thus, since Model 5b has more mediators, the BIC score will penalize Model 5b more so as such a complex model (Smith 2016). BIC scores tend to advocate for more parsimonious models - that is, they prefer using simpler (i.e., fewer variables) explanations that explain the same amount of information. Since Model $3 \mathrm{~b}$ explained roughly the same amount of variation as Model 5b, but with fewer factors, BIC found Model 3b to be a better fit. According to Raftery (1996), a difference of 10 or more in BIC scores indicates "very strong" evidence for accepting another model with a lower BIC score. Thus, Model $5 \mathrm{~b}$ may be the better fit model according to its adjusted R2 and AIC scores, but the BIC suggests that the simpler Model 3b is a better model that explains roughly the same amount of variation with fewer variables. Of the rest of the

\footnotetext{
${ }^{11}$ Analyses were run examining the census divisions with a smoking interaction term in each of the Models that contained both regional classifications and smoking (i.e., Models 3, 5, and 6); although the interaction was significant, it did not change the fit of the model or direction of relationships substantially. Interaction Models are not included in the Appendix or discussed in the Results, but are available upon request.
} 
Models with mediators, Model $2 \mathrm{~b}$ and its "place" mediators is decidedly the worst fitting model with the lowest adjusted $\mathrm{R}^{2}(0.3996)$ and highest AIC $(36,552)$ and BIC $(36,702)$ scores. Model $6 \mathrm{~b}$, with only census divisions and smoking behavior, explains more variation in female mortality than Model $2 \mathrm{~b}$ by $8.4 \%$.

Maps

Eleven choropleth maps illustrate: (1) the three regional classifications (Figures 1-3) ${ }^{12}$;

(2) female and male mortality rates with an outline of the borders of each regional classification (Figures 4-9) ${ }^{13}$; and (3) female and male mortality rates with overlapping borders of all three regional classifications (Figures 10-11).

Figures 4 and 5 demonstrate the male and female (respectively) age-adjusted, all-cause mortality rates across the US with an outline of the census divisions. For both sexes, East South Central, West South Central, and part of South Atlantic appear to have the most counties with higher rates of mortality while West North Central has some noticeably large counties with higher mortality rates as well. New England, Middle Atlantic, and potentially East North Central appear to be the most homogenous with mainly lower mortality rates. The Mountain and Pacific regions appear to be slightly more heterogeneous, which may explain their typically nonsignificant results.

Figures 6 and 7 demonstrate the male and female (respectively) age-adjusted, all-cause mortality rates across the US with an outline of Woodard's nations. The Deep South, Greater Appalachia, and New France appear to have the most counties with higher rates of mortality while the Far West has some noticeably large counties with higher mortality rates as well. Yankeedom, the Spanish Caribbean, and potentially the Midlands and New Netherlands appear to be the most homogenous with mainly lower mortality rates. Tidewater appears to be homogenous with mainly higher mortality rates, though not as high as in the Deep South and Greater Appalachia. The Left Coast and El Norte appear to be slightly more heterogeneous, which may explain their typically non-significant results.

Figures 8 and 9 demonstrates the male and female (respectively) age-adjusted, all-cause mortality rates across the US with an outline of Garreau's nations. Dixie appears to have the most counties with higher rates of mortality while the Breadbasket and The Empty Quarter have

\footnotetext{
${ }^{12}$ Colored versions of these maps are available upon request. These maps visually demonstrate the nations and divisions discussed in the Literature Review - they will not be discussed again in the Results.

${ }^{13}$ Colored versions of these maps are available upon request.
} 
some noticeably large counties with higher mortality rates as well. New England, The Islands, and potentially The Foundry appear to be the most homogenous with mainly lower mortality rates. Ecotopia and MexAmerica appear to be slightly more heterogeneous, which may explain Ecotopia's typically non-significant results and MexAmerica's non-significant results in Model $1 \mathrm{a}$ and $1 \mathrm{~b}$.

According to Figures 10-11, Woodard's "American Nations" do seem to encapsulate the clusters of unhealthy places in the southwest through three nations (i.e., Greater Appalachia, Deep South, and New France), but include some of the lower mortality rates in mid-Texas and mid-Florida. The census division East South Central, West South Central, and South Atlantic catch higher mortality rates while including many other lower mortality counties-particularly in Texas, southern Florida, Virginia, and North Carolina. Garreau's Dixie covers most of the southwestern high mortality rates, but misses the higher rates in Oklahoma and northern Texas while including lower ones in mid-Florida, North Carolina, and Virginia. Woodard's nations also appear to better encompass the healthy places within Yankeedom, the Spanish Caribbean, New Netherlands, and the Midlands. Of the census divisions, New England, Middle Atlantic, and East North Central appear to encapsulate mainly healthy places, but East North Central has several counties with higher mortality its lower portion. In Garreau's nations, New England and The Foundry appear to capture mainly healthy places, but The Foundry has some counties with higher mortality towards its southern area. Being able to compare the overlapping nation boundaries on top of the sex-specific mortality helps us to visually examine the shortcomings or advantages of each regional classification to help understand the results of the regression analyses (particularly for Models 1a and 1b).

\section{DISCUSSION}

\section{Hypothesis One}

Hypothesis one ${ }^{14}$ posited that Woodard's "American Nations" will continue to explain more variance in the new models (i.e., Models $5 \mathrm{a}$ and $5 \mathrm{~b}$ ) predicting sex-specific mortality rates than the US Census Bureau's or Garreau's classifications; and the US Census Bureau's classifications will explain more variance than Garreau's classification. This hypothesis was supported for both sexes as evidenced by Woodard's “American Nations" showing the highest adjusted $\mathrm{R}^{2}$ values in Models $5 \mathrm{a}$ and $5 \mathrm{~b}$ and the lowest AIC and BIC scores in both Models.

\footnotetext{
${ }^{14}$ See Table 2 for a summary of hypotheses, whether or not they were supported, and which evidence was used.
} 
However, the differences in adjusted $\mathrm{R}^{2}$ values between Woodard and the least fit model in Models 5a and 5b (both, Garreau's "Nine Nations") was $1.4 \%$ for females and $0.8 \%$ for males. Woodard's better fit was only $0.5 \%$ and $0.6 \%$ for males and females compared to the census divisions in both Models, respectively.

Even though Woodard's "American Nations" does a little better in the base models (Models 1a and 1b) than the census divisions and Garreau's "Nine Nations" than it does in the Models 5a and 5b, the differences are still not that large (less than 3.6\%). Woodard's nations may capture more similar cultures within their county-level boundaries that influence some of the "people" mediators used in this study. For example, the Deep South, Greater Appalachia, and New France had some of the highest average percentages of obese residents and those who smoked daily along with the highest average mortality rates for both sexes. While Woodard focuses on the historical settlement of these nations and the shared beliefs and dispositions of the residents, these cultural aspects most likely translate into common actions and behaviors which were deemed mediators in the models. As we see in the models, the inclusion of some of these particular mediators reduces the predictive power of Woodard's nations indicating they were most likely driving Woodard's predictive power in the base models. In other words, the cultural aspects Woodard's nations were based on may have affected these mediators, which in turn affected mortality rates. Models 5a and 5b suggest that Woodard's nations (or any regional classification) do little more to explain differences in mortality than the mediator variables alone. Woodard's nations may capture these common behaviors and factors better than the census divisions do, and through these models, we can tease apart the ones that most contribute to mortality disparities.

Smoking was indeed an important mediator, but labor force participation did little to predict mortality. An increase in the percent of the county population that is white (compared to “other") along with an increase in reaching sufficient physical activity levels were strong predictors of lower mortality rates. As obesity, inequality (evidenced by the Gini index) and the percent of those with no health insurance and a high school degree/some college (compared to less than high school) increased, mortality rates also significantly increased. Farming- and service-dependent counties predicted lower mortality rates while mining-dependent counties predicted higher mortality rates than nonspecialized-dependent counties. These typologies may indicate environmental conditions in these counties as well. Farming-dependent counties most 
likely have more open farmland versus mining-dependent counties that may have more factories that contaminate air or water around them. Previous research found similar results regarding county-level agricultural and mining environments (Hendryx, Fedorko, and Halverson 2010) and poor health conditions among local miners (Antao et al. 2005). RUCC codes were not generally significant predictors in Models 5a or 5b, except for Garreau's models predicting female mortality and partially for male mortality.

Woodard's nations' ability to explain slightly more of the mortality variation than the census divisions' models in the base models, but then reach a much closer explanatory power to the census divisions in Models 5a and 5b may indicate that these mediators were some of the main concepts of culture that Woodard had captured better within his regional groupings that the US Census Bureau has not caught within their divisions.

Hypothesis Two

My second hypothesis was that with the addition of the measures on smoking and labor force participation, the new models (Models 5a, and 5b) would predict female and male mortality with less of a discrepancy than the previous models (Models $4 \mathrm{a}$ and $4 \mathrm{~b}$ ). This hypothesis was supported for the census division models, but not for Woodard's or Garreau's nations. In Models 4a and 4b: the census divisions and mediator variables explain 3.7\% more of male mortality than female mortality; Woodard's nations and the mediator variables explain $2.6 \%$ more of male mortality than female mortality; Garreau's nations and the mediator variables explain $3.1 \%$ more of male mortality than female mortality. In Models 5a and 5b: the census divisions and mediator variables explain $2.6 \%$ more of male mortality than female mortality; Woodard's nations and the mediator variables explain $2.6 \%$ more of male mortality than female mortality; Garreau's nations and the mediator variables explain 3.2\% more of male mortality than female mortality. The additional factors help lessen the difference in explanatory power for the census divisions, have no effect on the difference for Woodard's models, and negligibly increased the difference for Garreau's models.

In their base models (Models $1 \mathrm{a}$ and $1 \mathrm{~b}$ ) the census divisions explain $0.9 \%$ more of male mortality than female mortality; Woodard's nations explain $0.4 \%$ more of female mortality than male mortality; Garreau's nations explain $2.7 \%$ more of male mortality than female mortality. The census divisions and Woodard's nations roughly explain the same variation in mortality for males and females (as they did for Models $5 \mathrm{a}$ and $5 \mathrm{~b}$ where both had a $2.6 \%$ difference), but 
once mediators are included, differences emerge in predictive quality (i.e., from less than $1.0 \%$ difference between sexes to a $2.6 \%$ difference between sexes). This change in differences in sex-specific explanatory power suggests that the census divisions and Woodard's nations are able to capture aspects of their regions that have similar impacts on male and female mortality; however, the mediators applied to these models do not encompass all of those aspects. That is, in holding these mediating factors constant, the remaining variance to be explained determined by regions explains slightly more of the variation of female mortality.

\section{Hypothesis Three}

My third hypothesis was that the "place" models would explain more variance in mortality than the "people" models. This hypothesis was not supported for either sex; in fact, the "people" models explain approximately $20 \%$ more variation in mortality than the "place" models. Smoking behavior was consistently the strongest predictor in each model it was in except for a couple in Model $6 \mathrm{~b}$ where one of Woodard's nations (i.e., Deep South) and one of Garreau's nations (i.e., Dixie) were stronger predictors of mortality rates for females. This finding suggests that attributes of these regions still strongly affect female mortality even when controlling for the percent of those who smoke daily by county. Additionally, physical activity, obesity, education, and racial composition, were also consistently strong. Most or all RUCCs lost their significance once "people" mediators were included which is consistent with previous research showing RUCCs accounted for only $4.4 \%$ of the explanation of non-sex-specific 20082012 age-adjusted, all-cause mortality (Cossman, Wolf, and Myers 2016a). Typology and medical care mediators were moderately strong predictors; however, Gini remained relatively strong across models.

Research has shown smoking has a strong effect on mortality rates, and this study supports those findings (Rogers et al. 2005). Smoking behavior alone counted for $42.2 \%$ of the variation in male mortality which was nearly $10 \%$ more than any of the regional classifications alone; however, smoking explained roughly the same amount of variation in female mortality as any of the regional classifications (approximately 30\%). For males, smoking explained about the same amount of variation in mortality as the regional classification models in Model 2a; though for females it explained roughly 10\% less than any of the regional classification models in Model 2b. Nevertheless, smoking grouped with sufficient physical activity levels, racial composition, obesity, and education outperformed the selected "place" variables in explaining mortality. 


\section{Exploratory Maps}

The maps were used to explore whether the preliminary findings of Woodard's nations only slightly predicting mortality better than the US Census Bureau's divisions or Garreau's nations may be due to how large the regions are within each classification. Although only examined visually, this was seemingly supported as most regional classifications had a similar number of nations or divisions with homogeneous and heterogeneous mortality rates. For example, the US Census Bureau's West North Central, Mountain, and Pacific divisions, Woodard's Far West, El Norte and Left Coast, Garreau's Empty Quarter, Breadbasket, Ecotopia, and MexAmerica all largely encompass areas with a variety of mortality levels. On the other hand, the other regions within each classification largely encompass either mainly healthy places or unhealthy places.

Garreau is the only one to miss a large chunk of the southern high mortalities in a southern nation; instead, the counties with high mortality in Texas and Oklahoma are encapsulated in the Breadbasket along with plenty of lower mortality counties. This finding may be why Garreau's model fit is typically the worst in each Model. Contrarily, Woodard seems to capture the many high mortality counties within his southern nations and more homogenous nations of Yankeedom and the Midlands. The large, block of the Far West and the other heterogeneous nations most likely contribute to a downfall of Woodard's predictive capability. The three southeastern divisions of the US Census Bureau capture the majority of the high mortality counties as well as relatively homogenous northwestern divisions, but the southwestern divisions also include areas of lower mortality in Florida and southeastern Texas. Again, the three large census divisions in the east with heterogeneous mortality levels may contribute to poor predictive ability.

\section{LIMITATIONS}

A limitation of this study might be that the "place" mediators that were used did not include measures of the built environment (e.g., parks, sidewalks, land use) or the natural environment (e.g., plant life, air quality, and climate) outside of rurality. The typology mediators may have captured some of these aspects, but did not do so explicitly. Montez, Zajacova, and Hayward (2016) found state-level contextual factors to explain more variation in female mortality than personal characteristics; perhaps including more similar county-level factors would help increase the predictive quality of "place" mediators. 
Another limitation of this work was the lack of political or religious potentially mediating factors. Woodard (2011) highlights the typical political and religious ideologies and affiliations found within his nations. For example, he notes the Midlands were settled by Quakers, but were welcoming of others, leading to a pluralistic society with a "moderate, even apathetic" approach to politics, while Yankeedom's religious beginnings have instilled a Puritan-like moral and social code and strong support of their government (6). Religious involvement has been found to be related to mortality risks (Hummer et al. 2004). Political factors ideologies and policies can be complex as policies (e.g., regarding healthcare) can be enacted at the federal or state level while ideologies can cross these lines, or show differences within states, and potentially affect mortality rates (e.g., Hatzenbuehler 2011).

Other limitations include the use of OLS regression rather than spatial regression, that this was a cross-sectional study that did not look at changes in mortality or other variables over time, and that examination of the maps was only visual rather than using more powerful methods such as cluster analysis.

\section{FUTURE RESEARCH}

Future research could include more environmental, economic, political, or religious variables to determine what Woodard's nations account for that the census divisions do not. This thesis also used OLS regression to examine the predictive power of the regional classifications. Future analyses can use more sophisticated techniques such as spatial regression modeling. Additionally, since this was a cross-sectional study and Woodard's thesis was published in 2011 (even though it is about the historical settlement of regions, contemporary influences may have been at play), future work can use longitudinal analyses to examine if Woodard's nations' hold their predictive capability over time.

Future studies could also examine the predictability of sex-specific mortality with smaller, more homogenous regions. For example, in research not shown, the predictability of either male or female mortality by state is about $10 \%$ stronger than any of the three regional classifications. ${ }^{15}$ Individual states may show more potential due to laws or policies within each state or because there are fifty of them rather than less than twelve. Research has found strong associations between state-level factors (e.g., public expenditure on education) and state-level all-cause mortality (Dunn, Burgess, and Ross 2005). As previously stated, a more recent study

\footnotetext{
${ }^{15}$ Analyses available upon request.
} 
found significant disparities between states regarding female mortality levels; though contextual factors, and - to a lesser degree — personal characteristics were found to explain a great deal of the variation in mortality (Montez, Zajacova, and Hayward 2016). While the census divisions are outlined at the state level, perhaps less similar states are grouped together, or more groups could be formed to explain mortality variation.

While the maps provided here allow for a visual examination of the sex-specific mortality rates within or across regions, they do not conclusively say whether or not certain nations or divisions are capturing full or complete clusters. Cluster analyses can be run on the maps used to demonstrate the overlap in regions on whether or not certain areas are indeed capturing clusters of healthy or unhealthy places. These analyses can show where the male and female mortality rates cluster at higher or lower rates, and whether or not they are within certain regional boundaries.

\section{CONCLUSION}

Overall, Woodard's “American Nations” do explain greater variance in 2008-2012 ageadjusted, all-cause, female and male mortality in the United States; however, the difference in explanatory power is quite small compared to the nine census divisions. Thus, it would not be imperative to switch to using his classification in the research field. On the other hand, this is a cross-sectional study; if future research found that Woodard's nations were consistently stronger than the census divisions over time and at a greater difference in all-cause mortality, causespecific mortality, or another health outcome, then perhaps shifts in standard methodology could become advantageous.

These findings suggest that taking into account the historical settlement of areas may help explain some differences in mortality or potentially other health outcomes. Since the census divisions were not developed from any sociological theories, the strength in predicting sexspecific mortality may stem from their use of state borders and the administrative, political, and legal similarities found within states. Further analyses can investigate the affect state laws and policies have on mortality compared to these divisions and cultural/economic nations.

This study also highlights the large effect smoking has on mortality. Congruent with most research on smoking (Rogers et al. 2005), these findings show how harmful smoking is for one's health. Policymakers could benefit from actively pursuing ways to decrease smoking in America with a particular focus on southern and Appalachian areas. 


\section{REFERENCES}

Antao, V. C. dos S., E. L. Petsonk, L. Z. Sokolow, A. L. Wolfe, G. A. Pinheiro, J. M. Hale, and M. D. Attfield. 2005. "Rapidly Progressive Coal Workers' Pneumoconiosis in the United States: Geographic Clustering and Other Factors." Occupational and Environmental Medicine 62 (10): 670-74. doi:10.1136/oem.2004.019679.

Area Health Resource File. 2012. "National County-Level Health Resource Information Database." Health Resources and Services Administration.

Batagelj, Vladimir, Patrick Doreian, Anuska Ferligoj, and Natasa Kejzar. 2014. Understanding Large Temporal Networks and Spatial Networks: Exploration, Pattern Searching, Visualization and Network Evolution. John Wiley \& Sons.

Bower, Kaile. 2010. "Looking Back and Ahead: A History of Cartography at the Cenus Bureau and What the Future Holds." presented at the A special joint symposium of ISPRS Technical Commission IV \& AutoCarto in conjunction with ASPRS/CaGIS 2010 Fall Specialty Conference, Orlando, FL, November 15. https://www.census.gov/history/pdf/cartographyatcensus.pdf.

Caldwell, Steven, and Theodore Diamond. 1979. "Income Differentials in Mortality: Preliminary Results Based on IRS-SSA Linked Data." Statistical Uses of Administrative Records with Emphasis on Mortality and Disability Research. Social Security Administration:

Washington, 51-59.

Case, Anne, and Angus Deaton. 2015. "Rising Morbidity and Mortality in Midlife among White Non-Hispanic Americans in the 21st Century." Proceedings of the National Academy of Sciences 112 (49): 15078-83. doi:10.1073/pnas.1518393112.

Centers for Disease Control and Prevention. 2016. CDC Wonder. http://wonder.cdc.gov/ucdicd10.html.

Cosby, Arthur G., Tonya T. Neaves, Ronald E. Cossman, Jeralynn S. Cossman, Wesley L. James, Neal Feierabend, David M. Mirvis, Carol A. Jones, and Tracey Farrigan. 2008. "Preliminary Evidence for an Emerging Nonmetropolitan Mortality Penalty in the United States." American Journal Of Public Health 98 (8): 1470-72.

Cossman, Jeralynn S., Julia Kay Wolf, and Douglas J. Myers. 2016a. "Defining Regions and Understanding Rurality: Exploring Spatial Variations in American Mortality." presented at the Rural Sociological Society, Toronto, Canada, August. 
_ 2016b. "Understanding Spatial Variation in Mortality: Rural Regions and Cultural Variations." presented at the Southern Demographic Association, Athens, GA, October. Cossman, Jeralynn Sittig, Ronald E. Cossman, Wesley L. James, Carol R. Campbell, Troy C. Blanchard, and Arthur G. Cosby. 2007. "Persistent Clusters of Mortality in the United States." American Journal of Public Health 97 (12): 2148-2150.

Cossman, Ronald E., Jeralynn S. Cossman, Troy C. Blanchard, Wesley L. James, and Arthur Cosby. 2004. "Mortality Rates across Time: Does Persistence Suggest 'Healthy and Unhealthy Places' in the United States?" In WorldMinds: Geographical Perspectives on 100 Problems, edited by DG Janelle, B Warf, and K Hansen, 87-92. Amsterdam: Kluwer Press.

Cutler, David, Angus Deaton, and Adriana Lleras-Muney. 2006. "The Determinants of Mortality." The Journal of Economic Perspectives 20 (3): 97-120. doi:10.1257/089533006780387634.

Dahmann, Donald C. 2015. "Presenting the Nation's Cultural Geography: 1790-1920." National Atlases. Accessed November 7. http://memory.loc.gov/ammem/gmdhtml/census2.html.

Diez-Roux, A V. 1998. "Bringing Context Back into Epidemiology: Variables and Fallacies in Multilevel Analysis." American Journal of Public Health 88 (2): 216-22. doi:10.2105/AJPH.88.2.216.

Dunn, James R., Bill Burgess, and Nancy A. Ross. 2005. "Income Distribution, Public Services Expenditures, and All Cause Mortality in US States." Journal of Epidemiology \& Community Health 59 (9): 768-74. doi:10.1136/jech.2004.030361.

Dwyer-Lindgren, Laura, Greg Freedman, Rebecca E. Engell, Thomas D. Fleming, Stephen S. Lim, Christopher JL Murray, and Ali H. Mokdad. 2013. "Prevalence of Physical Activity and Obesity in US Counties, 2001-2011: A Road Map for Action." Population Health Metrics 11: 7. doi:10.1186/1478-7954-11-7.

Dwyer-Lindgren, Laura, Ali H. Mokdad, Tanja Srebotnjak, Abraham D. Flaxman, Gillian M. Hansen, and Christopher JL Murray. 2014. "Cigarette Smoking Prevalence in US Counties: 1996-2012." Population Health Metrics 12: 5. doi:10.1186/1478-7954-12-5.

Elazar, Daniel J. 1984. American Federalism: A View from the States. 3rded. New York: Harper and Row.

Ezzati, Majid, Ari B. Friedman, Sandeep C. Kulkarni, and Christopher J. L. Murray. 2008. "The 
Reversal of Fortunes: Trends in County Mortality and Cross-County Mortality Disparities in the United States." PLoS Medicine 5 (4): e66. doi:10.1371/journal.pmed.0050066.

Garreau, Joel. 1981. The Nine Nations of North America. Boston: Houghton Mifflin.

Geography, US Census Bureau. 2015a. "2010 Geographic Terms and Concepts - Census

Divisions and Census Regions." Accessed November 7.

https://www.census.gov/geo/reference/gtc/gtc_census_divreg.html.

—. 2015b. "Geographic Areas Reference Manual.” Accessed November 7.

http://www.census.gov/geo/reference/garm.html.

Haines, Michael R. 2001. "The Urban Mortality Transition in the United States, 1800-1940.” In Annales de Démographie Historique, 33-64. Belin. http://www.cairn.info/resume.php?ID_ARTICLE=ADH_101_0033.

Hankey, Steve, Julian D. Marshall, and Michael Brauer. 2015. "Health Impacts of the Built Environment: Within-Urban Variability in Physical Inactivity, Air Pollution, and Ischemic Heart Disease Mortality.” University of British Columbia. https://open.library.ubc.ca/cIRcle/collections/facultyresearchandpublications/52383/items /1.0074708.

Hartzell, David, David Shulman, and Charles Wurtzebach. 1987. "Refining the Analysis of Regional Diversification for Income-Producing Real Estate." Journal of Real Estate Research 2 (2): 85-95. doi:10.5555/rees.2.2.r8916w6t105j718r.

Hatzenbuehler, Mark L. 2011. "The Social Environment and Suicide Attempts in Lesbian, Gay, and Bisexual Youth." Pediatrics 127 (5): 896-903. doi:10.1542/peds.2010-3020.

Hayward, Mark D., Robert A. Hummer, and Isaac Sasson. 2015. "Trends and Group Differences in the Association between Educational Attainment and U.S. Adult Mortality: Implications for Understanding Education's Causal Influence." Social Science \& Medicine, Special Issue: Educational Attainment and Adult Health: Contextualizing Causality, 127 (February): 8-18. doi:10.1016/j.socscimed.2014.11.024.

Hendryx, Michael, Evan Fedorko, and Joel Halverson. 2010. "Pollution Sources and Mortality Rates Across Rural-Urban Areas in the United States.” The Journal of Rural Health 26 (4): 383-91. doi:10.1111/j.1748-0361.2010.00305.x.

Huie, Stephanie A. Bond, Robert A. Hummer, and Richard G. Rogers. 2002. "Individual and Contextual Risks of Death among Race and Ethnic Groups in the United States." Journal 
of Health and Social Behavior 43 (3): 359-81. doi:10.2307/3090209.

Hummer, Robert A., Christopher G. Ellison, Richard G. Rogers, Benjamin E. Moulton, and Ron R. Romero. 2004. "Religious Involvement and Adult Mortality in the United States: Review and Perspective." Southern Medical Journal 97 (12): 1223-31.

Institute for Health Metrics and Evaluation. n.d. "US Data for Download." http://www.healthdata.org/us-health/data-download.

—. 2016. "United States Smoking Prevalence by County 1996-2012 | GHDx." October 21. http://ghdx.healthdata.org/record/united-states-smoking-prevalence-county-1996-2012. James, Wesley L., and Jeralynn S. Cossman. 2016. "Long-Term Trends in Black and White Mortality in the Rural United States: Evidence of a Race-Specific Rural Mortality Penalty." The Journal of Rural Health 0: 1-11. doi:10.1111/jrh.12181.

Kahle, Lynn R. 1986. "The Nine Nations of North America and the Value Basis of Geographic Segmentation." Journal of Marketing 50 (2): 37-47. doi:10.2307/1251598.

Kindig, David A., and Erika R. Cheng. 2013. "Even as Mortality Fell in Most US Counties, Female Mortality Nonetheless Rose in 42.8 Percent of Counties from 1992 to 2006.” Health Affairs 32 (3): 451-58.

Krieger, Nancy, Jarvis T. Chen, Pamela D. Waterman, Mah-Jabeen Soobader, S. V. Subramanian, and Rosa Carson. 2002. "Geocoding and Monitoring of US Socioeconomic Inequalities in Mortality and Cancer Incidence: Does the Choice of Area-Based Measure and Geographic Level Matter? The Public Health Disparities Geocoding Project.” American Journal of Epidemiology 156 (5): 471-82. doi:10.1093/aje/kwf068.

Kunitz, Stephen J. 2014. Regional Cultures and Mortality in America. Cambridge University Press. LeClere, Felicia B., Richard G. Rogers, and Kimberley D. Peters. 1997. "Ethnicity and Mortality in the United States: Individual and Community Correlates." Social Forces 76 (1): 16998. doi:10.1093/sf/76.1.169.

Lieske, Joel. 1993. "Regional Subcultures of the United States." The Journal of Politics 55 (4): 888-913.

Link, Bruce G., and Jo C. Phelan. 2005. "Fundamental Sources of Health Inequalities." In Policy Challenges in Modern Health Care, edited by Lynn B. Rogut, James R. Knickman, David Mechanic, and David Colby, 71-84. Rutgers University Press. https://books.google.com/books?hl=en\&lr=\&id=- 
01NDdoBgBUC\&oi=fnd\&pg=PA71\&dq=0+Link+BG,+Phelan+JC.+Fundamental+sourc es+of+health+inequalities.+Chapter+5+in:+Mechanic+D,+Rogut+LB,+Colby+DC,+Knic kman+JR,+editors.+Policy+challenges+in+modern+health+care.+New+Brunswick+(NJ): +Rutgers+University+Press\%3B+2005.+p.+71\%E2\%80\%9384\&ots=GnCoWhqSQr\&sig =B2UHxbot-hH9WRoagMThfeHEGak.

Lucy, William H. 2003. "Mortality Risk Associated With Leaving Home: Recognizing the Relevance of the Built Environment.” American Journal of Public Health 93 (9): 156469. doi:10.2105/AJPH.93.9.1564.

MacGillis, Alec. 2011. “American Nations' by Colin Woodard, a Study of Our 'rival Regional Cultures." The Washington Post, October 10. https://www.washingtonpost.com/entertainment/books/american-nations-by-colinwoodard-a-study-of-our-rival-regional-cultures/2011/10/10/gIQAvl1IZN_story.html.

Mazanec, Josef A., John C. Crotts, Dogan Gursoy, and Lu Lu. 2015. "Homogeneity versus Heterogeneity of Cultural Values: An Item-Response Theoretical Approach Applying Hofstede's Cultural Dimensions in a Single Nation.” Tourism Management 48 (June): 299-304. doi:10.1016/j.tourman.2014.11.011.

Meara, Ellen R., Seth Richards, and David M. Cutler. 2008. “The Gap Gets Bigger: Changes In Mortality And Life Expectancy, By Education, 1981-2000.” Health Affairs 27 (2): 35060. doi:10.1377/hlthaff.27.2.350.

Miech, Richard A., Jinyoung Kim, Carrie McConnell, and Richard F. Hamman. 2009. “A Growing Disparity in Diabetes-Related Mortality: U.S. Trends, 1989-2005.” American Journal of Preventive Medicine 36 (2): 126-32. doi:10.1016/j.amepre.2008.09.041.

Montez, Jennifer Karas, and Kaitlyn Barnes. 2015. “The Benefits of Educational Attainment for U.S. Adult Mortality: Are They Contingent on the Broader Environment?" Population Research and Policy Review 35 (1): 73-100. doi:10.1007/s11113-015-9377-6.

Montez, Jennifer Karas, and Lisa F. Berkman. 2014. "Trends in the Educational Gradient of Mortality Among US Adults Aged 45 to 84 Years: Bringing Regional Context Into the Explanation." American Journal of Public Health 104 (1): e82-90.

Montez, Jennifer Karas, Robert A. Hummer, Mark D. Hayward, Hyeyoung Woo, and Richard G. Rogers. 2011. "Trends in the Educational Gradient of US Adult Mortality from 1986 through 2006 by Race, Gender, and Age Group.” Research on Aging 33 (2): 145-171. 
Montez, Jennifer Karas, and Anna Zajacova. 2013. "Policy Brief: Why Have Educational Disparities in Mortality Increased among White Women in the United States?" Journal of Health and Social Behavior, May, 22146513491066. doi:10.1177/0022146513491066.

Montez, Jennifer Karas, Anna Zajacova, and Mark D. Hayward. 2016. "Explaining Inequalities in Women's Mortality between U.S. States.” SSM - Population Health 2 (December): 561-71. doi:10.1016/j.ssmph.2016.07.004.

Murray, Christopher J. L., Sandeep C. Kulkarni, Catherine Michaud, Niels Tomijima, Maria T. Bulzacchelli, Terrell J. Iandiorio, and Majid Ezzati. 2006. "Eight Americas: Investigating Mortality Disparities across Races, Counties, and Race-Counties in the United States." PLoS Med 3 (9): e260. doi:10.1371/journal.pmed.0030260.

Myers, Douglas J. 2008. "Epidemiologists, Our Patient Is Society.” New Solutions 18 (2): 107-9. doi:10.2190/NS.18.2.a.

—. 2010. "Education and Health Disparities: A Macro, Not Micro, Phenomenon." New Solutions 20 (2): 175-77. doi:10.2190/NS.20.2.a.

Myers, Douglas J., Courtney Pilkerton, Jeralynn S. Cossman, and Julia Kay Wolf. 2015. “An Exploration of Woodard's 'Cultural Nations' for Predicting Regional Mortality in the US." presented at the Southern Demographic Association Annual Meeting, San Antonio, TX.

Nandi, Arijit, M. Maria Glymour, and S. V. Subramanian. 2014. "Association Among Socioeconomic Status, Health Behaviors, and All-Cause Mortality in the United States:" Epidemiology 25 (2): 170-77. doi:10.1097/EDE.0000000000000038.

Papas, Mia A., Anthony J. Alberg, Reid Ewing, Kathy J. Helzlsouer, Tiffany L. Gary, and Ann C. Klassen. 2007. "The Built Environment and Obesity.” Epidemiologic Reviews 29 (1): 129-43. doi:10.1093/epirev/mxm009.

Raftery, Adrian E. 1996. "Approximate Bayes Factors and Accounting for Model Uncertainty in Generalized Linear Models.” Biometrika 83 (2): 251-66.

Roberts, Megan E., Nathan J. Doogan, Allison N. Kurti, Ryan Redner, Diann E. Gaalema, Cassandra A. Stanton, Thomas J. White, and Stephen T. Higgins. 2016. "Rural Tobacco Use across the United States: How Rural and Urban Areas Differ, Broken down by Census Regions and Divisions." Health \& Place 39 (May): 153-59. doi:10.1016/j.healthplace.2016.04.001. 
Rogers, Richard G., Robert A. Hummer, Patrick M. Krueger, and Fred C. Pampel. 2005. "Mortality Attributable to Cigarette Smoking in the United States." Population and Development Review 31 (2): 259-92. doi:10.1111/j.1728-4457.2005.00065.x.

Satcher, David, George E. Fryer, Jessica McCann, Adewale Troutman, Steven H. Woolf, and George Rust. 2005. "What If We Were Equal? A Comparison Of The Black-White Mortality Gap In 1960 And 2000.” Health Affairs 24 (2): 459-64. doi:10.1377/hlthaff.24.2.459.

Singh, Gopal K. 2003. “Area Deprivation and Widening Inequalities in US Mortality, 19691998.” American Journal of Public Health 93 (7): 1137-43. doi:10.2105/AJPH.93.7.1137.

Singh, Gopal K., Romuladus E. Azuine, Mohammad Siahpush, and Michael D. Kogan. 2012. “All-Cause and Cause-Specific Mortality among US Youth: Socioeconomic and RuralUrban Disparities and International Patterns.” Journal of Urban Health 90 (3): 388-405. doi:10.1007/s11524-012-9744-0.

Singh, Gopal K., and Mohammad Siahpush. 2013. "Widening Rural-Urban Disparities in AllCause Mortality and Mortality from Major Causes of Death in the USA, 1969-2009.” Journal of Urban Health 91 (2): 272-92. doi:10.1007/s11524-013-9847-2.

Smith, Shawna. 2016. "Testing and Fit.” presented at the ICPSR Summer Program, University of Michigan, July 28.

Snyder, Stephen Edward. 2016. "Urban and Rural Divergence in Mortality Trends: A Comment on Case and Deaton." Proceedings of the National Academy of Sciences 113 (7): E815E815.

US Census Bureau. 2016a. “Census 2000 Summary File 3 (SF 3) - Sample Data: Sex by Educational Attainment for the Population 25 Years and Over.” http://factfinder.census.gov/faces/tableservices/jsf/pages/productview.xhtml?pid=DEC_0 0_SF3_P037\&prodType=table.

_. 2016b. "Census 2000 Summary File 3 (SF 3) - Sample Data: Sex by Employment Status for the Population 16 Years and Over." http://factfinder.census.gov/faces/tableservices/jsf/pages/productview.xhtml?pid=DEC_0 0_SF3_P043\&prodType=table.

_. 2016a. “Table C5. Income Inequality Measures by County: 1990, 2000.” Historical 
Income Tables: Counties. Accessed June 16. https://www.census.gov/data/tables/timeseries/dec/historical-income-counties.html.

US Census Bureau, Census History Staff. 2015b. "Directors 1840 - 1865 - History - U.S. Census Bureau." Accessed November 6.

https://www.census.gov/history/www/census_then_now/director_biographies/directors_1 840_-_1865.html\#debow.

- 2015c. "Regions and Divisions - History - U.S. Census Bureau." Accessed November 6. https://www.census.gov/history/www/programs/geography/regions_and_divisions.html.

U.S. Department of Health and Human Services. 2014. "The Health Consequences of Smoking-50 Years of Progress." A Report of the Surgeon General. Rockville (MD): U.S.

Department of Health and Human Services, Centers for Disease Control and Prevention, National Center for Chronic Disease Prevention and Health Promotion, Office on Smoking and Health. http://www.surgeongeneral.gov/library/reports/50-years-ofprogress/exec-summary.pdf.

“USDA ERS - County Typology Codes.” 2017. Accessed February 26. https://www.ers.usda.gov/data-products/county-typology-codes.aspx.

“USDA ERS - Rural-Urban Continuum Codes.” 2016. Accessed October 23. http://www.ers.usda.gov/data-products/rural-urban-continuum-codes.aspx.

Wang, Haidong, Austin E. Schumacher, Carly E. Levitz, Ali H. Mokdad, and Christopher J.L. Murray. 2013. "Left Behind: Widening Disparities for Males and Females in US County Life Expectancy, 1985-2010.” Population Health Metrics 11 (8). doi:10.1186/1478-7954$11-8$.

Wolf, Julia Kay, Jeralynn S. Cossman, and Douglas J. Myers. 2016. “Exploring Woodard's 'American Nations' for Predicting Life Expectancy and Mortality by Sex across the Regions of the United States." presented at the North Central Sociological Association / Midwest Sociological Society, Chicago, IL, April.

Woodard, Colin. 2011. American Nations: A History of the Eleven Rival Regional Cultures of North America. New York: Viking.

Xu, Jiaquan, Sherry L. Murphy, Kenneth D. Kochanek, and Elizabeth Arias. 2016. "Mortality in the United States, 2015." 267. National Center for Health Statistics. https://www.cdc.gov/nchs/data/databriefs/db267.pdf. 


\section{Appendix}

Table 1. Comparison of Model Fit from Preliminary Analyses

\begin{tabular}{|c|c|c|c|c|c|c|c|}
\hline Study & Description & \multicolumn{2}{|c|}{ Census Adj. R2 } & Woodard Adj. R2 & Garreau Adj. R2 \\
\hline Myers et al. 2015 & Mortality 2007 & \multicolumn{2}{|c|}{0.21} & \multicolumn{2}{|c|}{0.25} & \multicolumn{2}{|c|}{0.21} \\
\hline Cossman et al. 2016a & Mortality 2010 & \multicolumn{2}{|c|}{0.32} & \multicolumn{2}{|c|}{0.35} & \multicolumn{2}{|c|}{0.30} \\
\hline & & Female & Male & Female & Male & Female & Male \\
\hline $\begin{array}{c}\text { Cossman et al. 2016b } \\
\text { Wolf et al. 2016 }\end{array}$ & Sex-specific mortality 2010 & 0.29 & 0.30 & 0.33 & 0.32 & 0.27 & 0.29 \\
\hline
\end{tabular}

Note. Base models without controls. 
Table 2. Hypotheses and Results

\begin{tabular}{|c|c|c|}
\hline Hypothesis & Support/Rejected & Evidence \\
\hline $\begin{array}{l}\text { 1: Woodard's “American Nations" } \\
\text { will continue to explain more } \\
\text { variance in the new models (i.e., } \\
\text { including smoking and labor force } \\
\text { participation) predicting sex-specific } \\
\text { mortality rates that the US Census } \\
\text { Bureau's or Garreau's } \\
\text { classifications; and the US Census } \\
\text { Bureau's classifications will explain } \\
\text { more variance than Garreau's } \\
\text { classification. }\end{array}$ & Supported, albeit slightly & $\begin{array}{l}\text { Model 5a (Table \#) } \\
\text { Model 5b (Table \#) }\end{array}$ \\
\hline $\begin{array}{l}\text { 2: The addition of the measures on } \\
\text { smoking and labor force } \\
\text { participation, the new models } \\
\text { (Models } 5 \mathrm{a} \text {, and } 5 \mathrm{~b} \text { ) will predict } \\
\text { female and male mortality more } \\
\text { equally than the previous models } \\
\text { (Models } 4 \mathrm{a} \text { and } 4 \mathrm{~b} \text { ) }\end{array}$ & $\begin{array}{l}\text { Supported for census divisions, not } \\
\text { Woodard's or Garreau's nations }\end{array}$ & $\begin{array}{l}\text { Model 4a (Table \#) } \\
\text { Model 4b (Table \#) } \\
\text { Model 5a (Table \#) } \\
\text { Model 5b (Table \#) }\end{array}$ \\
\hline $\begin{array}{l}\text { 3: The "place" models would explain } \\
\text { more variance in mortality than the } \\
\text { "people" models. }\end{array}$ & Not supported & $\begin{array}{l}\text { Model 2a (Table \#) } \\
\text { Model 3b (Table \#) } \\
\text { Model 3a (Table \#) } \\
\text { Model 3b (Table \#) }\end{array}$ \\
\hline $\begin{array}{l}\text { 4: Preliminary findings that } \\
\text { Woodard's nations only slightly } \\
\text { predict mortality better than the US } \\
\text { Census Bureau's divisions or } \\
\text { Garreau's nations may be due to how } \\
\text { large the regions are within each } \\
\text { classification }\end{array}$ & Supported, cautiously & Maps 4-11 \\
\hline
\end{tabular}


Table 3a. Descriptives of US Census Bureau Divisions

\begin{tabular}{|c|c|c|c|c|c|c|c|c|c|c|}
\hline Variable & USA & $\begin{array}{c}\text { New } \\
\text { England }\end{array}$ & $\begin{array}{c}\text { Mid } \\
\text { Atlantic }\end{array}$ & ENC & WNC & \begin{tabular}{|c|} 
South \\
Atlantic
\end{tabular} & ESC & WSC & Mountain & Pacific \\
\hline \# of counties & 3,109 & 67 & 150 & 437 & 618 & 589 & 364 & 470 & 281 & 133 \\
\hline $\begin{array}{l}\text { \# of counties } \\
\text { included in OLS } \\
\text { Regressions }^{\mathrm{a}}\end{array}$ & 3,070 & 67 & 150 & 437 & 602 & 584 & 364 & 463 & 271 & 132 \\
\hline \multicolumn{11}{|l|}{ \# of RUCCS (\%) } \\
\hline ( & $\begin{array}{c}411 \\
(13.39) \\
\end{array}$ & $\begin{array}{c}16 \\
(23.88) \\
\end{array}$ & $\begin{array}{c}46 \\
(30.67) \\
\end{array}$ & $\begin{array}{c}69 \\
(15.79) \\
\end{array}$ & $\begin{array}{c}34 \\
(5.65) \\
\end{array}$ & $\begin{array}{c}115 \\
(19.69) \\
\end{array}$ & $\begin{array}{c}43 \\
(11.81) \\
\end{array}$ & $\begin{array}{c}50 \\
(10.80) \\
\end{array}$ & $\begin{array}{c}12 \\
(4.43) \\
\end{array}$ & $\begin{array}{c}26 \\
(19.70) \\
\end{array}$ \\
\hline 2 & $\begin{array}{c}322 \\
(10.49) \\
\end{array}$ & $\begin{array}{c}11 \\
(16.42) \\
\end{array}$ & $\begin{array}{c}31 \\
(20.67) \\
\end{array}$ & $\begin{array}{c}52 \\
(11.90) \\
\end{array}$ & $\begin{array}{c}28 \\
(4.65) \\
\end{array}$ & $\begin{array}{c}85 \\
(14.55)\end{array}$ & $\begin{array}{c}31 \\
(8.52)\end{array}$ & $\begin{array}{c}45 \\
(9.72)\end{array}$ & $\begin{array}{c}24 \\
(8.86) \\
\end{array}$ & $\begin{array}{c}15 \\
(11.36) \\
\end{array}$ \\
\hline 3 & $\begin{array}{c}349 \\
(11.37) \\
\end{array}$ & $\begin{array}{c}7 \\
(10.45) \\
\end{array}$ & $\begin{array}{c}12 \\
(8.00) \\
\end{array}$ & $\begin{array}{c}52 \\
(11.90) \\
\end{array}$ & $\begin{array}{c}50 \\
(8.31) \\
\end{array}$ & $\begin{array}{c}87 \\
(14.90) \\
\end{array}$ & $\begin{array}{c}44 \\
(12.09) \\
\end{array}$ & $\begin{array}{c}48 \\
(10.37) \\
\end{array}$ & $\begin{array}{c}25 \\
(9.23) \\
\end{array}$ & $\begin{array}{c}24 \\
(18.18) \\
\end{array}$ \\
\hline 4 & $\begin{array}{c}217 \\
(7.07) \\
\end{array}$ & $\begin{array}{c}7 \\
(10.45) \\
\end{array}$ & $\begin{array}{c}24 \\
(16.00) \\
\end{array}$ & $\begin{array}{c}49 \\
(11.21) \\
\end{array}$ & $\begin{array}{c}15 \\
(2.49) \\
\end{array}$ & $\begin{array}{c}46 \\
(7.88) \\
\end{array}$ & $\begin{array}{c}17 \\
(4.67) \\
\end{array}$ & $\begin{array}{c}29 \\
(6.26) \\
\end{array}$ & $\begin{array}{c}14 \\
(5.17) \\
\end{array}$ & $\begin{array}{c}16 \\
(12.12) \\
\end{array}$ \\
\hline 5 & $\begin{array}{c}101 \\
(3.29) \\
\end{array}$ & $\begin{array}{c}2 \\
(2.99) \\
\end{array}$ & $\begin{array}{c}3 \\
(2.00) \\
\end{array}$ & $\begin{array}{c}14 \\
(3.20) \\
\end{array}$ & $\begin{array}{c}31 \\
(5.15) \\
\end{array}$ & $\begin{array}{c}5 \\
(0.86) \\
\end{array}$ & $\begin{array}{c}13 \\
(3.57) \\
\end{array}$ & $\begin{array}{c}14 \\
(3.02) \\
\end{array}$ & $\begin{array}{c}14 \\
(5.17)\end{array}$ & $\begin{array}{c}5 \\
(3.79)\end{array}$ \\
\hline 6 & $\begin{array}{c}607 \\
(19.77) \\
\end{array}$ & $\begin{array}{c}8 \\
(11.94) \\
\end{array}$ & $\begin{array}{c}23 \\
(15.33) \\
\end{array}$ & $\begin{array}{c}96 \\
(21.97) \\
\end{array}$ & $\begin{array}{c}88 \\
(14.62) \\
\end{array}$ & $\begin{array}{c}128 \\
(21.92) \\
\end{array}$ & $\begin{array}{c}76 \\
(20.88) \\
\end{array}$ & $\begin{array}{c}129 \\
(27.86) \\
\end{array}$ & $\begin{array}{c}38 \\
(14.02) \\
\end{array}$ & $\begin{array}{c}21 \\
(15.91) \\
\end{array}$ \\
\hline 7 & $\begin{array}{c}440 \\
(14.33)\end{array}$ & $\begin{array}{c}10 \\
(14.93)\end{array}$ & $\begin{array}{c}6 \\
(4.00) \\
\end{array}$ & $\begin{array}{c}57 \\
(13.04)\end{array}$ & $\begin{array}{c}121 \\
(20.10)\end{array}$ & $\begin{array}{c}35 \\
(5.99) \\
\end{array}$ & $\begin{array}{c}57 \\
(15.66)\end{array}$ & $\begin{array}{c}71 \\
(15.33) \\
\end{array}$ & $\begin{array}{c}72 \\
(26.57) \\
\end{array}$ & $\begin{array}{c}11 \\
(8.33)\end{array}$ \\
\hline 8 & $\begin{array}{c}226 \\
(7.36) \\
\end{array}$ & $\begin{array}{c}4 \\
(5.97) \\
\end{array}$ & $\begin{array}{c}3 \\
(2.00) \\
\end{array}$ & $\begin{array}{c}22 \\
(5.03) \\
\end{array}$ & $\begin{array}{c}53 \\
(8.80) \\
\end{array}$ & $\begin{array}{c}45 \\
(7.71) \\
\end{array}$ & $\begin{array}{c}42 \\
(11.54) \\
\end{array}$ & $\begin{array}{c}28 \\
(6.05) \\
\end{array}$ & $\begin{array}{c}22 \\
(8.12) \\
\end{array}$ & $\begin{array}{c}7 \\
(5.30) \\
\end{array}$ \\
\hline 9 & $\begin{array}{c}397 \\
(12.93)\end{array}$ & $\begin{array}{c}2 \\
(2.99)\end{array}$ & $\begin{array}{c}2 \\
(1.33)\end{array}$ & $\begin{array}{c}26 \\
(5.95)\end{array}$ & $\begin{array}{c}182 \\
(30.23)\end{array}$ & $\begin{array}{c}38 \\
(6.51)\end{array}$ & $\begin{array}{c}41 \\
(11.26)\end{array}$ & $\begin{array}{c}49 \\
(10.58)\end{array}$ & $\begin{array}{c}50 \\
(18.45)\end{array}$ & $\begin{array}{c}7 \\
(5.30)\end{array}$ \\
\hline \multicolumn{11}{|l|}{ \# Typology (\%) } \\
\hline $\begin{array}{l}\text { Nonspecialized- } \\
\text { dependent }\end{array}$ & $\begin{array}{c}936 \\
(30.49) \\
\end{array}$ & $\begin{array}{c}17 \\
(25.37) \\
\end{array}$ & $\begin{array}{c}37 \\
(24.67) \\
\end{array}$ & $\begin{array}{c}118 \\
(27.00) \\
\end{array}$ & $\begin{array}{c}229 \\
(38.04) \\
\end{array}$ & $\begin{array}{c}145 \\
(24.83) \\
\end{array}$ & $\begin{array}{c}100 \\
(27.47)\end{array}$ & $\begin{array}{c}163 \\
(35.21) \\
\end{array}$ & $\begin{array}{c}67 \\
(24.72) \\
\end{array}$ & $\begin{array}{c}60 \\
(45.45) \\
\end{array}$ \\
\hline Farming & $\begin{array}{c}413 \\
(13.45)\end{array}$ & 0 & 0 & $\begin{array}{c}5 \\
(1.14)\end{array}$ & $\begin{array}{c}192 \\
(31.89)\end{array}$ & $\begin{array}{c}36 \\
(6.16)\end{array}$ & $\begin{array}{c}20 \\
(5.49)\end{array}$ & $\begin{array}{c}86 \\
(18.57)\end{array}$ & $\begin{array}{c}61 \\
(22.51)\end{array}$ & $\begin{array}{c}13 \\
(9.85)\end{array}$ \\
\hline Mining & $\begin{array}{c}125 \\
(4.07)\end{array}$ & 0 & $\begin{array}{c}2 \\
(1.33)\end{array}$ & $\begin{array}{c}12 \\
(2.75)\end{array}$ & $\begin{array}{c}5 \\
(0.83)\end{array}$ & $\begin{array}{c}20 \\
(3.42)\end{array}$ & $\begin{array}{c}11 \\
(3.02)\end{array}$ & $\begin{array}{c}42 \\
(9.07)\end{array}$ & $\begin{array}{c}32 \\
(11.81)\end{array}$ & $\begin{array}{c}1 \\
(0.76)\end{array}$ \\
\hline Manufacturing & $\begin{array}{c}898 \\
(29.25) \\
\end{array}$ & $\begin{array}{c}16 \\
(23.88) \\
\end{array}$ & $\begin{array}{c}49 \\
(32.67) \\
\end{array}$ & $\begin{array}{c}241 \\
(55.15) \\
\end{array}$ & $\begin{array}{c}109 \\
(18.11) \\
\end{array}$ & $\begin{array}{c}199 \\
(34.08) \\
\end{array}$ & $\begin{array}{c}176 \\
(48.35) \\
\end{array}$ & $\begin{array}{c}86 \\
(18.57) \\
\end{array}$ & $\begin{array}{c}7 \\
(2.58) \\
\end{array}$ & $\begin{array}{c}15 \\
(11.36) \\
\end{array}$ \\
\hline Government & $\begin{array}{c}367 \\
(11.95) \\
\end{array}$ & $\begin{array}{c}5 \\
(7.46) \\
\end{array}$ & $\begin{array}{c}17 \\
(11.33) \\
\end{array}$ & $\begin{array}{c}31 \\
(7.09) \\
\end{array}$ & $\begin{array}{c}37 \\
(6.15) \\
\end{array}$ & $\begin{array}{c}103 \\
(17.64) \\
\end{array}$ & $\begin{array}{c}34 \\
(9.34) \\
\end{array}$ & $\begin{array}{c}63 \\
(13.61) \\
\end{array}$ & $\begin{array}{c}58 \\
(21.40) \\
\end{array}$ & $\begin{array}{c}19 \\
(14.39) \\
\end{array}$ \\
\hline Service & $\begin{array}{c}331 \\
(10.78) \\
\end{array}$ & $\begin{array}{c}29 \\
(43.28) \\
\end{array}$ & $\begin{array}{c}45 \\
(30.00) \\
\end{array}$ & $\begin{array}{c}30 \\
(6.86) \\
\end{array}$ & $\begin{array}{c}30 \\
(4.98) \\
\end{array}$ & $\begin{array}{c}81 \\
(13.87) \\
\end{array}$ & $\begin{array}{c}23 \\
(6.32) \\
\end{array}$ & $\begin{array}{c}23 \\
(4.97) \\
\end{array}$ & $\begin{array}{c}46 \\
(16.97) \\
\end{array}$ & $\begin{array}{c}24 \\
(18.18) \\
\end{array}$ \\
\hline \multicolumn{11}{|l|}{ Medical Care } \\
\hline $\begin{array}{l}\text { Active MD rate } \\
\text { (SD) }\end{array}$ & $\begin{array}{c}1.20 \\
(1.34)\end{array}$ & $\begin{array}{c}2.58 \\
(1.75) \\
\end{array}$ & $\begin{array}{c}2.08 \\
(2.07) \\
\end{array}$ & $\begin{array}{c}1.17 \\
(1.01)\end{array}$ & $\begin{array}{c}0.94 \\
(1.33) \\
\end{array}$ & $\begin{array}{c}1.45 \\
(1.74) \\
\end{array}$ & $\begin{array}{c}0.98 \\
(0.96) \\
\end{array}$ & $\begin{array}{c}0.86 \\
(0.82) \\
\end{array}$ & $\begin{array}{c}1.12 \\
(0.87) \\
\end{array}$ & $\begin{array}{c}1.61 \\
(0.99) \\
\end{array}$ \\
\hline $\begin{array}{l}\text { Hospital Bed rate } \\
\text { (SD) }\end{array}$ & $\begin{array}{c}3.89 \\
(5.15) \\
\end{array}$ & $\begin{array}{c}2.78 \\
(1.65) \\
\end{array}$ & $\begin{array}{c}3.79 \\
(3.24) \\
\end{array}$ & $\begin{array}{c}2.89 \\
(2.57) \\
\end{array}$ & $\begin{array}{c}5.81 \\
(7.06) \\
\end{array}$ & $\begin{array}{c}3.69 \\
(6.31) \\
\end{array}$ & $\begin{array}{c}3.39 \\
(3.21) \\
\end{array}$ & $\begin{array}{c}3.19 \\
(4.06) \\
\end{array}$ & $\begin{array}{c}4.36 \\
(5.41) \\
\end{array}$ & $\begin{array}{c}2.81 \\
(2.86) \\
\end{array}$ \\
\hline $\begin{array}{l}\text { No Health Insurance } \\
\text { (SD) }\end{array}$ & $\begin{array}{l}14.68 \\
(4.93) \\
\end{array}$ & $\begin{array}{c}9.32 \\
(2.06)\end{array}$ & $\begin{array}{l}10.83 \\
(2.60) \\
\end{array}$ & $\begin{array}{l}10.63 \\
(2.35) \\
\end{array}$ & $\begin{array}{l}12.42 \\
(4.30)\end{array}$ & $\begin{array}{l}14.95 \\
(3.74) \\
\end{array}$ & $\begin{array}{l}15.73 \\
(3.80) \\
\end{array}$ & $\begin{array}{l}19.22 \\
(4.31) \\
\end{array}$ & $\begin{array}{l}18.89 \\
(4.67) \\
\end{array}$ & $\begin{array}{l}16.80 \\
(4.13) \\
\end{array}$ \\
\hline \multicolumn{11}{|l|}{ Inequality } \\
\hline $\begin{array}{l}\text { Gini } \\
\text { (SD) }\end{array}$ & $\begin{array}{l}43.45 \\
(3.85) \\
\end{array}$ & $\begin{array}{l}42.78 \\
(2.61) \\
\end{array}$ & $\begin{array}{l}42.58 \\
(3.17) \\
\end{array}$ & $\begin{array}{l}40.69 \\
(2.76) \\
\end{array}$ & $\begin{array}{l}41.56 \\
(3.03) \\
\end{array}$ & $\begin{array}{l}44.52 \\
(3.98) \\
\end{array}$ & $\begin{array}{l}46.27 \\
(3.83) \\
\end{array}$ & $\begin{array}{l}45.83 \\
(3.02) \\
\end{array}$ & $\begin{array}{l}42.59 \\
(3.38) \\
\end{array}$ & $\begin{array}{l}43.49 \\
(2.74) \\
\end{array}$ \\
\hline
\end{tabular}

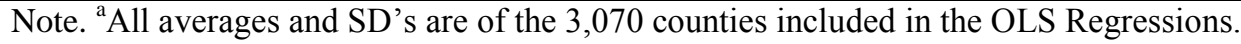

(no Alaska or Hawaii; counties/cities missing mortality data were: Alpine, CA, Arthur, NE, Banner, NE, Billings,

ND, Blaine, NE, Borden, TX, Camas, ID, Clark, ID, Daggett, UT, Glasscock, TX, Grant, NE, Harding, NM, Hayes,

NE, Hinsdale, CO, Jones, SD, Kenedy, TX, Keya Paha, NE, King, TX, Logan, NE, Loupe, NE, Loving, TX,

McMullen, TX, McPherson, NE, Mineral, CO, Petroleum, MT, Roberts, TX, San Juan, CO, Sioux, NE, Slope, ND,

Sully, SD, Thomas, NE, Treasure, MT, Wheeler, NE; counties missing data on mediators: Bedford City, VA,

Broomfield, CO, Clifton Forge City, VA, Fairfax City, VA, Franklin City, VA, Manassas Park City, VA,

Waynesboro City, VA) 
Table 3b. Descriptives of US Census Bureau Divisions - Male

\begin{tabular}{|c|c|c|c|c|c|c|c|c|c|c|}
\hline Variable & USA & $\begin{array}{c}\text { New } \\
\text { England }\end{array}$ & $\begin{array}{c}\text { Mid } \\
\text { Atlantic }\end{array}$ & ENC & WNC & $\begin{array}{c}\text { South } \\
\text { Atlantic }\end{array}$ & ESC & WSC & Mountain & Pacific \\
\hline$\#$ of counties & 3,109 & 67 & 150 & 437 & 618 & 589 & 364 & 470 & 281 & 133 \\
\hline $\begin{array}{l}\text { \# of counties included in OLS } \\
\text { Regressions }^{\mathrm{a}}\end{array}$ & 3,070 & 67 & 150 & 437 & 602 & 584 & 364 & 463 & 271 & 132 \\
\hline $\begin{array}{l}\text { Avg. Male Mortality rate } \\
\text { (SD) }\end{array}$ & $\begin{array}{c}978.60 \\
(170.41) \\
\end{array}$ & $\begin{array}{l}848.79 \\
(75.77) \\
\end{array}$ & $\begin{array}{l}894.39 \\
(96.24) \\
\end{array}$ & $\begin{array}{c}946.71 \\
(109.42) \\
\end{array}$ & $\begin{array}{c}908.62 \\
(148.74) \\
\end{array}$ & $\begin{array}{l}1023.65 \\
(161.48) \\
\end{array}$ & $\begin{array}{l}1166.22 \\
(146.06) \\
\end{array}$ & $\begin{array}{l}1043.59 \\
(152.30) \\
\end{array}$ & $\begin{array}{c}872.16 \\
(156.12) \\
\end{array}$ & $\begin{array}{c}838.67 \\
(103.89) \\
\end{array}$ \\
\hline $\begin{array}{l}\text { Avg. Male Residents } \\
\text { (SD) (in 2000) }\end{array}$ & $\begin{array}{c}44,778.7 \\
(145,289.0) \\
\end{array}$ & $\begin{array}{c}100,791.5 \\
(137,286.8) \\
\end{array}$ & $\begin{array}{c}127,888.2 \\
(189,083.1) \\
\end{array}$ & $\begin{array}{c}50,654.58 \\
(151,167.1) \\
\end{array}$ & $\begin{array}{l}15,728.01 \\
(41,707.7) \\
\end{array}$ & $\begin{array}{c}43,409.19 \\
(89,807.73) \\
\end{array}$ & $\begin{array}{c}22,747.38 \\
(41,149.54) \\
\end{array}$ & $\begin{array}{c}33,634.8 \\
(112,695.8) \\
\end{array}$ & $\begin{array}{l}33,706.63 \\
(116,041.5) \\
\end{array}$ & $\begin{array}{c}163,571.8 \\
(466,286.1) \\
\end{array}$ \\
\hline \multicolumn{11}{|c|}{ MALE } \\
\hline \multicolumn{11}{|l|}{$\%$ Education } \\
\hline $\begin{array}{l}<\mathrm{HS} \\
(\mathrm{SD})\end{array}$ & $\begin{array}{l}23.72 \\
(9.23)\end{array}$ & $\begin{array}{l}16.12 \\
(4.57)\end{array}$ & $\begin{array}{l}19.63 \\
(5.36) \\
\end{array}$ & $\begin{array}{l}18.95 \\
(5.50)\end{array}$ & $\begin{array}{l}19.12 \\
(6.24)\end{array}$ & $\begin{array}{l}27.71 \\
(8.75)\end{array}$ & $\begin{array}{l}32.83 \\
(8.75) \\
\end{array}$ & $\begin{array}{l}28.86 \\
(8.49)\end{array}$ & $\begin{array}{l}18.11 \\
(7.32)\end{array}$ & $\begin{array}{l}19.67 \\
(7.71) \\
\end{array}$ \\
\hline $\begin{array}{l}\text { HS/Some College } \\
(\mathrm{SD})\end{array}$ & $\begin{array}{l}59.31 \\
(7.39) \\
\end{array}$ & $\begin{array}{l}56.54 \\
(5.88) \\
\end{array}$ & $\begin{array}{l}59.06 \\
(7.48) \\
\end{array}$ & $\begin{array}{l}64.67 \\
(5.65) \\
\end{array}$ & $\begin{array}{l}64.40 \\
(5.34) \\
\end{array}$ & $\begin{array}{l}55.44 \\
(6.36) \\
\end{array}$ & $\begin{array}{l}54.57 \\
(5.67) \\
\end{array}$ & $\begin{array}{l}56.18 \\
(6.45) \\
\end{array}$ & $\begin{array}{l}60.86 \\
(6.84) \\
\end{array}$ & $\begin{array}{l}58.30 \\
(7.59) \\
\end{array}$ \\
\hline $\begin{array}{l}\text { 4yr College+ } \\
\text { (SD) }\end{array}$ & $\begin{array}{l}16.97 \\
(8.67) \\
\end{array}$ & $\begin{array}{l}27.33 \\
(8.60) \\
\end{array}$ & $\begin{array}{l}21.31 \\
(9.70) \\
\end{array}$ & $\begin{array}{l}16.38 \\
(7.66) \\
\end{array}$ & $\begin{array}{l}16.49 \\
(6.46) \\
\end{array}$ & $\begin{array}{c}16.84 \\
(10.17) \\
\end{array}$ & $\begin{array}{l}12.70 \\
(6.92) \\
\end{array}$ & $\begin{array}{l}14.96 \\
(6.58) \\
\end{array}$ & $\begin{array}{l}21.03 \\
(9.68) \\
\end{array}$ & $\begin{array}{l}22.03 \\
(9.27) \\
\end{array}$ \\
\hline \multicolumn{11}{|l|}{$\%$ Race } \\
\hline $\begin{array}{l}\text { White } \\
\text { (SD) }\end{array}$ & $\begin{array}{c}87.61 \\
(15.29) \\
\end{array}$ & $\begin{array}{l}94.77 \\
(5.29) \\
\end{array}$ & $\begin{array}{l}90.71 \\
(9.90) \\
\end{array}$ & $\begin{array}{l}94.12 \\
(7.61) \\
\end{array}$ & $\begin{array}{c}94.69 \\
(10.99) \\
\end{array}$ & $\begin{array}{c}76.82 \\
(17.47) \\
\end{array}$ & $\begin{array}{c}81.64 \\
(20.46) \\
\end{array}$ & $\begin{array}{c}84.73 \\
(13.51) \\
\end{array}$ & $\begin{array}{r}92.85 \\
(11.28) \\
\end{array}$ & $\begin{array}{l}90.08 \\
(7.55) \\
\end{array}$ \\
\hline $\begin{array}{l}\text { Black } \\
\text { (SD) }\end{array}$ & $\begin{array}{c}9.10 \\
(14.35) \\
\end{array}$ & $\begin{array}{c}2.51 \\
(4.05)\end{array}$ & $\begin{array}{c}6.39 \\
(7.74) \\
\end{array}$ & $\begin{array}{c}3.59 \\
(5.72) \\
\end{array}$ & $\begin{array}{c}1.42 \\
(3.61) \\
\end{array}$ & $\begin{array}{c}21.11 \\
(17.39) \\
\end{array}$ & $\begin{array}{c}17.08 \\
(20.49) \\
\end{array}$ & $\begin{array}{c}11.36 \\
(13.40) \\
\end{array}$ & $\begin{array}{c}1.03 \\
(1.84) \\
\end{array}$ & $\begin{array}{c}2.31 \\
(3.11)\end{array}$ \\
\hline \multicolumn{11}{|l|}{$\%$ Health Indicator } \\
\hline $\begin{array}{l}\text { Obesity } \\
\text { (SD) }\end{array}$ & $\begin{array}{l}28.77 \\
(3.13) \\
\end{array}$ & $\begin{array}{l}23.75 \\
(2.42) \\
\end{array}$ & $\begin{array}{l}27.37 \\
(2.82) \\
\end{array}$ & $\begin{array}{l}28.36 \\
(1.85) \\
\end{array}$ & $\begin{array}{l}28.85 \\
(2.30) \\
\end{array}$ & $\begin{array}{l}29.62 \\
(3.29) \\
\end{array}$ & $\begin{array}{l}31.11 \\
(2.55) \\
\end{array}$ & $\begin{array}{l}29.90 \\
(2.15) \\
\end{array}$ & $\begin{array}{l}25.53 \\
(3.50) \\
\end{array}$ & $\begin{array}{l}26.48 \\
(2.96) \\
\end{array}$ \\
\hline $\begin{array}{l}\text { Physical Activity } \\
\text { (SD) }\end{array}$ & $\begin{array}{l}52.92 \\
(7.01) \\
\end{array}$ & $\begin{array}{l}62.37 \\
(4.33) \\
\end{array}$ & $\begin{array}{l}56.34 \\
(3.64) \\
\end{array}$ & $\begin{array}{l}55.83 \\
(4.41) \\
\end{array}$ & $\begin{array}{l}53.28 \\
(4.52) \\
\end{array}$ & $\begin{array}{l}51.90 \\
(6.14) \\
\end{array}$ & $\begin{array}{l}44.20 \\
(6.16) \\
\end{array}$ & $\begin{array}{l}49.16 \\
(5.01) \\
\end{array}$ & $\begin{array}{l}59.32 \\
(5.63) \\
\end{array}$ & $\begin{array}{l}61.57 \\
(5.34) \\
\end{array}$ \\
\hline $\begin{array}{l}\text { Smoking } \\
(\mathrm{SD})\end{array}$ & $\begin{array}{l}23.29 \\
(3.87) \\
\end{array}$ & $\begin{array}{l}20.63 \\
(3.12) \\
\end{array}$ & $\begin{array}{l}21.71 \\
(2.92) \\
\end{array}$ & $\begin{array}{l}24.28 \\
(2.99) \\
\end{array}$ & $\begin{array}{l}22.51 \\
(2.96) \\
\end{array}$ & $\begin{array}{l}24.17 \\
(3.07) \\
\end{array}$ & $\begin{array}{l}27.73 \\
(3.80) \\
\end{array}$ & $\begin{array}{l}23.07 \\
(3.29) \\
\end{array}$ & $\begin{array}{l}19.39 \\
(3.22) \\
\end{array}$ & $\begin{array}{l}19.32 \\
(2.53) \\
\end{array}$ \\
\hline \multicolumn{11}{|l|}{ Labor Force } \\
\hline $\begin{array}{l}\text { Unemployment rate } \\
\text { (SD) }\end{array}$ & $\begin{array}{c}57.43 \\
(29.75)\end{array}$ & $\begin{array}{c}50.67 \\
(15.25)\end{array}$ & $\begin{array}{c}63.90 \\
(21.64)\end{array}$ & $\begin{array}{c}58.51 \\
(25.02)\end{array}$ & $\begin{array}{c}46.39 \\
(30.67)\end{array}$ & $\begin{array}{c}53.21 \\
(28.87)\end{array}$ & $\begin{array}{c}62.95 \\
(29.07)\end{array}$ & $\begin{array}{c}59.88 \\
(26.87)\end{array}$ & $\begin{array}{l}62.93 \\
(34.55)\end{array}$ & $\begin{array}{c}83.89 \\
(32.18)\end{array}$ \\
\hline
\end{tabular}

Note. 'All averages and SD's are of the 3,070 counties included in the OLS Regressions.

(no Alaska or Hawaii; counties/cities missing mortality data were: Alpine, CA, Arthur, NE, Banner, NE, Billings, ND, Blaine, NE, Borden, TX, Camas, ID,

Clark, ID, Daggett, UT, Glasscock, TX, Grant, NE, Harding, NM, Hayes, NE, Hinsdale, CO, Jones, SD, Kenedy, TX, Keya Paha, NE, King, TX, Logan, NE,

Loupe, NE, Loving, TX, McMullen, TX, McPherson, NE, Mineral, CO, Petroleum, MT, Roberts, TX, San Juan, CO, Sioux, NE, Slope, ND, Sully, SD, Thomas, NE, Treasure, MT, Wheeler, NE; counties missing data on mediators: Bedford City, VA, Broomfield, CO, Clifton Forge City, VA, Fairfax City, VA, Franklin City, VA, Manassas Park City, VA, Waynesboro City, VA) 
Table 3c. Descriptives of US Census Bureau Divisions - Female

\begin{tabular}{|c|c|c|c|c|c|c|c|c|c|c|}
\hline Variable & USA & $\begin{array}{c}\text { New } \\
\text { England }\end{array}$ & $\begin{array}{c}\text { Mid } \\
\text { Atlantic } \\
\end{array}$ & ENC & WNC & $\begin{array}{c}\text { South } \\
\text { Atlantic }\end{array}$ & ESC & WSC & Mountain & Pacific \\
\hline \# of counties & 3,109 & 67 & 150 & 437 & 618 & 589 & 364 & 470 & 281 & 133 \\
\hline $\begin{array}{l}\text { \# of counties included in } \\
\text { OLS Regressions }^{\mathrm{a}}\end{array}$ & 3,070 & 67 & 150 & 437 & 602 & 584 & 364 & 463 & 271 & 132 \\
\hline $\begin{array}{l}\text { Avg. Female Mortality rate } \\
\text { (SD) }\end{array}$ & $\begin{array}{c}701.45 \\
(119.71) \\
\end{array}$ & $\begin{array}{l}605.80 \\
(50.62) \\
\end{array}$ & $\begin{array}{l}641.20 \\
(62.12) \\
\end{array}$ & $\begin{array}{l}680.99 \\
(79.07) \\
\end{array}$ & $\begin{array}{c}639.84 \\
(118.58) \\
\end{array}$ & $\begin{array}{c}732.74 \\
(106.14) \\
\end{array}$ & $\begin{array}{l}823.96 \\
(96.08) \\
\end{array}$ & $\begin{array}{c}757.34 \\
(107.28) \\
\end{array}$ & $\begin{array}{l}642.85 \\
(104.59) \\
\end{array}$ & $\begin{array}{l}615.13 \\
(80.50) \\
\end{array}$ \\
\hline $\begin{array}{l}\text { Avg. Female Residents } \\
\text { (SD) (in 2000) }\end{array}$ & $\begin{array}{c}46,508.37 \\
(150,864.3)\end{array}$ & $\begin{array}{c}107,448.7 \\
(147,391.8)\end{array}$ & $\begin{array}{l}136,906.1 \\
(208,568.2)\end{array}$ & $\begin{array}{c}52,839.35 \\
(161,285.9)\end{array}$ & $\begin{array}{c}16,260.0 \\
(44,133.07)\end{array}$ & $\begin{array}{c}45,476.9 \\
(95,325.98)\end{array}$ & $\begin{array}{c}24,101.2 \\
(44,745.75)\end{array}$ & $\begin{array}{c}34,515.08 \\
(114,504.2)\end{array}$ & $\begin{array}{c}33,556.97 \\
(115,685.5)\end{array}$ & $\begin{array}{r}164,853.3 \\
(474,867.3)\end{array}$ \\
\hline
\end{tabular}

FEMALE

\begin{tabular}{|c|c|c|c|c|c|c|c|c|c|c|}
\hline \multicolumn{11}{|l|}{$\%$ Education } \\
\hline $\begin{array}{l}<\mathrm{HS} \\
(\mathrm{SD})\end{array}$ & $\begin{array}{l}21.78 \\
(8.41) \\
\end{array}$ & $\begin{array}{l}14.20 \\
(4.43) \\
\end{array}$ & $\begin{array}{l}17.76 \\
(4.45) \\
\end{array}$ & $\begin{array}{l}17.54 \\
(4.53) \\
\end{array}$ & $\begin{array}{l}17.08 \\
(5.99) \\
\end{array}$ & $\begin{array}{l}25.24 \\
(7.42) \\
\end{array}$ & $\begin{array}{l}30.34 \\
(7.27) \\
\end{array}$ & $\begin{array}{l}27.39 \\
(7.74) \\
\end{array}$ & $\begin{array}{l}16.50 \\
(6.71) \\
\end{array}$ & $\begin{array}{l}17.91 \\
(7.00) \\
\end{array}$ \\
\hline $\begin{array}{l}\text { HS/Some College } \\
\text { (SD) }\end{array}$ & $\begin{array}{l}62.20 \\
(6.87) \\
\end{array}$ & $\begin{array}{l}59.68 \\
(5.63) \\
\end{array}$ & $\begin{array}{l}62.63 \\
(6.74) \\
\end{array}$ & $\begin{array}{l}67.44 \\
(4.57) \\
\end{array}$ & $\begin{array}{l}66.60 \\
(5.02) \\
\end{array}$ & $\begin{array}{l}58.80 \\
(5.37) \\
\end{array}$ & $\begin{array}{l}57.29 \\
(5.17) \\
\end{array}$ & $\begin{array}{l}58.43 \\
(6.03) \\
\end{array}$ & $\begin{array}{l}64.46 \\
(7.05) \\
\end{array}$ & $\begin{array}{l}62.76 \\
(7.46) \\
\end{array}$ \\
\hline $\begin{array}{l}\text { 4yr College+ } \\
\text { (SD) }\end{array}$ & $\begin{array}{l}16.02 \\
(7.13) \\
\end{array}$ & $\begin{array}{l}26.12 \\
(7.44) \\
\end{array}$ & $\begin{array}{l}19.61 \\
(7.81) \\
\end{array}$ & $\begin{array}{l}15.02 \\
(6.18) \\
\end{array}$ & $\begin{array}{l}16.33 \\
(5.47) \\
\end{array}$ & $\begin{array}{l}15.95 \\
(7.98) \\
\end{array}$ & $\begin{array}{l}12.37 \\
(5.27) \\
\end{array}$ & $\begin{array}{l}14.18 \\
(5.08) \\
\end{array}$ & $\begin{array}{l}19.04 \\
(8.88) \\
\end{array}$ & $\begin{array}{l}19.33 \\
(8.03) \\
\end{array}$ \\
\hline \multicolumn{11}{|l|}{$\%$ Race } \\
\hline $\begin{array}{l}\text { White } \\
\text { (SD) }\end{array}$ & $\begin{array}{c}87.71 \\
(15.97) \\
\end{array}$ & $\begin{array}{l}94.91 \\
(5.43) \\
\end{array}$ & $\begin{array}{c}91.63 \\
(10.50) \\
\end{array}$ & $\begin{array}{l}94.95 \\
(7.55) \\
\end{array}$ & $\begin{array}{c}94.90 \\
(11.26) \\
\end{array}$ & $\begin{array}{c}76.26 \\
(13.40) \\
\end{array}$ & $\begin{array}{c}81.21 \\
(21.42) \\
\end{array}$ & $\begin{array}{c}85.00 \\
(14.11) \\
\end{array}$ & $\begin{array}{c}93.00 \\
(11.47) \\
\end{array}$ & $\begin{array}{l}90.16 \\
(7.89) \\
\end{array}$ \\
\hline $\begin{array}{l}\text { Black } \\
(\mathrm{SD})\end{array}$ & $\begin{array}{c}8.93 \\
(15.05) \\
\end{array}$ & $\begin{array}{c}2.34 \\
(4.28) \\
\end{array}$ & $\begin{array}{c}5.56 \\
(8.44) \\
\end{array}$ & $\begin{array}{c}2.74 \\
(5.65) \\
\end{array}$ & $\begin{array}{c}1.13 \\
(3.64) \\
\end{array}$ & $\begin{array}{c}21.64 \\
(18.29) \\
\end{array}$ & $\begin{array}{c}17.51 \\
(21.46)\end{array}$ & $\begin{array}{c}11.10 \\
(14.05) \\
\end{array}$ & $\begin{array}{c}0.64 \\
(1.35) \\
\end{array}$ & $\begin{array}{c}1.78 \\
(2.87)\end{array}$ \\
\hline \multicolumn{11}{|c|}{$\%$ Health Indicator } \\
\hline $\begin{array}{l}\text { Obesity } \\
\text { (SD) }\end{array}$ & $\begin{array}{l}31.35 \\
(5.05) \\
\end{array}$ & $\begin{array}{l}25.09 \\
(3.10) \\
\end{array}$ & $\begin{array}{l}28.99 \\
(3.63)\end{array}$ & $\begin{array}{l}29.99 \\
(2.62) \\
\end{array}$ & $\begin{array}{l}29.73 \\
(3.21) \\
\end{array}$ & $\begin{array}{l}33.62 \\
(5.94) \\
\end{array}$ & $\begin{array}{l}35.18 \\
(5.27) \\
\end{array}$ & $\begin{array}{l}33.59 \\
(3.92) \\
\end{array}$ & $\begin{array}{l}27.16 \\
(4.23) \\
\end{array}$ & $\begin{array}{l}29.19 \\
(3.83) \\
\end{array}$ \\
\hline $\begin{array}{l}\text { Physical Activity } \\
\text { (SD) }\end{array}$ & $\begin{array}{l}43.86 \\
(7.98)\end{array}$ & $\begin{array}{l}53.91 \\
(4.97)\end{array}$ & $\begin{array}{l}46.98 \\
(3.88)\end{array}$ & $\begin{array}{l}46.62 \\
(5.23)\end{array}$ & $\begin{array}{l}46.91 \\
(4.34)\end{array}$ & $\begin{array}{l}40.20 \\
(6.44)\end{array}$ & $\begin{array}{l}33.23 \\
(5.14)\end{array}$ & $\begin{array}{l}39.70 \\
(5.17)\end{array}$ & $\begin{array}{l}52.56 \\
(5.68)\end{array}$ & $\begin{array}{l}54.37 \\
(5.62)\end{array}$ \\
\hline $\begin{array}{l}\text { Smoking } \\
\text { (SD) }\end{array}$ & $\begin{array}{l}19.92 \\
(3.78) \\
\end{array}$ & $\begin{array}{l}18.35 \\
(2.68) \\
\end{array}$ & $\begin{array}{l}19.83 \\
(2.99) \\
\end{array}$ & $\begin{array}{l}21.39 \\
(2.83) \\
\end{array}$ & $\begin{array}{l}19.26 \\
(3.11) \\
\end{array}$ & $\begin{array}{l}19.95 \\
(3.30) \\
\end{array}$ & $\begin{array}{l}22.96 \\
(4.30) \\
\end{array}$ & $\begin{array}{l}19.62 \\
(3.70) \\
\end{array}$ & $\begin{array}{l}17.46 \\
(3.80) \\
\end{array}$ & $\begin{array}{l}16.47 \\
(3.38) \\
\end{array}$ \\
\hline \multicolumn{11}{|l|}{ Labor Force } \\
\hline $\begin{array}{l}\text { Unemployment rate } \\
\text { (SD) }\end{array}$ & $\begin{array}{c}57.70 \\
(28.10)\end{array}$ & $\begin{array}{c}44.66 \\
(11.33)\end{array}$ & $\begin{array}{c}56.16 \\
(19.28)\end{array}$ & $\begin{array}{l}49.30 \\
(18.09)\end{array}$ & $\begin{array}{c}40.82 \\
(25.50)\end{array}$ & $\begin{array}{c}62.21 \\
(28.68)\end{array}$ & $\begin{array}{c}74.56 \\
(28.26)\end{array}$ & $\begin{array}{c}65.72 \\
(27.18)\end{array}$ & $\begin{array}{l}57.64 \\
(28.11)\end{array}$ & $\begin{array}{r}76.53 \\
(27.05)\end{array}$ \\
\hline
\end{tabular}

Note. 'All averages and SD's are of the 3,070 counties included in the OLS Regressions.

(no Alaska or Hawaii; counties/cities missing mortality data were: Alpine, CA, Arthur, NE, Banner, NE, Billings, ND, Blaine, NE, Borden, TX, Camas, ID,

Clark, ID, Daggett, UT, Glasscock, TX, Grant, NE, Harding, NM, Hayes, NE, Hinsdale, CO, Jones, SD, Kenedy, TX, Keya Paha, NE, King, TX, Logan, NE,

Loupe, NE, Loving, TX, McMullen, TX, McPherson, NE, Mineral, CO, Petroleum, MT, Roberts, TX, San Juan, CO, Sioux, NE, Slope, ND, Sully, SD, Thomas, NE, Treasure, MT, Wheeler, NE; counties missing data on mediators: Bedford City, VA, Broomfield, CO, Clifton Forge City, VA, Fairfax City, VA, Franklin City, VA, Manassas Park City, VA, Waynesboro City, VA) 
Table 4a. Descriptives of Woodard's American Nations

\begin{tabular}{|c|c|c|c|c|c|c|c|c|c|c|c|c|}
\hline Variable & USA & $\begin{array}{l}\text { Deep } \\
\text { South }\end{array}$ & EI Norte & Far West & $\begin{array}{c}\text { Greater } \\
\text { Appalachia }\end{array}$ & Left Coast & Midlands & New France & \begin{tabular}{c|} 
New \\
Netherlands \\
\end{tabular} & $\begin{array}{c}\text { Spanish } \\
\text { Caribbean }\end{array}$ & Tide-water & Yankeedom \\
\hline \# of counties & 3,109 & 501 & 87 & 429 & 922 & 54 & 465 & 25 & 24 & 12 & 149 & 441 \\
\hline $\begin{array}{l}\# \text { of counties in } \\
\operatorname{OLS}^{\mathrm{a}}\end{array}$ & 3,070 & 501 & 85 & 404 & 917 & 54 & 463 & 25 & 24 & 12 & 144 & 441 \\
\hline \multicolumn{13}{|l|}{ \# RUCCS (\%) } \\
\hline 1 & $\begin{array}{c}411 \\
(13.39) \\
\end{array}$ & $\begin{array}{c}55 \\
(10.98) \\
\end{array}$ & $\begin{array}{c}10 \\
(11.76) \\
\end{array}$ & $\begin{array}{c}14 \\
(3.47) \\
\end{array}$ & $\begin{array}{c}123 \\
(13.41) \\
\end{array}$ & $\begin{array}{c}18 \\
(33.33) \\
\end{array}$ & $\begin{array}{c}47 \\
(10.15) \\
\end{array}$ & $\begin{array}{c}7 \\
(28.00) \\
\end{array}$ & $\begin{array}{c}21 \\
(87.50) \\
\end{array}$ & $\begin{array}{c}4 \\
(33.33) \\
\end{array}$ & $\begin{array}{c}52 \\
(36.11) \\
\end{array}$ & $\begin{array}{c}60 \\
(13.61) \\
\end{array}$ \\
\hline 2 & $\begin{array}{c}322 \\
(10.49) \\
\end{array}$ & $\begin{array}{c}688 \\
(13.57) \\
\end{array}$ & $\begin{array}{c}11 \\
(12.94) \\
\end{array}$ & $\begin{array}{c}27 \\
(6.68) \\
\end{array}$ & $\begin{array}{c}90 \\
(9.81) \\
\end{array}$ & $\begin{array}{c}7 \\
(12.96) \\
\end{array}$ & $\begin{array}{c}48 \\
(10.37) \\
\end{array}$ & $\begin{array}{c}1 \\
(4.00) \\
\end{array}$ & $\begin{array}{c}3 \\
(12.50) \\
\end{array}$ & $\begin{array}{c}3 \\
(25.00) \\
\end{array}$ & $\begin{array}{c}9 \\
(6.25) \\
\end{array}$ & $\begin{array}{c}55 \\
(12.47) \\
\end{array}$ \\
\hline 3 & $\begin{array}{c}349 \\
(11.37)\end{array}$ & $\begin{array}{c}71 \\
(14.17)\end{array}$ & $\begin{array}{c}7 \\
(8.24) \\
\end{array}$ & $\begin{array}{c}40 \\
(9.90) \\
\end{array}$ & $\begin{array}{c}103 \\
(11.23)\end{array}$ & $\begin{array}{c}8 \\
(14.81) \\
\end{array}$ & $\begin{array}{c}48 \\
(10.37) \\
\end{array}$ & $\begin{array}{c}6 \\
(24.00) \\
\end{array}$ & 0 & $\begin{array}{c}1 \\
(8.33) \\
\end{array}$ & $\begin{array}{c}20 \\
(13.89) \\
\end{array}$ & $\begin{array}{c}45 \\
(10.20) \\
\end{array}$ \\
\hline 4 & $\begin{array}{c}217 \\
(7.07) \\
\end{array}$ & $\begin{array}{c}37 \\
(7.39) \\
\end{array}$ & $\begin{array}{c}7 \\
(8.24) \\
\end{array}$ & $\begin{array}{c}18 \\
(4.46) \\
\end{array}$ & $\begin{array}{c}47 \\
(5.13) \\
\end{array}$ & $\begin{array}{c}9 \\
(16.67) \\
\end{array}$ & $\begin{array}{c}39 \\
(8.42) \\
\end{array}$ & $\begin{array}{c}5 \\
(20.00) \\
\end{array}$ & 0 & $\begin{array}{c}1 \\
(8.33) \\
\end{array}$ & $\begin{array}{c}12 \\
(8.33) \\
\end{array}$ & $\begin{array}{c}42 \\
(9.52) \\
\end{array}$ \\
\hline 5 & $\begin{array}{c}101 \\
(3.29) \\
\end{array}$ & $\begin{array}{c}16 \\
(3.19) \\
\end{array}$ & $\begin{array}{c}4 \\
(4.71) \\
\end{array}$ & $\begin{array}{c}17 \\
(4.21) \\
\end{array}$ & $\begin{array}{c}27 \\
(2.94) \\
\end{array}$ & $\begin{array}{c}3 \\
(5.56) \\
\end{array}$ & $\begin{array}{c}17 \\
(3.67) \\
\end{array}$ & 0 & 0 & 0 & $\begin{array}{c}1 \\
(0.69) \\
\end{array}$ & $\begin{array}{c}16 \\
(3.63) \\
\end{array}$ \\
\hline 6 & $\begin{array}{c}607 \\
(19.77) \\
\end{array}$ & $\begin{array}{c}134 \\
(26.75) \\
\end{array}$ & $\begin{array}{c}18 \\
(21.18)\end{array}$ & $\begin{array}{c}52 \\
(12.87) \\
\end{array}$ & $\begin{array}{c}224 \\
(24.43) \\
\end{array}$ & $\begin{array}{c}4 \\
(7.41)\end{array}$ & $\begin{array}{c}72 \\
(15.55) \\
\end{array}$ & $\begin{array}{c}6 \\
(24.00) \\
\end{array}$ & 0 & $\begin{array}{c}3 \\
(25.00) \\
\end{array}$ & $\begin{array}{c}20 \\
(13.89) \\
\end{array}$ & $\begin{array}{c}74 \\
(16.78) \\
\end{array}$ \\
\hline 7 & $\begin{array}{c}440 \\
(14.33) \\
\end{array}$ & $\begin{array}{c}51 \\
(10.18) \\
\end{array}$ & $\begin{array}{c}16 \\
(18.82) \\
\end{array}$ & $\begin{array}{c}90 \\
(22.28) \\
\end{array}$ & $\begin{array}{c}131 \\
(14.29) \\
\end{array}$ & $\begin{array}{c}3 \\
(5.56) \\
\end{array}$ & $\begin{array}{c}70 \\
(15.12) \\
\end{array}$ & 0 & 0 & 0 & $\begin{array}{c}8 \\
(5.56) \\
\end{array}$ & $\begin{array}{c}71 \\
(16.10) \\
\end{array}$ \\
\hline 8 & $\begin{array}{c}226 \\
(7.36) \\
\end{array}$ & $\begin{array}{c}40 \\
(7.98) \\
\end{array}$ & $\begin{array}{c}2 \\
(2.35) \\
\end{array}$ & $\begin{array}{c}35 \\
(8.66) \\
\end{array}$ & $\begin{array}{c}79 \\
(8.62) \\
\end{array}$ & $\begin{array}{c}1 \\
(1.85) \\
\end{array}$ & $\begin{array}{c}23 \\
(4.97) \\
\end{array}$ & 0 & 0 & 0 & $\begin{array}{c}11 \\
(7.64) \\
\end{array}$ & $\begin{array}{c}35 \\
(7.94) \\
\end{array}$ \\
\hline 9 & $\begin{array}{c}397 \\
(12.93) \\
\end{array}$ & $\begin{array}{c}29 \\
(5.79) \\
\end{array}$ & $\begin{array}{c}10 \\
(11.76) \\
\end{array}$ & $\begin{array}{c}111 \\
(27.48) \\
\end{array}$ & $\begin{array}{c}93 \\
(10.14) \\
\end{array}$ & $\begin{array}{c}1 \\
(1.85) \\
\end{array}$ & $\begin{array}{c}99 \\
(21.38) \\
\end{array}$ & 0 & 0 & 0 & $\begin{array}{c}11 \\
(7.64) \\
\end{array}$ & $\begin{array}{c}43 \\
(9.75) \\
\end{array}$ \\
\hline \multicolumn{13}{|l|}{\begin{tabular}{|l|} 
\# Typology (\%) \\
\end{tabular}} \\
\hline Non-dependent & $\begin{array}{c}936 \\
(30.49) \\
\end{array}$ & $\begin{array}{c}144 \\
(28.74)\end{array}$ & $\begin{array}{c}31 \\
(36.47) \\
\end{array}$ & $\begin{array}{c}102 \\
(25.25) \\
\end{array}$ & $\begin{array}{c}293 \\
(31.95) \\
\end{array}$ & $\begin{array}{c}26 \\
(48.15) \\
\end{array}$ & $\begin{array}{c}147 \\
(31.75) \\
\end{array}$ & $\begin{array}{c}10 \\
(40.00) \\
\end{array}$ & $\begin{array}{c}3 \\
(12.50) \\
\end{array}$ & 0 & $\begin{array}{c}41 \\
(28.47) \\
\end{array}$ & $\begin{array}{c}139 \\
(31.52) \\
\end{array}$ \\
\hline Farming & $\begin{array}{c}413 \\
(13.45) \\
\end{array}$ & $\begin{array}{c}54 \\
(10.78) \\
\end{array}$ & $\begin{array}{c}10 \\
(11.76) \\
\end{array}$ & $\begin{array}{c}131 \\
(32.43) \\
\end{array}$ & $\begin{array}{c}67 \\
(7.31) \\
\end{array}$ & 0 & $\begin{array}{c}114 \\
(24.62) \\
\end{array}$ & 0 & 0 & $\begin{array}{c}1 \\
(8.33) \\
\end{array}$ & $\begin{array}{c}3 \\
(2.08) \\
\end{array}$ & $\begin{array}{c}33 \\
(7.48) \\
\end{array}$ \\
\hline Mining & $\begin{array}{c}125 \\
(4.07) \\
\end{array}$ & $\begin{array}{c}6 \\
(1.20) \\
\end{array}$ & $\begin{array}{c}9 \\
(10.59) \\
\end{array}$ & $\begin{array}{c}31 \\
(7.67) \\
\end{array}$ & $\begin{array}{c}66 \\
(7.20) \\
\end{array}$ & 0 & $\begin{array}{c}3 \\
(0.65) \\
\end{array}$ & $\begin{array}{c}6 \\
(24.00) \\
\end{array}$ & 0 & 0 & $\begin{array}{c}1 \\
(0.69) \\
\end{array}$ & $\begin{array}{c}3 \\
(0.68) \\
\end{array}$ \\
\hline Manufacturing & $\begin{array}{c}898 \\
(29.25) \\
\end{array}$ & $\begin{array}{c}180 \\
(35.93)\end{array}$ & 0 & $\begin{array}{c}16 \\
(3.96) \\
\end{array}$ & $\begin{array}{c}343 \\
(37.40) \\
\end{array}$ & $\begin{array}{c}9 \\
(16.67) \\
\end{array}$ & $\begin{array}{c}135 \\
(29.16) \\
\end{array}$ & $\begin{array}{c}5 \\
(20.00) \\
\end{array}$ & $\begin{array}{c}1 \\
(4.17) \\
\end{array}$ & 0 & $\begin{array}{c}36 \\
(25.00) \\
\end{array}$ & $\begin{array}{c}173 \\
(39.23) \\
\end{array}$ \\
\hline Government & $\begin{array}{c}367 \\
(11.95) \\
\end{array}$ & $\begin{array}{c}73 \\
(14.57) \\
\end{array}$ & $\begin{array}{c}26 \\
(30.59) \\
\end{array}$ & $\begin{array}{c}69 \\
(17.08) \\
\end{array}$ & $\begin{array}{c}80 \\
(8.72) \\
\end{array}$ & $\begin{array}{c}9 \\
(16.67) \\
\end{array}$ & $\begin{array}{c}27 \\
(5.83) \\
\end{array}$ & $\begin{array}{c}2 \\
(8.00) \\
\end{array}$ & $\begin{array}{c}1 \\
(4.17) \\
\end{array}$ & $\begin{array}{c}3 \\
(25.00) \\
\end{array}$ & $\begin{array}{c}46 \\
(31.94) \\
\end{array}$ & $\begin{array}{c}31 \\
(7.03) \\
\end{array}$ \\
\hline Service & $\begin{array}{c}331 \\
(10.78) \\
\end{array}$ & $\begin{array}{c}44 \\
(8.78) \\
\end{array}$ & $\begin{array}{c}9 \\
(10.59) \\
\end{array}$ & $\begin{array}{c}55 \\
(13.61) \\
\end{array}$ & $\begin{array}{c}68 \\
(7.42) \\
\end{array}$ & $\begin{array}{c}10 \\
(18.52) \\
\end{array}$ & $\begin{array}{c}37 \\
(7.9) \\
\end{array}$ & $\begin{array}{c}2 \\
(8.00) \\
\end{array}$ & $\begin{array}{c}19 \\
(79.17) \\
\end{array}$ & $\begin{array}{c}8 \\
(66.67) \\
\end{array}$ & $\begin{array}{c}17 \\
(11.81) \\
\end{array}$ & $\begin{array}{c}62 \\
(14.06) \\
\end{array}$ \\
\hline \multicolumn{13}{|l|}{ Medical Care } \\
\hline \begin{tabular}{|l} 
Active MD rate \\
(SD) \\
\end{tabular} & $\begin{array}{c}1.20 \\
(1.34) \\
\end{array}$ & $\begin{array}{c}1.01 \\
(1.00) \\
\end{array}$ & $\begin{array}{c}0.95 \\
(0.79) \\
\end{array}$ & $\begin{array}{c}1.07 \\
(0.86) \\
\end{array}$ & $\begin{array}{c}0.98 \\
(0.93) \\
\end{array}$ & $\begin{array}{c}2.02 \\
(1.17) \\
\end{array}$ & $\begin{array}{c}1.13 \\
(1.59) \\
\end{array}$ & $\begin{array}{c}1.38 \\
(1.28) \\
\end{array}$ & $\begin{array}{c}3.62 \\
(2.12) \\
\end{array}$ & $\begin{array}{c}1.95 \\
(0.96) \\
\end{array}$ & $\begin{array}{c}2.14 \\
(2.66) \\
\end{array}$ & $\begin{array}{c}1.53 \\
(1.53) \\
\end{array}$ \\
\hline $\begin{array}{l}\text { Hospital Bed } \\
\text { rate (SD) }\end{array}$ & $\begin{array}{c}3.89 \\
(5.15) \\
\end{array}$ & $\begin{array}{c}3.37 \\
(3.67) \\
\end{array}$ & $\begin{array}{c}2.18 \\
(2.47) \\
\end{array}$ & $\begin{array}{c}5.34 \\
(6.52) \\
\end{array}$ & $\begin{array}{c}3.16 \\
(3.71) \\
\end{array}$ & $\begin{array}{c}2.11 \\
(2.11) \\
\end{array}$ & $\begin{array}{c}4.76 \\
(5.79) \\
\end{array}$ & $\begin{array}{c}3.10 \\
(2.56)\end{array}$ & $\begin{array}{c}3.92 \\
(1.80) \\
\end{array}$ & $\begin{array}{c}4.05 \\
(2.90) \\
\end{array}$ & $\begin{array}{c}4.97 \\
(10.71) \\
\end{array}$ & $\begin{array}{c}3.98 \\
(4.68) \\
\end{array}$ \\
\hline
\end{tabular}




\begin{tabular}{|c|c|c|c|c|c|c|c|c|c|c|c|c|}
\hline $\begin{array}{l}\% \text { No Health } \\
\text { Insurance (SD) }\end{array}$ & $\begin{array}{l}14.68 \\
(4.93) \\
\end{array}$ & $\begin{array}{l}17.76 \\
(3.47) \\
\end{array}$ & $\begin{array}{l}25.18 \\
(5.42) \\
\end{array}$ & $\begin{array}{l}17.50 \\
(4.36) \\
\end{array}$ & $\begin{array}{l}14.72 \\
(4.22) \\
\end{array}$ & $\begin{array}{l}14.31 \\
(2.47) \\
\end{array}$ & $\begin{array}{l}11.50 \\
(3.64) \\
\end{array}$ & $\begin{array}{l}16.42 \\
(1.93) \\
\end{array}$ & $\begin{array}{l}12.67 \\
(4.17) \\
\end{array}$ & $\begin{array}{l}15.42 \\
(3.89) \\
\end{array}$ & $\begin{array}{l}13.42 \\
(3.22) \\
\end{array}$ & $\begin{array}{l}10.27 \\
(2.45) \\
\end{array}$ \\
\hline Inequality & & & & & & & & & & & & \\
\hline $\begin{array}{l}\text { Gini } \\
\text { (SD) }\end{array}$ & $\begin{array}{l}43.45 \\
(3.85)\end{array}$ & $\begin{array}{l}46.55 \\
(3.88)\end{array}$ & $\begin{array}{l}46.18 \\
(2.77)\end{array}$ & $\begin{array}{l}42.55 \\
(3.06)\end{array}$ & $\begin{array}{l}44.05 \\
(3.44)\end{array}$ & $\begin{array}{l}13.18 \\
(3.11)\end{array}$ & $\begin{array}{l}41.02 \\
(3.02)\end{array}$ & $\begin{array}{l}46.13 \\
(3.37)\end{array}$ & $\begin{array}{l}46.05 \\
(5.44)\end{array}$ & $\begin{array}{l}46.87 \\
(3.09)\end{array}$ & $\begin{array}{l}43.69 \\
(4.33)\end{array}$ & $\begin{array}{l}41.11 \\
(2.43)\end{array}$ \\
\hline
\end{tabular}

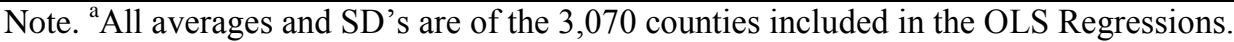

(no Alaska or Hawaii; counties/cities missing mortality data were: Alpine, CA, Arthur, NE, Banner, NE, Billings, ND, Blaine, NE, Borden, TX, Camas, ID, Clark, ID, Daggett, UT, Glasscock, TX, Grant, NE, Harding, NM, Hayes, NE, Hinsdale, CO, Jones, SD, Kenedy, TX, Keya Paha, NE, King, TX, Logan, NE, Loupe, NE, Loving, TX, McMullen, TX, McPherson, NE, Mineral, CO, Petroleum, MT, Roberts, TX, San Juan, CO, Sioux, NE, Slope, ND, Sully, SD, Thomas, NE, Treasure, MT, Wheeler, NE; counties missing data on mediators: Bedford City, VA, Broomfield, CO, Clifton Forge City, VA, Fairfax City, VA, Franklin City, VA, Manassas Park City, VA, Waynesboro City, VA) 
Table 4b. Descriptives of Woodard's American Nations - Male

\begin{tabular}{|c|c|c|c|c|c|c|c|c|c|c|c|c|}
\hline Variable & USA & $\begin{array}{l}\text { Deep } \\
\text { South }\end{array}$ & El Norte & Far West & $\begin{array}{c}\text { Greater } \\
\text { Appalachia }\end{array}$ & Left Coast & Midlands & $\begin{array}{c}\text { New } \\
\text { France }\end{array}$ & $\begin{array}{c}\text { New } \\
\text { Netherlands }\end{array}$ & $\begin{array}{c}\text { Spanish } \\
\text { Caribbean }\end{array}$ & Tidewater & Yankeedom \\
\hline \# of counties & 3,109 & 501 & 87 & 429 & \begin{tabular}{|l|}
922 \\
\end{tabular} & 54 & 465 & 25 & 24 & 12 & 149 & 441 \\
\hline $\begin{array}{l}\text { \# of counties } \\
\text { included in OLS } \\
\text { Regressions }^{\mathrm{a}}\end{array}$ & 3,070 & 501 & 85 & 404 & 917 & 54 & 463 & 25 & 24 & 12 & 144 & 441 \\
\hline $\begin{array}{l}\text { Avg. Male } \\
\text { Mortality rate } \\
\text { (SD) }\end{array}$ & $\begin{array}{c}978.60 \\
(170.41)\end{array}$ & $\begin{array}{l}1,104.78 \\
(162.36)\end{array}$ & $\begin{array}{c}890.65 \\
(149.37)\end{array}$ & $\begin{array}{c}878.01 \\
(163.74)\end{array}$ & $\begin{array}{l}1,061.39 \\
(145.96)\end{array}$ & $\begin{array}{c}825.90 \\
(111.57)\end{array}$ & $\begin{array}{c}915.49 \\
(115.73)\end{array}$ & $\begin{array}{l}1,085.76 \\
(104.52)\end{array}$ & $\begin{array}{l}777.35 \\
(75.57)\end{array}$ & $\begin{array}{c}821.78 \\
(124.75)\end{array}$ & $\begin{array}{c}978.27 \\
(153.00)\end{array}$ & $\begin{array}{l}866.39 \\
(92.63)\end{array}$ \\
\hline $\begin{array}{l}\text { Avg. Male } \\
\text { Residents } \\
\text { (SD) (in 2000) } \\
\end{array}$ & $\begin{array}{c}44,778.7 \\
(145,289.0)\end{array}$ & $\begin{array}{c}36,245.2 \\
(96,459.65)\end{array}$ & \begin{tabular}{|c|}
$163,014.6$ \\
$(579,334.5)$
\end{tabular} & \begin{tabular}{|c|}
$28,661.52$ \\
$(81,648.02)$
\end{tabular} & $\begin{array}{c}26,735.55 \\
(62,423.32)\end{array}$ & $\begin{array}{l}143,189.8 \\
(198,990.1)\end{array}$ & $\begin{array}{r}33,577.29 \\
(73,262.3)\end{array}$ & \begin{tabular}{|}
$49,109.68$ \\
$(57,812.98)$
\end{tabular} & $\begin{array}{c}382,955.4 \\
(303,467.6)\end{array}$ & $\begin{array}{c}252,910.7 \\
(358,757.7)\end{array}$ & $\begin{array}{c}40,213.32 \\
(72,628)\end{array}$ & \begin{tabular}{|c|}
$60,854.37$ \\
$(159,144.6)$
\end{tabular} \\
\hline \multicolumn{13}{|c|}{ MALE } \\
\hline \multicolumn{13}{|l|}{$\%$ Education } \\
\hline $\begin{array}{l}<\mathrm{HS} \\
(\mathrm{SD}) \\
\end{array}$ & $\begin{array}{l}23.72 \\
(9.23) \\
\end{array}$ & $\begin{array}{l}30.01 \\
(8.19) \\
\end{array}$ & $\begin{array}{c}31.97 \\
(11.27) \\
\end{array}$ & $\begin{array}{l}18.23 \\
(7.10) \\
\end{array}$ & $\begin{array}{l}27.45 \\
(8.72) \\
\end{array}$ & $\begin{array}{l}16.41 \\
(5.65) \\
\end{array}$ & $\begin{array}{l}18.43 \\
(5.69) \\
\end{array}$ & $\begin{array}{l}31.94 \\
(8.34) \\
\end{array}$ & $\begin{array}{l}17.84 \\
(7.66) \\
\end{array}$ & $\begin{array}{l}23.15 \\
(9.80) \\
\end{array}$ & $\begin{array}{l}25.83 \\
(9.47) \\
\end{array}$ & $\begin{array}{l}17.87 \\
(4.61) \\
\end{array}$ \\
\hline $\begin{array}{l}\text { HS/Some College } \\
\text { (SD) }\end{array}$ & $\begin{array}{l}59.31 \\
(7.39) \\
\end{array}$ & $\begin{array}{l}55.82 \\
(5.53) \\
\end{array}$ & $\begin{array}{l}51.63 \\
(8.32) \\
\end{array}$ & $\begin{array}{l}60.03 \\
(6.54) \\
\end{array}$ & $\begin{array}{l}58.23 \\
(6.44) \\
\end{array}$ & $\begin{array}{l}57.35 \\
(8.66) \\
\end{array}$ & $\begin{array}{l}64.33 \\
(6.49) \\
\end{array}$ & $\begin{array}{l}54.96 \\
(5.65) \\
\end{array}$ & $\begin{array}{l}47.55 \\
(7.21) \\
\end{array}$ & $\begin{array}{l}53.74 \\
(6.33) \\
\end{array}$ & $\begin{array}{l}52.88 \\
(8.03) \\
\end{array}$ & $\begin{array}{l}62.61 \\
(5.69) \\
\end{array}$ \\
\hline $\begin{array}{l}\text { 4yr College+ } \\
\text { (SD) }\end{array}$ & $\begin{array}{l}16.97 \\
(8.67)\end{array}$ & $\begin{array}{l}14.16 \\
(7.46) \\
\end{array}$ & $\begin{array}{l}16.39 \\
(7.11) \\
\end{array}$ & $\begin{array}{l}19.74 \\
(8.77) \\
\end{array}$ & $\begin{array}{l}14.32 \\
(7.20) \\
\end{array}$ & $\begin{array}{c}26.24 \\
(10.34) \\
\end{array}$ & $\begin{array}{l}17.23 \\
(7.39) \\
\end{array}$ & $\begin{array}{l}13.09 \\
(7.10) \\
\end{array}$ & $\begin{array}{l}34.61 \\
(9.78) \\
\end{array}$ & $\begin{array}{c}23.11 \\
(11.53) \\
\end{array}$ & $\begin{array}{c}21.29 \\
(12.72) \\
\end{array}$ & $\begin{array}{l}19.52 \\
(8.12) \\
\end{array}$ \\
\hline \multicolumn{13}{|l|}{$\%$ Race } \\
\hline $\begin{array}{l}\text { White } \\
\text { (SD) }\end{array}$ & $\begin{array}{c}87.61 \\
(15.29) \\
\end{array}$ & $\begin{array}{c}67.55 \\
(16.89) \\
\end{array}$ & $\begin{array}{l}93.33 \\
(5.22) \\
\end{array}$ & $\begin{array}{c}91.96 \\
(13.86) \\
\end{array}$ & $\begin{array}{l}92.72 \\
(7.56) \\
\end{array}$ & $\begin{array}{l}88.72 \\
(9.15) \\
\end{array}$ & $\begin{array}{l}94.81 \\
(8.43) \\
\end{array}$ & $\begin{array}{c}72.33 \\
(14.29) \\
\end{array}$ & $\begin{array}{c}78.17 \\
(13.96) \\
\end{array}$ & $\begin{array}{l}84.43 \\
(9.54) \\
\end{array}$ & $\begin{array}{c}69.80 \\
(16.44) \\
\end{array}$ & $\begin{array}{l}94.23 \\
(7.23) \\
\end{array}$ \\
\hline $\begin{array}{l}\text { Black } \\
\text { (SD) }\end{array}$ & $\begin{array}{c}9.10 \\
(14.35) \\
\end{array}$ & $\begin{array}{c}30.68 \\
(17.22) \\
\end{array}$ & $\begin{array}{c}2.76 \\
(3.25) \\
\end{array}$ & $\begin{array}{c}0.95 \\
(1.94) \\
\end{array}$ & $\begin{array}{c}4.65 \\
(5.86) \\
\end{array}$ & $\begin{array}{c}2.47 \\
(3.34) \\
\end{array}$ & $\begin{array}{c}2.69 \\
(5.17) \\
\end{array}$ & $\begin{array}{c}25.23 \\
(14.36) \\
\end{array}$ & $\begin{array}{c}14.09 \\
(11.82) \\
\end{array}$ & $\begin{array}{l}13.25 \\
(8.86) \\
\end{array}$ & $\begin{array}{c}27.75 \\
(16.70) \\
\end{array}$ & $\begin{array}{c}2.66 \\
(4.56) \\
\end{array}$ \\
\hline \multicolumn{13}{|l|}{$\begin{array}{l}\text { \% Health } \\
\text { Indicator }\end{array}$} \\
\hline $\begin{array}{l}\text { Obesity } \\
\text { (SD) }\end{array}$ & $\begin{array}{l}28.77 \\
(3.13) \\
\end{array}$ & $\begin{array}{l}31.08 \\
(2.80) \\
\end{array}$ & $\begin{array}{l}27.33 \\
(3.07) \\
\end{array}$ & $\begin{array}{l}26.74 \\
(3.56) \\
\end{array}$ & $\begin{array}{l}29.53 \\
(2.25) \\
\end{array}$ & $\begin{array}{l}25.26 \\
(3.35) \\
\end{array}$ & $\begin{array}{l}28.51 \\
(2.20) \\
\end{array}$ & $\begin{array}{l}30.68 \\
(2.24) \\
\end{array}$ & $\begin{array}{l}23.30 \\
(2.75) \\
\end{array}$ & $\begin{array}{l}26.76 \\
(3.36) \\
\end{array}$ & $\begin{array}{l}29.10 \\
(3.95) \\
\end{array}$ & $\begin{array}{l}27.55 \\
(2.55) \\
\end{array}$ \\
\hline $\begin{array}{l}\text { Physical Activity } \\
\text { (SD) }\end{array}$ & $\begin{array}{l}52.92 \\
(7.01) \\
\end{array}$ & $\begin{array}{l}48.83 \\
(5.71) \\
\end{array}$ & $\begin{array}{l}52.23 \\
(6.94) \\
\end{array}$ & $\begin{array}{l}57.96 \\
(5.92) \\
\end{array}$ & $\begin{array}{l}49.36 \\
(6.55) \\
\end{array}$ & $\begin{array}{l}65.15 \\
(3.89) \\
\end{array}$ & $\begin{array}{l}53.52 \\
(4.11) \\
\end{array}$ & $\begin{array}{l}45.34 \\
(4.56) \\
\end{array}$ & $\begin{array}{l}54.41 \\
(5.61) \\
\end{array}$ & $\begin{array}{l}55.21 \\
(6.91) \\
\end{array}$ & $\begin{array}{l}53.94 \\
(6.33) \\
\end{array}$ & $\begin{array}{l}58.31 \\
(4.29) \\
\end{array}$ \\
\hline $\begin{array}{l}\text { Smoking } \\
\text { (SD) }\end{array}$ & $\begin{array}{l}23.29 \\
(3.87) \\
\end{array}$ & $\begin{array}{l}24.21 \\
(2.52) \\
\end{array}$ & $\begin{array}{l}18.76 \\
(2.11) \\
\end{array}$ & $\begin{array}{l}19.87 \\
(2.90) \\
\end{array}$ & $\begin{array}{l}25.84 \\
(3.92) \\
\end{array}$ & $\begin{array}{l}19.23 \\
(2.94) \\
\end{array}$ & $\begin{array}{l}22.97 \\
(2.98) \\
\end{array}$ & $\begin{array}{l}26.39 \\
(2.30)\end{array}$ & $\begin{array}{l}17.25 \\
(1.74) \\
\end{array}$ & $\begin{array}{l}22.17 \\
(3.44) \\
\end{array}$ & $\begin{array}{l}23.31 \\
(3.39) \\
\end{array}$ & $\begin{array}{l}21.94 \\
(2.44) \\
\end{array}$ \\
\hline \multicolumn{13}{|l|}{ Labor Force } \\
\hline $\begin{array}{l}\text { Unemployment } \\
\text { rate (SD) }\end{array}$ & $\begin{array}{c}57.43 \\
(29.75) \\
\end{array}$ & $\begin{array}{c}62.52 \\
(26.52) \\
\end{array}$ & $\begin{array}{c}83.22 \\
(35.98) \\
\end{array}$ & $\begin{array}{c}64.17 \\
(43.48) \\
\end{array}$ & $\begin{array}{l}55.45 \\
(24.11) \\
\end{array}$ & $\begin{array}{c}67.23 \\
(22.27) \\
\end{array}$ & $\begin{array}{l}42.76 \\
(22.22) \\
\end{array}$ & $\begin{array}{c}66.12 \\
(16.44) \\
\end{array}$ & $\begin{array}{l}56.78 \\
(27.49) \\
\end{array}$ & $\begin{array}{c}54.53 \\
(19.68) \\
\end{array}$ & $\begin{array}{c}51.19 \\
(38.30) \\
\end{array}$ & $\begin{array}{c}60.49 \\
(24.33) \\
\end{array}$ \\
\hline
\end{tabular}

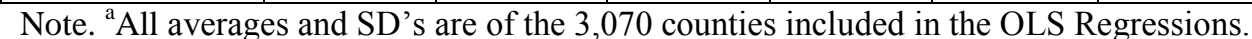

(no Alaska or Hawaii; counties/cities missing mortality data were: Alpine, CA, Arthur, NE, Banner, NE, Billings, ND, Blaine, NE, Borden, TX, Camas, ID,

Clark, ID, Daggett, UT, Glasscock, TX, Grant, NE, Harding, NM, Hayes, NE, Hinsdale, CO, Jones, SD, Kenedy, TX, Keya Paha, NE, King, TX, Logan, NE,

Loupe, NE, Loving, TX, McMullen, TX, McPherson, NE, Mineral, CO, Petroleum, MT, Roberts, TX, San Juan, CO, Sioux, NE, Slope, ND, Sully, SD, Thomas, NE, Treasure, MT, Wheeler, NE; counties missing data on mediators: Bedford City, VA, Broomfield, CO, Clifton Forge City, VA, Fairfax City, VA, Franklin City, VA, Manassas Park City, VA, Waynesboro City, VA) 
Table 4c. Descriptives of Woodard's American Nations - Female

\begin{tabular}{|c|c|c|c|c|c|c|c|c|c|c|c|c|}
\hline Variable & USA & $\begin{array}{l}\text { Deep } \\
\text { South }\end{array}$ & El Norte & Far West & $\begin{array}{c}\text { Greater } \\
\text { Appalachia }\end{array}$ & $\begin{array}{c}\text { Left } \\
\text { Coast }\end{array}$ & Midlands & $\begin{array}{c}\text { New } \\
\text { France }\end{array}$ & $\begin{array}{c}\text { New } \\
\text { Netherlands }\end{array}$ & $\begin{array}{c}\text { Spanish } \\
\text { Caribbean }\end{array}$ & Tidewater & Yankeedom \\
\hline \# of counties & 3,109 & 501 & 87 & 429 & 922 & 54 & 465 & 25 & 24 & 12 & 149 & 441 \\
\hline $\begin{array}{l}\text { \# of counties } \\
\text { included in OLS } \\
\text { Regressions } \mathrm{s}^{\mathrm{a}}\end{array}$ & 3,070 & 501 & 85 & 404 & 917 & 54 & 463 & 25 & 24 & 12 & 144 & 441 \\
\hline $\begin{array}{l}\text { Avg. Female } \\
\text { Mortality rate } \\
\text { (SD) } \\
\end{array}$ & $\begin{array}{c}701.45 \\
(119.71)\end{array}$ & $\begin{array}{l}782.73 \\
(99.63)\end{array}$ & $\begin{array}{l}619.58 \\
(99.73)\end{array}$ & $\begin{array}{c}640.07 \\
(120.78)\end{array}$ & $\begin{array}{c}765.89 \\
(102.30)\end{array}$ & $\begin{array}{l}603.47 \\
(82.92)\end{array}$ & $\begin{array}{l}653.56 \\
(93.70)\end{array}$ & $\begin{array}{l}776.97 \\
(88.22)\end{array}$ & $\begin{array}{l}554.76 \\
(46.79)\end{array}$ & $\begin{array}{c}588.88 \\
(126.34)\end{array}$ & $\begin{array}{l}692.77 \\
(86.99)\end{array}$ & $\begin{array}{l}619.00 \\
(70.59)\end{array}$ \\
\hline $\begin{array}{l}\text { Avg. Female } \\
\text { Residents } \\
\text { (SD) (in 2000) }\end{array}$ & $\begin{array}{c}46,508.37 \\
(150,864.3)\end{array}$ & $\mid \begin{array}{c}37,743.21 \\
(99,048.81)\end{array}$ & $\begin{array}{c}165,469.8 \\
(590,212.1)\end{array}$ & $\begin{array}{c}28558.14 \\
(81,629.63)\end{array}$ & $\begin{array}{c}27687.33 \\
(64,287.49)\end{array}$ & $\begin{array}{c}144408.9 \\
(200081.4)\end{array}$ & $\mid \begin{array}{c}35,423.58 \\
(80,085.25)\end{array}$ & \begin{tabular}{|c}
$52,527.76$ \\
$(64,137.46)$
\end{tabular} & $\begin{array}{c}414,478.8 \\
(33,7130.7)\end{array}$ & $\begin{array}{c}269,257.8 \\
(384,420.8)\end{array}$ & $\begin{array}{c}42,445.15 \\
(76,870.41)\end{array}$ & $\begin{array}{c}63,665.68 \\
(169,862.5)\end{array}$ \\
\hline \multicolumn{13}{|c|}{ FEMALE } \\
\hline \multicolumn{13}{|l|}{ \% Education } \\
\hline $\begin{array}{l}<\mathrm{HS} \\
(\mathrm{SD}) \\
\end{array}$ & $\begin{array}{l}21.78 \\
(8.41) \\
\end{array}$ & $\begin{array}{l}27.98 \\
(6.79) \\
\end{array}$ & $\begin{array}{c}32.12 \\
(11.79) \\
\end{array}$ & $\begin{array}{l}16.20 \\
(6.12) \\
\end{array}$ & $\begin{array}{l}25.59 \\
(7.38) \\
\end{array}$ & $\begin{array}{l}14.97 \\
(4.33) \\
\end{array}$ & $\begin{array}{l}16.89 \\
(5.18) \\
\end{array}$ & $\begin{array}{l}28.85 \\
(6.85) \\
\end{array}$ & $\begin{array}{l}18.09 \\
(7.77) \\
\end{array}$ & $\begin{array}{l}20.20 \\
(7.49) \\
\end{array}$ & $\begin{array}{l}22.55 \\
(7.36) \\
\end{array}$ & $\begin{array}{l}15.49 \\
(3.62) \\
\end{array}$ \\
\hline $\begin{array}{l}\text { HS/Some } \\
\text { College } \\
\text { (SD) }\end{array}$ & $\begin{array}{l}62.20 \\
(6.87)\end{array}$ & $\begin{array}{l}58.11 \\
(4.68)\end{array}$ & $\begin{array}{l}52.70 \\
(8.80)\end{array}$ & $\begin{array}{l}65.55 \\
(6.26)\end{array}$ & $\begin{array}{l}60.96 \\
(5.57)\end{array}$ & $\begin{array}{l}61.80 \\
(8.50)\end{array}$ & $\begin{array}{l}66.63 \\
(5.68)\end{array}$ & $\begin{array}{l}58.10 \\
(4.73)\end{array}$ & $\begin{array}{l}51.73 \\
(6.90)\end{array}$ & $\begin{array}{l}60.69 \\
(6.26)\end{array}$ & $\begin{array}{l}57.46 \\
(6.68)\end{array}$ & $\begin{array}{l}65.97 \\
(5.27)\end{array}$ \\
\hline $\begin{array}{l}\text { 4yr College+ } \\
\text { (SD) }\end{array}$ & $\begin{array}{l}16.02 \\
(7.13)\end{array}$ & $\begin{array}{l}13.91 \\
(5.58)\end{array}$ & $\begin{array}{l}15.18 \\
(5.86)\end{array}$ & $\begin{array}{l}18.25 \\
(7.77)\end{array}$ & $\begin{array}{l}13.45 \\
(5.59)\end{array}$ & $\begin{array}{l}23.23 \\
(9.27)\end{array}$ & $\begin{array}{l}16.48 \\
(6.10)\end{array}$ & $\begin{array}{l}13.05 \\
(5.11)\end{array}$ & $\begin{array}{l}30.19 \\
(8.18)\end{array}$ & $\begin{array}{l}19.11 \\
(9.18)\end{array}$ & $\begin{array}{c}19.99 \\
(10.06)\end{array}$ & $\begin{array}{l}18.54 \\
(7.00)\end{array}$ \\
\hline \multicolumn{13}{|l|}{ \% Race } \\
\hline $\begin{array}{l}\text { White } \\
\text { (SD) }\end{array}$ & $\begin{array}{c}87.71 \\
(15.97) \\
\end{array}$ & $\begin{array}{c}66.45 \\
(17.78) \\
\end{array}$ & $\begin{array}{l}94.23 \\
(5.15)\end{array}$ & $\begin{array}{c}92.07 \\
(14.14)\end{array}$ & $\begin{array}{l}93.21 \\
(7.71)\end{array}$ & $\begin{array}{l}88.54 \\
(9.75)\end{array}$ & $\begin{array}{l}95.27 \\
(8.56)\end{array}$ & $\begin{array}{c}71.65 \\
(14.93)\end{array}$ & $\begin{array}{c}77.50 \\
(14.64)\end{array}$ & $\begin{array}{l}85.64 \\
(9.49)\end{array}$ & $\begin{array}{c}69.01 \\
(16.85)\end{array}$ & $\begin{array}{l}94.79 \\
(7.24)\end{array}$ \\
\hline $\begin{array}{l}\text { Black } \\
\text { (SD) }\end{array}$ & $\begin{array}{c}8.93 \\
(15.05) \\
\end{array}$ & $\begin{array}{c}31.78 \\
(18.12)\end{array}$ & $\begin{array}{c}1.72 \\
(2.06)\end{array}$ & $\begin{array}{c}0.58 \\
(1.38) \\
\end{array}$ & $\begin{array}{c}4.16 \\
(6.03)\end{array}$ & $\begin{array}{c}2.03 \\
(3.41)\end{array}$ & $\begin{array}{c}2.22 \\
(5.20)\end{array}$ & $\begin{array}{c}26.05 \\
(15.00) \\
\end{array}$ & $\begin{array}{c}15.08 \\
(12.78)\end{array}$ & $\begin{array}{l}12.17 \\
(8.81)\end{array}$ & $\begin{array}{c}28.48 \\
(17.09)\end{array}$ & $\begin{array}{c}2.07 \\
(4.62)\end{array}$ \\
\hline \multicolumn{13}{|l|}{$\%$ Health Indicator } \\
\hline $\begin{array}{l}\text { Obesity } \\
\text { (SD) }\end{array}$ & $\begin{array}{l}31.35 \\
(5.05) \\
\end{array}$ & $\begin{array}{l}36.88 \\
(5.49) \\
\end{array}$ & $\begin{array}{l}33.42 \\
(5.50) \\
\end{array}$ & $\begin{array}{l}28.08 \\
(4.54) \\
\end{array}$ & $\begin{array}{l}31.65 \\
(3.04) \\
\end{array}$ & $\begin{array}{l}28.06 \\
(4.06) \\
\end{array}$ & $\begin{array}{l}29.71 \\
(2.70) \\
\end{array}$ & $\begin{array}{l}35.43 \\
(3.95) \\
\end{array}$ & $\begin{array}{l}24.74 \\
(4.57) \\
\end{array}$ & $\begin{array}{l}37.31 \\
(4.71) \\
\end{array}$ & $\begin{array}{l}33.73 \\
(6.74) \\
\end{array}$ & $\begin{array}{l}28.60 \\
(3.11) \\
\end{array}$ \\
\hline $\begin{array}{l}\text { Physical Activity } \\
\text { (SD) }\end{array}$ & $\begin{array}{l}43.86 \\
(7.98) \\
\end{array}$ & $\begin{array}{l}36.90 \\
(5.87) \\
\end{array}$ & $\begin{array}{l}43.85 \\
(6.96) \\
\end{array}$ & $\begin{array}{l}52.05 \\
(5.34) \\
\end{array}$ & $\begin{array}{l}39.53 \\
(6.18) \\
\end{array}$ & $\begin{array}{l}57.42 \\
(4.44) \\
\end{array}$ & $\begin{array}{l}46.01 \\
(3.53) \\
\end{array}$ & $\begin{array}{l}34.21 \\
(4.35) \\
\end{array}$ & $\begin{array}{l}45.08 \\
(6.04) \\
\end{array}$ & $\begin{array}{l}45.23 \\
(5.56) \\
\end{array}$ & $\begin{array}{l}41.56 \\
(7.26) \\
\end{array}$ & $\begin{array}{l}50.53 \\
(4.26) \\
\end{array}$ \\
\hline $\begin{array}{l}\text { Smoking } \\
\text { (SD) }\end{array}$ & $\begin{array}{l}19.92 \\
(3.78) \\
\end{array}$ & $\begin{array}{l}19.38 \\
(2.53) \\
\end{array}$ & $\begin{array}{l}14.42 \\
(2.89) \\
\end{array}$ & $\begin{array}{l}17.75 \\
(3.38) \\
\end{array}$ & $\begin{array}{l}22.66 \\
(3.69) \\
\end{array}$ & $\begin{array}{l}16.17 \\
(4.07) \\
\end{array}$ & $\begin{array}{l}19.61 \\
(2.88) \\
\end{array}$ & $\begin{array}{l}20.93 \\
(2.88) \\
\end{array}$ & $\begin{array}{l}15.40 \\
(1.94) \\
\end{array}$ & $\begin{array}{l}18.96 \\
(3.97) \\
\end{array}$ & $\begin{array}{l}18.57 \\
(3.15) \\
\end{array}$ & $\begin{array}{l}19.30 \\
(2.65) \\
\end{array}$ \\
\hline \multicolumn{13}{|l|}{ Labor Force } \\
\hline $\begin{array}{l}\text { Unemployment } \\
\text { rate (SD) }\end{array}$ & $\begin{array}{c}57.70 \\
(28.10) \\
\end{array}$ & $\begin{array}{c}77.48 \\
(27.45) \\
\end{array}$ & $\begin{array}{c}82.51 \\
(34.36) \\
\end{array}$ & $\begin{array}{c}57.44 \\
(34.90) \\
\end{array}$ & $\begin{array}{c}57.84 \\
(21.72) \\
\end{array}$ & $\begin{array}{c}62.49 \\
(15.92)\end{array}$ & $\begin{array}{c}41.17 \\
(19.01)\end{array}$ & $\begin{array}{l}78.04 \\
(22.16)\end{array}$ & $\begin{array}{c}59.71 \\
(30.36) \\
\end{array}$ & $\begin{array}{c}54.19 \\
(20.89) \\
\end{array}$ & $\begin{array}{c}58.00 \\
(38.62)\end{array}$ & $\begin{array}{c}45.91 \\
(18.15)\end{array}$ \\
\hline
\end{tabular}

Note. ${ }^{a}$ All averages and SD's are of the 3,070 counties included in the OLS Regressions.

(no Alaska or Hawaii; counties/cities missing mortality data were: Alpine, CA, Arthur, NE, Banner, NE, Billings, ND, Blaine, NE, Borden, TX, Camas, ID,

Clark, ID, Daggett, UT, Glasscock, TX, Grant, NE, Harding, NM, Hayes, NE, Hinsdale, CO, Jones, SD, Kenedy, TX, Keya Paha, NE, King, TX, Logan, NE,

Loupe, NE, Loving, TX, McMullen, TX, McPherson, NE, Mineral, CO, Petroleum, MT, Roberts, TX, San Juan, CO, Sioux, NE, Slope, ND, Sully, SD, Thomas, NE, Treasure, MT, Wheeler, NE; counties missing data on mediators: Bedford City, VA, Broomfield, CO, Clifton Forge City, VA, Fairfax City, VA, Franklin

City, VA, Manassas Park City, VA, Waynesboro City, VA) 
Table 5a. Descriptives of Garreau's Nine Nations

\begin{tabular}{|c|c|c|c|c|c|c|c|c|c|}
\hline Variable & USA & $\begin{array}{c}\text { The } \\
\text { Empty } \\
\text { Quarter }\end{array}$ & Ecotopia & $\begin{array}{c}\text { The } \\
\text { Bread- } \\
\text { basket }\end{array}$ & $\begin{array}{c}\text { Mex- } \\
\text { America }\end{array}$ & $\begin{array}{c}\text { New } \\
\text { England }\end{array}$ & $\begin{array}{c}\text { The } \\
\text { Foundry }\end{array}$ & Dixie & $\begin{array}{l}\text { The } \\
\text { Islands }\end{array}$ \\
\hline$\#$ of counties & 3,109 & 236 & 61 & 953 & 141 & 66 & 426 & 1,219 & 7 \\
\hline $\begin{array}{l}\text { \# of counties } \\
\text { included in OLS }\end{array}$ & 3,070 & 229 & 61 & 931 & 136 & 66 & 424 & 1,216 & 7 \\
\hline \multicolumn{10}{|l|}{ \# of RUCCS (\%) } \\
\hline 1 & $\begin{array}{c}411 \\
(13.39) \\
\end{array}$ & $\begin{array}{c}9 \\
(3.93) \\
\end{array}$ & $\begin{array}{c}14 \\
(22.95) \\
\end{array}$ & $\begin{array}{c}65 \\
(6.98)\end{array}$ & $\begin{array}{c}30 \\
(22.06)\end{array}$ & $\begin{array}{c}16 \\
(24.24)\end{array}$ & $\begin{array}{c}108 \\
(25.47)\end{array}$ & $\begin{array}{c}166 \\
(13.65)\end{array}$ & $\begin{array}{c}3 \\
(42.86)\end{array}$ \\
\hline 2 & $\begin{array}{c}322 \\
(10.49)\end{array}$ & $\begin{array}{c}18 \\
(7.86)\end{array}$ & $\begin{array}{c}7 \\
(11.48) \\
\end{array}$ & $\begin{array}{c}47 \\
(5.05)\end{array}$ & $\begin{array}{c}19 \\
(13.97)\end{array}$ & $\begin{array}{c}10 \\
(15.15)\end{array}$ & $\begin{array}{c}65 \\
(15.33)\end{array}$ & $\begin{array}{c}154 \\
(12.66)\end{array}$ & $\begin{array}{c}2 \\
(28.57)\end{array}$ \\
\hline 3 & $\begin{array}{c}349 \\
(11.37) \\
\end{array}$ & $\begin{array}{c}25 \\
(10.92) \\
\end{array}$ & $\begin{array}{c}13 \\
(21.31) \\
\end{array}$ & $\begin{array}{c}96 \\
(10.31) \\
\end{array}$ & $\begin{array}{c}12 \\
(8.82) \\
\end{array}$ & $\begin{array}{c}7 \\
(10.61) \\
\end{array}$ & $\begin{array}{c}53 \\
(12.50) \\
\end{array}$ & $\begin{array}{c}143 \\
(11.76) \\
\end{array}$ & 0 \\
\hline 4 & $\begin{array}{c}217 \\
(7.07) \\
\end{array}$ & $\begin{array}{c}13 \\
(5.68) \\
\end{array}$ & $\begin{array}{c}11 \\
(18.03) \\
\end{array}$ & $\begin{array}{c}34 \\
(3.65) \\
\end{array}$ & $\begin{array}{c}13 \\
(9.56) \\
\end{array}$ & $\begin{array}{c}7 \\
(10.61) \\
\end{array}$ & $\begin{array}{c}57 \\
(13.44) \\
\end{array}$ & $\begin{array}{c}80 \\
(6.58) \\
\end{array}$ & $\begin{array}{c}2 \\
(28.57) \\
\end{array}$ \\
\hline 5 & $\begin{array}{c}101 \\
(3.29)\end{array}$ & $\begin{array}{c}12 \\
(5.24)\end{array}$ & $\begin{array}{c}3 \\
(4.92)\end{array}$ & $\begin{array}{c}43 \\
(4.62)\end{array}$ & $\begin{array}{c}2 \\
(1.47)\end{array}$ & $\begin{array}{c}2 \\
(3.03)\end{array}$ & $\begin{array}{c}8 \\
(1.89)\end{array}$ & $\begin{array}{c}31 \\
(2.55)\end{array}$ & 0 \\
\hline 6 & $\begin{array}{c}607 \\
(19.77)\end{array}$ & $\begin{array}{c}39 \\
(17.03)\end{array}$ & $\begin{array}{c}6 \\
(9.84)\end{array}$ & $\begin{array}{c}167 \\
(17.94)\end{array}$ & $\begin{array}{c}28 \\
(20.59)\end{array}$ & $\begin{array}{c}8 \\
(12.12)\end{array}$ & $\begin{array}{c}78 \\
(18.40)\end{array}$ & $\begin{array}{c}281 \\
(23.11)\end{array}$ & 0 \\
\hline 7 & $\begin{array}{c}440 \\
(14.33)\end{array}$ & $\begin{array}{c}53 \\
(23.14) \\
\end{array}$ & $\begin{array}{c}4 \\
(6.56) \\
\end{array}$ & $\begin{array}{c}172 \\
(18.47) \\
\end{array}$ & $\begin{array}{c}17 \\
(12.50) \\
\end{array}$ & $\begin{array}{c}10 \\
(15.15) \\
\end{array}$ & $\begin{array}{c}35 \\
(8.25) \\
\end{array}$ & $\begin{array}{c}149 \\
(12.25) \\
\end{array}$ & 0 \\
\hline 8 & $\begin{array}{c}226 \\
(7.36)\end{array}$ & $\begin{array}{c}22 \\
(9.61)\end{array}$ & $\begin{array}{c}2 \\
(3.28) \\
\end{array}$ & $\begin{array}{c}81 \\
(8.70)\end{array}$ & $\begin{array}{c}5 \\
(3.68) \\
\end{array}$ & $\begin{array}{c}4 \\
(6.06) \\
\end{array}$ & $\begin{array}{c}9 \\
(2.12)\end{array}$ & $\begin{array}{c}103 \\
(8.47)\end{array}$ & 0 \\
\hline 9 & $\begin{array}{c}397 \\
(12.93)\end{array}$ & $\begin{array}{c}38 \\
(16.59) \\
\end{array}$ & $\begin{array}{c}1 \\
(1.64)\end{array}$ & $\begin{array}{c}226 \\
(24.27)\end{array}$ & $\begin{array}{c}10 \\
(7.35)\end{array}$ & $\begin{array}{c}2 \\
(3.03)\end{array}$ & $\begin{array}{c}11 \\
(2.59)\end{array}$ & $\begin{array}{c}109 \\
(8.96)\end{array}$ & 0 \\
\hline \multicolumn{10}{|l|}{ \# Typology $(\%)$} \\
\hline Non-dependent & $\begin{array}{c}936 \\
(30.49)\end{array}$ & $\begin{array}{c}61 \\
(26.64)\end{array}$ & $\begin{array}{c}29 \\
(47.54)\end{array}$ & $\begin{array}{c}331 \\
(35.55)\end{array}$ & $\begin{array}{c}53 \\
(38.97)\end{array}$ & $\begin{array}{c}17 \\
(25.76)\end{array}$ & $\begin{array}{c}95 \\
(22.41)\end{array}$ & $\begin{array}{c}350 \\
(28.78)\end{array}$ & 0 \\
\hline Farming & $\begin{array}{c}413 \\
(13.45) \\
\end{array}$ & $\begin{array}{c}46 \\
(20.09) \\
\end{array}$ & $\begin{array}{c}2 \\
(3.28) \\
\end{array}$ & $\begin{array}{c}272 \\
(29.22) \\
\end{array}$ & $\begin{array}{c}11 \\
(8.09) \\
\end{array}$ & 0 & 0 & $\begin{array}{c}81 \\
(6.66) \\
\end{array}$ & $\begin{array}{c}1 \\
(14.29) \\
\end{array}$ \\
\hline Mining & $\begin{array}{c}125 \\
(4.07) \\
\end{array}$ & $\begin{array}{c}28 \\
(12.23) \\
\end{array}$ & 0 & $\begin{array}{c}33 \\
(3.54)\end{array}$ & $\begin{array}{c}7 \\
(5.15)\end{array}$ & 0 & $\begin{array}{c}6 \\
(1.42) \\
\end{array}$ & $\begin{array}{c}51 \\
(4.19)\end{array}$ & 0 \\
\hline Manufacturing & $\begin{array}{c}898 \\
(29.25)\end{array}$ & $\begin{array}{c}12 \\
(5.24)\end{array}$ & $\begin{array}{c}8 \\
(13.11)\end{array}$ & $\begin{array}{c}178 \\
(19.12)\end{array}$ & $\begin{array}{c}7 \\
(5.15)\end{array}$ & $\begin{array}{c}16 \\
(24.24)\end{array}$ & $\begin{array}{c}209 \\
(49.29)\end{array}$ & $\begin{array}{c}468 \\
(38.49)\end{array}$ & 0 \\
\hline Government & $\begin{array}{c}367 \\
(11.95)\end{array}$ & $\begin{array}{c}41 \\
(17.90)\end{array}$ & $\begin{array}{c}10 \\
(16.39)\end{array}$ & $\begin{array}{c}77 \\
(8.27)\end{array}$ & $\begin{array}{c}38 \\
(27.94)\end{array}$ & $\begin{array}{c}5 \\
(7.58)\end{array}$ & $\begin{array}{c}36 \\
(8.49)\end{array}$ & $\begin{array}{c}160 \\
(13.16)\end{array}$ & 0 \\
\hline Service & $\begin{array}{c}331 \\
(10.78)\end{array}$ & $\begin{array}{c}41 \\
(17.90)\end{array}$ & $\begin{array}{c}12 \\
(19.67)\end{array}$ & $\begin{array}{c}40 \\
(4.30)\end{array}$ & $\begin{array}{c}20 \\
(14.71)\end{array}$ & $\begin{array}{c}28 \\
(42.42) \\
\end{array}$ & $\begin{array}{c}78 \\
(18.40) \\
\end{array}$ & $\begin{array}{c}106 \\
(8.72)\end{array}$ & $\begin{array}{c}6 \\
(85.71) \\
\end{array}$ \\
\hline \multicolumn{10}{|l|}{ Medical Care } \\
\hline $\begin{array}{l}\text { Active MD rate } \\
\text { (SD) }\end{array}$ & $\begin{array}{c}1.20 \\
(1.34)\end{array}$ & $\begin{array}{c}1.15 \\
(0.87)\end{array}$ & $\begin{array}{c}1.89 \\
(1.14)\end{array}$ & $\begin{array}{c}0.95 \\
(1.18)\end{array}$ & $\begin{array}{c}1.20 \\
(0.92)\end{array}$ & $\begin{array}{c}2.57 \\
(1.76)\end{array}$ & $\begin{array}{c}1.68 \\
(1.74)\end{array}$ & $\begin{array}{c}1.12 \\
(1.29)\end{array}$ & $\begin{array}{l}2.17 \\
(0.87)\end{array}$ \\
\hline $\begin{array}{l}\text { Hospital Bed rate } \\
\text { (SD) }\end{array}$ & $\begin{array}{c}3.89 \\
(5.15) \\
\end{array}$ & $\begin{array}{c}4.41 \\
(5.13) \\
\end{array}$ & $\begin{array}{c}2.19 \\
(2.09) \\
\end{array}$ & $\begin{array}{c}5.19 \\
(6.41) \\
\end{array}$ & $\begin{array}{c}2.03 \\
(2.16) \\
\end{array}$ & $\begin{array}{c}2.79 \\
(1.66) \\
\end{array}$ & $\begin{array}{c}3.34 \\
(4.94) \\
\end{array}$ & $\begin{array}{c}3.35 \\
(4.35) \\
\end{array}$ & $\begin{array}{c}3.07 \\
(1.13) \\
\end{array}$ \\
\hline $\begin{array}{l}\text { \% No Health } \\
\text { Insurance } \\
\text { (SD) }\end{array}$ & $\begin{array}{l}14.68 \\
(4.93)\end{array}$ & $\begin{array}{l}17.60 \\
(3.85)\end{array}$ & $\begin{array}{l}15.31 \\
(3.32)\end{array}$ & $\begin{array}{l}13.64 \\
(5.17)\end{array}$ & $\begin{array}{l}22.24 \\
(6.03)\end{array}$ & $\begin{array}{c}9.31 \\
(2.08)\end{array}$ & $\begin{array}{l}10.94 \\
(2.41)\end{array}$ & $\begin{array}{l}15.63 \\
(3.88)\end{array}$ & $\begin{array}{c}16.7 \\
(4.33)\end{array}$ \\
\hline \multicolumn{10}{|l|}{ Inequality } \\
\hline $\begin{array}{l}\text { Gini } \\
\text { (SD) }\end{array}$ & $\begin{array}{l}43.45 \\
(3.85) \\
\end{array}$ & $\begin{array}{l}42.09 \\
(3.10) \\
\end{array}$ & $\begin{array}{l}43.49 \\
(3.04) \\
\end{array}$ & $\begin{array}{l}42.00 \\
(3.36) \\
\end{array}$ & $\begin{array}{l}45.38 \\
(2.93)\end{array}$ & $\begin{array}{l}42.62 \\
(2.30) \\
\end{array}$ & $\begin{array}{l}41.71 \\
(3.25) \\
\end{array}$ & $\begin{array}{l}45.23 \\
(3.86) \\
\end{array}$ & $\begin{array}{l}48.35 \\
(2.51)\end{array}$ \\
\hline
\end{tabular}

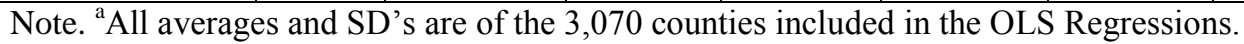

(no Alaska or Hawaii; counties/cities missing mortality data were: Alpine, CA, Arthur, NE, Banner, NE, Billings,

ND, Blaine, NE, Borden, TX, Camas, ID, Clark, ID, Daggett, UT, Glasscock, TX, Grant, NE, Harding, NM, Hayes,

NE, Hinsdale, CO, Jones, SD, Kenedy, TX, Keya Paha, NE, King, TX, Logan, NE, Loupe, NE, Loving, TX,

McMullen, TX, McPherson, NE, Mineral, CO, Petroleum, MT, Roberts, TX, San Juan, CO, Sioux, NE, Slope, ND,

Sully, SD, Thomas, NE, Treasure, MT, Wheeler, NE; counties missing data on mediators: Bedford City, VA,

Broomfield, CO, Clifton Forge City, VA, Fairfax City, VA, Franklin City, VA, Manassas Park City, VA,

Waynesboro City, VA) 
Table 5b. Descriptives of Garreau's Nine Nations - Male

\begin{tabular}{|c|c|c|c|c|c|c|c|c|c|}
\hline Variable & USA & $\begin{array}{l}\text { The Empty } \\
\text { Quarter }\end{array}$ & Ecotopia & $\begin{array}{c}\text { The } \\
\text { Breadbasket }\end{array}$ & MexAmerica & $\begin{array}{c}\text { New } \\
\text { England }\end{array}$ & $\begin{array}{c}\text { The } \\
\text { Foundry }\end{array}$ & Dixie & The Islands \\
\hline$\#$ of counties & 3,109 & 236 & 61 & 953 & 141 & 66 & 426 & 1,219 & 7 \\
\hline $\begin{array}{l}\text { \# of counties included in } \\
\text { OLS Regressions }{ }^{\mathrm{a}}\end{array}$ & $\mathbf{3 , 0 7 0}$ & 229 & 61 & 931 & 136 & 66 & 424 & 1,216 & 7 \\
\hline $\begin{array}{l}\text { Avg. Male Mortality rate } \\
\text { (SD) }\end{array}$ & $\begin{array}{c}978.60 \\
(170.41) \\
\end{array}$ & $\begin{array}{c}859.66 \\
(149.01) \\
\end{array}$ & $\begin{array}{c}850.26 \\
(113.26) \\
\end{array}$ & $\begin{array}{c}920.62 \\
(141.49) \\
\end{array}$ & $\begin{array}{c}865.52 \\
(147.21) \\
\end{array}$ & $\begin{array}{l}851.12 \\
(73.90) \\
\end{array}$ & $\begin{array}{c}930.03 \\
(112.80) \\
\end{array}$ & $\begin{array}{l}1,089.55 \\
(155.77) \\
\end{array}$ & $\begin{array}{l}765.54 \\
(97.42) \\
\end{array}$ \\
\hline $\begin{array}{l}\text { Avg. \# Male } \\
\text { (SD) (in 2000) }\end{array}$ & $\begin{array}{c}44,778.7 \\
(145,289.0) \\
\end{array}$ & $\begin{array}{c}26,393.73 \\
(66,565.62) \\
\end{array}$ & $\begin{array}{r}100,919.9 \\
(139,357.4) \\
\end{array}$ & $\begin{array}{c}20,088.41 \\
(50,803.79) \\
\end{array}$ & $\begin{array}{c}164,527.4 \\
(494,438.5) \\
\end{array}$ & $\begin{array}{c}95,843.48 \\
(132,181.9) \\
\end{array}$ & $\begin{array}{r}94,445.74 \\
(192,868.6) \\
\end{array}$ & $\begin{array}{c}28,768.99 \\
(57,887.31) \\
\end{array}$ & $\begin{array}{r}405,485.9 \\
(415,099.9) \\
\end{array}$ \\
\hline \multicolumn{10}{|c|}{ MALE } \\
\hline \multicolumn{10}{|l|}{$\%$ Education } \\
\hline $\begin{array}{l}\mathrm{HS} \\
(\mathrm{SD}) \\
\end{array}$ & $\begin{array}{l}23.72 \\
(9.23) \\
\end{array}$ & $\begin{array}{l}17.11 \\
(6.87) \\
\end{array}$ & $\begin{array}{l}17.65 \\
(6.70) \\
\end{array}$ & $\begin{array}{l}19.98 \\
(6.84) \\
\end{array}$ & $\begin{array}{l}27.70 \\
(11.47) \\
\end{array}$ & $\begin{array}{l}16.14 \\
(4.61) \\
\end{array}$ & $\begin{array}{l}19.22 \\
(5.53) \\
\end{array}$ & $\begin{array}{l}29.65 \\
(8.55) \\
\end{array}$ & $\begin{array}{c}24.97 \\
(13.37) \\
\end{array}$ \\
\hline $\begin{array}{l}\text { HS/Some College } \\
(\mathrm{SD})\end{array}$ & $\begin{array}{l}59.31 \\
(7.39) \\
\end{array}$ & $\begin{array}{l}61.64 \\
(6.50) \\
\end{array}$ & $\begin{array}{l}58.39 \\
(7.84) \\
\end{array}$ & $\begin{array}{l}63.21 \\
(6.15) \\
\end{array}$ & $\begin{array}{l}52.80 \\
(8.09) \\
\end{array}$ & $\begin{array}{l}56.78 \\
(5.60) \\
\end{array}$ & $\begin{array}{l}61.28 \\
(8.29) \\
\end{array}$ & $\begin{array}{l}56.16 \\
(5.95) \\
\end{array}$ & $\begin{array}{l}50.30 \\
(6.85) \\
\end{array}$ \\
\hline $\begin{array}{l}\text { 4yr College+ } \\
\text { (SD) }\end{array}$ & $\begin{array}{l}16.97 \\
(8.67) \\
\end{array}$ & $\begin{array}{l}21.25 \\
(9.24) \\
\end{array}$ & $\begin{array}{c}23.95 \\
(10.05) \\
\end{array}$ & $\begin{array}{l}16.81 \\
(6.37) \\
\end{array}$ & $\begin{array}{c}19.50 \\
(10.14) \\
\end{array}$ & $\begin{array}{l}27.09 \\
(8.42) \\
\end{array}$ & $\begin{array}{l}19.50 \\
(1.60) \\
\end{array}$ & $\begin{array}{l}14.18 \\
(7.78) \\
\end{array}$ & $\begin{array}{l}24.73 \\
(8.05) \\
\end{array}$ \\
\hline \multicolumn{10}{|l|}{$\%$ Race } \\
\hline $\begin{array}{l}\text { White } \\
\text { (SD) }\end{array}$ & $\begin{array}{c}87.61 \\
(15.29) \\
\end{array}$ & $\begin{array}{l}92.75 \\
(11.87) \\
\end{array}$ & $\begin{array}{l}89.91 \\
(7.15) \\
\end{array}$ & $\begin{array}{l}93.80 \\
(10.24) \\
\end{array}$ & $\begin{array}{l}90.71 \\
(7.99) \\
\end{array}$ & $\begin{array}{l}94.92 \\
(5.19) \\
\end{array}$ & $\begin{array}{l}91.67 \\
(9.78) \\
\end{array}$ & $\begin{array}{c}79.63 \\
(18.19) \\
\end{array}$ & $\begin{array}{l}84.87 \\
(7.79) \\
\end{array}$ \\
\hline $\begin{array}{l}\text { Black } \\
\text { (SD) }\end{array}$ & $\begin{array}{c}9.10 \\
(14.35) \\
\end{array}$ & $\begin{array}{c}0.71 \\
(1.59) \\
\end{array}$ & $\begin{array}{c}2.02 \\
(2.59) \\
\end{array}$ & $\begin{array}{c}2.25 \\
(4.13) \\
\end{array}$ & $\begin{array}{c}4.14 \\
(4.78) \\
\end{array}$ & $\begin{array}{c}2.40 \\
(3.97) \\
\end{array}$ & $\begin{array}{c}5.72 \\
(8.31) \\
\end{array}$ & $\begin{array}{c}18.36 \\
(18.22) \\
\end{array}$ & $\begin{array}{l}12.75 \\
(7.06) \\
\end{array}$ \\
\hline \multicolumn{10}{|l|}{$\%$ Health Indicator } \\
\hline $\begin{array}{l}\text { Obesity } \\
\text { (SD) }\end{array}$ & $\begin{array}{l}28.77 \\
(3.13) \\
\end{array}$ & $\begin{array}{l}26.02 \\
(3.46) \\
\end{array}$ & $\begin{array}{l}25.79 \\
(3.18) \\
\end{array}$ & $\begin{array}{l}28.67 \\
(2.17) \\
\end{array}$ & $\begin{array}{l}26.71 \\
(3.41) \\
\end{array}$ & $\begin{array}{l}23.77 \\
(2.43) \\
\end{array}$ & $\begin{array}{l}27.82 \\
(2.68) \\
\end{array}$ & $\begin{array}{l}30.37 \\
(2.76) \\
\end{array}$ & $\begin{array}{l}25.43 \\
(2.50) \\
\end{array}$ \\
\hline $\begin{array}{l}\text { Physical Activity } \\
\text { (SD) }\end{array}$ & $\begin{array}{l}52.92 \\
(7.01) \\
\end{array}$ & $\begin{array}{l}60.49 \\
(5.20) \\
\end{array}$ & $\begin{array}{l}63.90 \\
(5.07) \\
\end{array}$ & $\begin{array}{l}53.50 \\
(4.79) \\
\end{array}$ & $\begin{array}{l}54.55 \\
(6.99) \\
\end{array}$ & $\begin{array}{l}62.44 \\
(4.33) \\
\end{array}$ & $\begin{array}{l}56.25 \\
(4.19) \\
\end{array}$ & $\begin{array}{l}48.62 \\
(6.55) \\
\end{array}$ & $\begin{array}{l}55.87 \\
(5.85) \\
\end{array}$ \\
\hline $\begin{array}{l}\text { Smoking } \\
\text { (SD) }\end{array}$ & $\begin{array}{l}23.29 \\
(3.87) \\
\end{array}$ & $\begin{array}{l}19.40 \\
(3.28) \\
\end{array}$ & $\begin{array}{l}19.63 \\
(2.70) \\
\end{array}$ & $\begin{array}{l}22.11 \\
(2.55)\end{array}$ & $\begin{array}{l}18.78 \\
(2.37) \\
\end{array}$ & $\begin{array}{l}20.71 \\
(3.08) \\
\end{array}$ & $\begin{array}{l}23.41 \\
(3.57) \\
\end{array}$ & $\begin{array}{l}25.72 \\
(3.41) \\
\end{array}$ & $\begin{array}{l}21.26 \\
(2.50) \\
\end{array}$ \\
\hline \multicolumn{10}{|l|}{ Labor Force } \\
\hline $\begin{array}{l}\text { Unemployment rate } \\
\text { (SD) }\end{array}$ & $\begin{array}{c}57.43 \\
(29.75) \\
\end{array}$ & $\begin{array}{c}71.01 \\
(38.00) \\
\end{array}$ & $\begin{array}{c}75.54 \\
(27.74) \\
\end{array}$ & $\begin{array}{c}48.30 \\
(28.63) \\
\end{array}$ & $\begin{array}{c}75.25 \\
(35.53) \\
\end{array}$ & $\begin{array}{c}50.72 \\
(15.36) \\
\end{array}$ & $\begin{array}{c}58.83 \\
(25.12) \\
\end{array}$ & $\begin{array}{c}58.89 \\
(27.72) \\
\end{array}$ & $\begin{array}{c}49.66 \\
(15.99) \\
\end{array}$ \\
\hline
\end{tabular}

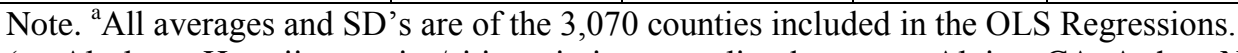

(no Alaska or Hawaii; counties/cities missing mortality data were: Alpine, CA, Arthur, NE, Banner, NE, Billings, ND, Blaine, NE, Borden, TX, Camas, ID,

Clark, ID, Daggett, UT, Glasscock, TX, Grant, NE, Harding, NM, Hayes, NE, Hinsdale, CO, Jones, SD, Kenedy, TX, Keya Paha, NE, King, TX, Logan, NE, Loupe, NE, Loving, TX, McMullen, TX, McPherson, NE, Mineral, CO, Petroleum, MT, Roberts, TX, San Juan, CO, Sioux, NE, Slope, ND, Sully, SD, Thomas, NE, Treasure, MT, Wheeler, NE; counties missing data on mediators: Bedford City, VA, Broomfield, CO, Clifton Forge City, VA, Fairfax City, VA, Franklin City, VA, Manassas Park City, VA, Waynesboro City, VA) 
Table 5c. Descriptives of Garreau's Nine Nations - Female

\begin{tabular}{|c|c|c|c|c|c|c|c|c|c|}
\hline Variable & USA & $\begin{array}{l}\text { The Empty } \\
\text { Quarter } \\
\text { (1) }\end{array}$ & $\begin{array}{l}\text { Ecotopia } \\
\text { (2) }\end{array}$ & $\begin{array}{c}\text { The } \\
\text { Breadbasket } \\
\text { (3) }\end{array}$ & $\begin{array}{c}\text { MexAmerica } \\
\text { (4) }\end{array}$ & $\begin{array}{c}\text { New } \\
\text { England } \\
\text { (5) }\end{array}$ & $\begin{array}{c}\text { The } \\
\text { Foundry } \\
(6)\end{array}$ & $\begin{array}{l}\text { Dixie } \\
\text { (7) }\end{array}$ & $\begin{array}{c}\text { The Islands } \\
\text { (8) }\end{array}$ \\
\hline \# of counties & 3,109 & 236 & 61 & 953 & 141 & 66 & 426 & 1,219 & 7 \\
\hline $\begin{array}{l}\text { \# of counties included in } \\
\text { OLS Regressions }{ }^{\mathrm{a}}\end{array}$ & 3,070 & 229 & 61 & 931 & 136 & 66 & 424 & 1,216 & 7 \\
\hline $\begin{array}{l}\text { Avg. Female Mortality rate } \\
\text { (SD) }\end{array}$ & $\begin{array}{c}701.45 \\
(119.71) \\
\end{array}$ & $\begin{array}{c}637.85 \\
(103.69) \\
\end{array}$ & $\begin{array}{l}623.50 \\
(82.34) \\
\end{array}$ & $\begin{array}{c}658.88 \\
(115.88) \\
\end{array}$ & $\begin{array}{l}616.31 \\
(95.00) \\
\end{array}$ & $\begin{array}{l}607.19 \\
(49.71) \\
\end{array}$ & $\begin{array}{l}971.82 \\
(76.62) \\
\end{array}$ & $\begin{array}{c}775.91 \\
(102.86) \\
\end{array}$ & $\begin{array}{l}525.99 \\
(72.13) \\
\end{array}$ \\
\hline $\begin{array}{l}\text { Avg. \# Female } \\
\text { (SD) (in 2000) }\end{array}$ & $\begin{array}{c}46,508.37 \\
(150,864.3) \\
\end{array}$ & $\begin{array}{c}26,124.28 \\
(65,380.89) \\
\end{array}$ & $\begin{array}{c}101,651 \\
(140,159.8) \\
\end{array}$ & $\begin{array}{c}20,602.58 \\
(52,765.26) \\
\end{array}$ & $\begin{array}{c}166,340.2 \\
(502,878.4) \\
\end{array}$ & $\begin{array}{c}102,148.4 \\
(141,941.5) \\
\end{array}$ & $\begin{array}{c}100,246 \\
(208,554.8) \\
\end{array}$ & $\begin{array}{c}30,050.86 \\
(60,293.97) \\
\end{array}$ & $\begin{array}{r}429,470.7 \\
(447,252.3) \\
\end{array}$ \\
\hline \multicolumn{10}{|c|}{ FEMALE } \\
\hline \multicolumn{10}{|l|}{ \% Education } \\
\hline $\begin{array}{l}\mathrm{HS} \\
(\mathrm{SD}) \\
\end{array}$ & $\begin{array}{l}21.78 \\
(8.41)\end{array}$ & $\begin{array}{l}15.40 \\
(5.78)\end{array}$ & $\begin{array}{l}16.08 \\
(5.52)\end{array}$ & $\begin{array}{l}18.08 \\
(6.42) \\
\end{array}$ & $\begin{array}{c}27.30 \\
(11.93)\end{array}$ & $\begin{array}{l}14.17 \\
(4.46)\end{array}$ & $\begin{array}{l}17.73 \\
(4.74)\end{array}$ & $\begin{array}{l}27.31 \\
(7.17)\end{array}$ & $\begin{array}{l}21.63 \\
(9.45)\end{array}$ \\
\hline $\begin{array}{l}\text { HS/Some College } \\
\text { (SD) }\end{array}$ & $\begin{array}{l}62.20 \\
(6.87) \\
\end{array}$ & $\begin{array}{l}65.71 \\
(6.43) \\
\end{array}$ & $\begin{array}{l}62.73 \\
(7.61) \\
\end{array}$ & $\begin{array}{l}65.64 \\
(5.68) \\
\end{array}$ & $\begin{array}{l}54.95 \\
(8.47) \\
\end{array}$ & $\begin{array}{l}59.87 \\
(5.46) \\
\end{array}$ & $\begin{array}{l}64.64 \\
(7.11) \\
\end{array}$ & $\begin{array}{l}58.98 \\
(5.13) \\
\end{array}$ & $\begin{array}{l}58.16 \\
(5.77) \\
\end{array}$ \\
\hline $\begin{array}{l}\text { 4yr College+ } \\
\text { (SD) }\end{array}$ & $\begin{array}{l}16.02 \\
(7.13) \\
\end{array}$ & $\begin{array}{l}18.89 \\
(8.57) \\
\end{array}$ & $\begin{array}{l}21.19 \\
(9.15) \\
\end{array}$ & $\begin{array}{l}16.27 \\
(5.27) \\
\end{array}$ & $\begin{array}{l}17.75 \\
(8.63) \\
\end{array}$ & $\begin{array}{l}25.96 \\
(7.39) \\
\end{array}$ & $\begin{array}{l}17.63 \\
(8.66) \\
\end{array}$ & $\begin{array}{l}13.71 \\
(6.05) \\
\end{array}$ & $\begin{array}{l}20.21 \\
(5.62) \\
\end{array}$ \\
\hline \multicolumn{10}{|l|}{$\%$ Race } \\
\hline $\begin{array}{l}\text { White } \\
\text { (SD) }\end{array}$ & $\begin{array}{c}87.71 \\
(15.97) \\
\end{array}$ & $\begin{array}{c}92.74 \\
(12.00) \\
\end{array}$ & $\begin{array}{l}89.89 \\
(7.62) \\
\end{array}$ & $\begin{array}{c}94.32 \\
(10.33) \\
\end{array}$ & $\begin{array}{l}91.16 \\
(8.51) \\
\end{array}$ & $\begin{array}{l}95.07 \\
(5.30) \\
\end{array}$ & $\begin{array}{c}92.27 \\
(10.29) \\
\end{array}$ & $\begin{array}{c}79.25 \\
(19.08) \\
\end{array}$ & $\begin{array}{l}84.49 \\
(8.00) \\
\end{array}$ \\
\hline $\begin{array}{l}\text { Black } \\
\text { (SD) }\end{array}$ & $\begin{array}{c}8.93 \\
(15.05)\end{array}$ & $\begin{array}{c}0.43 \\
(1.10)\end{array}$ & $\begin{array}{c}1.52 \\
(2.41)\end{array}$ & $\begin{array}{c}1.68 \\
(3.82) \\
\end{array}$ & $\begin{array}{c}3.49 \\
(4.96)\end{array}$ & $\begin{array}{c}2.21 \\
(4.16)\end{array}$ & $\begin{array}{c}5.15 \\
(8.91) \\
\end{array}$ & $\begin{array}{c}18.73 \\
(19.12)\end{array}$ & $\begin{array}{l}13.11 \\
(7.38) \\
\end{array}$ \\
\hline \multicolumn{10}{|l|}{$\begin{array}{l}\% \text { Health } \\
\text { Indicator }\end{array}$} \\
\hline $\begin{array}{l}\text { Obesity } \\
\text { (SD) }\end{array}$ & $\begin{array}{l}31.35 \\
(5.05) \\
\end{array}$ & $\begin{array}{l}27.24 \\
(4.11) \\
\end{array}$ & $\begin{array}{l}28.53 \\
(3.98) \\
\end{array}$ & $\begin{array}{l}29.91 \\
(3.19) \\
\end{array}$ & $\begin{array}{l}31.73 \\
(5.65) \\
\end{array}$ & $\begin{array}{l}25.15 \\
(3.08) \\
\end{array}$ & $\begin{array}{l}29.62 \\
(3.44) \\
\end{array}$ & $\begin{array}{l}34.29 \\
(5.22) \\
\end{array}$ & $\begin{array}{l}26.39 \\
(5.16) \\
\end{array}$ \\
\hline $\begin{array}{l}\text { Physical Activity } \\
\text { (SD) }\end{array}$ & $\begin{array}{l}43.86 \\
(7.98) \\
\end{array}$ & $\begin{array}{l}54.00 \\
(4.83) \\
\end{array}$ & $\begin{array}{l}56.73 \\
(4.95) \\
\end{array}$ & $\begin{array}{l}46.49 \\
(5.00) \\
\end{array}$ & $\begin{array}{l}46.14 \\
(7.34) \\
\end{array}$ & $\begin{array}{l}53.93 \\
(5.01) \\
\end{array}$ & $\begin{array}{l}46.58 \\
(4.50) \\
\end{array}$ & $\begin{array}{l}37.54 \\
(6.30) \\
\end{array}$ & $\begin{array}{l}43.77 \\
(6.61) \\
\end{array}$ \\
\hline $\begin{array}{l}\text { Smoking } \\
(\mathrm{SD})\end{array}$ & $\begin{array}{l}19.92 \\
(3.78) \\
\end{array}$ & $\begin{array}{l}17.58 \\
(3.89) \\
\end{array}$ & $\begin{array}{l}16.88 \\
(3.68) \\
\end{array}$ & $\begin{array}{l}19.06 \\
(2.72) \\
\end{array}$ & $\begin{array}{l}14.84 \\
(2.92 \\
\end{array}$ & $\begin{array}{l}18.40 \\
(2.68) \\
\end{array}$ & $\begin{array}{l}20.85 \\
(3.44) \\
\end{array}$ & $\begin{array}{l}21.50 \\
(3.68) \\
\end{array}$ & $\begin{array}{l}17.34 \\
(2.78) \\
\end{array}$ \\
\hline \multicolumn{10}{|l|}{ Labor Force } \\
\hline $\begin{array}{l}\text { Unemployment rate } \\
\text { (SD) }\end{array}$ & $\begin{array}{l}57.70 \\
(28.10) \\
\end{array}$ & $\begin{array}{c}61.11 \\
(27.37) \\
\end{array}$ & $\begin{array}{c}68.33 \\
(20.72) \\
\end{array}$ & $\begin{array}{c}43.52 \\
(24.29) \\
\end{array}$ & $\begin{array}{c}76.97 \\
(36.25) \\
\end{array}$ & $\begin{array}{c}44.62 \\
(11.41) \\
\end{array}$ & $\begin{array}{c}53.07 \\
(19.26)\end{array}$ & $\begin{array}{c}67.56 \\
(27.88) \\
\end{array}$ & $\begin{array}{c}57.86 \\
(29.45) \\
\end{array}$ \\
\hline
\end{tabular}

Note. 'All averages and SD's are of the 3,070 counties included in the OLS Regressions.

(no Alaska or Hawaii; counties/cities missing mortality data were: Alpine, CA, Arthur, NE, Banner, NE, Billings, ND, Blaine, NE, Borden, TX, Camas, ID,

Clark, ID, Daggett, UT, Glasscock, TX, Grant, NE, Harding, NM, Hayes, NE, Hinsdale, CO, Jones, SD, Kenedy, TX, Keya Paha, NE, King, TX, Logan, NE,

Loupe, NE, Loving, TX, McMullen, TX, McPherson, NE, Mineral, CO, Petroleum, MT, Roberts, TX, San Juan, CO, Sioux, NE, Slope, ND, Sully, SD, Thomas, NE, Treasure, MT, Wheeler, NE; counties missing data on mediators: Bedford City, VA, Broomfield, CO, Clifton Forge City, VA, Fairfax City, VA, Franklin City, VA, Manassas Park City, VA, Waynesboro City, VA) 
Table 6. Model 1a: Male Mortality without Mediators

\begin{tabular}{|c|c|c|c|c|c|c|c|c|}
\hline \multirow{2}{*}{ Mortality } & \multicolumn{2}{|c|}{ Census } & \multirow{2}{*}{ Mortality } & \multicolumn{2}{|c|}{ Woodard } & \multirow{2}{*}{ Mortality } & \multicolumn{2}{|c|}{ Garreau } \\
\hline & Coef & Beta & & Coef & Beta & & Coef & Beta \\
\hline Intercept & $\begin{array}{c}848.79 * * * \\
(9.20)\end{array}$ & -- & Intercept & $\begin{array}{c}866.39 * * * \\
(4.41)\end{array}$ & -- & Intercept & $\begin{array}{c}851.12 * * \\
* \\
(9.04)\end{array}$ & -- \\
\hline Region & & & Region & & & Region & & \\
\hline New England (ref) & 0 & 0 & Yankeedom (ref) & 0 & 0 & New England (ref) & 0 & 0 \\
\hline Mid Atlantic & $\begin{array}{l}45.60 * * * \\
(12.10)\end{array}$ & 0.058 & Deep South & $\begin{array}{c}238.38 \text { **** } \\
(8.50)\end{array}$ & 0.517 & The Empty Quarter & $\begin{array}{c}8.54 \\
(13.36) \\
\end{array}$ & 0.013 \\
\hline East North Central & $\begin{array}{l}97.92 \text { *** } \\
(10.59)\end{array}$ & 0.201 & El Norte & $\begin{array}{c}24.26 \\
(16.73)\end{array}$ & 0.023 & Ecotopia & $\begin{array}{c}-0.86 \\
(17.00)\end{array}$ & -0.001 \\
\hline West North Central & $\begin{array}{l}59.83 * * * \\
(11.02) \\
\end{array}$ & 0.139 & Far West & $\begin{array}{l}11.62 \\
(9.27) \\
\end{array}$ & 0.023 & Breadbasket & $\begin{array}{l}69.50 * * * \\
(10.16) \\
\end{array}$ & 0.188 \\
\hline South Atlantic & $\begin{array}{l}174.85^{* * * *} \\
(11.37)\end{array}$ & 0.403 & Greater Appalachia & $\begin{array}{c}194.99 * * * \\
(6.54)\end{array}$ & 0.524 & MexAmerica & $\begin{array}{c}14.41 \\
(15.50)\end{array}$ & 0.017 \\
\hline East South Central & $\begin{array}{l}317.43 * * * \\
(11.97)\end{array}$ & 0.602 & Left Coast & $\begin{array}{l}-40.49^{*} \\
(15.70)\end{array}$ & -0.031 & The Foundry & $\begin{array}{l}78.91 * * * \\
(10.57)\end{array}$ & 0.160 \\
\hline West South Central & $\begin{array}{l}194.80^{* * * *} \\
(11.61)\end{array}$ & 0.409 & Midlands & $\begin{array}{l}49.10 * * * \\
(6.96)\end{array}$ & 0.103 & Dixie & $\begin{array}{l}238.43^{* * * *} \\
(10.08)\end{array}$ & 0.684 \\
\hline Mountain & $\begin{array}{c}23.37 \\
(13.21) \\
\end{array}$ & 0.039 & New France & $\begin{array}{l}219.36^{* * * *} \\
(20.99)\end{array}$ & 0.116 & The Islands & $\begin{array}{l}-85.57^{*} \\
(35.31)\end{array}$ & -0.024 \\
\hline Pacific & $\begin{array}{l}-10.12 \\
(12.89)\end{array}$ & -0.012 & New Netherlands & $\begin{array}{l}89.04 * * * \\
(15.76) \\
\end{array}$ & -0.046 & & & \\
\hline & & & Spanish Caribbean & \begin{tabular}{l|}
-44.61 \\
$(34.82)$ \\
\end{tabular} & -0.016 & & & \\
\hline & & & Tidewater & $\begin{array}{l}111.88^{* * * *} \\
(13.47)\end{array}$ & 0.139 & & & \\
\hline $\mathbf{N}$ & \multicolumn{2}{|c|}{3,070} & $\mathbf{N}$ & \multicolumn{2}{|c|}{3,070} & $\mathbf{N}$ & \multicolumn{2}{|c|}{3,070} \\
\hline Adj. $R^{2}$ & \multicolumn{2}{|c|}{0.3033} & Adj. $R^{2}$ & \multicolumn{2}{|c|}{0.3256} & Adj. $R^{2}$ & \multicolumn{2}{|c|}{0.2954} \\
\hline AIC & \multicolumn{2}{|c|}{39160.44} & AIC & \multicolumn{2}{|c|}{39062.58} & AIC & \multicolumn{2}{|c|}{39193.99} \\
\hline BIC & \multicolumn{2}{|c|}{39214.7} & BIC & \multicolumn{2}{|c|}{39128.91} & BIC & \multicolumn{2}{|c|}{39242.23} \\
\hline
\end{tabular}

Note. Coefficients with robust standard error in parentheses. ${ }^{*} \mathrm{p}<0.05,{ }^{*} \mathrm{p}<0.01, * * * \mathrm{p}<0.001$

Dependent variable: Male mortality (rates) in 2010 (2008-2012) 
Table 7. Model 1b: Female Mortality without Mediators

\begin{tabular}{|c|c|c|c|c|c|c|c|c|}
\hline \multirow{2}{*}{ Mortality } & \multicolumn{2}{|c|}{ Census } & \multirow{2}{*}{ Mortality } & \multicolumn{2}{|c|}{ Woodard } & \multirow{2}{*}{ Mortality } & \multicolumn{2}{|c|}{ Garreau } \\
\hline & Coef & Beta & & Coef & Beta & & Coef & Beta \\
\hline Intercept & $\begin{array}{c}605.80^{* * * *} \\
(6.15)\end{array}$ & -- & Intercept & $\begin{array}{c}619.00^{* * * *} \\
(3.36)\end{array}$ & -- & Intercept & $\begin{array}{c}607.19 * * * \\
(6.08)\end{array}$ & -- \\
\hline Region & & & Region & & & Region & & \\
\hline New England (ref) & 0 & 0 & Yankeedom (ref) & 0 & 0 & New England (ref) & 0 & 0 \\
\hline Mid Atlantic & $\begin{array}{l}35.40 * * * * \\
(7.96)\end{array}$ & 0.064 & Deep South & $\begin{array}{c}163.73 * * * \\
(5.58)\end{array}$ & 0.506 & The Empty Quarter & $\begin{array}{c}30.66 * * * \\
(9.16)\end{array}$ & 0.067 \\
\hline East North Central & $\begin{array}{l}\text { 75.18*** } \\
(7.22)\end{array}$ & 0.219 & El Norte & $\begin{array}{c}0.58 \\
(11.29)\end{array}$ & 0.001 & Ecotopia & $\begin{array}{c}16.30 \\
(12.11)\end{array}$ & 0.019 \\
\hline West North Central & $\begin{array}{l}\text { 34.04*** } \\
(7.82)\end{array}$ & 0.113 & Far West & $\begin{array}{l}21.07 * * \\
(6.89)\end{array}$ & 0.059 & Breadbasket & $\begin{array}{c}51.69 * * * \\
(7.17)\end{array}$ & 0.198 \\
\hline South Atlantic & $\begin{array}{c}126.94 * * * \\
(7.56)\end{array}$ & 0.416 & Greater Appalachia & $\begin{array}{c}146.89 * * * \\
(4.77)\end{array}$ & 0.562 & MexAmerica & $\begin{array}{c}9.12 \\
(10.15)\end{array}$ & 0.016 \\
\hline East South Central & $\begin{array}{c}218.15^{* * * *} \\
(7.95)\end{array}$ & 0.589 & Left Coast & $\begin{array}{l}-15.53 \\
(11.69)\end{array}$ & -0.017 & The Foundry & $\begin{array}{l}64.63 * * * \\
(7.13)\end{array}$ & 0.186 \\
\hline West South Central & $\begin{array}{c}151.54 * * * \\
(7.92)\end{array}$ & 0.453 & Midlands & $\begin{array}{l}34.56 * * * \\
(5.50)\end{array}$ & 0.103 & Dixie & $\begin{array}{c}168.72 * * * \\
(6.76)\end{array}$ & 0.689 \\
\hline Mountain & $\begin{array}{l}37.05 * * * \\
(8.84)\end{array}$ & 0.088 & New France & $\begin{array}{l}157.97 * * * \\
(17.64)\end{array}$ & 0.119 & The Islands & $\begin{array}{l}-81.21 * * \\
(26.00)\end{array}$ & -0.032 \\
\hline Pacific & $\begin{array}{c}9.32 \\
(9.31)\end{array}$ & 0.016 & New Netherlands & $\begin{array}{c}-64.24 * * * \\
(9.95) \\
\end{array}$ & -0.047 & & & \\
\hline & & & Spanish Caribbean & $\begin{array}{l}-30.12 \\
(35.14)\end{array}$ & -0.016 & & & \\
\hline & & & Tidewater & $\begin{array}{l}\text { 73.77*** } \\
(7.98)\end{array}$ & 0.130 & & & \\
\hline $\mathbf{N}$ & \multicolumn{2}{|c|}{3,070} & $\mathbf{N}$ & \multicolumn{2}{|c|}{3,070} & $\mathbf{N}$ & \multicolumn{2}{|c|}{3,070} \\
\hline Adj. $\mathbf{R}^{2}$ & \multicolumn{2}{|c|}{0.2942} & Adj. $\mathbf{R}^{2}$ & \multicolumn{2}{|c|}{0.3300} & Adj. $\mathbf{R}^{2}$ & \multicolumn{2}{|c|}{0.2686} \\
\hline AIC & \multicolumn{2}{|c|}{37031.92} & AIC & \multicolumn{2}{|c|}{36874.12} & AIC & \multicolumn{2}{|c|}{37140.42} \\
\hline BIC & \multicolumn{2}{|c|}{37086.18} & BIC & \multicolumn{2}{|c|}{36940.44} & BIC & \multicolumn{2}{|c|}{37188.65} \\
\hline
\end{tabular}

Note. Coefficients with robust standard error in parentheses. ${ }^{*} \mathrm{p}<0.05, * * \mathrm{p}<0.01, * * * \mathrm{p}<0.001$

Dependent variable: Female mortality (rates) in 2010 (2008-2012) 
Table 8. Model 2a: Male Mortality with "Place" Mediators

\begin{tabular}{|c|c|c|c|c|c|c|c|c|c|c|c|}
\hline \multirow{2}{*}{ Mortality } & \multicolumn{2}{|c|}{ Census } & \multirow{2}{*}{ Mortality } & \multicolumn{2}{|c|}{ Woodard } & \multirow{2}{*}{ Mortality } & \multicolumn{2}{|c|}{ Garreau } & \multirow{2}{*}{ Mortality } & \multicolumn{2}{|c|}{ No Regions } \\
\hline & Coef & Beta & & Coef & Beta & & Coef & Beta & & Coef & Beta \\
\hline Intercept & $\begin{array}{l}370.02 * * * * \\
(38.06)\end{array}$ & -- & Intercept & $\begin{array}{l}388.04 * * * * \\
(36.60)\end{array}$ & -- & Intercept & $\begin{array}{l}328.09 * * * \\
(35.54)\end{array}$ & -- & Intercept & $\begin{array}{l}125.05 * * \\
* \\
(32.72)\end{array}$ & -- \\
\hline Region & & & Region & & & Region & & & Region & & \\
\hline New England (ref) & 0 & 0 & Yankeedom (ref) & 0 & 0 & New England (ref) & 0 & 0 & -- & -- & -- \\
\hline Mid Atlantic & $\begin{array}{c}25.20^{*} \\
(12.29)\end{array}$ & 0.032 & Deep South & $\begin{array}{c}159.26 * * * \\
(9.37)\end{array}$ & 0.345 & The Empty Quarter & $\begin{array}{l}-38.43 * * \\
(13.59)\end{array}$ & -0.059 & & & \\
\hline East North Central & $\begin{array}{l}58.15^{* * * *} \\
(10.94)\end{array}$ & 0.119 & El Norte & $\begin{array}{l}-43.34 * * \\
(16.29) \\
\end{array}$ & -0.042 & Ecotopia & $\begin{array}{l}-42.23 * \\
(16.70) \\
\end{array}$ & -0.035 & & & \\
\hline West North Central & $\begin{array}{c}16.15 \\
(11.93) \\
\end{array}$ & 0.038 & Far West & $\begin{array}{l}-3.28 \\
(9.28) \\
\end{array}$ & -0.007 & Breadbasket & $\begin{array}{c}14.51 \\
(10.90) \\
\end{array}$ & 0.039 & & & \\
\hline South Atlantic & $\begin{array}{l}106.07 \text { **** } \\
(11.54)\end{array}$ & 0.244 & Greater Appalachia & $\begin{array}{c}140.52 * * * \\
(6.78)\end{array}$ & 0.377 & MexAmerica & $\begin{array}{l}-70.48^{* * * *} \\
(15.26)\end{array}$ & -0.085 & & & \\
\hline East South Central & $\begin{array}{l}205.48 * * * \\
(12.66)\end{array}$ & 0.390 & Left Coast & $\begin{array}{l}-43.72 * * \\
(15.19)\end{array}$ & -0.034 & The Foundry & $\begin{array}{l}47.41 \text { *** } \\
(10.64)\end{array}$ & 0.096 & & & \\
\hline West South Central & $\begin{array}{l}89.17 * * * \\
(12.88)\end{array}$ & 0.187 & Midlands & $\begin{array}{l}46.80^{* * * *} \\
(7.05)\end{array}$ & 0.098 & Dixie & $\begin{array}{l}138.93 * * * * \\
(10.77)\end{array}$ & 0.399 & & & \\
\hline Mountain & $\begin{array}{l}-24.41 \\
(13.63)\end{array}$ & -0.041 & New France & $\begin{array}{l}138.28 * * * \\
(21.22)\end{array}$ & 0.073 & The Islands & $\begin{array}{l}- \\
127.98 * * * \\
(36.48)\end{array}$ & -0.036 & & & \\
\hline Pacific & $\begin{array}{l}-53.53^{\text {**** }} \\
(13.09)\end{array}$ & -0.064 & New Netherlands & $\begin{array}{l}-49.78 * * \\
(18.79)\end{array}$ & -0.026 & & & & & & \\
\hline & & & Spanish Caribbean & $\begin{array}{l}-56.25 \\
(36.85) \\
\end{array}$ & -0.021 & & & & & & \\
\hline & & & Tidewater & $\begin{array}{l}95.62 * * * \\
(11.91)\end{array}$ & 0.119 & & & & & & \\
\hline RUC Code $^{\mathrm{a}}$ & & & RUC Code $^{\mathrm{a}}$ & & & RUC Code $^{\mathrm{a}}$ & & & RUC Code $^{\mathrm{a}}$ & & \\
\hline 1 (ref) & 0 & 0 & 1 (ref) & 0 & 0 & 1 (ref) & 0 & 0 & 1 (ref) & 0 & 0 \\
\hline 2 & $\begin{array}{c}8.72 \\
(8.80)\end{array}$ & 0.016 & 2 & $\begin{array}{c}3.22 \\
(8.71)\end{array}$ & 0.006 & 2 & $\begin{array}{l}-3.48 \\
(8.52)\end{array}$ & -0.006 & 2 & $\begin{array}{l}-7.40 \\
(9.89)\end{array}$ & -0.013 \\
\hline 3 & $\begin{array}{l}13.09 \\
(8.96) \\
\end{array}$ & 0.024 & 3 & $\begin{array}{c}2.94 \\
(8.98) \\
\end{array}$ & 0.005 & 3 & $\begin{array}{l}10.41 \\
(8.90)\end{array}$ & 0.019 & 3 & $\begin{array}{c}-4.89 \\
(10.06) \\
\end{array}$ & -0.009 \\
\hline 4 & $\begin{array}{l}34.51 * * * \\
(9.73) \\
\end{array}$ & 0.052 & 4 & $\begin{array}{l}30.55^{* *} \\
(9.66) \\
\end{array}$ & 0.046 & 4 & $\begin{array}{l}28.30^{* * *} \\
(9.42) \\
\end{array}$ & 0.043 & 4 & $\begin{array}{c}2.61 \\
(10.66) \\
\end{array}$ & 0.004 \\
\hline 5 & $\begin{array}{l}\text { 49.24** } \\
(14.71)\end{array}$ & 0.052 & 5 & $\begin{array}{c}37.69^{*} \\
(14.71)\end{array}$ & 0.039 & 5 & $\begin{array}{c}42.51 * * \\
(14.54)\end{array}$ & 0.045 & 5 & $\begin{array}{c}10.70 \\
(16.08)\end{array}$ & 0.011 \\
\hline
\end{tabular}




\begin{tabular}{|c|c|c|c|c|c|c|c|c|c|c|c|}
\hline 6 & $\begin{array}{l}41.29 * * * \\
(8.96)\end{array}$ & 0.097 & 6 & $\begin{array}{l}29.88^{* *} \\
(8.86)\end{array}$ & 0.070 & 6 & $\begin{array}{l}34.87 * * * \\
(8.87)\end{array}$ & 0.082 & 6 & $\begin{array}{l}15.29 \\
(9.95)\end{array}$ & 0.036 \\
\hline 7 & $\begin{array}{l}28.74 * * \\
(10.05) \\
\end{array}$ & 0.059 & 7 & $\begin{array}{l}27.19 * * \\
(9.79) \\
\end{array}$ & 0.056 & 7 & $\begin{array}{l}21.88^{*} \\
(9.65) \\
\end{array}$ & 0.045 & 7 & $\begin{array}{c}-9.12 \\
(11.00) \\
\end{array}$ & -0.019 \\
\hline 8 & $\begin{array}{c}7.67 \\
(12.87)\end{array}$ & 0.012 & 8 & $\begin{array}{c}9.43 \\
(12.83)\end{array}$ & 0.014 & 8 & $\begin{array}{c}2.87 \\
(12.77)\end{array}$ & 0.004 & 8 & $\begin{array}{l}-11.42 \\
(14.13)\end{array}$ & -0.018 \\
\hline 9 & $\begin{array}{c}11.83 \\
(12.28) \\
\end{array}$ & 0.023 & 9 & $\begin{array}{c}17.85 \\
(12.03) \\
\end{array}$ & 0.035 & 9 & $\begin{array}{c}2.42 \\
(12.01) \\
\end{array}$ & 0.005 & 9 & $\begin{array}{l}-24.28 \\
(13.34) \\
\end{array}$ & -0.048 \\
\hline Typology $^{b}$ & & & Typology $^{b}$ & & & Typology $^{b}$ & & & Typology $^{b}$ & & \\
\hline $\begin{array}{l}\text { Non-dependent } \\
\text { (ref) }\end{array}$ & 0 & 0 & $\begin{array}{l}\text { Non-dependent } \\
\text { (ref) }\end{array}$ & 0 & 0 & $\begin{array}{l}\text { Non-dependent } \\
\text { (ref) }\end{array}$ & 0 & 0 & $\begin{array}{l}\text { Non-dependent } \\
\text { (ref) }\end{array}$ & 0 & 0 \\
\hline Farming & $\begin{array}{c}-49.33 * * * \\
(9.34)\end{array}$ & -0.099 & Farming & $\begin{array}{c}-50.07 * * * \\
(9.30)\end{array}$ & -0.100 & Farming & $\begin{array}{l}-45.13 * * * \\
(9.23)\end{array}$ & -0.090 & Farming & $\begin{array}{l}-69.03 * * * \\
(10.10)\end{array}$ & -0.138 \\
\hline Mining & $\begin{array}{l}\text { 63.15*** } \\
(14.05)\end{array}$ & 0.073 & Mining & $\begin{array}{l}58.58 * * * \\
(14.53)\end{array}$ & 0.068 & Mining & $\begin{array}{l}\text { 70.01*** } \\
(13.41)\end{array}$ & 0.081 & Mining & $\begin{array}{l}\text { 63.49*** } \\
(15.00)\end{array}$ & 0.074 \\
\hline Manufacturing & $\begin{array}{c}8.16 \\
(5.69) \\
\end{array}$ & 0.022 & Manufacturing & $\begin{array}{l}20.91 * * * \\
(5.40) \\
\end{array}$ & 0.056 & Manufacturing & $\begin{array}{c}7.23 \\
(5.61) \\
\end{array}$ & 0.019 & Manufacturing & $\begin{array}{l}40.80^{* * * *} \\
(5.96)\end{array}$ & 0.109 \\
\hline Government & $\begin{array}{c}-27.33 * * \\
(9.25) \\
\end{array}$ & -0.052 & Government & \begin{tabular}{|c|}
$-18.83 *$ \\
$(8.93)$ \\
\end{tabular} & -0.036 & Government & $\begin{array}{c}-24.95^{* *} \\
(9.12) \\
\end{array}$ & -0.048 & Government & $\begin{array}{c}-27.60 * * \\
(9.84) \\
\end{array}$ & -0.053 \\
\hline Service & $\begin{array}{l}-79.27 * * * \\
(9.44)\end{array}$ & -0.144 & Service & $\begin{array}{c}-72.55 * * * \\
(9.42)\end{array}$ & -0.132 & Service & $\begin{array}{l}-81.69 * * * \\
(9.33)\end{array}$ & -0.149 & Service & $\begin{array}{l}-98.46 * * * \\
(10.57)\end{array}$ & -0.179 \\
\hline Medical Care & & & Medical Care & & & Medical Care & & & Medical Care & & \\
\hline Active MDs (rate) & $\begin{array}{l}-20.72 * * * \\
(3.00)\end{array}$ & -0.163 & Active MDs (rate) & $\begin{array}{l}-17.47 * * * \\
(2.73)\end{array}$ & $-\overline{0.137}$ & Active MDs (rate) & $\begin{array}{l}-22.37 * * * \\
(3.09)\end{array}$ & -0.176 & Active MDs (rate) & $\begin{array}{c}-26.90 * * * \\
(3.73)\end{array}$ & -0.211 \\
\hline Hospital Beds (rate) & $\begin{array}{c}2.29 * * \\
(0.695) \\
\end{array}$ & 0.069 & Hospital Beds (rate) & $\begin{array}{l}2.27 * * \\
(0.66) \\
\end{array}$ & 0.069 & Hospital Beds (rate) & $\begin{array}{l}2.16^{* *} \\
(0.67) \\
\end{array}$ & 0.065 & Hospital Beds (rate) & $\begin{array}{l}2.14 * * \\
(0.69) \\
\end{array}$ & 0.065 \\
\hline Inequality & & & Inequality & & & Inequality & & & Inequality & & \\
\hline Gini $^{c}$ & $\begin{array}{l}12.68 * * * \\
(0.93)\end{array}$ & 0.287 & Gini $^{\mathrm{c}}$ & $\begin{array}{l}13.04 * * * \\
(0.94)\end{array}$ & 0.294 & Gini $^{c}$ & $\begin{array}{l}14.00^{* * * *} \\
(0.86)\end{array}$ & 0.317 & Gini $^{\mathrm{c}}$ & $\begin{array}{l}20.46^{* * * *} \\
(0.81)\end{array}$ & 0.463 \\
\hline $\mathbf{N}$ & \multicolumn{2}{|c|}{3,070} & $\mathbf{N}$ & \multicolumn{2}{|c|}{3,070} & $\mathbf{N}$ & \multicolumn{2}{|c|}{3,070} & $\mathbf{N}$ & \multicolumn{2}{|c|}{3,070} \\
\hline Adj. $\mathbf{R}^{2}$ & \multicolumn{2}{|c|}{0.4305} & Adj. $\mathbf{R}^{2}$ & \multicolumn{2}{|c|}{0.4438} & Adj. $\mathbf{R}^{2}$ & \multicolumn{2}{|c|}{0.4474} & Adj. $\mathbf{R}^{2}$ & \multicolumn{2}{|c|}{0.3100} \\
\hline AIC & \multicolumn{2}{|c|}{38557.48} & AIC & \multicolumn{2}{|c|}{38486.68} & AIC & \multicolumn{2}{|c|}{38464.27} & AIC & \multicolumn{2}{|c|}{39138.55} \\
\hline BIC & \multicolumn{2}{|c|}{38708.22} & BIC & \multicolumn{2}{|c|}{38649.48} & BIC & \multicolumn{2}{|c|}{38608.98} & BIC & \multicolumn{2}{|c|}{39241.05} \\
\hline
\end{tabular}

Note. Coefficients with robust standard error in parentheses. ${ }^{*} \mathrm{p}<0.05, * * \mathrm{p}<0.01, * * * \mathrm{p}<0.001$

Dependent variable: Male mortality (rates) in 2010 (2008-2012)

${ }^{\mathrm{a}}=$ Rural Urban Continuum Code (2003)

${ }^{\mathrm{b}}=(2004) ;($ all other control variables are 2000 unless otherwise noted $)$

${ }^{\mathrm{c}}=$ Gini Index multiplied times 100 to see increment changes 
Table 9. Model 2b: Female Mortality with "Place" Mediators

\begin{tabular}{|c|c|c|c|c|c|c|c|c|c|c|c|}
\hline \multirow{2}{*}{ Mortality } & \multicolumn{2}{|c|}{ Census } & \multirow{2}{*}{ Mortality } & \multicolumn{2}{|c|}{ Woodard } & \multirow{2}{*}{ Mortality } & \multicolumn{2}{|c|}{ Garreau } & \multirow{2}{*}{ Mortality } & \multicolumn{2}{|c|}{ No Regions } \\
\hline & Coef & Beta & & Coef & Beta & & Coef & Beta & & Coef & Beta \\
\hline Intercept & $\begin{array}{l}348.73 * * * \\
(29.97)\end{array}$ & -- & Intercept & $\begin{array}{l}297.77 * * * \\
(28.14)\end{array}$ & -- & Intercept & $\begin{array}{l}276.60 * * * \\
(27.03)\end{array}$ & -- & Intercept & $\begin{array}{l}159.72 * * * \\
(23.68)\end{array}$ & -- \\
\hline Region & & & Region & & & Region & & & Region & & \\
\hline $\begin{array}{l}\text { New England } \\
\text { (ref) }\end{array}$ & 0 & 0 & Yankeedom (ref) & 0 & 0 & $\begin{array}{l}\text { New England } \\
\text { (ref) }\end{array}$ & 0 & 0 & -- & -- & -- \\
\hline Mid Atlantic & $\begin{array}{c}20.57 * \\
(8.07)\end{array}$ & 0.037 & Deep South & $\begin{array}{l}111.51^{* * * *} \\
(6.85)\end{array}$ & 0.344 & $\begin{array}{l}\text { The Empty } \\
\text { Quarter }\end{array}$ & $\begin{array}{l}-1.55 \\
(9.41)\end{array}$ & -0.003 & & & \\
\hline $\begin{array}{l}\text { East North } \\
\text { Central }\end{array}$ & $\begin{array}{l}45.05 * * * \\
(7.60)\end{array}$ & 0.132 & El Norte & $\begin{array}{l}-49.06^{* * * *} \\
(11.81)\end{array}$ & -0.067 & Ecotopia & $\begin{array}{l}-14.58 \\
(11.95)\end{array}$ & -0.017 & & & \\
\hline $\begin{array}{l}\text { West North } \\
\text { Central }\end{array}$ & $\begin{array}{c}5.71 \\
(8.57)\end{array}$ & 0.019 & Far West & $\begin{array}{l}12.92 \\
(9.79) \\
\end{array}$ & 0.036 & Breadbasket & $\begin{array}{l}17.06^{*} \\
(7.92) \\
\end{array}$ & 0.066 & & & \\
\hline South Atlantic & $\begin{array}{l}82.05^{* * * *} \\
(7.95)\end{array}$ & 0.269 & $\begin{array}{l}\text { Greater } \\
\text { Appalachia }\end{array}$ & $\begin{array}{l}109.64 * * * \\
(5.04)\end{array}$ & 0.419 & MexAmerica & $\begin{array}{l}-53.32 * * * \\
(10.89)\end{array}$ & -0.092 & & & \\
\hline $\begin{array}{l}\text { East South } \\
\text { Central }\end{array}$ & $\begin{array}{c}147.35^{* * * *} \\
(8.99) \\
\end{array}$ & 0.398 & Left Coast & $\begin{array}{l}-22.52^{*} \\
(11.16) \\
\end{array}$ & -0.025 & The Foundry & $\begin{array}{l}41.29 * * * \\
(7.51) \\
\end{array}$ & 0.119 & & & \\
\hline $\begin{array}{l}\text { West South } \\
\text { Central }\end{array}$ & $\begin{array}{l}83.53^{* * * *} \\
(9.07) \\
\end{array}$ & 0.250 & Midlands & $\begin{array}{l}34.71 * * * \\
(5.37) \\
\end{array}$ & 0.104 & Dixie & $\begin{array}{c}100.46^{* * * *} \\
(7.79) \\
\end{array}$ & 0.410 & & & \\
\hline Mountain & $\begin{array}{c}3.98 \\
(9.12)\end{array}$ & 0.009 & New France & $\begin{array}{l}97.89 * * * \\
(16.78)\end{array}$ & 0.073 & The Islands & $\begin{array}{l}-109.79 * * * \\
(26.49)\end{array}$ & -0.044 & & & \\
\hline Pacific & $\begin{aligned}-19.83^{*} \\
(9.40)\end{aligned}$ & -0.034 & New Netherlands & $\begin{array}{l}-41.88 * * \\
(12.92)\end{array}$ & -0.031 & & & & & & \\
\hline & & & $\begin{array}{l}\text { Spanish } \\
\text { Caribbean }\end{array}$ & $\begin{array}{l}-40.15 \\
(32.27)\end{array}$ & -0.021 & & & & & & \\
\hline & & & Tidewater & $\begin{array}{l}59.50 * * * \\
(7.50)\end{array}$ & 0.105 & & & & & & \\
\hline RUC Code $^{\mathrm{a}}$ & & & RUC Code $^{\mathrm{a}}$ & & & RUC Code $^{\mathrm{a}}$ & & & & & \\
\hline 1 (ref) & 0 & 0 & 1 (ref) & 0 & 0 & 1 (ref) & 0 & 0 & 1 (ref) & 0 & 0 \\
\hline 2 & $\begin{array}{c}1.91 \\
(6.10)\end{array}$ & 0.005 & 2 & $\begin{array}{l}-3.14 \\
(5.91)\end{array}$ & -0.008 & 2 & $\begin{array}{l}-7.52 \\
(5.98)\end{array}$ & -0.019 & 2 & $\begin{array}{l}-9.11 \\
(6.79)\end{array}$ & -0.023 \\
\hline 3 & $\begin{array}{c}4.01 \\
(6.30)\end{array}$ & 0.011 & 3 & $\begin{array}{l}-6.00 \\
(6.13)\end{array}$ & -0.016 & 3 & $\begin{array}{l}-0.89 \\
(6.34)\end{array}$ & -0.002 & 3 & $\begin{array}{l}-9.11 \\
(7.00)\end{array}$ & -0.024 \\
\hline 4 & $\begin{array}{l}14.37 * \\
(6.77) \\
\end{array}$ & 0.031 & 4 & $\begin{array}{l}11.04 \\
(6.53)\end{array}$ & 0.024 & 4 & $\begin{array}{c}8.05 \\
(6.57)\end{array}$ & 0.017 & 4 & $\begin{array}{l}-7.75 \\
(7.51)\end{array}$ & -0.017 \\
\hline 5 & $\begin{array}{l}\text { 27.72** } \\
(10.17)\end{array}$ & 0.041 & 5 & $\begin{array}{l}13.76 \\
(9.83)\end{array}$ & 0.021 & 5 & $\begin{array}{l}16.44 \\
(9.88)\end{array}$ & 0.025 & 5 & $\begin{array}{c}-2.02 \\
(10.80)\end{array}$ & -0.003 \\
\hline
\end{tabular}




\begin{tabular}{|c|c|c|c|c|c|c|c|c|c|c|c|}
\hline 6 & $\begin{array}{l}20.46^{* * *} \\
(6.33) \\
\end{array}$ & 0.068 & 6 & $\begin{array}{c}9.88 \\
(6.07) \\
\end{array}$ & 0.033 & 6 & $\begin{array}{l}13.14^{*} \\
(6.25) \\
\end{array}$ & 0.044 & 6 & $\begin{array}{c}1.84 \\
(6.98) \\
\end{array}$ & 0.006 \\
\hline 7 & $\begin{array}{l}14.55^{*} \\
(7.20)\end{array}$ & 0.043 & 7 & $\begin{array}{c}8.44 \\
(6.83)\end{array}$ & 0.025 & 7 & $\begin{array}{c}4.42 \\
(6.84)\end{array}$ & 0.013 & 7 & $\begin{array}{r}-13.85 \\
(7.63)\end{array}$ & -0.041 \\
\hline 8 & $\begin{array}{l}-6.95 \\
(9.42) \\
\end{array}$ & -0.015 & 8 & $\begin{array}{c}-12.07 \\
(9.29) \\
\end{array}$ & -0.026 & 8 & $\begin{array}{c}-16.61 \\
(9.44) \\
\end{array}$ & -0.036 & 8 & $\begin{array}{l}-23.74 * \\
(10.37) \\
\end{array}$ & -0.052 \\
\hline 9 & $\begin{array}{c}1.84 \\
(8.78)\end{array}$ & 0.005 & 9 & $\begin{array}{l}-2.86 \\
(8.40)\end{array}$ & -0.008 & 9 & $\begin{array}{r}-13.28 \\
(8.51)\end{array}$ & -0.037 & 9 & $\begin{array}{c}-29.00 * * \\
(9.45)\end{array}$ & -0.081 \\
\hline Typology & & & Typology $^{b}$ & & & Typology $^{b}$ & & & Typology $^{b}$ & & \\
\hline $\begin{array}{l}\text { Non-dependent } \\
\text { (ref) }\end{array}$ & 0 & 0 & $\begin{array}{l}\text { Non-dependent } \\
\text { (ref) }\end{array}$ & 0 & 0 & $\begin{array}{l}\text { Non-dependent } \\
\text { (ref) }\end{array}$ & 0 & 0 & $\begin{array}{l}\text { Non-dependent } \\
(\text { ref })\end{array}$ & & \\
\hline Farming & $\begin{array}{l}-40.79 * * * \\
(6.67)\end{array}$ & -0.116 & Farming & $\begin{array}{l}-40.93 * * * \\
(6.53)\end{array}$ & -0.117 & Farming & $\begin{array}{l}-37.84 * * * \\
(6.67)\end{array}$ & -0.108 & Farming & $\begin{array}{c}-53.35^{* * * *} \\
(7.19)\end{array}$ & -0.152 \\
\hline Mining & $\begin{array}{l}52.93^{* * * *} \\
(10.75)\end{array}$ & 0.087 & Mining & $\begin{array}{l}53.64 * * * \\
(10.48)\end{array}$ & 0.089 & Mining & $\begin{array}{l}62.24 * * * \\
(10.11)\end{array}$ & 0.103 & Mining & $\begin{array}{l}60.33^{* * *} \\
(11.04)\end{array}$ & 0.100 \\
\hline Manufacturing & $\begin{array}{c}3.37 \\
(4.09)\end{array}$ & 0.013 & Manufacturing & $\begin{array}{l}10.44 * * \\
(3.87)\end{array}$ & 0.040 & Manufacturing & $\begin{array}{c}1.96 \\
(4.09)\end{array}$ & 0.007 & Manufacturing & $\begin{array}{l}24.31 * * * \\
(4.31)\end{array}$ & 0.092 \\
\hline Government & $\begin{array}{r}-12.29 \\
(7.01) \\
\end{array}$ & -0.033 & Government & $\begin{array}{l}-2.63 \\
(6.50) \\
\end{array}$ & -0.007 & Government & $\begin{array}{l}-8.26 \\
(6.76) \\
\end{array}$ & -0.022 & Government & $\begin{array}{l}-9.69 \\
(7.25) \\
\end{array}$ & -0.026 \\
\hline Service & $\begin{array}{l}-55.56^{* * * *} \\
(6.48)\end{array}$ & -0.144 & Service & $\begin{array}{l}-51.40 * * * \\
(6.25)\end{array}$ & -0.133 & Service & $\begin{array}{l}-58.36^{* * * *} \\
(6.37)\end{array}$ & -0.151 & Service & $\begin{array}{l}-68.60 * * * \\
(7.19)\end{array}$ & -0.178 \\
\hline Medical Care & & & Medical Care & & & Medical Care & & & Medical Care & & \\
\hline $\begin{array}{l}\text { Active MDs } \\
\text { (rate) }\end{array}$ & $\begin{array}{l}-14.67 * * * \\
(2.18) \\
\end{array}$ & -0.164 & $\begin{array}{l}\text { Active MDs } \\
\text { (rate) }\end{array}$ & $\begin{array}{l}-12.56 \text { *** } \\
(2.02) \\
\end{array}$ & -0.140 & $\begin{array}{l}\text { Active MDs } \\
\text { (rate) }\end{array}$ & $\begin{array}{c}-16.65 * * * \\
(2.33) \\
\end{array}$ & -0.186 & $\begin{array}{l}\text { Active MDs } \\
\text { (rate) }\end{array}$ & $\begin{array}{c}-19.60 * * * \\
(2.76) \\
\end{array}$ & -0.219 \\
\hline $\begin{array}{l}\text { Hospital Beds } \\
\text { (rate) }\end{array}$ & $\begin{array}{c}1.17^{*} \\
(0.45) \\
\end{array}$ & 0.050 & $\begin{array}{l}\text { Hospital Beds } \\
\text { (rate) }\end{array}$ & $\begin{array}{c}0.93^{*} \\
(0.42) \\
\end{array}$ & 0.040 & $\begin{array}{l}\text { Hospital Beds } \\
\text { (rate) }\end{array}$ & $\begin{array}{c}0.85 \\
(0.45) \\
\end{array}$ & 0.037 & \begin{tabular}{|l|}
$\begin{array}{l}\text { Hospital Beds } \\
\text { (rate) }\end{array}$ \\
\end{tabular} & $\begin{array}{c}0.88 \\
(0.47) \\
\end{array}$ & 0.038 \\
\hline Inequality & & & Inequality & & & Inequality & & & Inequality & & \\
\hline $\operatorname{Gini}^{\mathrm{c}}$ & $\begin{array}{l}7.21 \text { *** } \\
(0.75)\end{array}$ & 0.232 & Gini $^{\mathrm{c}}$ & $\begin{array}{l}8.28 * * * \\
(0.73)\end{array}$ & 0.267 & Gini $^{\mathrm{c}}$ & $\begin{array}{l}9.27 * * * \\
(0.67)\end{array}$ & 0.298 & Gini $^{\mathrm{c}}$ & $\begin{array}{l}13.29 * * * \\
(0.59)\end{array}$ & 0.428 \\
\hline $\mathbf{N}$ & \multicolumn{2}{|c|}{3,070} & $\mathbf{N}$ & \multicolumn{2}{|c|}{3,070} & $\mathbf{N}$ & \multicolumn{2}{|c|}{3,070} & $\mathbf{N}$ & \multicolumn{2}{|c|}{3,070} \\
\hline Adj. $\mathbf{R}^{2}$ & \multicolumn{2}{|c|}{0.3996} & Adj. $\mathbf{R}^{2}$ & \multicolumn{2}{|c|}{0.4305} & Adj. $R^{2}$ & \multicolumn{2}{|c|}{0.4098} & Adj. $\mathbf{R}^{2}$ & \multicolumn{2}{|c|}{0.2832} \\
\hline AIC & \multicolumn{2}{|c|}{36551.61} & AIC & \multicolumn{2}{|c|}{36390.89} & AIC & \multicolumn{2}{|c|}{36497.99} & AIC & \multicolumn{2}{|c|}{37087.26} \\
\hline BIC & \multicolumn{2}{|c|}{36702.35} & BIC & \multicolumn{2}{|c|}{36553.68} & BIC & \multicolumn{2}{|c|}{36642.7} & BIC & \multicolumn{2}{|c|}{37189.76} \\
\hline
\end{tabular}

Note. Coefficients with robust standard error in parentheses. ${ }^{*} \mathrm{p}<0.05, * * \mathrm{p}<0.01, * * * \mathrm{p}<0.001$

Dependent variable: Male mortality (rates) in 2010 (2008-2012)

${ }^{\mathrm{b}}=(2004) ;($ all other control variables are 2000 unless otherwise noted $)$

${ }^{\mathrm{c}}=$ Gini Index multiplied times 100 to see increment changes 
Table 10. Model 3a: Male Mortality with "People" Mediators

\begin{tabular}{|c|c|c|c|c|c|c|c|c|c|c|c|}
\hline \multirow{2}{*}{ Mortality } & \multicolumn{2}{|c|}{ Census } & \multirow{2}{*}{ Mortality } & \multicolumn{2}{|c|}{ Woodard } & \multirow{2}{*}{ Mortality } & \multicolumn{2}{|c|}{ Garreau } & \multirow{2}{*}{ Mortality } & \multicolumn{2}{|c|}{\begin{tabular}{|l|} 
No Regions \\
\end{tabular}} \\
\hline & Coef & Beta & & Coef & Beta & & Coef & Beta & & Coef & Beta \\
\hline Intercept & $\begin{array}{l}425.54 * * * \\
(90.58)\end{array}$ & -- & Intercept & $\begin{array}{l}531.17 * * * \\
(91.85)\end{array}$ & -- & Intercept & $\begin{array}{l}450.43 * * * \\
(92.02)\end{array}$ & -- & Intercept & $\begin{array}{l}414.37 * * * \\
(93.87)\end{array}$ & -- \\
\hline Region & & & Region & & & Region & & & Region & & \\
\hline $\begin{array}{l}\text { New England } \\
\text { (ref) }\end{array}$ & 0 & 0 & Yankeedom (ref) & 0 & 0 & $\begin{array}{l}\text { New England } \\
\text { (ref) }\end{array}$ & 0 & 0 & -- & -- & -- \\
\hline Mid Atlantic & $\begin{array}{l}-40.18 * * * \\
(9.54)\end{array}$ & -0.051 & Deep South & $\begin{array}{l}74.03 * * * \\
(9.61) \\
\end{array}$ & 0.161 & $\begin{array}{l}\text { The Empty } \\
\text { Quarter }\end{array}$ & $\begin{array}{l}-66.92 * * * \\
(11.53)\end{array}$ & -0.103 & & & \\
\hline $\begin{array}{l}\text { East North } \\
\text { Central }\end{array}$ & $\begin{array}{l}-42.22 * * * \\
(9.07)\end{array}$ & -0.087 & El Norte & $\begin{array}{c}1.02 \\
(17.75)\end{array}$ & 0.001 & Ecotopia & $\begin{array}{l}-51.37 * * * \\
(11.71)\end{array}$ & -0.042 & & & \\
\hline $\begin{array}{l}\text { West North } \\
\text { Central }\end{array}$ & $\begin{array}{l}-55.67 * * * \\
(10.10)\end{array}$ & -0.130 & Far West & $\begin{array}{l}12.09 \\
(8.26)\end{array}$ & 0.024 & Breadbasket & $\begin{array}{c}-47.50 * * * \\
(9.21)\end{array}$ & -0.128 & & & \\
\hline South Atlantic & $\begin{array}{l}-6.16 \\
(9.92)\end{array}$ & -0.014 & $\begin{array}{l}\text { Greater } \\
\text { Appalachia }\end{array}$ & $\begin{array}{l}80.83 * * * * \\
(6.21)\end{array}$ & 0.217 & MexAmerica & $\begin{array}{l}-90.09 * * * \\
(13.77)\end{array}$ & -0.109 & & & \\
\hline $\begin{array}{l}\text { East South } \\
\text { Central }\end{array}$ & $\begin{array}{l}41.71^{* * *} \\
(12.57)\end{array}$ & 0.079 & Left Coast & $\begin{array}{l}12.08 \\
(9.67) \\
\end{array}$ & 0.009 & The Foundry & $\begin{array}{c}-37.35^{* * *} \\
(8.58) \\
\end{array}$ & -0.076 & & & \\
\hline $\begin{array}{l}\text { West South } \\
\text { Central }\end{array}$ & $\begin{array}{c}16.86 \\
(11.23)\end{array}$ & 0.035 & Midlands & $\begin{array}{l}16.93^{* *} \\
(6.08) \\
\end{array}$ & 0.036 & Dixie & $\begin{array}{c}4.84 \\
(9.60) \\
\end{array}$ & 0.014 & & & \\
\hline Mountain & $\begin{array}{l}-32.56 * * \\
(12.17) \\
\end{array}$ & -0.054 & New France & $\begin{array}{c}21.93 \\
(20.06) \\
\end{array}$ & 0.012 & The Islands & $\begin{array}{l}-179.62 * * * \\
(23.99) \\
\end{array}$ & -0.050 & & & \\
\hline \multirow[t]{3}{*}{ Pacific } & $\begin{array}{l}-66.46^{* * * *} \\
(11.02)\end{array}$ & -0.079 & New Netherlands & $\begin{array}{l}-33.95 \\
(17.95)\end{array}$ & -0.018 & & & & & & \\
\hline & & & $\begin{array}{l}\text { Spanish } \\
\text { Caribbean }\end{array}$ & $\begin{array}{l}-83.21 * * \\
(27.15) \\
\end{array}$ & -0.030 & & & & & & \\
\hline & & & Tidewater & $\begin{array}{c}21.80 * \\
(11.01) \\
\end{array}$ & 0.027 & & & & & & \\
\hline Medical Care & & & Medical Care & & & Medical Care & & & Medical Care & & \\
\hline $\begin{array}{l}\text { No Health Ins } \\
(\%)\end{array}$ & $\begin{array}{l}4.41 * * * \\
(0.86)\end{array}$ & 0.128 & $\begin{array}{l}\text { No Health Ins } \\
(\%)\end{array}$ & $\begin{array}{l}4.43 * * * \\
(0.79)\end{array}$ & 0.128 & $\begin{array}{l}\text { No Health Ins } \\
(\%)\end{array}$ & $\begin{array}{l}7.40 * * * \\
(0.73)\end{array}$ & 0.214 & $\begin{array}{l}\text { No Health Ins } \\
(\%)\end{array}$ & $\begin{array}{l}5.94 * * * \\
(0.67)\end{array}$ & 0.172 \\
\hline Education & & & Education & & & Education & & & Education & & \\
\hline$<\mathrm{HS}^{\mathrm{a}}(\mathrm{ref})$ & 0 & 0 & $<\mathrm{HS}^{\mathrm{a}}(\mathrm{ref})$ & 0 & 0 & $<\mathrm{HS}^{\mathrm{a}}(\mathrm{ref})$ & 0 & 0 & $<\mathrm{HS}^{\mathrm{a}}(\mathrm{ref})$ & 0 & 0 \\
\hline $\begin{array}{l}\text { HS/Some } \\
\text { College }\end{array}$ & $\begin{array}{l}3.34 * * * \\
(0.61)\end{array}$ & 0.145 & $\begin{array}{l}\text { HS/Some } \\
\text { College }\end{array}$ & $\begin{array}{l}2.30 * * * \\
(0.57)\end{array}$ & 0.010 & $\begin{array}{l}\text { HS/Some } \\
\text { College }\end{array}$ & $\begin{array}{l}2.95^{* * * *} \\
(0.58)\end{array}$ & 0.128 & $\begin{array}{l}\text { HS/Some } \\
\text { College }\end{array}$ & $\begin{array}{l}2.17 * * * \\
(0.55)\end{array}$ & 0.094 \\
\hline 4yr College + & $\begin{array}{l}1.75^{* * *} \\
(0.67)\end{array}$ & 0.089 & 4yr College + & $\begin{array}{l}1.28^{*} \\
(0.64)\end{array}$ & 0.065 & 4yr College + & $\begin{array}{l}2.13 * * \\
(0.64)\end{array}$ & 0.108 & 4yr College + & $\begin{array}{l}2.43 * * * \\
(0.63)\end{array}$ & 0.123 \\
\hline
\end{tabular}




\begin{tabular}{|c|c|c|c|c|c|c|c|c|c|c|c|}
\hline Race & & & Race & & & Race & & & Race & & \\
\hline Other (ref) & 0 & 0 & Other (ref) & 0 & 0 & Other (ref) & 0 & 0 & Other (ref) & 0 & 0 \\
\hline White & $\begin{array}{l}-1.93^{* * * *} \\
(0.43)\end{array}$ & -0.173 & White & $\begin{array}{l}-1.97 * * * \\
(0.43)\end{array}$ & -0.177 & White & $\begin{array}{l}-1.54 * * * \\
(0.43) \\
\end{array}$ & -0.138 & White & $\begin{array}{l}-1.52 * * * \\
(0.43)\end{array}$ & -0.136 \\
\hline Black & $\begin{array}{c}0.17 \\
(0.45)\end{array}$ & 0.014 & Black & $\begin{array}{c}0.33 \\
(0.48)\end{array}$ & 0.027 & Black & $\begin{array}{c}0.18 \\
(0.45)\end{array}$ & 0.015 & Black & $\begin{array}{l}1.00 * \\
(0.44)\end{array}$ & 0.084 \\
\hline Health Indicator & & & Health Indicator & & & Health Indicator & & & Health Indicator & & \\
\hline Obesity & $\begin{array}{l}5.55^{* * * *} \\
(1.23)\end{array}$ & 0.102 & Obesity & $\begin{array}{l}3.61 * * \\
(1.17)\end{array}$ & 0.066 & Obesity & $\begin{array}{l}4.63 * * * \\
(1.24)\end{array}$ & 0.085 & Obesity & $\begin{array}{l}4.70^{* * * *} \\
(1.21)\end{array}$ & 0.086 \\
\hline $\begin{array}{l}\text { Physical } \\
\text { Activity }\end{array}$ & $\begin{array}{l}-3.72^{* * * *} \\
(0.68) \\
\end{array}$ & -0.153 & $\begin{array}{l}\text { Physical } \\
\text { Activity }\end{array}$ & $\begin{array}{l}-3.93 * * * \\
(0.63) \\
\end{array}$ & -0.162 & $\begin{array}{l}\text { Physical } \\
\text { Activity }\end{array}$ & $\begin{array}{l}-4.41 * * * \\
(0.63) \\
\end{array}$ & -0.182 & $\begin{array}{l}\text { Physical } \\
\text { Activity }\end{array}$ & $\begin{array}{l}-4.89 * * * \\
(0.57) \\
\end{array}$ & -0.201 \\
\hline Smoking & $\begin{array}{l}18.95 * * * \\
(0.97)\end{array}$ & 0.430 & Smoking & $\begin{array}{l}17.70 * * * \\
(0.94)\end{array}$ & 0.402 & Smoking & $\begin{array}{l}18.43 * * * \\
(0.97)\end{array}$ & 0.418 & Smoking & $\begin{array}{l}22.33 * * * \\
(0.91)\end{array}$ & 0.507 \\
\hline Labor Force & & & Labor Force & & & Labor Force & & & Labor Force & & \\
\hline $\begin{array}{l}\text { Unemployed } \\
\text { (rate) }\end{array}$ & $\begin{array}{l}0.74 * * * \\
(0.10)\end{array}$ & 0.128 & $\begin{array}{l}\text { Unemployed } \\
\text { (rate) }\end{array}$ & $\begin{array}{l}0.78^{* * * *} \\
(0.09)\end{array}$ & 0.136 & $\begin{array}{l}\text { Unemployed } \\
\text { (rate) }\end{array}$ & $\begin{array}{l}0.70^{* * * *} \\
(0.10)\end{array}$ & 0.122 & \begin{tabular}{|l}
$\begin{array}{l}\text { Unemployed } \\
\text { (rate) }\end{array}$ \\
\end{tabular} & $\begin{array}{l}0.61 * * * \\
(0.09)\end{array}$ & 0.106 \\
\hline $\mathbf{N}$ & \multicolumn{2}{|c|}{3,070} & $\mathbf{N}$ & \multicolumn{2}{|c|}{3,070} & $\mathbf{N}$ & \multicolumn{2}{|c|}{3,070} & $\mathbf{N}$ & \multicolumn{2}{|c|}{3,070} \\
\hline Adj. $\mathbf{R}^{2}$ & \multicolumn{2}{|c|}{0.6269} & Adj. $\mathbf{R}^{2}$ & \multicolumn{2}{|c|}{0.6335} & Adj. $\mathbf{R}^{2}$ & \multicolumn{2}{|c|}{0.6210} & Adj. $\mathbf{R}^{2}$ & \multicolumn{2}{|c|}{0.6073} \\
\hline AIC & \multicolumn{2}{|c|}{37252.57} & AIC & \multicolumn{2}{|c|}{37199.73} & AIC & \multicolumn{2}{|c|}{37299.14} & AIC & \multicolumn{2}{|c|}{37401.42} \\
\hline BIC & \multicolumn{2}{|c|}{37361.1} & BIC & \multicolumn{2}{|c|}{37320.32} & BIC & \multicolumn{2}{|c|}{37401.64} & BIC & \multicolumn{2}{|c|}{37461.71} \\
\hline
\end{tabular}

Note. Coefficients with robust standard error in parentheses. ${ }^{*} \mathrm{p}<0.05, * * \mathrm{p}<0.01, * * * \mathrm{p}<0.001$

Dependent variable: Female mortality (rates) in 2010 (2008-2012)

${ }^{\mathrm{a}}=$ Age $25+;(\%)$ 
Table 11. Model 3b: Female Mortality with "People" Mediators

\begin{tabular}{|c|c|c|c|c|c|c|c|c|c|c|c|}
\hline \multirow{2}{*}{ Mortality } & \multicolumn{2}{|c|}{ Census } & \multirow{2}{*}{ Mortality } & \multicolumn{2}{|c|}{ Woodard } & \multirow{2}{*}{ Mortality } & \multicolumn{2}{|c|}{ Garreau } & \multirow{2}{*}{ Mortality } & \multicolumn{2}{|c|}{ No Regions } \\
\hline & Coef & Beta & & Coef & Beta & & Coef & Beta & & Coef & Beta \\
\hline Intercept & $\begin{array}{l}498.94 * * * \\
(77.51)\end{array}$ & -- & Intercept & $\begin{array}{l}588.90^{* * * *} \\
(77.70)\end{array}$ & -- & Intercept & $\begin{array}{l}621.88 * * * \\
(82.58)\end{array}$ & -- & Intercept & $\begin{array}{l}637.03 * * * \\
(78.49)\end{array}$ & -- \\
\hline Region & & & Region & & & Region & & & Region & & \\
\hline $\begin{array}{l}\text { New England } \\
\text { (ref) }\end{array}$ & 0 & 0 & Yankeedom (ref) & 0 & 0 & $\begin{array}{l}\text { New England } \\
\text { (ref) }\end{array}$ & 0 & 0 & - & -- & -- \\
\hline Mid Atlantic & $\begin{array}{c}-25.02 * * * \\
(6.84) \\
\end{array}$ & -0.045 & Deep South & $\begin{array}{l}60.13 * * * \\
(6.99) \\
\end{array}$ & 0.186 & $\begin{array}{l}\text { The Empty } \\
\text { Quarter }\end{array}$ & $\begin{array}{l}-0.53 \\
(9.68) \\
\end{array}$ & -0.001 & & & \\
\hline $\begin{array}{l}\text { East North } \\
\text { Central }\end{array}$ & $\begin{array}{l}-6.11 \\
(6.81) \\
\end{array}$ & -0.018 & El Norte & $\begin{array}{l}-11.96 \\
(12.66) \\
\end{array}$ & -0.016 & Ecotopia & $\begin{array}{c}1.58 \\
(9.28) \\
\end{array}$ & 0.002 & & & \\
\hline $\begin{array}{l}\text { West North } \\
\text { Central }\end{array}$ & $\begin{array}{c}-15.61^{*} \\
(7.23) \\
\end{array}$ & -0.052 & Far West & $\begin{array}{l}19.85^{* *} \\
(6.67) \\
\end{array}$ & 0.056 & Breadbasket & $\begin{array}{l}-6.83 \\
(7.28) \\
\end{array}$ & -0.026 & & & \\
\hline South Atlantic & $\begin{array}{l}20.90^{* * *} \\
(7.36)\end{array}$ & 0.069 & $\begin{array}{l}\text { Greater } \\
\text { Appalachia }\end{array}$ & $\begin{array}{l}59.58^{* * * *} \\
(4.65)\end{array}$ & 0.228 & MexAmerica & $\begin{array}{l}-42.17 * * * \\
(10.70)\end{array}$ & -0.072 & & & \\
\hline $\begin{array}{l}\text { East South } \\
\text { Central }\end{array}$ & $\begin{array}{l}50.17 * * * \\
(8.86)\end{array}$ & 0.135 & Left Coast & $\begin{array}{l}13.09 \\
(7.34) \\
\end{array}$ & 0.014 & The Foundry & $\begin{array}{r}-11.08 \\
(6.78) \\
\end{array}$ & -0.032 & & & \\
\hline $\begin{array}{l}\text { West South } \\
\text { Central }\end{array}$ & $\begin{array}{l}53.42 * * * \\
(8.14) \\
\end{array}$ & 0.160 & Midlands & $\begin{array}{l}18.30^{* * * *} \\
(4.51)\end{array}$ & 0.055 & Dixie & $\begin{array}{l}17.64^{*} \\
(7.47) \\
\end{array}$ & 0.072 & & & \\
\hline Mountain & $\begin{array}{l}25.76 * * \\
(9.78)\end{array}$ & 0.061 & New France & $\begin{array}{c}38.72 * \\
(16.04)\end{array}$ & 0.029 & The Islands & $\begin{array}{l}-140.68 * * * \\
(16.05)\end{array}$ & -0.056 & & & \\
\hline \multirow[t]{3}{*}{ Pacific } & $\begin{array}{l}-2.76 \\
(9.06)\end{array}$ & -0.005 & New Netherlands & $\begin{array}{l}-51.80^{* * * *} \\
(13.18)\end{array}$ & -0.038 & & & & & & \\
\hline & & & $\begin{array}{l}\text { Spanish } \\
\text { Caribbean }\end{array}$ & $\begin{array}{l}-54.85^{*} \\
(27.13) \\
\end{array}$ & -0.029 & & & & & & \\
\hline & & & Tidewater & $\begin{array}{l}16.34^{*} \\
(6.82)\end{array}$ & 0.029 & & & & & & \\
\hline Medical Care & & & Medical Care & & & Medical Care & & & Medical Care & & \\
\hline $\begin{array}{l}\text { No Health Ins } \\
(\%)\end{array}$ & $\begin{array}{l}-0.00 \\
(0.66)\end{array}$ & -0.000 & $\begin{array}{l}\text { No Health Ins } \\
(\%)\end{array}$ & $\begin{array}{l}1.69 * * \\
(0.59)\end{array}$ & 0.070 & $\begin{array}{l}\text { No Health Ins } \\
(\%)\end{array}$ & $\begin{array}{l}2.88 * * * \\
(0.57)\end{array}$ & 0.119 & $\begin{array}{l}\text { No Health Ins } \\
(\%)\end{array}$ & $\begin{array}{l}2.51 * * * \\
(0.52)\end{array}$ & 0.104 \\
\hline Education & & & Education & & & Education & & & Education & & \\
\hline$<\mathrm{HS}^{\mathrm{a}}$ (ref) & 0 & 0 & $<\mathrm{HS}^{\mathrm{a}}(\mathrm{ref})$ & 0 & 0 & $<\mathrm{HS}^{\mathrm{a}}(\mathrm{ref})$ & 0 & 0 & $<\mathrm{HS}^{\mathrm{a}}$ (ref) & 0 & 0 \\
\hline $\begin{array}{l}\text { HS/Some } \\
\text { College }\end{array}$ & $\begin{array}{c}1.12^{*} \\
(0.52)\end{array}$ & 0.064 & $\begin{array}{l}\text { HS/Some } \\
\text { College }\end{array}$ & $\begin{array}{c}0.13 \\
(0.50)\end{array}$ & 0.007 & $\begin{array}{l}\text { HS/Some } \\
\text { College }\end{array}$ & $\begin{array}{c}0.54 \\
(0.52)\end{array}$ & 0.031 & $\begin{array}{l}\text { HS/Some } \\
\text { College }\end{array}$ & $\begin{array}{c}0.33 \\
(0.49)\end{array}$ & 0.019 \\
\hline 4yr College + & $\begin{array}{c}0.81 \\
(0.56)\end{array}$ & 0.048 & 4yr College + & $\begin{array}{c}0.10 \\
(0.57)\end{array}$ & 0.006 & 4yr College + & $\begin{array}{c}0.49 \\
(0.58)\end{array}$ & 0.029 & 4yr College + & $\begin{array}{c}0.47 \\
(0.57)\end{array}$ & 0.028 \\
\hline
\end{tabular}




\begin{tabular}{|c|c|c|c|c|c|c|c|c|c|c|c|}
\hline Race & & & Race & & & Race & & & Race & & \\
\hline Other (ref) & 0 & 0 & Other (ref) & 0 & 0 & Other (ref) & 0 & 0 & Other (ref) & 0 & 0 \\
\hline White & $\begin{array}{l}-1.96 * * * \\
(0.48) \\
\end{array}$ & -0.261 & White & $\begin{array}{l}-1.98 * * * \\
(0.48) \\
\end{array}$ & -0.264 & White & $\begin{array}{l}-1.75 * * * \\
(0.48) \\
\end{array}$ & -0.233 & White & $\begin{array}{l}-1.76^{* * * *} \\
(0.48) \\
\end{array}$ & -0.235 \\
\hline Black & $\begin{array}{l}-1.18^{*} \\
(0.52)\end{array}$ & -0.148 & Black & $\begin{array}{l}-1.13 * \\
(0.53)\end{array}$ & -0.142 & Black & $\begin{array}{l}-1.09^{*} \\
(0.52)\end{array}$ & -0.137 & Black & $\begin{array}{l}-0.56 \\
(0.51)\end{array}$ & -0.070 \\
\hline Health Indicator & & & Health Indicator & & & Health Indica & & & & & \\
\hline Obesity & $\begin{array}{l}3.92 * * * \\
(0.78)\end{array}$ & 0.165 & Obesity & $\begin{array}{l}2.43^{* *} \\
(0.80)\end{array}$ & 0.102 & Obesity & $\begin{array}{c}1.96^{*} \\
(0.83)\end{array}$ & 0.083 & Obesity & $\begin{array}{c}1.38 \\
(0.82)\end{array}$ & 0.058 \\
\hline $\begin{array}{l}\text { Physical } \\
\text { Activity }\end{array}$ & $\begin{array}{l}-2.85 * * * \\
(0.49) \\
\end{array}$ & -0.190 & $\begin{array}{l}\text { Physical } \\
\text { Activity }\end{array}$ & $\begin{array}{l}-2.51 * * * \\
(0.49) \\
\end{array}$ & -0.167 & $\begin{array}{l}\text { Physical } \\
\text { Activity }\end{array}$ & $\begin{array}{l}-3.89 * * * \\
(0.48) \\
\end{array}$ & -0.259 & $\begin{array}{l}\text { Physical } \\
\text { Activity }\end{array}$ & $\begin{array}{l}-4.21 * * * \\
(0.42) \\
\end{array}$ & -0.281 \\
\hline Smoking & $\begin{array}{l}13.21 \text { *** } \\
(0.70)\end{array}$ & 0.417 & Smoking & $\begin{array}{l}11.81 \text { *** } \\
(0.71)\end{array}$ & 0.373 & Smoking & $\begin{array}{l}12.07 * * * \\
(0.76)\end{array}$ & 0.381 & Smoking & $\begin{array}{l}13.81 \text { *** } \\
(0.71)\end{array}$ & 0.436 \\
\hline Labor Force & & & Labor Force & & & Labor Force & & & Labor Force & & \\
\hline $\begin{array}{l}\text { Unemployed } \\
\text { (rate) }\end{array}$ & $\begin{array}{l}0.45^{* * * *} \\
(0.09) \\
\end{array}$ & 0.106 & $\begin{array}{l}\text { Unemployed } \\
\text { (rate) }\end{array}$ & $\begin{array}{l}0.47 \text { *** } \\
(0.09)\end{array}$ & 0.109 & $\begin{array}{l}\text { Unemployed } \\
\text { (rate) }\end{array}$ & $\begin{array}{l}0.46^{* * * *} \\
(0.09) \\
\end{array}$ & 0.108 & $\begin{array}{l}\text { Unemployed } \\
\text { (rate) }\end{array}$ & $\begin{array}{l}0.44 * * * \\
(0.09) \\
\end{array}$ & 0.103 \\
\hline $\mathbf{N}$ & & & $\mathbf{N}$ & 3,0 & & $\mathbf{N}$ & 3,0 & & $\mathbf{N}$ & 3, & \\
\hline Adj. $\mathbf{R}^{2}$ & 0.60 & & Adj. $R^{2}$ & 0.605 & & Adj. $R^{2}$ & 0.591 & & Adj. $\mathbf{R}^{2}$ & 0.579 & \\
\hline AIC & 352 & & AIC & 352 & & AIC & 3536 & & AIC & 354 & \\
\hline BIC & 353 & & BIC & 353 & & BIC & 3546 & .29 & BIC & 355 & \\
\hline
\end{tabular}

Note. Coefficients with robust standard error in parentheses. ${ }^{*} \mathrm{p}<0.05, * * \mathrm{p}<0.01,{ }^{*} * *_{\mathrm{p}}<0.001$

Dependent variable: Female mortality (rates) in 2010 (2008-2012)

${ }^{\mathrm{a}}=$ Age $25+;(\%)$ 
Table 12. Model 4a: Male Mortality with Mediators (except Smoking and LFP ${ }^{\mathrm{a}}$ )

\begin{tabular}{|c|c|c|c|c|c|c|c|c|}
\hline \multirow{2}{*}{ Mortality } & \multicolumn{2}{|c|}{ Census } & \multirow{2}{*}{ Mortality } & \multicolumn{2}{|c|}{ Woodard } & \multirow{2}{*}{ Mortality } & \multicolumn{2}{|c|}{ Garreau } \\
\hline & Coef & Beta & & Coef & Beta & & Coef & Beta \\
\hline Intercept & $\begin{array}{l}893.61 * * * \\
(98.87)\end{array}$ & -- & Intercept & $\begin{array}{l}1023.11^{* * * *} \\
(101.66)\end{array}$ & -- & Intercept & $\begin{array}{l}910.74 * * * \\
(100.46)\end{array}$ & -- \\
\hline Region & & & Region & & & Region & & \\
\hline $\begin{array}{l}\text { New England } \\
\text { (ref) }\end{array}$ & 0 & 0 & Yankeedom (ref) & 0 & 0 & $\begin{array}{l}\text { New England } \\
\text { (ref) }\end{array}$ & 0 & 0 \\
\hline Mid Atlantic & $\begin{array}{l}-64.15^{* * * *} \\
(10.59) \\
\end{array}$ & -0.081 & Deep South & $\begin{array}{l}67.07 * * * \\
(9.70)\end{array}$ & 0.145 & $\begin{array}{l}\text { The Empty } \\
\text { Quarter }\end{array}$ & $\begin{array}{l}-85.60 * * * \\
(12.31) \\
\end{array}$ & -0.132 \\
\hline $\begin{array}{l}\text { East North } \\
\text { Central }\end{array}$ & $\begin{array}{c}-36.48 * * * \\
(9.72)\end{array}$ & -0.075 & El Norte & $\begin{array}{l}-48.76^{* *} \\
(18.00)\end{array}$ & -0.047 & Ecotopia & $\begin{array}{l}-71.47 * * * \\
(12.92)\end{array}$ & -0.059 \\
\hline $\begin{array}{l}\text { West North } \\
\text { Central }\end{array}$ & $\begin{array}{l}-78.32 * * * * \\
(10.89)\end{array}$ & -0.183 & Far West & $\begin{array}{c}8.06 \\
(8.62)\end{array}$ & 0.016 & Breadbasket & $\begin{array}{c}-75.64 * * * \\
(9.91)\end{array}$ & -0.204 \\
\hline South Atlantic & $\begin{array}{c}-5.81 \\
(10.48) \\
\end{array}$ & -0.013 & $\begin{array}{l}\text { Greater } \\
\text { Appalachia }\end{array}$ & $\begin{array}{l}93.35^{* * * *} \\
(6.38) \\
\end{array}$ & 0.251 & MexAmerica & $\begin{array}{l}-146.80 * * * \\
(14.27) \\
\end{array}$ & -0.177 \\
\hline $\begin{array}{l}\text { East South } \\
\text { Central }\end{array}$ & $\begin{array}{l}66.37 * * * * \\
(12.67) \\
\end{array}$ & 0.126 & Left Coast & $\begin{array}{c}6.20 \\
(11.97) \\
\end{array}$ & 0.005 & The Foundry & $\begin{array}{c}-40.38 * * * \\
(9.45) \\
\end{array}$ & -0.082 \\
\hline $\begin{array}{l}\text { West South } \\
\text { Central }\end{array}$ & $\begin{array}{l}-12.66 \\
(11.96) \\
\end{array}$ & -0.027 & Midlands & $\begin{array}{l}16.84 * * \\
(6.48)\end{array}$ & 0.035 & Dixie & $\begin{array}{c}12.39 \\
(10.09) \\
\end{array}$ & 0.036 \\
\hline Mountain & $\begin{array}{l}-51.07 * * * \\
(13.23)\end{array}$ & -0.085 & New France & $\begin{array}{l}14.65 \\
(21.56)\end{array}$ & 0.008 & The Islands & $\begin{array}{l}-189.95 * * * \\
(28.41)\end{array}$ & -0.053 \\
\hline Pacific & $\begin{array}{l}-87.94 * * * \\
(11.98)\end{array}$ & -0.105 & New Netherlands & $\begin{array}{l}-83.11 * * * \\
(21.66)\end{array}$ & -0.043 & & & \\
\hline & & & $\begin{array}{l}\text { Spanish } \\
\text { Caribbean }\end{array}$ & $\begin{array}{l}-82.33 * * \\
(30.94) \\
\end{array}$ & -0.030 & & & \\
\hline & & & Tidewater & $\begin{array}{l}31.62 * * \\
(11.31)\end{array}$ & 0.039 & & & \\
\hline RUC Code $^{b}$ & & & RUC Code $^{\mathrm{b}}$ & & & RUC Code $^{\mathrm{b}}$ & & \\
\hline 1 (ref) & 0 & 0 & 1 (ref) & 0 & 0 & 1 (ref) & 0 & 0 \\
\hline 2 & \begin{tabular}{|l|}
-7.76 \\
$(6.94)$ \\
\end{tabular} & -0.014 & 2 & $\begin{array}{l}-7.56 \\
(6.88) \\
\end{array}$ & -0.014 & 2 & $\begin{array}{r}-14.89^{*} \\
(6.89) \\
\end{array}$ & -0.027 \\
\hline 3 & $\begin{array}{r}-11.15 \\
(7.31)\end{array}$ & -0.021 & 3 & $\begin{array}{r}-12.84 \\
(7.21)\end{array}$ & -0.024 & 3 & $\begin{array}{r}-13.44 \\
(7.33)\end{array}$ & -0.025 \\
\hline 4 & $\begin{array}{l}-1.02 \\
(7.95)\end{array}$ & -0.002 & 4 & $\begin{array}{c}3.28 \\
(7.84)\end{array}$ & 0.005 & 4 & $\begin{array}{l}-6.20 \\
(7.84)\end{array}$ & -0.009 \\
\hline 5 & $\begin{array}{l}25.77^{*} \\
(11.74)\end{array}$ & 0.027 & 5 & $\begin{array}{c}18.24 \\
(11.42)\end{array}$ & 0.019 & 5 & $\begin{array}{c}16.98 \\
(11.72)\end{array}$ & 0.018 \\
\hline 6 & $\begin{array}{l}-9.23 \\
(7.33)\end{array}$ & -0.022 & 6 & $\begin{array}{c}-13.91 \\
(7.34)\end{array}$ & -0.033 & 6 & $\begin{array}{r}-15.48^{*} \\
(7.36)\end{array}$ & -0.036 \\
\hline 7 & $\begin{array}{c}-15.41 \\
(8.27)\end{array}$ & -0.032 & 7 & $\begin{array}{c}-15.21 \\
(8.14)\end{array}$ & -0.031 & 7 & $\begin{array}{c}-23.78 * * \\
(7.94)\end{array}$ & -0.049 \\
\hline 8 & $\begin{array}{l}-36.32 * * \\
(10.78)\end{array}$ & -0.056 & 8 & $\begin{array}{l}-35.41 * * \\
(10.67)\end{array}$ & -0.054 & 8 & $\begin{array}{l}-41.34 * * * \\
(10.58)\end{array}$ & -0.063 \\
\hline 9 & $\begin{array}{l}-29.25 * * \\
(10.45)\end{array}$ & -0.058 & 9 & $\begin{array}{l}-27.51 * * \\
(10.30)\end{array}$ & -0.054 & 9 & $\begin{array}{l}-43.06^{* * * *} \\
(10.14)\end{array}$ & -0.085 \\
\hline Typology $^{\mathrm{c}}$ & & & Typology ${ }^{\mathbf{c}}$ & & & Typology $^{\mathrm{c}}$ & & \\
\hline $\begin{array}{l}\text { Non-dependent } \\
\text { (ref) }\end{array}$ & 0 & 0 & $\begin{array}{l}\text { Non-dependent } \\
\text { (ref) }\end{array}$ & 0 & 0 & $\begin{array}{l}\text { Non-dependent } \\
\text { (ref) }\end{array}$ & 0 & 0 \\
\hline Farming & $\begin{array}{l}-60.50 * * * \\
(8.69)\end{array}$ & -0.121 & Farming & $\begin{array}{l}-62.97 * * * \\
(8.59)\end{array}$ & -0.126 & Farming & $\begin{array}{l}-65.73 * * * \\
(8.69)\end{array}$ & -0.132 \\
\hline Mining & $\begin{array}{l}46.83 * * * \\
(11.91)\end{array}$ & 0.054 & Mining & $\begin{array}{l}46.62 * * * \\
(12.04)\end{array}$ & 0.054 & Mining & $\begin{array}{l}51.85^{* * * *} \\
(11.85)\end{array}$ & 0.060 \\
\hline Manufacturing & $\begin{array}{c}5.66 \\
(4.90)\end{array}$ & 0.015 & Manufacturing & $\begin{array}{l}12.92 * * \\
(4.80)\end{array}$ & 0.034 & Manufacturing & $\begin{array}{l}10.12^{*} \\
(4.80)\end{array}$ & 0.027 \\
\hline
\end{tabular}




\begin{tabular}{|c|c|c|c|c|c|c|c|c|}
\hline Government & $\begin{array}{l}-9.22 \\
(7.30)\end{array}$ & -0.018 & Government & $\begin{array}{l}-3.40 \\
(7.33)\end{array}$ & -0.006 & Government & $\begin{array}{l}-4.89 \\
(7.28)\end{array}$ & -0.009 \\
\hline Service & $\begin{array}{r}-17.22^{*} \\
(6.93)\end{array}$ & -0.031 & Service & $\begin{array}{l}-7.99 \\
(6.93)\end{array}$ & -0.015 & Service & $\begin{array}{c}-20.88^{* *} \\
(7.07)\end{array}$ & -0.038 \\
\hline Medical Care & & & Medical Care & & & Medical Care & & \\
\hline $\begin{array}{l}\text { Active MDs } \\
\text { (rate) }\end{array}$ & $\begin{array}{l}11.15 * * * \\
(2.36)\end{array}$ & 0.088 & $\begin{array}{l}\text { Active MDs } \\
\text { (rate) }\end{array}$ & $\begin{array}{l}11.70 * * * * \\
(2.52)\end{array}$ & 0.092 & $\begin{array}{l}\text { Active MDs } \\
\text { (rate) }\end{array}$ & $\begin{array}{l}8.01 * * * * \\
(2.22)\end{array}$ & 0.069 \\
\hline $\begin{array}{l}\text { Hospital Beds } \\
\text { (rate) }\end{array}$ & $\begin{array}{l}1.76 * * \\
(0.51)\end{array}$ & 0.053 & $\begin{array}{l}\text { Hospital Beds } \\
\text { (rate) }\end{array}$ & $\begin{array}{l}1.59 * * \\
(0.49)\end{array}$ & 0.048 & $\begin{array}{l}\text { Hospital Beds } \\
\text { (rate) }\end{array}$ & $\begin{array}{l}1.73 * * * \\
(0.49)\end{array}$ & 0.052 \\
\hline $\begin{array}{l}\text { No Health Ins } \\
(\%)\end{array}$ & $\begin{array}{l}1.55 \\
(1.00)\end{array}$ & 0.045 & $\begin{array}{l}\text { No Health Ins } \\
(\%)\end{array}$ & $\begin{array}{l}1.94 * \\
(0.89) \\
\end{array}$ & 0.056 & $\begin{array}{l}\text { No Health Ins } \\
(\%)\end{array}$ & $\begin{array}{l}5.11 * * * \\
(0.85) \\
\end{array}$ & 0.148 \\
\hline Education & & & Education & & & Education & & \\
\hline$<\mathrm{HS}^{\mathrm{d}}($ ref $)$ & 0 & 0 & $<\mathrm{HS}^{\mathrm{d}}(\mathrm{ref})$ & 0 & 0 & $<\mathrm{HS}^{\mathrm{d}}(\mathrm{ref})$ & 0 & 0 \\
\hline $\begin{array}{l}\text { HS/Some } \\
\text { College }\end{array}$ & $\begin{array}{l}4.08 * * * \\
(0.66) \\
\end{array}$ & 0.177 & $\begin{array}{l}\text { HS/Some } \\
\text { College }\end{array}$ & $\begin{array}{l}2.57 * * * * \\
(0.62) \\
\end{array}$ & 0.112 & $\begin{array}{l}\text { HS/Some } \\
\text { College }\end{array}$ & $\begin{array}{l}4.10^{* * * *} \\
(0.61)\end{array}$ & 0.178 \\
\hline 4yr College + & $\begin{array}{l}-3.84 * * * * \\
(0.65)\end{array}$ & -0.196 & 4yr College + & $\begin{array}{l}-4.52 * * * * \\
(0.62)\end{array}$ & -0.230 & 4yr College + & $\begin{array}{l}-2.92^{* * * *} \\
(0.64)\end{array}$ & -0.148 \\
\hline Race & & & Race & & & Race & & \\
\hline Other (ref) & 0 & 0 & Other (ref) & 0 & 0 & Other (ref) & 0 & 0 \\
\hline White & $\begin{array}{l}-3.69 * * * \\
(0.51)\end{array}$ & -0.331 & White & $\begin{array}{l}-3.60 * * * \\
(0.51)\end{array}$ & -0.323 & White & $\begin{array}{l}-3.14 * * * \\
(0.49)\end{array}$ & -0.282 \\
\hline Black & $\begin{array}{l}-2.46 * * * \\
(0.52) \\
\end{array}$ & -0.207 & Black & $\begin{array}{l}-1.77 * * \\
(0.56) \\
\end{array}$ & -0.149 & Black & $\begin{array}{l}-2.55 * * * \\
(0.51) \\
\end{array}$ & -0.215 \\
\hline Health Indicator & & & Health Indicator & & & Health Indicator & & \\
\hline Obesity & $\begin{array}{l}9.07 * * * * \\
(1.33)\end{array}$ & 0.167 & Obesity & $\begin{array}{l}6.09 * * * \\
(1.27)\end{array}$ & 0.112 & Obesity & $\begin{array}{l}7.14 * * * \\
(1.36) \\
\end{array}$ & 0.131 \\
\hline $\begin{array}{l}\text { Physical } \\
\text { Activity }\end{array}$ & $\begin{array}{l}-5.80 * * * \\
(0.71) \\
\end{array}$ & -0.239 & $\begin{array}{l}\text { Physical } \\
\text { Activity }\end{array}$ & $\begin{array}{l}-5.99 * * * \\
(0.66) \\
\end{array}$ & -0.246 & $\begin{array}{l}\text { Physical } \\
\text { Activity }\end{array}$ & $\begin{array}{l}-6.93 * * * \\
(0.65) \\
\end{array}$ & -0.285 \\
\hline Inequality & & & Inequality & & & Inequality & & \\
\hline $\mathrm{Gini}^{\mathrm{e}}$ & $\begin{array}{l}6.99 * * * \\
(0.93)\end{array}$ & 0.158 & $\mathrm{Gini}^{\mathrm{e}}$ & $\begin{array}{l}6.41 * * * \\
(0.94) \\
\end{array}$ & 0.145 & $\mathrm{Gini}^{\mathrm{e}}$ & $\begin{array}{l}7.02 * * * \\
(0.92) \\
\end{array}$ & 0.159 \\
\hline $\mathbf{N}$ & \multicolumn{2}{|c|}{3,070} & $\mathbf{N}$ & \multicolumn{2}{|c|}{3,070} & $\mathbf{N}$ & \multicolumn{2}{|c|}{3,070} \\
\hline Adj. $\mathbf{R}^{2}$ & \multicolumn{2}{|c|}{0.6022} & Adj. $\mathbf{R}^{2}$ & \multicolumn{2}{|c|}{0.6103} & Adj. $\mathbf{R}^{2}$ & \multicolumn{2}{|c|}{0.6068} \\
\hline AIC & \multicolumn{2}{|c|}{37463.17} & AIC & \multicolumn{2}{|c|}{37401.43} & AIC & \multicolumn{2}{|c|}{37425.93} \\
\hline BIC & \multicolumn{2}{|c|}{37656.11} & BIC & \multicolumn{2}{|c|}{37606.43} & BIC & \multicolumn{2}{|c|}{37612.84} \\
\hline
\end{tabular}

Note. Coefficients with robust standard error in parentheses. ${ }^{*} \mathrm{p}<0.05,{ }^{* *} \mathrm{p}<0.01,{ }^{*} * * \mathrm{p}<0.001$

Dependent variable: Female mortality (rates) in 2010 (2008-2012)

${ }^{\mathrm{a}}=$ Labor Force Participation

${ }^{\mathrm{b}}=$ Rural Urban Continuum Code (2003)

${ }^{c}=(2004) ;($ all other control variables are 2000 unless otherwise noted $)$

$\mathrm{d}=$ Age $25+;(\%)$

${ }^{\mathrm{e}}=$ Gini Index multiplied times 100 to see increment changes 
Table 13. Model 4b: Female Mortality with Mediators (except Smoking and LFP ${ }^{\mathrm{a}}$ )

\begin{tabular}{|c|c|c|c|c|c|c|c|c|}
\hline \multirow{2}{*}{ Mortality } & \multicolumn{2}{|c|}{ Census } & \multirow{2}{*}{ Mortality } & \multicolumn{2}{|c|}{ Woodard } & \multirow{2}{*}{ Mortality } & \multicolumn{2}{|c|}{ Garreau } \\
\hline & Coef & Beta & & Coef & Beta & & Coef & Beta \\
\hline Intercept & $\begin{array}{l}849.54 * * * \\
(87.54)\end{array}$ & -- & Intercept & $\begin{array}{l}862.82 * * * \\
(85.28)\end{array}$ & -- & Intercept & $\begin{array}{l}814.04 * * * \\
(88.87)\end{array}$ & -- \\
\hline Region & & & Region & & & Region & & \\
\hline $\begin{array}{l}\text { New England } \\
\text { (ref) }\end{array}$ & 0 & 0 & Yankeedom (ref) & 0 & 0 & $\begin{array}{l}\text { New England } \\
\text { (ref) }\end{array}$ & 0 & 0 \\
\hline Mid Atlantic & $\begin{array}{c}-44.62 * * \\
(7.67)\end{array}$ & -0.080 & Deep South & $\begin{array}{l}54.30 * * * \\
(7.16)\end{array}$ & 0.168 & $\begin{array}{l}\text { The Empty } \\
\text { Quarter }\end{array}$ & $\begin{array}{c}-34.16^{* * * *} \\
(9.51)\end{array}$ & -0.075 \\
\hline $\begin{array}{l}\text { East North } \\
\text { Central }\end{array}$ & $\begin{array}{l}-26.66 * * * \\
(7.26)\end{array}$ & -0.078 & El Norte & $\begin{array}{l}-82.13 * * * \\
(13.49)\end{array}$ & -0.113 & Ecotopia & $\begin{array}{l}-35.38 * * * \\
(10.06)\end{array}$ & -0.041 \\
\hline $\begin{array}{l}\text { West North } \\
\text { Central }\end{array}$ & $\begin{array}{l}-56.06^{* * * *} \\
(7.73)\end{array}$ & -0.186 & Far West & $\begin{array}{l}12.81 \\
(6.74)\end{array}$ & 0.036 & Breadbasket & $\begin{array}{c}-42.82 * * * \\
(7.30)\end{array}$ & -0.164 \\
\hline South Atlantic & $\begin{array}{c}1.05 \\
(7.84)\end{array}$ & 0.003 & $\begin{array}{l}\text { Greater } \\
\text { Appalachia }\end{array}$ & $\begin{array}{l}59.00 * * * \\
(4.93)\end{array}$ & 0.226 & MexAmerica & $\begin{array}{l}-119.19 * * * \\
(11.03)\end{array}$ & -0.205 \\
\hline $\begin{array}{l}\text { East South } \\
\text { Central }\end{array}$ & $\begin{array}{l}35.67 * * * \\
(9.37)\end{array}$ & 0.096 & Left Coast & $\begin{array}{l}-0.46 \\
(9.35)\end{array}$ & -0.001 & The Foundry & $\begin{array}{c}-24.36^{* *} \\
(7.19)\end{array}$ & -0.070 \\
\hline $\begin{array}{l}\text { West South } \\
\text { Central }\end{array}$ & $\begin{array}{l}10.22 \\
(8.66) \\
\end{array}$ & 0.031 & Midlands & $\begin{array}{l}11.48 * \\
(4.88) \\
\end{array}$ & 0.034 & Dixie & $\begin{array}{c}7.30 \\
(7.71) \\
\end{array}$ & 0.030 \\
\hline Mountain & $\begin{array}{c}-8.92 \\
(10.04) \\
\end{array}$ & -0.021 & New France & $\begin{array}{c}17.36 \\
(17.39) \\
\end{array}$ & 0.013 & The Islands & $\begin{array}{l}-183.39 * * * \\
(20.35)\end{array}$ & -0.073 \\
\hline Pacific & $\begin{array}{l}-39.67 * * * \\
(9.72)\end{array}$ & -0.067 & New Netherlands & $\begin{array}{l}-71.26 * * * \\
(16.34)\end{array}$ & -0.052 & & & \\
\hline & & & $\begin{array}{l}\text { Spanish } \\
\text { Caribbean }\end{array}$ & $\begin{array}{l}-68.95 * \\
(28.92) \\
\end{array}$ & -0.036 & & & \\
\hline & & & Tidewater & $\begin{array}{l}17.57 * \\
(7.16)\end{array}$ & 0.031 & & & \\
\hline RUC Code $^{\text {b }}$ & & & RUC Code $^{b}$ & & & RUC Code $^{b}$ & & \\
\hline 1 (ref) & 0 & 0 & 1 (ref) & 0 & 0 & 1 (ref) & 0 & 0 \\
\hline 2 & $\begin{array}{l}-9.08 \\
(5.29)\end{array}$ & -0.023 & 2 & $\begin{array}{c}-11.34 * \\
(5.02)\end{array}$ & -0.029 & 2 & $\begin{array}{c}-14.74 * * \\
(5.20)\end{array}$ & -0.038 \\
\hline 3 & $\begin{array}{l}-9.00 \\
(5.51)\end{array}$ & -0.024 & 3 & $\begin{array}{c}-16.22 * * \\
(5.17)\end{array}$ & -0.043 & 3 & $\begin{array}{c}-15.50 * * \\
(5.39)\end{array}$ & -0.041 \\
\hline 4 & $\begin{array}{l}-4.97 \\
(6.00)\end{array}$ & -0.011 & 4 & $\begin{array}{l}-7.52 \\
(5.72)\end{array}$ & -0.016 & 4 & $\begin{array}{r}-12.38 * \\
(5.86)\end{array}$ & -0.027 \\
\hline 5 & $\begin{array}{l}17.27 * \\
(7.95)\end{array}$ & 0.026 & 5 & $\begin{array}{c}3.23 \\
(7.70)\end{array}$ & 0.005 & 5 & $\begin{array}{c}1.46 \\
(7.87)\end{array}$ & 0.002 \\
\hline 6 & $\begin{array}{l}-6.20 \\
(5.53) \\
\end{array}$ & -0.021 & 6 & $\begin{array}{c}-15.07 * * \\
(5.23)\end{array}$ & -0.050 & 6 & $\begin{array}{c}-16.06^{* * *} \\
(5.40)\end{array}$ & -0.053 \\
\hline 7 & $\begin{array}{l}-6.04 \\
(6.44) \\
\end{array}$ & -0.018 & 7 & $\begin{array}{r}-13.90 * \\
(5.91) \\
\end{array}$ & -0.041 & 7 & $\begin{array}{c}-19.82 * * \\
(6.11) \\
\end{array}$ & -0.058 \\
\hline 8 & $\begin{array}{c}-25.75^{* *} \\
(7.80)\end{array}$ & -0.056 & 8 & $\begin{array}{l}-33.41 * * * \\
(7.53)\end{array}$ & -0.073 & 8 & $\begin{array}{l}-37.18 * * * \\
(7.65)\end{array}$ & -0.081 \\
\hline 9 & $\begin{array}{r}-11.92 \\
(7.73)\end{array}$ & -0.033 & 9 & $\begin{array}{c}-21.78 * * \\
(7.15)\end{array}$ & -0.061 & 9 & $\begin{array}{l}-30.85 * * * \\
(7.37)\end{array}$ & -0.086 \\
\hline Typology & & & Typology $^{c}$ & & & Typology & & \\
\hline $\begin{array}{l}\text { Non-dependent } \\
\text { (ref) }\end{array}$ & 0 & 0 & $\begin{array}{l}\text { Non-dependent } \\
\text { (ref) }\end{array}$ & 0 & 0 & $\begin{array}{l}\text { Non-dependent } \\
\text { (ref) }\end{array}$ & 0 & 0 \\
\hline Farming & $\begin{array}{l}-39.75 * * * \\
(6.13)\end{array}$ & -0.113 & Farming & $\begin{array}{l}-44.93 * * * \\
(6.05)\end{array}$ & -0.128 & Farming & $\begin{array}{l}-45.89 * * * \\
(6.17)\end{array}$ & -0.131 \\
\hline Mining & $\begin{array}{l}36.81 * * * \\
(9.22)\end{array}$ & 0.061 & Mining & $\begin{array}{l}42.59 * * * \\
(9.09)\end{array}$ & 0.070 & Mining & $\begin{array}{l}42.70 * * * \\
(8.97)\end{array}$ & 0.071 \\
\hline Manufacturing & $\begin{array}{l}-1.08 \\
(3.67)\end{array}$ & -0.004 & Manufacturing & $\begin{array}{c}2.83 \\
(3.56)\end{array}$ & 0.011 & Manufacturing & $\begin{array}{c}1.40 \\
(3.61)\end{array}$ & 0.005 \\
\hline
\end{tabular}




\begin{tabular}{|c|c|c|c|c|c|c|c|c|}
\hline Government & $\begin{array}{l}-1.15 \\
(5.21)\end{array}$ & -0.003 & Government & $\begin{array}{c}6.85 \\
(5.01)\end{array}$ & 0.019 & Government & $\begin{array}{c}3.26 \\
(5.02)\end{array}$ & 0.009 \\
\hline Service & $\begin{array}{c}-18.73^{* * * *} \\
(5.15)\end{array}$ & -0.049 & Service & $\begin{array}{r}-11.89^{*} \\
(5.00)\end{array}$ & -0.031 & Service & $\begin{array}{c}-19.68 * * * \\
(5.16)\end{array}$ & -0.051 \\
\hline Medical Care & & & Medical Care & & & Medical Care & & \\
\hline $\begin{array}{l}\text { Active MDs } \\
\text { (rate) }\end{array}$ & $\begin{array}{c}2.98^{*} \\
(1.24)\end{array}$ & 0.033 & $\begin{array}{l}\text { Active MDs } \\
\text { (rate) }\end{array}$ & $\begin{array}{l}4.14 * * \\
(1.27)\end{array}$ & 0.046 & $\begin{array}{l}\text { Active MDs } \\
\text { (rate) }\end{array}$ & $\begin{array}{c}1.78 \\
(1.18)\end{array}$ & 0.020 \\
\hline $\begin{array}{l}\text { Hospital Beds } \\
\text { (rate) }\end{array}$ & $\begin{array}{c}0.92 * \\
(0.36)\end{array}$ & 0.040 & $\begin{array}{l}\text { Hospital Beds } \\
\text { (rate) }\end{array}$ & $\begin{array}{c}0.66 \\
(0.35)\end{array}$ & 0.028 & $\begin{array}{l}\text { Hospital Beds } \\
\text { (rate) }\end{array}$ & $\begin{array}{c}0.75^{*} \\
(0.35)\end{array}$ & 0.032 \\
\hline $\begin{array}{l}\text { No Health Ins } \\
(\%)\end{array}$ & $\begin{array}{l}-0.88 \\
(0.75) \\
\end{array}$ & -0.036 & $\begin{array}{l}\text { No Health Ins } \\
(\%)\end{array}$ & $\begin{array}{c}1.54 * \\
(0.65) \\
\end{array}$ & 0.064 & $\begin{array}{l}\text { No Health Ins } \\
(\%)\end{array}$ & $\begin{array}{l}3.22 * * * \\
(0.64) \\
\end{array}$ & 0.133 \\
\hline Education & & & Education & & & Education & & \\
\hline$<\mathrm{HS}^{\mathrm{d}}(\mathrm{ref})$ & 0 & 0 & $<\mathrm{HS}^{\mathrm{d}}$ (ref) & 0 & 0 & $<\mathrm{HS}^{\mathrm{d}}$ (ref) & 0 & 0 \\
\hline $\begin{array}{l}\text { HS/Some } \\
\text { College }\end{array}$ & $\begin{array}{l}3.39 * * * * \\
(0.63) \\
\end{array}$ & 0.195 & $\begin{array}{l}\text { HS/Some } \\
\text { College }\end{array}$ & $\begin{array}{l}1.52 * * \\
(0.58) \\
\end{array}$ & 0.087 & $\begin{array}{l}\text { HS/Some } \\
\text { College }\end{array}$ & $\begin{array}{l}2.69 * * * \\
(0.60) \\
\end{array}$ & 0.154 \\
\hline 4yr College + & $\begin{array}{l}-2.12 * * \\
(0.62) \\
\end{array}$ & -0.126 & 4yr College + & $\begin{array}{l}-3.08 * * * * \\
(0.60)\end{array}$ & -0.183 & 4yr College + & $\begin{array}{l}-2.01 * * \\
(0.61) \\
\end{array}$ & -0.119 \\
\hline Race & & & Race & & & Race & & \\
\hline Other (ref) & 0 & 0 & Other (ref) & 0 & 0 & Other (ref) & 0 & 0 \\
\hline White & $\begin{array}{l}-3.37 * * * \\
(0.53)\end{array}$ & -0.450 & White & $\begin{array}{l}-2.91 * * * \\
(0.53)\end{array}$ & -0.388 & White & $\begin{array}{l}-2.75 * * * \\
(0.52)\end{array}$ & -0.367 \\
\hline Black & $\begin{array}{l}-3.79 * * * * \\
(0.55)\end{array}$ & -0.476 & Black & $\begin{array}{l}-3.20 * * * * \\
(0.56)\end{array}$ & -0.402 & Black & $\begin{array}{l}-3.60 * * * \\
(0.54) \\
\end{array}$ & -0.452 \\
\hline Health Indicator & & & Health Indicator & & & Health Indicator & & \\
\hline Obesity & $\begin{array}{l}3.42 * * * \\
(0.91)\end{array}$ & 0.144 & Obesity & $\begin{array}{l}2.53 * * \\
(0.86) \\
\end{array}$ & 0.107 & Obesity & $\begin{array}{l}2.44 * * \\
(0.89) \\
\end{array}$ & 0.103 \\
\hline $\begin{array}{l}\text { Physical } \\
\text { Activity }\end{array}$ & $\begin{array}{l}-6.20 * * * * \\
(0.53) \\
\end{array}$ & -0.413 & $\begin{array}{l}\text { Physical } \\
\text { Activity }\end{array}$ & $\begin{array}{l}-5.02 * * * \\
(0.50) \\
\end{array}$ & -0.334 & $\begin{array}{l}\text { Physical } \\
\text { Activity }\end{array}$ & $\begin{array}{l}-6.08 * * * \\
(0.47) \\
\end{array}$ & -0.405 \\
\hline Inequality & & & Inequality & & & Inequality & & \\
\hline Gini $^{\mathrm{e}}$ & $\begin{array}{l}4.65^{* * * *} \\
(0.74) \\
\end{array}$ & .150 & Gini $^{\mathrm{e}}$ & $\begin{array}{l}4.08 * * * \\
(0.72) \\
\end{array}$ & 0.131 & Gini $^{\mathrm{e}}$ & $\begin{array}{l}4.80 * * * \\
(0.71)\end{array}$ & 0.155 \\
\hline $\mathbf{N}$ & \multicolumn{2}{|c|}{3,070} & $\mathbf{N}$ & \multicolumn{2}{|c|}{3,070} & $\mathbf{N}$ & \multicolumn{2}{|c|}{3,070} \\
\hline Adj. $\mathbf{R}^{2}$ & \multicolumn{2}{|c|}{0.5653} & Adj. $R^{2}$ & \multicolumn{2}{|c|}{0.5848} & Adj. $R^{2}$ & \multicolumn{2}{|c|}{0.5760} \\
\hline AIC & \multicolumn{2}{|c|}{35566.72} & AIC & \multicolumn{2}{|c|}{35428.11} & AIC & \multicolumn{2}{|c|}{35489.52} \\
\hline BIC & \multicolumn{2}{|c|}{35759.66} & BIC & \multicolumn{2}{|c|}{35633.11} & BIC & \multicolumn{2}{|c|}{35676.44} \\
\hline
\end{tabular}

Note. Coefficients with robust standard error in parentheses. ${ }^{*} \mathrm{p}<0.05,{ }^{*} \mathrm{p} \leq 0.01,{ }^{*} * \mathrm{p} \leq 0.001$

Dependent variable: Female mortality (rates) in 2010 (2008-2012)

${ }^{\mathrm{a}}=$ Labor Force Participation

${ }^{\mathrm{b}}=$ Rural Urban Continuum Code (2003)

${ }^{\mathrm{c}}=(2004) ;($ all other control variables are 2000 unless otherwise noted)

${ }^{\mathrm{d}}=$ Age $25+;(\%)$

${ }^{\mathrm{e}}=$ Gini Index multiplied times 100 to see increment changes 
Table 14. Model 5a: Male Mortality with All Mediators

\begin{tabular}{|c|c|c|c|c|c|c|c|c|c|c|c|}
\hline \multirow{2}{*}{ Mortality } & \multicolumn{2}{|c|}{ Census } & \multirow{2}{*}{ Mortality } & \multicolumn{2}{|c|}{ Woodard } & \multirow{2}{*}{ Mortality } & \multicolumn{2}{|c|}{ Garreau } & \multirow{2}{*}{ Mortality } & \multicolumn{2}{|c|}{ No Regions } \\
\hline & Coef & Beta & & Coef & Beta & & Coef & Beta & & Coef & Beta \\
\hline Intercept & $\begin{array}{l}224.58^{*} \\
(99.01)\end{array}$ & -- & Intercept & $\begin{array}{l}342.13^{* *} \\
(100.83)\end{array}$ & -- & Intercept & $\begin{array}{l}269.44 * * \\
(101.53)\end{array}$ & -- & Intercept & $\begin{array}{l}191.63 \\
(103.25)\end{array}$ & -- \\
\hline Region & & & Region & & & Region & & & Region & & \\
\hline $\begin{array}{l}\text { New England } \\
\text { (ref) }\end{array}$ & 0 & 0 & Yankeedom (ref) & 0 & 0 & $\begin{array}{l}\text { New England } \\
\text { (ref) }\end{array}$ & 0 & 0 & -- & -- & -- \\
\hline Mid Atlantic & $\begin{array}{l}-43.41 * * * \\
(9.73)\end{array}$ & -0.055 & Deep South & $\begin{array}{l}68.45 * * * \\
(9.70)\end{array}$ & 0.148 & $\begin{array}{l}\text { The Empty } \\
\text { Quarter }\end{array}$ & $\begin{array}{l}-67.70 * * * \\
(11.70)\end{array}$ & -0.104 & & & \\
\hline $\begin{array}{l}\text { East North } \\
\text { Central }\end{array}$ & $\begin{array}{c}-42.59^{* * * *} \\
(9.11) \\
\end{array}$ & -0.087 & El Norte & $\begin{array}{c}-7.27 \\
(17.06) \\
\end{array}$ & -0.007 & Ecotopia & $\begin{array}{l}-59.33^{* * *} \\
(11.50) \\
\end{array}$ & -0.049 & & & \\
\hline $\begin{array}{l}\text { West North } \\
\text { Central }\end{array}$ & $\begin{array}{l}-60.59^{* * * *} \\
(10.21) \\
\end{array}$ & -0.141 & Far West & $\begin{array}{l}12.34 \\
(8.16) \\
\end{array}$ & 0.024 & Breadbasket & $\begin{array}{c}-52.34 * * * * \\
(9.39) \\
\end{array}$ & -0.141 & & & \\
\hline South Atlantic & $\begin{array}{r}-10.79 \\
(9.96) \\
\end{array}$ & -0.025 & $\begin{array}{l}\text { Greater } \\
\text { Appalachia }\end{array}$ & $\begin{array}{l}73.23 * * * * \\
(6.45) \\
\end{array}$ & 0.197 & MexAmerica & $\begin{array}{l}-100.45^{* * * *} \\
(13.65) \\
\end{array}$ & -0.121 & & & \\
\hline $\begin{array}{l}\text { East South } \\
\text { Central }\end{array}$ & $\begin{array}{l}34.89^{* *} \\
(12.42)\end{array}$ & 0.066 & Left Coast & $\begin{array}{c}5.87 \\
(9.54) \\
\end{array}$ & 0.005 & The Foundry & $\begin{array}{c}-41.52^{* * * *} \\
(8.69) \\
\end{array}$ & -0.084 & & & \\
\hline $\begin{array}{l}\text { West South } \\
\text { Central }\end{array}$ & $\begin{array}{c}2.83 \\
(11.31) \\
\end{array}$ & 0.006 & Midlands & $\begin{array}{l}17.29 * * \\
(6.12) \\
\end{array}$ & 0.036 & Dixie & $\begin{array}{l}-2.31 \\
(9.58) \\
\end{array}$ & -0.007 & & & \\
\hline Mountain & $\begin{array}{l}-36.32 * * \\
(12.47) \\
\end{array}$ & -0.060 & New France & $\begin{array}{c}3.72 \\
(20.84) \\
\end{array}$ & 0.002 & The Islands & $\begin{array}{l}-186.81 * * * * \\
(25.99) \\
\end{array}$ & -0.052 & & & \\
\hline \multirow[t]{3}{*}{ Pacific } & $\begin{array}{l}-69.41^{* * * *} \\
(11.06) \\
\end{array}$ & -0.083 & New Netherlands & $\begin{array}{l}-40.05^{*} \\
(19.62) \\
\end{array}$ & -0.021 & & & & & & \\
\hline & & & $\begin{array}{l}\text { Spanish } \\
\text { Caribbean }\end{array}$ & $\begin{array}{l}-85.97 * * \\
(28.64) \\
\end{array}$ & -0.031 & & & & & & \\
\hline & & & Tidewater & $\begin{array}{c}22.19 * \\
(10.92) \\
\end{array}$ & 0.028 & & & & & & \\
\hline RUC Code $^{\mathrm{a}}$ & & & RUC Code $^{\mathrm{a}}$ & & & RUC Code $^{\mathrm{a}}$ & & & RUC Code $^{\mathrm{a}}$ & & \\
\hline 1 (ref) & 0 & 0 & 1 (ref) & 0 & 0 & 1 (ref) & 0 & 0 & 1 (ref) & 0 & 0 \\
\hline 2 & $\begin{array}{r}-10.50 \\
(6.71)\end{array}$ & -0.019 & 2 & $\begin{array}{r}-11.34 \\
(6.73)\end{array}$ & -0.020 & 2 & $\begin{array}{r}-15.02 * \\
(6.66)\end{array}$ & -0.027 & 2 & $\begin{array}{r}-10.37 \\
(6.91)\end{array}$ & -0.019 \\
\hline 3 & $\begin{array}{l}-6.25 \\
(6.99) \\
\end{array}$ & -0.012 & 3 & $\begin{array}{l}-9.34 \\
(6.92) \\
\end{array}$ & -0.017 & 3 & $\begin{array}{c}-10.42 \\
(7.04) \\
\end{array}$ & -0.019 & 3 & $\begin{array}{l}-6.09 \\
(7.19) \\
\end{array}$ & -0.011 \\
\hline 4 & $\begin{array}{l}-5.60 \\
(7.41)\end{array}$ & -0.008 & 4 & $\begin{array}{l}-3.00 \\
(7.47)\end{array}$ & -0.005 & 4 & $\begin{array}{l}-9.64 \\
(7.41)\end{array}$ & -0.015 & 4 & $\begin{array}{l}-8.68 \\
(7.57)\end{array}$ & -0.013 \\
\hline 5 & $\begin{array}{l}23.39 * \\
(10.94)\end{array}$ & 0.024 & 5 & $\begin{array}{c}15.54 \\
(10.60)\end{array}$ & 0.016 & 5 & $\begin{array}{c}12.93 \\
(10.99)\end{array}$ & 0.014 & 5 & $\begin{array}{c}16.24 \\
(11.00)\end{array}$ & 0.017 \\
\hline
\end{tabular}




\begin{tabular}{|c|c|c|c|c|c|c|c|c|c|c|c|}
\hline 6 & $\begin{array}{l}-4.77 \\
(7.07)\end{array}$ & -0.011 & 6 & $\begin{array}{l}-8.70 \\
(7.10)\end{array}$ & -0.020 & 6 & $\begin{array}{r}-11.70 \\
(7.12)\end{array}$ & -0.027 & 6 & $\begin{array}{l}-9.19 \\
(7.18)\end{array}$ & -0.021 \\
\hline 7 & $\begin{array}{c}-12.64 \\
(7.84)\end{array}$ & -0.026 & 7 & $\begin{array}{c}-13.73 \\
(7.72)\end{array}$ & -0.028 & 7 & $\begin{array}{c}-22.75 * * \\
(7.67)\end{array}$ & -0.047 & 7 & $\begin{array}{c}-19.89 * \\
(7.75)\end{array}$ & -0.041 \\
\hline 8 & $\begin{array}{l}-14.62 \\
(10.58)\end{array}$ & -0.022 & 8 & $\begin{array}{l}-16.91 \\
(10.41)\end{array}$ & -0.026 & 8 & $\begin{array}{l}-24.00 * \\
(10.47)\end{array}$ & -0.037 & 8 & $\begin{array}{l}-16.19 \\
(10.55) \\
\end{array}$ & -0.025 \\
\hline 9 & $\begin{array}{c}-8.49 \\
(10.19)\end{array}$ & -0.017 & 9 & $\begin{array}{l}-10.20 \\
(10.04)\end{array}$ & -0.020 & 9 & $\begin{array}{l}-25.33^{*} \\
(10.00)\end{array}$ & -0.050 & 9 & $\begin{array}{l}-17.62 \\
(10.05)\end{array}$ & -0.035 \\
\hline Typology $^{b}$ & & & Typology $^{\mathbf{b}}$ & & & Typology $^{b}$ & & & Typology $^{b}$ & & \\
\hline $\begin{array}{l}\text { Non-dependent } \\
\text { (ref) }\end{array}$ & 0 & 0 & $\begin{array}{l}\text { Non-dependent } \\
\text { (ref) }\end{array}$ & 0 & 0 & $\begin{array}{l}\text { Non-dependent } \\
\text { (ref) }\end{array}$ & 0 & 0 & $\begin{array}{l}\text { Non-dependent } \\
\text { (ref) }\end{array}$ & 0 & 0 \\
\hline Farming & $\begin{array}{c}-32.43 * * * \\
(8.42)\end{array}$ & -0.065 & Farming & $\begin{array}{c}-31.89 * * * \\
(8.38)\end{array}$ & -0.064 & Farming & $\begin{array}{l}-39.00 * * * \\
(8.51)\end{array}$ & -0.078 & Farming & $\begin{array}{c}-39.68 * * * * \\
(8.53)\end{array}$ & -0.079 \\
\hline Mining & $\begin{array}{l}43.03 * * * \\
(10.95)\end{array}$ & 0.050 & Mining & $\begin{array}{l}45.39 * * * \\
(10.66)\end{array}$ & 0.053 & Mining & $\begin{array}{l}50.58^{* *} \\
(10.89)\end{array}$ & 0.059 & Mining & $\begin{array}{l}51.17 * * * \\
(10.70) \\
\end{array}$ & 0.059 \\
\hline Manufacturing & $\begin{array}{c}1.68 \\
(4.77) \\
\end{array}$ & 0.004 & Manufacturing & $\begin{array}{c}5.16 \\
(4.68) \\
\end{array}$ & 0.014 & Manufacturing & $\begin{array}{c}5.27 \\
(4.73) \\
\end{array}$ & 0.014 & Manufacturing & $\begin{array}{c}5.93 \\
(4.78) \\
\end{array}$ & 0.016 \\
\hline Government & $\begin{array}{r}-13.68 \\
(6.96) \\
\end{array}$ & -0.026 & Government & $\begin{array}{l}-9.83 \\
(7.00)\end{array}$ & -0.019 & Government & $\begin{array}{l}-9.79 \\
(6.97) \\
\end{array}$ & -0.019 & Government & $\begin{array}{l}-9.30 \\
(7.09)\end{array}$ & -0.018 \\
\hline Service & $\begin{array}{l}-26.46 * * * \\
(6.54)\end{array}$ & -0.048 & Service & $\begin{array}{c}-20.30 * * \\
(6.59)\end{array}$ & -0.037 & Service & $\begin{array}{l}-26.20 * * * * \\
(6.61)\end{array}$ & -0.048 & Service & $\begin{array}{c}-25.54 * * * * \\
(6.63)\end{array}$ & -0.046 \\
\hline Medical Care & & & Medical Care & & & Medical Care & & & Medical Care & & \\
\hline $\begin{array}{l}\text { Active MDs } \\
\text { (rate) }\end{array}$ & $\begin{array}{c}3.83 * \\
(1.87) \\
\end{array}$ & 0.030 & $\begin{array}{l}\text { Active MDs } \\
\text { (rate) }\end{array}$ & $\begin{array}{c}4.82 * \\
(1.96)\end{array}$ & 0.038 & $\begin{array}{l}\text { Active MDs } \\
\text { (rate) }\end{array}$ & $\begin{array}{c}2.58 \\
(1.82) \\
\end{array}$ & 0.020 & Active MDs (rate) & $\begin{array}{c}1.80 \\
(1.76)\end{array}$ & 0.014 \\
\hline $\begin{array}{l}\text { Hospital Beds } \\
\text { (rate) }\end{array}$ & $\begin{array}{l}1.78 * * * \\
(0.47)\end{array}$ & 0.054 & $\begin{array}{l}\text { Hospital Beds } \\
\text { (rate) }\end{array}$ & $\begin{array}{l}1.68 * * * \\
(0.45)\end{array}$ & 0.051 & $\begin{array}{l}\text { Hospital Beds } \\
\text { (rate) }\end{array}$ & $\begin{array}{l}1.69 * * * \\
(0.47)\end{array}$ & 0.051 & $\begin{array}{l}\text { Hospital Beds } \\
\text { (rate) }\end{array}$ & $\begin{array}{l}1.56^{* * *} \\
(0.46)\end{array}$ & 0.047 \\
\hline $\begin{array}{l}\text { No Health Ins } \\
(\%)\end{array}$ & $\begin{array}{l}4.18 * * * \\
(0.92) \\
\end{array}$ & 0.121 & $\begin{array}{l}\text { No Health Ins } \\
(\%)\end{array}$ & $\begin{array}{l}4.23 * * * \\
(0.85) \\
\end{array}$ & 0.122 & $\begin{array}{l}\text { No Health Ins } \\
(\%)\end{array}$ & $\begin{array}{l}7.00 * * * \\
(0.81) \\
\end{array}$ & 0.203 & $\begin{array}{l}\text { No Health Ins } \\
(\%)\end{array}$ & $\begin{array}{l}5.34 * * * \\
(0.75)\end{array}$ & 0.155 \\
\hline Education & & & Education & & & Education & & & Education & & \\
\hline$<\mathrm{HS}^{\mathrm{c}}$ (ref) & 0 & 0 & $<\mathrm{HS}^{\mathrm{c}}(\mathrm{ref})$ & 0 & 0 & $<\mathrm{HS}^{\mathrm{c}}(\mathrm{ref})$ & 0 & 0 & $<\mathrm{HS}^{\mathrm{c}}(\mathrm{ref})$ & 0 & 0 \\
\hline $\begin{array}{l}\text { HS/Some } \\
\text { College }\end{array}$ & $\begin{array}{l}4.17 * * * * \\
(0.60)\end{array}$ & 0.181 & $\begin{array}{l}\text { HS/Some } \\
\text { College }\end{array}$ & $\begin{array}{l}3.05 * * * * \\
(0.57)\end{array}$ & 0.132 & $\begin{array}{l}\text { HS/Some } \\
\text { College }\end{array}$ & $\begin{array}{l}4.01 * * * \\
(0.57)\end{array}$ & 0.174 & HS/Some College & $\begin{array}{l}3.31 * * * * \\
(0.55) \\
\end{array}$ & 0.144 \\
\hline 4yr College + & $\begin{array}{c}1.11 \\
(0.69)\end{array}$ & 0.056 & 4yr College + & $\begin{array}{c}0.46 \\
(0.65)\end{array}$ & 0.023 & 4yr College + & $\begin{array}{c}1.33 * \\
(0.66)\end{array}$ & 0.068 & 4yr College + & $\begin{array}{l}1.70 * * \\
(0.64)\end{array}$ & 0.087 \\
\hline Race & & & Race & & & Race & & & Race & & \\
\hline Other (ref) & 0 & 0 & Other (ref) & 0 & 0 & Other (ref) & 0 & 0 & Other (ref) & 0 & 0 \\
\hline White & $\begin{array}{l}-2.30 * * * \\
(0.45) \\
\end{array}$ & -0.206 & White & $\begin{array}{l}-2.25 * * * \\
(0.46) \\
\end{array}$ & -0.202 & White & $\begin{array}{l}-1.92 * * * \\
(0.45) \\
\end{array}$ & -0.172 & White & $\begin{array}{l}-1.95 * * * \\
(0.46) \\
\end{array}$ & -0.175 \\
\hline Black & $\begin{array}{l}-0.57 \\
(0.47)\end{array}$ & -0.048 & Black & $\begin{array}{l}-0.33 \\
(0.50)\end{array}$ & -0.028 & Black & $\begin{array}{l}-0.63 \\
(0.47)\end{array}$ & -0.053 & Black & $\begin{array}{c}0.13 \\
(0.47)\end{array}$ & 0.011 \\
\hline Health Indicator & & & Health Indicator & & & Health Indicator & & & Health Indicator & & \\
\hline
\end{tabular}




\begin{tabular}{|c|c|c|c|c|c|c|c|c|c|c|c|}
\hline Obesity & $\begin{array}{l}6.43 * * * \\
(1.28)\end{array}$ & 0.118 & Obesity & $\begin{array}{l}4.42 * * * \\
(1.21)\end{array}$ & 0.081 & Obesity & $\begin{array}{l}5.16^{* * * *} \\
(1.28)\end{array}$ & 0.095 & Obesity & $\begin{array}{l}5.13 * * * \\
(1.24)\end{array}$ & 0.094 \\
\hline $\begin{array}{l}\text { Physical } \\
\text { Activity }\end{array}$ & $\begin{array}{l}-3.44 * * * * \\
(0.68) \\
\end{array}$ & -0.142 & $\begin{array}{l}\text { Physical } \\
\text { Activity }\end{array}$ & $\begin{array}{l}-3.69 * * * \\
(0.64) \\
\end{array}$ & -0.152 & $\begin{array}{l}\text { Physical } \\
\text { Activity }\end{array}$ & $\begin{array}{l}-4.41 * * * \\
(0.64) \\
\end{array}$ & -0.182 & Physical Activity & $\begin{array}{l}-4.67 * * * * \\
(0.60) \\
\end{array}$ & -0.192 \\
\hline Smoking & $\begin{array}{l}17.02 * * * \\
(1.02)\end{array}$ & 0.386 & Smoking & $\begin{array}{l}15.54 * * * \\
(0.97)\end{array}$ & 0.362 & Smoking & $\begin{array}{l}15.85^{* * * *} \\
(0.99)\end{array}$ & 0.360 & Smoking & $\begin{array}{c}19.87 * * * \\
(0.96)\end{array}$ & 0.451 \\
\hline Labor Force & & & Labor Force & & & Labor Force & & & Labor Force & & \\
\hline $\begin{array}{l}\text { Unemployed } \\
\text { (rate) }\end{array}$ & $\begin{array}{l}0.43^{* * * *} \\
(0.10)\end{array}$ & 0.074 & $\begin{array}{l}\text { Unemployed } \\
\text { (rate) }\end{array}$ & $\begin{array}{l}0.50 \text { **** } \\
(0.10)\end{array}$ & 0.087 & $\begin{array}{l}\text { Unemployed } \\
\text { (rate) }\end{array}$ & $\begin{array}{l}0.39 * * * \\
(0.10)\end{array}$ & 0.068 & Unemployed (rate) & $\begin{array}{l}0.29 * * \\
(0.09)\end{array}$ & 0.051 \\
\hline Inequality & & & Inequality & & & Inequality & & & Inequality & & \\
\hline $\mathrm{Gini}^{\mathrm{d}}$ & $\begin{array}{l}5.40^{* * * *} \\
(0.91) \\
\end{array}$ & 0.122 & $\operatorname{Gini}^{\mathrm{d}}$ & $\begin{array}{l}4.98 * * * \\
(0.92) \\
\end{array}$ & 0.113 & Gini $^{\mathrm{d}}$ & $\begin{array}{l}5.90 * * * \\
(0.91) \\
\end{array}$ & 0.134 & $\operatorname{Gini}^{\mathrm{d}}$ & $\begin{array}{l}6.44 * * * \\
(0.91) \\
\end{array}$ & 0.146 \\
\hline $\mathbf{N}$ & \multicolumn{2}{|c|}{3,070} & $\mathbf{N}$ & \multicolumn{2}{|c|}{3,070} & $\mathbf{N}$ & \multicolumn{2}{|c|}{3,070} & $\mathbf{N}$ & \multicolumn{2}{|c|}{3,070} \\
\hline Adj. $R^{2}$ & \multicolumn{2}{|c|}{0.6434} & Adj. $\mathbf{R}^{2}$ & \multicolumn{2}{|c|}{0.6487} & Adj. $\mathbf{R}^{2}$ & \multicolumn{2}{|c|}{0.6410} & Adj. $R^{2}$ & \multicolumn{2}{|c|}{0.6276} \\
\hline AIC & \multicolumn{2}{|c|}{37128.8} & AIC & \multicolumn{2}{|c|}{37085.03} & AIC & \multicolumn{2}{|c|}{37148.66} & AIC & \multicolumn{2}{|c|}{37254.74} \\
\hline BIC & \multicolumn{2}{|c|}{37333.8} & BIC & \multicolumn{2}{|c|}{37302.09} & BIC & \multicolumn{2}{|c|}{37347.63} & BIC & \multicolumn{2}{|c|}{37411.5} \\
\hline
\end{tabular}

Note. Coefficients with robust standard error in parentheses. ${ }^{*} \mathrm{p}<0.05, * * \mathrm{p}<0.01, * * * \mathrm{p}<0.001$

Dependent variable: Male mortality (rates) in 2010 (2008-2012)

${ }^{\mathrm{a}}=$ Rural Urban Continuum Code (2003)

${ }^{\mathrm{b}}=(2004) ;($ all other control variables are 2000 unless otherwise noted)

${ }^{\mathrm{c}}=$ Age $25+;(\%)$

${ }^{\mathrm{d}}=$ Gini Index multiplied times 100 to see increment changes 
Table 15. Model 5b: Female Mortality with All Mediators

\begin{tabular}{|c|c|c|c|c|c|c|c|c|c|c|c|}
\hline \multirow{2}{*}{ Mortality } & \multicolumn{2}{|c|}{ Census } & \multirow{2}{*}{ Mortality } & \multicolumn{2}{|c|}{ Woodard } & \multirow{2}{*}{ Mortality } & \multicolumn{2}{|c|}{ Garreau } & \multirow{2}{*}{ Mortality } & \multicolumn{2}{|c|}{ No Regions } \\
\hline & Coef & Beta & & Coef & Beta & & Coef & Beta & & Coef & Beta \\
\hline Intercept & $\begin{array}{l}405.69 * * * \\
(81.64)\end{array}$ & -- & Intercept & $\begin{array}{l}494.64 * * * \\
(82.21)\end{array}$ & -- & Intercept & $\begin{array}{l}478.89 * * * \\
(86.79)\end{array}$ & -- & Intercept & $\begin{array}{l}515.74 * * * \\
(82.42)\end{array}$ & -- \\
\hline Region & & & Region & & & Region & & & Region & & \\
\hline $\begin{array}{l}\text { New England } \\
\text { (ref) }\end{array}$ & 0 & 0 & Yankeedom (ref) & 0 & 0 & $\begin{array}{l}\text { New England } \\
\text { (ref) }\end{array}$ & 0 & 0 & -- & -- & -- \\
\hline Mid Atlantic & $\begin{array}{c}-29.39 * * * \\
(7.10)\end{array}$ & -0.053 & Deep South & $\begin{array}{l}58.19 * * * \\
(6.92)\end{array}$ & 0.180 & $\begin{array}{l}\text { The Empty } \\
\text { Quarter }\end{array}$ & $\begin{array}{c}-11.82 \\
(9.58)\end{array}$ & -0.026 & & & \\
\hline $\begin{array}{l}\text { East North } \\
\text { Central }\end{array}$ & $\begin{array}{r}-11.99 \\
(6.98) \\
\end{array}$ & -0.035 & El Norte & $\begin{array}{l}-28.15^{*} \\
(12.85) \\
\end{array}$ & -0.039 & Ecotopia & $\begin{array}{r}-13.86 \\
(9.53) \\
\end{array}$ & -0.016 & & & \\
\hline $\begin{array}{l}\text { West North } \\
\text { Central }\end{array}$ & $\begin{array}{c}-22.49 * * \\
(7.40) \\
\end{array}$ & -0.075 & Far West & $\begin{array}{l}17.92 * * \\
(6.59) \\
\end{array}$ & 0.051 & Breadbasket & $\begin{array}{r}-13.40 \\
(7.42) \\
\end{array}$ & -0.051 & & & \\
\hline South Atlantic & $\begin{array}{l}15.74^{*} \\
(7.56)\end{array}$ & 0.052 & $\begin{array}{l}\text { Greater } \\
\text { Appalachia }\end{array}$ & $\begin{array}{l}54.11 * * * \\
(4.60)\end{array}$ & 0.207 & MexAmerica & $\begin{array}{l}-62.59 * * * \\
(11.15)\end{array}$ & -0.108 & & & \\
\hline $\begin{array}{l}\text { East South } \\
\text { Central }\end{array}$ & $\begin{array}{l}44.81 * * * \\
(8.94) \\
\end{array}$ & 0.121 & Left Coast & $\begin{array}{c}6.32 \\
(7.52) \\
\end{array}$ & 0.007 & The Foundry & $\begin{array}{c}-18.10^{*} \\
(6.98) \\
\end{array}$ & -0.052 & & & \\
\hline $\begin{array}{l}\text { West South } \\
\text { Central }\end{array}$ & $\begin{array}{l}41.08 * * * * \\
(8.30)\end{array}$ & 0.123 & Midlands & $\begin{array}{l}19.23 * * * \\
(4.52) \\
\end{array}$ & 0.057 & Dixie & $\begin{array}{l}11.45 \\
(7.60) \\
\end{array}$ & 0.047 & & & \\
\hline Mountain & $\begin{array}{l}14.42 \\
(9.88)\end{array}$ & 0.034 & New France & $\begin{array}{c}22.94 \\
(16.17)\end{array}$ & 0.017 & The Islands & $\begin{array}{l}-149.43 * * * \\
(18.06)\end{array}$ & -0.060 & & & \\
\hline Pacific & $\begin{array}{r}-11.47 \\
(9.30) \\
\end{array}$ & -0.019 & New Netherlands & $\begin{array}{l}-52.84 * * * \\
(13.90)\end{array}$ & -0.039 & & & & & & \\
\hline & & & $\begin{array}{l}\text { Spanish } \\
\text { Caribbean }\end{array}$ & $\begin{array}{l}-57.85^{*} \\
(26.76) \\
\end{array}$ & -0.030 & & & & & & \\
\hline & & & Tidewater & $\begin{array}{l}14.67^{*} \\
(6.92)\end{array}$ & 0.026 & & & & & & \\
\hline RUC Code $^{\mathrm{a}}$ & & & RUC Code $^{\mathrm{a}}$ & & & RUC Code $^{\mathrm{a}}$ & & & RUC Code $^{\mathrm{a}}$ & & \\
\hline 1 (ref) & 0 & 0 & 1 (ref) & 0 & 0 & 1 (ref) & 0 & 0 & 1 (ref) & 0 & 0 \\
\hline 2 & $\begin{array}{l}-8.02 \\
(5.04)\end{array}$ & -0.021 & 2 & $\begin{array}{c}-10.94^{*} \\
(4.85)\end{array}$ & -0.028 & 2 & $\begin{array}{r}-11.95^{*} \\
(5.02)\end{array}$ & -0.031 & 2 & $\begin{array}{l}-6.89 \\
(5.19)\end{array}$ & -0.018 \\
\hline 3 & $\begin{array}{l}-7.35 \\
(5.08)\end{array}$ & -0.019 & 3 & $\begin{array}{c}-12.86 * * \\
(4.88)\end{array}$ & -0.034 & 3 & $\begin{array}{r}-12.67 * \\
(5.11)\end{array}$ & -0.034 & 3 & $\begin{array}{l}-5.28 \\
(5.13)\end{array}$ & -0.014 \\
\hline 4 & $\begin{array}{l}-8.41 \\
(5.40)\end{array}$ & -0.018 & 4 & $\begin{array}{r}-10.97 * \\
(5.37)\end{array}$ & -0.023 & 4 & $\begin{array}{r}-13.81 * \\
(5.49)\end{array}$ & -0.030 & 4 & $\begin{array}{r}-10.96 \\
(5.62)\end{array}$ & -0.023 \\
\hline 5 & $\begin{array}{l}11.27 \\
(7.00)\end{array}$ & 0.017 & 5 & $\begin{array}{c}1.75 \\
(6.89)\end{array}$ & 0.003 & 5 & $\begin{array}{l}-1.48 \\
(7.24)\end{array}$ & -0.002 & 5 & $\begin{array}{c}6.56 \\
(7.12)\end{array}$ & 0.010 \\
\hline
\end{tabular}




\begin{tabular}{|c|c|c|c|c|c|c|c|c|c|c|c|}
\hline 6 & $\begin{array}{l}-6.15 \\
(5.08)\end{array}$ & -0.020 & 6 & $\begin{array}{r}-12.11 * \\
(4.98)\end{array}$ & -0.040 & 6 & $\begin{array}{c}-14.46 * * \\
(5.12)\end{array}$ & -0.048 & 6 & $\begin{array}{l}-8.20 \\
(5.14)\end{array}$ & -0.027 \\
\hline 7 & $\begin{array}{l}-9.67 \\
(5.80)\end{array}$ & -0.028 & 7 & $\begin{array}{r}-13.99^{*} \\
(5.51)\end{array}$ & -0.041 & 7 & $\begin{array}{c}-21.06 * * * \\
(5.77)\end{array}$ & -0.062 & 7 & $\begin{array}{r}-13.65^{*} \\
(5.71)\end{array}$ & -0.040 \\
\hline 8 & $\begin{array}{c}-19.88 * * \\
(7.50)\end{array}$ & -0.043 & 8 & $\begin{array}{c}-25.28 * * \\
(7.39)\end{array}$ & -0.055 & 8 & $\begin{array}{l}-31.05^{* * * *} \\
(7.55)\end{array}$ & -0.068 & 8 & $\begin{array}{c}-20.75^{* *} \\
(7.63)\end{array}$ & -0.045 \\
\hline 9 & $\begin{array}{l}-9.00 \\
(7.26)\end{array}$ & -0.025 & 9 & $\begin{array}{r}-16.43 * \\
(6.94)\end{array}$ & -0.046 & 9 & $\begin{array}{l}-26.16 * * * \\
(7.17)\end{array}$ & -0.073 & 9 & $\begin{array}{r}-16.09 * \\
(7.07)\end{array}$ & -0.045 \\
\hline Typology $^{\mathbf{b}}$ & & & Typology $^{b}$ & & & Typology $^{b}$ & & & Typology $^{b}$ & & \\
\hline $\begin{array}{l}\text { Non-dependent } \\
\text { (ref) }\end{array}$ & 0 & 0 & $\begin{array}{l}\text { Non-dependent } \\
\text { (ref) }\end{array}$ & 0 & 0 & $\begin{array}{l}\text { Non-dependent } \\
\text { (ref) }\end{array}$ & 0 & 0 & $\begin{array}{l}\text { Non-dependent } \\
\text { (ref) }\end{array}$ & 0 & 0 \\
\hline Farming & $\begin{array}{c}-20.52 * * \\
(6.02)\end{array}$ & -0.058 & Farming & $\begin{array}{c}-25.11 * * * \\
(6.03)\end{array}$ & -0.072 & Farming & $\begin{array}{c}-28.71 * * * \\
(6.21) \\
\end{array}$ & -0.082 & Farming & $\begin{array}{c}-25.84 * * * \\
(6.16) \\
\end{array}$ & -0.074 \\
\hline Mining & $\begin{array}{l}34.49 * * * \\
(8.68)\end{array}$ & 0.057 & Mining & $\begin{array}{l}40.90 * * * \\
(8.54)\end{array}$ & 0.068 & Mining & $\begin{array}{l}41.77 * * * \\
(8.58)\end{array}$ & 0.069 & Mining & $\begin{array}{l}44.05^{* * * *} \\
(8.46)\end{array}$ & 0.073 \\
\hline Manufacturing & $\begin{array}{l}-1.05 \\
(3.46)\end{array}$ & -0.004 & Manufacturing & $\begin{array}{c}0.68 \\
(3.38)\end{array}$ & 0.003 & Manufacturing & $\begin{array}{c}1.77 \\
(3.48)\end{array}$ & 0.007 & Manufacturing & $\begin{array}{c}1.30 \\
(3.48)\end{array}$ & 0.005 \\
\hline Government & $\begin{array}{l}-4.06 \\
(4.77) \\
\end{array}$ & -0.011 & Government & $\begin{array}{c}1.09 \\
(4.71) \\
\end{array}$ & 0.003 & Government & -0.034 & -0.000 & Government & $\begin{array}{l}-0.54 \\
(4.81) \\
\end{array}$ & -0.001 \\
\hline Service & $\begin{array}{c}-21.60 * * * \\
(4.89)\end{array}$ & -0.056 & Service & $\begin{array}{c}-19.03 * * * \\
(4.88)\end{array}$ & -0.049 & Service & $\begin{array}{c}-21.37 * * * \\
(4.99)\end{array}$ & -0.055 & Service & $\begin{array}{c}-23.13^{* * * *} \\
(5.10)\end{array}$ & -0.060 \\
\hline Medical Care & & & Medical Care & & & Medical Care & & & Medical Care & & \\
\hline $\begin{array}{l}\text { Active MDs } \\
\text { (rate) }\end{array}$ & $\begin{array}{c}0.78 \\
(1.12)\end{array}$ & 0.009 & $\begin{array}{l}\text { Active MDs } \\
\text { (rate) }\end{array}$ & $\begin{array}{c}1.52 \\
(1.11)\end{array}$ & 0.017 & $\begin{array}{l}\text { Active MDs } \\
\text { (rate) }\end{array}$ & $\begin{array}{l}-0.14 \\
(1.13)\end{array}$ & -0.002 & Active MDs (rate) & $\begin{array}{l}-1.19 \\
(1.14)\end{array}$ & -0.013 \\
\hline $\begin{array}{l}\text { Hospital Beds } \\
\text { (rate) }\end{array}$ & $\begin{array}{l}0.96^{* *} \\
(0.36)\end{array}$ & 0.041 & $\begin{array}{l}\text { Hospital Beds } \\
\text { (rate) }\end{array}$ & $\begin{array}{l}0.82^{*} \\
(0.34) \\
\end{array}$ & 0.035 & $\begin{array}{l}\text { Hospital Beds } \\
\text { (rate) }\end{array}$ & $\begin{array}{c}0.74 * \\
(0.36) \\
\end{array}$ & 0.032 & $\begin{array}{l}\text { Hospital Beds } \\
\text { (rate) }\end{array}$ & $\begin{array}{c}0.74^{*} \\
(0.35) \\
\end{array}$ & 0.032 \\
\hline $\begin{array}{l}\text { No Health Ins } \\
(\%)\end{array}$ & $\begin{array}{c}0.46 \\
(0.73)\end{array}$ & 0.019 & $\begin{array}{l}\text { No Health Ins } \\
(\%)\end{array}$ & $\begin{array}{l}2.24 * * \\
(0.65)\end{array}$ & 0.092 & $\begin{array}{l}\text { No Health Ins } \\
(\%)\end{array}$ & $\begin{array}{l}3.61 * * * \\
(0.64)\end{array}$ & 0.149 & $\begin{array}{l}\text { No Health Ins } \\
(\%)\end{array}$ & $\begin{array}{l}2.74 * * * * \\
(0.60)\end{array}$ & 0.113 \\
\hline Education & & & Education & & & Education & & & Education & & \\
\hline$<\mathrm{HS}^{\mathrm{c}}$ (ref) & 0 & 0 & $<\mathrm{HS}^{\mathrm{c}}$ (ref) & 0 & 0 & $<\mathrm{HS}^{\mathrm{c}}$ (ref) & 0 & 0 & $<\mathrm{HS}^{\mathrm{c}}$ (ref) & 0 & 0 \\
\hline $\begin{array}{l}\text { HS/Some } \\
\text { College }\end{array}$ & $\begin{array}{l}1.87 * * \\
(0.56)\end{array}$ & 0.107 & $\begin{array}{l}\text { HS/Some } \\
\text { College }\end{array}$ & $\begin{array}{c}0.79 \\
(0.53)\end{array}$ & 0.045 & $\begin{array}{l}\text { HS/Some } \\
\text { College }\end{array}$ & $\begin{array}{l}1.52 * * \\
(0.55)\end{array}$ & 0.087 & HS/Some College & $\begin{array}{c}1.19^{*} \\
(0.53)\end{array}$ & 0.068 \\
\hline 4yr College + & $\begin{array}{c}0.75 \\
(0.59) \\
\end{array}$ & 0.045 & 4yr College + & $\begin{array}{l}-0.17 \\
(0.60)\end{array}$ & -0.010 & 4yr College + & $\begin{array}{l}0.32 \\
(0.61)\end{array}$ & 0.019 & 4yr College + & $\begin{array}{c}0.57 \\
(0.59)\end{array}$ & 0.034 \\
\hline Race & & & Race & & & Race & & & Race & & \\
\hline Other (ref) & 0 & 0 & Other (ref) & 0 & 0 & Other (ref) & 0 & 0 & Other (ref) & 0 & 0 \\
\hline White & $\begin{array}{l}-2.06 * * * \\
(0.49)\end{array}$ & -0.274 & White & $\begin{array}{l}-1.98 * * * \\
(0.49)\end{array}$ & -0.264 & White & $\begin{array}{l}-1.78 * * * \\
(0.49)\end{array}$ & -0.237 & White & $\begin{array}{l}-1.87 * * * \\
(0.49)\end{array}$ & -0.250 \\
\hline Black & $\begin{array}{l}-1.45^{* *} \\
(0.54)\end{array}$ & -0.182 & Black & $\begin{array}{l}-1.43 * * \\
(0.55)\end{array}$ & -0.179 & Black & $\begin{array}{l}-1.49 * * \\
(0.54)\end{array}$ & -0.188 & Black & $\begin{array}{l}-0.84 \\
(0.52)\end{array}$ & -0.106 \\
\hline Health Indicator & & & Health Indicator & & & Health Indicator & & & & & \\
\hline
\end{tabular}




\begin{tabular}{|c|c|c|c|c|c|c|c|c|c|c|c|}
\hline Obesity & $\begin{array}{l}3.89 * * * \\
(0.81)\end{array}$ & 0.164 & Obesity & $\begin{array}{l}2.64 * * \\
(0.81)\end{array}$ & 0.111 & Obesity & $\begin{array}{l}2.32 * * \\
(0.83)\end{array}$ & 0.098 & Obesity & $\begin{array}{c}1.35 \\
(0.82)\end{array}$ & 0.057 \\
\hline $\begin{array}{l}\text { Physical } \\
\text { Activity }\end{array}$ & $\begin{array}{l}-2.94 * * * * \\
(0.49) \\
\end{array}$ & -0.196 & $\begin{array}{l}\text { Physical } \\
\text { Activity }\end{array}$ & $\begin{array}{l}-2.68 * * * * \\
(0.48) \\
\end{array}$ & -0.179 & $\begin{array}{l}\text { Physical } \\
\text { Activity }\end{array}$ & $\begin{array}{l}-3.83 * * * * \\
(0.47) \\
\end{array}$ & -0.255 & Physical Activity & $\begin{array}{l}-4.32 * * * * \\
(0.42) \\
\end{array}$ & -0.288 \\
\hline Smoking & $\begin{array}{l}12.18 * * * \\
(0.72)\end{array}$ & 0.385 & Smoking & $\begin{array}{l}10.60 * * * \\
(0.73)\end{array}$ & 0.335 & Smoking & $\begin{array}{l}10.44 * * * \\
(0.78)\end{array}$ & 0.330 & Smoking & $\begin{array}{c}12.73 * * * * \\
(0.72)\end{array}$ & 0.402 \\
\hline Labor Force & & & Labor Force & & & Labor Force & & & Labor Force & & \\
\hline $\begin{array}{l}\text { Unemployed } \\
\text { (rate) }\end{array}$ & $\begin{array}{l}0.31 * * \\
(0.10)\end{array}$ & 0.074 & $\begin{array}{l}\text { Unemployed } \\
\text { (rate) }\end{array}$ & $\begin{array}{l}0.31 * * \\
(0.09)\end{array}$ & 0.073 & $\begin{array}{l}\text { Unemployed } \\
\text { (rate) }\end{array}$ & $\begin{array}{l}0.28 * * \\
(0.10)\end{array}$ & 0.066 & $\begin{array}{l}\text { Unemployed } \\
\text { (rate) }\end{array}$ & $\begin{array}{l}0.27 * * \\
(0.09) \\
\end{array}$ & 0.064 \\
\hline Inequality & & & Inequality & & & Inequality & & & Inequality & & \\
\hline Gini $^{\mathrm{d}}$ & $\begin{array}{l}2.28 * * \\
(0.70) \\
\end{array}$ & 0.074 & Gini $^{\mathrm{d}}$ & $\begin{array}{l}2.28 * * \\
(0.70) \\
\end{array}$ & 0.073 & $\operatorname{Gini}^{\mathrm{d}}$ & $\begin{array}{l}3.06^{* * * *} \\
(0.69) \\
\end{array}$ & 0.099 & $\operatorname{Gini}^{\mathrm{d}}$ & $\begin{array}{l}2.84 * * * * \\
(0.70) \\
\end{array}$ & 0.091 \\
\hline $\mathbf{N}$ & \multicolumn{2}{|c|}{3,070} & $\mathbf{N}$ & \multicolumn{2}{|c|}{3,070} & $\mathbf{N}$ & \multicolumn{2}{|c|}{3,070} & $\mathbf{N}$ & \multicolumn{2}{|c|}{3,070} \\
\hline Adj. $R^{2}$ & \multicolumn{2}{|c|}{0.6174} & Adj. $\mathbf{R}^{2}$ & \multicolumn{2}{|c|}{0.6229} & Adj. $\mathbf{R}^{2}$ & \multicolumn{2}{|c|}{0.6089} & Adj. $R^{2}$ & \multicolumn{2}{|c|}{0.5954} \\
\hline AIC & \multicolumn{2}{|c|}{35176.55} & AIC & \multicolumn{2}{|c|}{35134.34} & AIC & \multicolumn{2}{|c|}{35243.31} & AIC & \multicolumn{2}{|c|}{35340.98} \\
\hline BIC & \multicolumn{2}{|c|}{35381.55} & BIC & \multicolumn{2}{|c|}{35351.4} & BIC & \multicolumn{2}{|c|}{35442.28} & BIC & \multicolumn{2}{|c|}{35497.75} \\
\hline
\end{tabular}

Note. Coefficients with robust standard error in parentheses. ${ }^{*} \mathrm{p}<0.05,{ }^{*} \mathrm{*} \mathrm{p} \leq 0.01,{ }^{*} * \mathrm{p} \leq 0.001$

Dependent variable: Female mortality (rates) in 2010 (2008-2012)

${ }^{\mathrm{a}}=$ Rural Urban Continuum Code (2003)

${ }^{\mathrm{b}}=(2004) ;($ all other control variables are 2000 unless otherwise noted $)$

${ }^{\mathrm{c}}=$ Age $25+;(\%)$

${ }^{\mathrm{d}}=$ Gini Index multiplied times 100 to see increment changes 
Table 16. Male Mortality Models: Census

\begin{tabular}{|c|c|c|c|c|c|c|c|c|c|c|}
\hline \multirow{2}{*}{ Census } & \multicolumn{2}{|c|}{ Model 1a } & \multicolumn{2}{|c|}{ Model 2a } & \multicolumn{2}{|c|}{ Model 3a } & \multicolumn{2}{|c|}{ Model 4a } & \multicolumn{2}{|c|}{ Model 5a } \\
\hline & Coef & Beta & Coef & Beta & Coef & Beta & Coef & Beta & Coef & Beta \\
\hline Intercept & $\begin{array}{c}848.79 * * * \\
(9.20)\end{array}$ & -- & $\begin{array}{l}370.02 * * * * \\
(38.06)\end{array}$ & -- & $\begin{array}{l}425.54 * * * \\
(90.58)\end{array}$ & -- & $\begin{array}{l}893.61 * * * \\
(98.87)\end{array}$ & -- & $\begin{array}{l}224.58^{*} \\
(99.01)\end{array}$ & -- \\
\hline \multicolumn{11}{|l|}{ Region } \\
\hline New England (ref) & 0 & 0 & 0 & 0 & 0 & 0 & 0 & 0 & 0 & 0 \\
\hline Mid Atlantic & $\begin{array}{l}45.60 * * * \\
(12.10)\end{array}$ & 0.058 & $\begin{array}{c}25.20^{*} \\
(12.29)\end{array}$ & 0.032 & $\begin{array}{c}-40.18 * * * \\
(9.54)\end{array}$ & -0.051 & $\begin{array}{l}-64.15^{* * *} \\
(10.59)\end{array}$ & -0.081 & $\begin{array}{c}-43.41 * * * \\
(9.73)\end{array}$ & -0.055 \\
\hline East North Central & $\begin{array}{l}97.92 * * * \\
(10.59)\end{array}$ & 0.201 & $\begin{array}{l}58.15 * * * \\
(10.94)\end{array}$ & 0.119 & $\begin{array}{c}-42.22 * * * \\
(9.07)\end{array}$ & -0.087 & $\begin{array}{c}-36.48 * * * \\
(9.72)\end{array}$ & -0.075 & $\begin{array}{c}-42.59 * * * \\
(9.11)\end{array}$ & -0.087 \\
\hline West North Central & $\begin{array}{l}59.83 * * * \\
(11.02) \\
\end{array}$ & 0.139 & $\begin{array}{c}16.15 \\
(11.93) \\
\end{array}$ & 0.038 & $\begin{array}{l}-55.67 * * * \\
(10.10) \\
\end{array}$ & -0.130 & $\begin{array}{l}-78.32 * * * \\
(10.89) \\
\end{array}$ & -0.183 & $\begin{array}{l}-60.59 * * * \\
(10.21) \\
\end{array}$ & -0.141 \\
\hline South Atlantic & $\begin{array}{l}174.85^{* * *} \\
(11.37)\end{array}$ & 0.403 & $\begin{array}{l}106.07 * * * \\
(11.54)\end{array}$ & 0.244 & $\begin{array}{l}-6.16 \\
(9.92)\end{array}$ & -0.014 & $\begin{array}{c}-5.81 \\
(10.48)\end{array}$ & -0.013 & $\begin{array}{c}-10.79 \\
(9.96)\end{array}$ & -0.025 \\
\hline East South Central & $\begin{array}{l}317.43^{* * *} \\
(11.97)\end{array}$ & 0.602 & $\begin{array}{l}205.48^{* * *} \\
(12.66)\end{array}$ & 0.390 & $\begin{array}{l}41.71 * * \\
(12.57)\end{array}$ & 0.079 & $\begin{array}{l}66.37 * * * \\
(12.67)\end{array}$ & 0.126 & $\begin{array}{l}34.89 * * \\
(12.42)\end{array}$ & 0.066 \\
\hline West South Central & $\begin{array}{l}194.80 * * * \\
(11.61)\end{array}$ & 0.409 & $\begin{array}{l}89.17 \text { *** } \\
(12.88)\end{array}$ & 0.187 & $\begin{array}{c}16.86 \\
(11.23)\end{array}$ & 0.035 & $\begin{array}{l}-12.66 \\
(11.96) \\
\end{array}$ & -0.027 & $\begin{array}{c}2.83 \\
(11.31) \\
\end{array}$ & 0.006 \\
\hline Mountain & $\begin{array}{c}23.37 \\
(13.21)\end{array}$ & 0.039 & $\begin{array}{l}-24.41 \\
(13.63)\end{array}$ & -0.041 & $\begin{array}{l}-32.56^{* * *} \\
(12.17)\end{array}$ & -0.054 & $\begin{array}{l}-51.07 * * * \\
(13.23)\end{array}$ & -0.085 & $\begin{array}{l}-36.32 * * \\
(12.47)\end{array}$ & -0.060 \\
\hline Pacific & $\begin{array}{l}-10.12 \\
(12.89)\end{array}$ & -0.012 & $\begin{array}{l}-53.53^{* * *} \\
(13.09)\end{array}$ & -0.064 & $\begin{array}{l}-66.46^{* * * *} \\
(11.02)\end{array}$ & -0.079 & $\begin{array}{l}-87.94 * * * \\
(11.98)\end{array}$ & -0.105 & $\begin{array}{l}-69.41 * * * \\
(11.06)\end{array}$ & -0.083 \\
\hline \multicolumn{11}{|l|}{ RUC Code $^{a}$} \\
\hline 1 (ref) & -- & -- & 0 & 0 & -- & -- & 0 & 0 & 0 & 0 \\
\hline 2 & -- & -- & $\begin{array}{c}8.72 \\
(8.80)\end{array}$ & 0.016 & -- & -- & $\begin{array}{l}-7.76 \\
(6.94)\end{array}$ & -0.014 & $\begin{array}{r}-10.50 \\
(6.71)\end{array}$ & -0.019 \\
\hline 3 & -- & -- & $\begin{array}{l}13.09 \\
(8.96)\end{array}$ & 0.024 & -- & -- & $\begin{array}{r}-11.15 \\
(7.31)\end{array}$ & -0.021 & $\begin{array}{l}-6.25 \\
(6.99)\end{array}$ & -0.012 \\
\hline 4 & -- & -- & $\begin{array}{l}34.51 * * * \\
(9.73)\end{array}$ & 0.052 & -- & -- & $\begin{array}{l}-1.02 \\
(7.95)\end{array}$ & -0.002 & $\begin{array}{l}-5.60 \\
(7.41)\end{array}$ & -0.008 \\
\hline 5 & -- & -- & $\begin{array}{l}\text { 49.24** } \\
(14.71)\end{array}$ & 0.052 & -- & -- & $\begin{array}{c}25.77 * \\
(11.74)\end{array}$ & 0.027 & $\begin{array}{c}23.39^{*} \\
(10.94)\end{array}$ & 0.024 \\
\hline 6 & -- & -- & $\begin{array}{l}41.29 * * * \\
(8.96)\end{array}$ & 0.097 & -- & -- & $\begin{array}{l}-9.23 \\
(7.33)\end{array}$ & -0.022 & $\begin{array}{l}-4.77 \\
(7.07)\end{array}$ & -0.011 \\
\hline
\end{tabular}




\begin{tabular}{|c|c|c|c|c|c|c|c|c|c|c|}
\hline 7 & -- & -- & $\begin{array}{l}28.74 * * \\
(10.05) \\
\end{array}$ & 0.059 & -- & -- & $\begin{array}{c}-15.41 \\
(8.27) \\
\end{array}$ & -0.032 & $\begin{array}{r}-12.64 \\
(7.84) \\
\end{array}$ & -0.026 \\
\hline 8 & -- & -- & $\begin{array}{c}7.67 \\
(12.87) \\
\end{array}$ & 0.012 & -- & -- & $\begin{array}{l}-36.32 * * \\
(10.78) \\
\end{array}$ & -0.056 & $\begin{array}{l}-14.62 \\
(10.58) \\
\end{array}$ & -0.022 \\
\hline 9 & -- & -- & $\begin{array}{c}11.83 \\
(12.28)\end{array}$ & 0.023 & -- & -- & $\begin{array}{l}-29.25 * * \\
(10.45)\end{array}$ & -0.058 & $\begin{array}{c}-8.49 \\
(10.19)\end{array}$ & -0.017 \\
\hline \multicolumn{11}{|l|}{ Typology $^{\mathbf{b}}$} \\
\hline $\begin{array}{l}\text { Non-dependent } \\
\text { (ref) }\end{array}$ & -- & -- & 0 & 0 & -- & -- & 0 & 0 & 0 & 0 \\
\hline Farming & -- & -- & $\begin{array}{c}-49.33^{* * * *} \\
(9.34) \\
\end{array}$ & -0.099 & -- & -- & $\begin{array}{l}-60.50 * * * \\
(8.69) \\
\end{array}$ & -0.121 & $\begin{array}{c}-32.43^{* * * *} \\
(8.42)\end{array}$ & -0.065 \\
\hline Mining & -- & -- & $\begin{array}{l}63.15^{* * * *} \\
(14.05) \\
\end{array}$ & 0.073 & -- & -- & $\begin{array}{l}46.83^{* * * *} \\
(11.91) \\
\end{array}$ & 0.054 & $\begin{array}{l}43.03^{* * * *} \\
(10.95)\end{array}$ & 0.050 \\
\hline Manufacturing & -- & -- & $\begin{array}{c}8.16 \\
(5.69)\end{array}$ & 0.022 & -- & -- & $\begin{array}{c}5.66 \\
(4.90)\end{array}$ & 0.015 & $\begin{array}{c}1.68 \\
(4.77)\end{array}$ & 0.004 \\
\hline Government & -- & -- & $\begin{array}{c}-27.33^{* *} \\
(9.25) \\
\end{array}$ & -0.052 & -- & -- & $\begin{array}{l}-9.22 \\
(7.30) \\
\end{array}$ & -0.018 & $\begin{array}{r}-13.68 \\
(6.96) \\
\end{array}$ & -0.026 \\
\hline Service & -- & -- & $\begin{array}{c}-79.27 * * * \\
(9.44)\end{array}$ & -0.144 & -- & -- & $\begin{array}{r}-17.22 * \\
(6.93) \\
\end{array}$ & -0.031 & $\begin{array}{c}-26.46^{* * * *} \\
(6.54)\end{array}$ & -0.048 \\
\hline \multicolumn{11}{|l|}{ Medical Care } \\
\hline $\begin{array}{l}\text { Active MDs } \\
\text { (rate) }\end{array}$ & -- & -- & $\begin{array}{c}-20.72 * * * \\
(3.00)\end{array}$ & -0.163 & -- & -- & $\begin{array}{l}11.15^{* * * *} \\
(2.36) \\
\end{array}$ & 0.088 & $\begin{array}{c}3.83^{*} \\
(1.87) \\
\end{array}$ & 0.030 \\
\hline $\begin{array}{l}\text { Hospital Beds } \\
\text { (rate) }\end{array}$ & -- & -- & $\begin{array}{c}2.29 * * \\
(0.695) \\
\end{array}$ & 0.069 & -- & -- & $\begin{array}{l}1.76 * * \\
(0.51) \\
\end{array}$ & 0.053 & $\begin{array}{l}1.78 * * * * \\
(0.47) \\
\end{array}$ & 0.054 \\
\hline $\begin{array}{l}\text { No Health Ins } \\
(\%)\end{array}$ & -- & -- & -- & -- & $\begin{array}{c}4.41^{* * * *} \\
(0.86) \\
\end{array}$ & 0.128 & $\begin{array}{c}1.55 \\
(1.00) \\
\end{array}$ & 0.045 & $\begin{array}{l}4.18 * * * * \\
(0.92) \\
\end{array}$ & 0.121 \\
\hline \multicolumn{11}{|l|}{ Education } \\
\hline$<\mathrm{HS}^{\mathrm{a}}(\mathrm{ref})$ & -- & -- & -- & -- & 0 & 0 & 0 & 0 & 0 & 0 \\
\hline HS/Some College & -- & -- & -- & -- & $\begin{array}{l}3.34 * * * \\
(0.61) \\
\end{array}$ & 0.145 & $\begin{array}{l}4.08 * * * * \\
(0.66)\end{array}$ & 0.177 & $\begin{array}{l}4.17 * * * * \\
(0.60)\end{array}$ & 0.181 \\
\hline 4yr College + & -- & -- & -- & -- & $\begin{array}{l}1.75 * * \\
(0.67) \\
\end{array}$ & 0.089 & $\begin{array}{l}-3.84 * * * \\
(0.65) \\
\end{array}$ & -0.196 & $\begin{array}{c}1.11 \\
(0.69) \\
\end{array}$ & 0.056 \\
\hline \multicolumn{11}{|l|}{ Race } \\
\hline Other (ref) & -- & -- & -- & -- & 0 & 0 & 0 & 0 & 0 & 0 \\
\hline White & -- & -- & -- & -- & $\begin{array}{l}-1.93 * * * \\
(0.43) \\
\end{array}$ & -0.173 & $\begin{array}{l}-3.69 * * * \\
(0.51) \\
\end{array}$ & -0.331 & $\begin{array}{l}-2.30^{* * * *} \\
(0.45) \\
\end{array}$ & -0.206 \\
\hline Black & -- & -- & -- & -- & $\begin{array}{c}0.17 \\
(0.45) \\
\end{array}$ & 0.014 & $\begin{array}{l}-2.46 * * * * \\
(0.52) \\
\end{array}$ & -0.207 & $\begin{array}{l}-0.57 \\
(0.47) \\
\end{array}$ & -0.048 \\
\hline \multicolumn{11}{|l|}{ Health Indicator } \\
\hline Obesity & -- & -- & -- & -- & $\begin{array}{l}5.55^{* * * *} \\
(1.23) \\
\end{array}$ & 0.102 & $\begin{array}{l}9.07 * * * \\
(1.33) \\
\end{array}$ & 0.167 & $\begin{array}{l}6.43 * * * \\
(1.28) \\
\end{array}$ & 0.118 \\
\hline
\end{tabular}




\begin{tabular}{|c|c|c|c|c|c|c|c|c|c|c|}
\hline Physical Activity & -- & -- & -- & -- & $\begin{array}{l}-3.72 * * * \\
(0.68)\end{array}$ & -0.153 & $\begin{array}{l}-5.80 * * * \\
(0.71)\end{array}$ & -0.239 & $\begin{array}{l}-3.44 * * * \\
(0.68)\end{array}$ & -0.142 \\
\hline Smoking & -- & -- & -- & -- & $\begin{array}{l}18.95 * * * \\
(0.97)\end{array}$ & 0.430 & -- & -- & $\begin{array}{l}17.02 * * * \\
(1.02)\end{array}$ & 0.386 \\
\hline \multicolumn{11}{|l|}{ Labor Force } \\
\hline $\begin{array}{l}\text { Unemployed } \\
\text { (rate) }\end{array}$ & -- & -- & -- & -- & $\begin{array}{l}0.74 * * * \\
(0.10)\end{array}$ & 0.128 & -- & -- & $\begin{array}{l}0.43^{* * *} \\
(0.10)\end{array}$ & 0.074 \\
\hline \multicolumn{11}{|l|}{ Inequality } \\
\hline Gini $^{\mathrm{d}}$ & -- & -- & $\begin{array}{l}12.68 * * * \\
(0.93)\end{array}$ & 0.287 & -- & -- & $\begin{array}{l}6.99 * * * * \\
(0.93)\end{array}$ & 0.158 & $\begin{array}{l}5.40 * * * \\
(0.91)\end{array}$ & 0.122 \\
\hline $\mathbf{N}$ & \multicolumn{2}{|c|}{3,070} & \multicolumn{2}{|c|}{3,070} & \multicolumn{2}{|c|}{3,070} & \multicolumn{2}{|c|}{3,070} & \multicolumn{2}{|c|}{3,070} \\
\hline Adj. R $^{2}$ & \multicolumn{2}{|c|}{0.3033} & \multicolumn{2}{|c|}{0.4305} & \multicolumn{2}{|c|}{0.6269} & \multicolumn{2}{|c|}{0.6022} & \multicolumn{2}{|c|}{0.6434} \\
\hline AIC & \multicolumn{2}{|c|}{39160.44} & \multicolumn{2}{|c|}{38557.48} & \multicolumn{2}{|c|}{37252.57} & \multicolumn{2}{|c|}{37463.17} & \multicolumn{2}{|c|}{37128.8} \\
\hline BIC & \multicolumn{2}{|c|}{39214.7} & \multicolumn{2}{|c|}{38708.22} & \multicolumn{2}{|c|}{37361.1} & \multicolumn{2}{|c|}{37656.11} & \multicolumn{2}{|c|}{37333.8} \\
\hline
\end{tabular}

Note. Coefficients with robust standard error in parentheses. $* \mathrm{p}<0.05, * * \mathrm{p}<0.01, * * * \mathrm{p}<0.001$

Dependent variable: Female mortality (rates) in 2010 (2008-2012)

${ }^{\mathrm{a}}=$ Rural Urban Continuum Code (2003)

${ }^{\mathrm{b}}=(2004) ;($ all other control variables are 2000 unless otherwise noted)

${ }^{\mathrm{c}}=$ Age $25+;(\%)$

${ }^{\mathrm{d}}=$ Gini Index multiplied times 100 to see increment changes 
Table 17. Female Mortality Models: Census

\begin{tabular}{|c|c|c|c|c|c|c|c|c|c|c|}
\hline \multirow{2}{*}{ Census } & \multicolumn{2}{|c|}{ Model 1a } & \multicolumn{2}{|c|}{ Model 2a } & \multicolumn{2}{|c|}{ Model 3a } & \multicolumn{2}{|c|}{ Model 4a } & \multicolumn{2}{|c|}{ Model 5a } \\
\hline & Coef & Beta & Coef & Beta & Coef & Beta & Coef & Beta & Coef & Beta \\
\hline Intercept & $\begin{array}{c}605.80 * * * \\
(6.15)\end{array}$ & -- & $\begin{array}{l}348.73 * * * * \\
(29.97)\end{array}$ & -- & $\begin{array}{l}498.94 * * * \\
(77.51)\end{array}$ & -- & $\begin{array}{l}849.54 * * * \\
(87.54)\end{array}$ & -- & $\begin{array}{l}405.69^{* * * *} \\
(81.64)\end{array}$ & -- \\
\hline \multicolumn{11}{|l|}{ Region } \\
\hline New England (ref) & 0 & 0 & 0 & 0 & 0 & 0 & 0 & 0 & 0 & 0 \\
\hline Mid Atlantic & $\begin{array}{l}35.40 * * * \\
(7.96)\end{array}$ & 0.064 & $\begin{array}{l}20.57 * \\
(8.07)\end{array}$ & 0.037 & $\begin{array}{c}-25.02 * * * \\
(6.84)\end{array}$ & -0.045 & $\begin{array}{c}-44.62 * * \\
(7.67)\end{array}$ & -0.080 & $\begin{array}{c}-29.39 * * * \\
(7.10)\end{array}$ & -0.053 \\
\hline East North Central & $\begin{array}{l}75.18 * * * \\
(7.22)\end{array}$ & 0.219 & $\begin{array}{l}45.05 * * * \\
(7.60)\end{array}$ & 0.132 & $\begin{array}{l}-6.11 \\
(6.81)\end{array}$ & -0.018 & $\begin{array}{c}-26.66^{* * * *} \\
(7.26)\end{array}$ & -0.078 & $\begin{array}{r}-11.99 \\
(6.98)\end{array}$ & -0.035 \\
\hline West North Central & $\begin{array}{l}34.04 * * * \\
(7.82)\end{array}$ & 0.113 & $\begin{array}{c}5.71 \\
(8.57) \\
\end{array}$ & 0.019 & $\begin{array}{c}-15.61 * \\
(7.23) \\
\end{array}$ & -0.052 & $\begin{array}{c}-56.06^{* * *} \\
(7.73) \\
\end{array}$ & -0.186 & $\begin{array}{c}-22.49^{* *} \\
(7.40) \\
\end{array}$ & -0.075 \\
\hline South Atlantic & $\begin{array}{c}126.94 * * * \\
(7.56)\end{array}$ & 0.416 & $\begin{array}{l}82.05 * * * \\
(7.95)\end{array}$ & 0.269 & $\begin{array}{l}20.90 * * \\
(7.36)\end{array}$ & 0.069 & $\begin{array}{c}1.05 \\
(7.84)\end{array}$ & 0.003 & $\begin{array}{l}15.74 * \\
(7.56)\end{array}$ & 0.052 \\
\hline East South Central & $\begin{array}{c}218.15^{* * * *} \\
(7.95)\end{array}$ & 0.589 & $\begin{array}{c}147.35^{* * * *} \\
(8.99)\end{array}$ & 0.398 & $\begin{array}{l}50.17 * * * \\
(8.86)\end{array}$ & 0.135 & $\begin{array}{l}35.67 * * * \\
(9.37)\end{array}$ & 0.096 & $\begin{array}{l}44.81 \text { *** } \\
(8.94)\end{array}$ & 0.121 \\
\hline West South Central & $\begin{array}{c}151.54 * * * \\
(7.92)\end{array}$ & 0.453 & $\begin{array}{l}83.53 * * * \\
(9.07)\end{array}$ & 0.250 & $\begin{array}{l}53.42 * * * \\
(8.14)\end{array}$ & 0.160 & $\begin{array}{l}10.22 \\
(8.66)\end{array}$ & 0.031 & $\begin{array}{l}41.08 * * * \\
(8.30)\end{array}$ & 0.123 \\
\hline Mountain & $\begin{array}{l}37.05 * * * \\
(8.84)\end{array}$ & 0.088 & $\begin{array}{c}3.98 \\
(9.12)\end{array}$ & 0.009 & $\begin{array}{l}25.76 * * \\
(9.78)\end{array}$ & 0.061 & $\begin{array}{c}-8.92 \\
(10.04)\end{array}$ & -0.021 & $\begin{array}{l}14.42 \\
(9.88)\end{array}$ & 0.034 \\
\hline Pacific & $\begin{array}{c}9.32 \\
(9.31)\end{array}$ & 0.016 & $\begin{array}{r}-19.83^{*} \\
(9.40)\end{array}$ & -0.034 & $\begin{array}{l}-2.76 \\
(9.06)\end{array}$ & -0.005 & $\begin{array}{c}-39.67 * * * \\
(9.72)\end{array}$ & -0.067 & $\begin{array}{r}-11.47 \\
(9.30)\end{array}$ & -0.019 \\
\hline \multicolumn{11}{|l|}{ RUC Code $^{a}$} \\
\hline 1 (ref) & -- & -- & 0 & 0 & -- & -- & 0 & 0 & 0 & 0 \\
\hline 2 & -- & -- & $\begin{array}{l}1.91 \\
(6.10)\end{array}$ & 0.005 & -- & -- & $\begin{array}{l}-9.08 \\
(5.29)\end{array}$ & -0.023 & $\begin{array}{l}-8.02 \\
(5.04)\end{array}$ & -0.021 \\
\hline 3 & -- & -- & $\begin{array}{c}4.01 \\
(6.30)\end{array}$ & 0.011 & -- & -- & $\begin{array}{l}-9.00 \\
(5.51)\end{array}$ & -0.024 & $\begin{array}{l}-7.35 \\
(5.08)\end{array}$ & -0.019 \\
\hline 4 & -- & -- & $\begin{array}{c}14.37 * \\
(6.77)\end{array}$ & 0.031 & -- & -- & $\begin{array}{l}-4.97 \\
(6.00)\end{array}$ & -0.011 & $\begin{array}{l}-8.41 \\
(5.40)\end{array}$ & -0.018 \\
\hline 5 & -- & -- & $\begin{array}{l}27.72 * * \\
(10.17)\end{array}$ & 0.041 & -- & -- & $\begin{array}{l}17.27 * \\
(7.95) \\
\end{array}$ & 0.026 & $\begin{array}{l}11.27 \\
(7.00) \\
\end{array}$ & 0.017 \\
\hline 6 & -- & -- & $\begin{array}{l}20.46 * * * \\
(6.33)\end{array}$ & 0.068 & -- & -- & $\begin{array}{l}-6.20 \\
(5.53)\end{array}$ & -0.021 & $\begin{array}{l}-6.15 \\
(5.08)\end{array}$ & -0.020 \\
\hline
\end{tabular}




\begin{tabular}{|c|c|c|c|c|c|c|c|c|c|c|}
\hline 7 & -- & -- & $\begin{array}{l}14.55^{*} \\
(7.20)\end{array}$ & 0.043 & -- & -- & $\begin{array}{l}-6.04 \\
(6.44)\end{array}$ & -0.018 & $\begin{array}{l}-9.67 \\
(5.80)\end{array}$ & -0.028 \\
\hline 8 & -- & -- & $\begin{array}{l}-6.95 \\
(9.42)\end{array}$ & -0.015 & -- & -- & $\begin{array}{c}-25.75 * * \\
(7.80)\end{array}$ & -0.056 & $\begin{array}{c}-19.88 * * \\
(7.50)\end{array}$ & -0.043 \\
\hline 9 & -- & -- & $\begin{array}{c}1.84 \\
(8.78)\end{array}$ & 0.005 & -- & -- & $\begin{array}{c}-11.92 \\
(7.73)\end{array}$ & -0.033 & $\begin{array}{l}-9.00 \\
(7.26)\end{array}$ & -0.025 \\
\hline \multicolumn{11}{|l|}{ Typology $^{b}$} \\
\hline $\begin{array}{l}\text { Non-dependent } \\
\text { (ref) }\end{array}$ & -- & -- & 0 & 0 & -- & -- & 0 & 0 & 0 & 0 \\
\hline Farming & -- & -- & $\begin{array}{c}-40.79 * * * \\
(6.67) \\
\end{array}$ & -0.116 & -- & -- & $\begin{array}{c}-39.75 * * * \\
(6.13) \\
\end{array}$ & -0.113 & $\begin{array}{c}-20.52^{* *} \\
(6.02) \\
\end{array}$ & -0.058 \\
\hline Mining & -- & -- & $\begin{array}{l}52.93 * * * \\
(10.75)\end{array}$ & 0.087 & -- & -- & $\begin{array}{l}36.81 * * * \\
(9.22)\end{array}$ & 0.061 & $\begin{array}{l}34.49 * * * \\
(8.68)\end{array}$ & 0.057 \\
\hline Manufacturing & -- & -- & $\begin{array}{c}3.37 \\
(4.09)\end{array}$ & 0.013 & -- & -- & $\begin{array}{l}-1.08 \\
(3.67) \\
\end{array}$ & -0.004 & $\begin{array}{l}-1.05 \\
(3.46) \\
\end{array}$ & -0.004 \\
\hline Government & -- & -- & $\begin{array}{r}-12.29 \\
(7.01) \\
\end{array}$ & -0.033 & -- & -- & $\begin{array}{l}-1.15 \\
(5.21) \\
\end{array}$ & -0.003 & $\begin{array}{l}-4.06 \\
(4.77) \\
\end{array}$ & -0.011 \\
\hline Service & -- & -- & $\begin{array}{l}-55.56 * * * \\
(6.48)\end{array}$ & -0.144 & -- & -- & $\begin{array}{c}-18.73 * * * \\
(5.15)\end{array}$ & -0.049 & $\begin{array}{c}-21.60 * * * \\
(4.89)\end{array}$ & -0.056 \\
\hline \multicolumn{11}{|l|}{ Medical Care } \\
\hline $\begin{array}{l}\text { Active MDs } \\
\text { (rate) }\end{array}$ & -- & -- & $\begin{array}{c}-14.67 * * * \\
(2.18) \\
\end{array}$ & -0.164 & -- & -- & $\begin{array}{r}2.98^{*} \\
(1.24) \\
\end{array}$ & 0.033 & $\begin{array}{c}0.78 \\
(1.12) \\
\end{array}$ & 0.009 \\
\hline $\begin{array}{l}\text { Hospital Beds } \\
\text { (rate) }\end{array}$ & -- & -- & $\begin{array}{c}1.17^{*} \\
(0.45) \\
\end{array}$ & 0.050 & -- & -- & $\begin{array}{r}0.92^{*} \\
(0.36) \\
\end{array}$ & 0.040 & $\begin{array}{l}0.96^{* * *} \\
(0.36) \\
\end{array}$ & 0.041 \\
\hline $\begin{array}{l}\text { No Health Ins } \\
(\%)\end{array}$ & -- & -- & -- & -- & $\begin{array}{l}-0.00 \\
(0.66) \\
\end{array}$ & -0.000 & $\begin{array}{l}-0.88 \\
(0.75) \\
\end{array}$ & -0.036 & $\begin{array}{c}0.46 \\
(0.73) \\
\end{array}$ & 0.019 \\
\hline \multicolumn{11}{|l|}{ Education } \\
\hline$<\mathrm{HS}^{\mathrm{a}}$ (ref) & -- & -- & -- & -- & 0 & 0 & 0 & 0 & 0 & 0 \\
\hline HS/Some College & -- & -- & -- & -- & $\begin{array}{l}1.12 * \\
(0.52) \\
\end{array}$ & 0.064 & $\begin{array}{l}3.39 * * * \\
(0.63)\end{array}$ & 0.195 & $\begin{array}{l}1.87 * * \\
(0.56)\end{array}$ & 0.107 \\
\hline 4yr College + & -- & -- & -- & -- & $\begin{array}{c}0.81 \\
(0.56)\end{array}$ & 0.048 & $\begin{array}{l}-2.12 * * \\
(0.62) \\
\end{array}$ & -0.126 & $\begin{array}{c}0.75 \\
(0.59) \\
\end{array}$ & 0.045 \\
\hline \multicolumn{11}{|l|}{ Race } \\
\hline Other (ref) & -- & -- & -- & -- & 0 & 0 & 0 & 0 & 0 & 0 \\
\hline White & -- & -- & -- & -- & $\begin{array}{l}-1.96 * * * \\
(0.48) \\
\end{array}$ & -0.261 & $\begin{array}{l}-3.37 * * * * \\
(0.53) \\
\end{array}$ & -0.450 & $\begin{array}{l}-2.06 * * * \\
(0.49) \\
\end{array}$ & -0.274 \\
\hline Black & -- & -- & -- & -- & $\begin{array}{l}-1.18^{*} \\
(0.52)\end{array}$ & -0.148 & $\begin{array}{l}-3.79 * * * \\
(0.55) \\
\end{array}$ & -0.476 & $\begin{array}{l}-1.45^{* *} \\
(0.54) \\
\end{array}$ & -0.182 \\
\hline \multicolumn{11}{|l|}{ Health Indicator } \\
\hline Obesity & -- & -- & -- & -- & $\begin{array}{l}3.92 * * * \\
(0.78)\end{array}$ & 0.165 & $\begin{array}{l}3.42 * * * \\
(0.91)\end{array}$ & 0.144 & $\begin{array}{l}3.89 * * * \\
(0.81)\end{array}$ & 0.164 \\
\hline
\end{tabular}




\begin{tabular}{|c|c|c|c|c|c|c|c|c|c|c|}
\hline Physical Activity & -- & -- & -- & -- & $\begin{array}{l}-2.85 * * * \\
(0.49)\end{array}$ & -0.190 & $\begin{array}{l}-6.20 * * * \\
(0.53)\end{array}$ & -0.413 & $\begin{array}{l}-2.94 * * * \\
(0.49)\end{array}$ & -0.196 \\
\hline Smoking & -- & -- & -- & -- & $\begin{array}{l}13.21 * * * \\
(0.70)\end{array}$ & 0.417 & -- & -- & $\begin{array}{l}12.18 * * * \\
(0.72)\end{array}$ & 0.385 \\
\hline \multicolumn{11}{|l|}{ Labor Force } \\
\hline $\begin{array}{l}\text { Unemployed } \\
\text { (rate) }\end{array}$ & -- & -- & -- & -- & $\begin{array}{l}0.45^{* * * *} \\
(0.09)\end{array}$ & 0.106 & -- & -- & $\begin{array}{l}0.31 * * \\
(0.10)\end{array}$ & 0.074 \\
\hline \multicolumn{11}{|l|}{ Inequality } \\
\hline $\operatorname{Gini}^{\mathrm{d}}$ & -- & -- & $\begin{array}{l}7.21 * * * \\
(0.75)\end{array}$ & 0.232 & -- & -- & $\begin{array}{l}4.65^{* * * *} \\
(0.74)\end{array}$ & .150 & $\begin{array}{l}2.28 * * \\
(0.70)\end{array}$ & 0.074 \\
\hline $\mathbf{N}$ & \multicolumn{2}{|c|}{3,070} & \multicolumn{2}{|c|}{3,070} & \multicolumn{2}{|c|}{3,070} & \multicolumn{2}{|c|}{3,070} & \multicolumn{2}{|c|}{3,070} \\
\hline Adj. $R^{2}$ & \multicolumn{2}{|c|}{0.2942} & \multicolumn{2}{|c|}{0.3996} & \multicolumn{2}{|c|}{0.6063} & \multicolumn{2}{|c|}{0.5653} & \multicolumn{2}{|c|}{0.6174} \\
\hline AIC & \multicolumn{2}{|c|}{37031.92} & \multicolumn{2}{|c|}{36551.61} & \multicolumn{2}{|c|}{35249.21} & \multicolumn{2}{|c|}{35566.72} & \multicolumn{2}{|c|}{35176.55} \\
\hline BIC & \multicolumn{2}{|c|}{37086.18} & \multicolumn{2}{|c|}{36702.35} & \multicolumn{2}{|c|}{35357.74} & \multicolumn{2}{|c|}{35759.66} & \multicolumn{2}{|c|}{35381.55} \\
\hline
\end{tabular}

Note. Coefficients with robust standard error in parentheses. ${ }^{*} \mathrm{p}<0.05, * * \mathrm{p}<0.01, * * * \mathrm{p}<0.001$

Dependent variable: Female mortality (rates) in 2010 (2008-2012)

${ }^{\mathrm{a}}=$ Rural Urban Continuum Code (2003)

${ }^{\mathrm{b}}=(2004) ;($ all other control variables are 2000 unless otherwise noted)

${ }^{\mathrm{c}}=$ Age $25+;(\%)$

${ }^{\mathrm{d}}=$ Gini Index multiplied times 100 to see increment changes 
Figure 1. US Census Bureau's Divisions

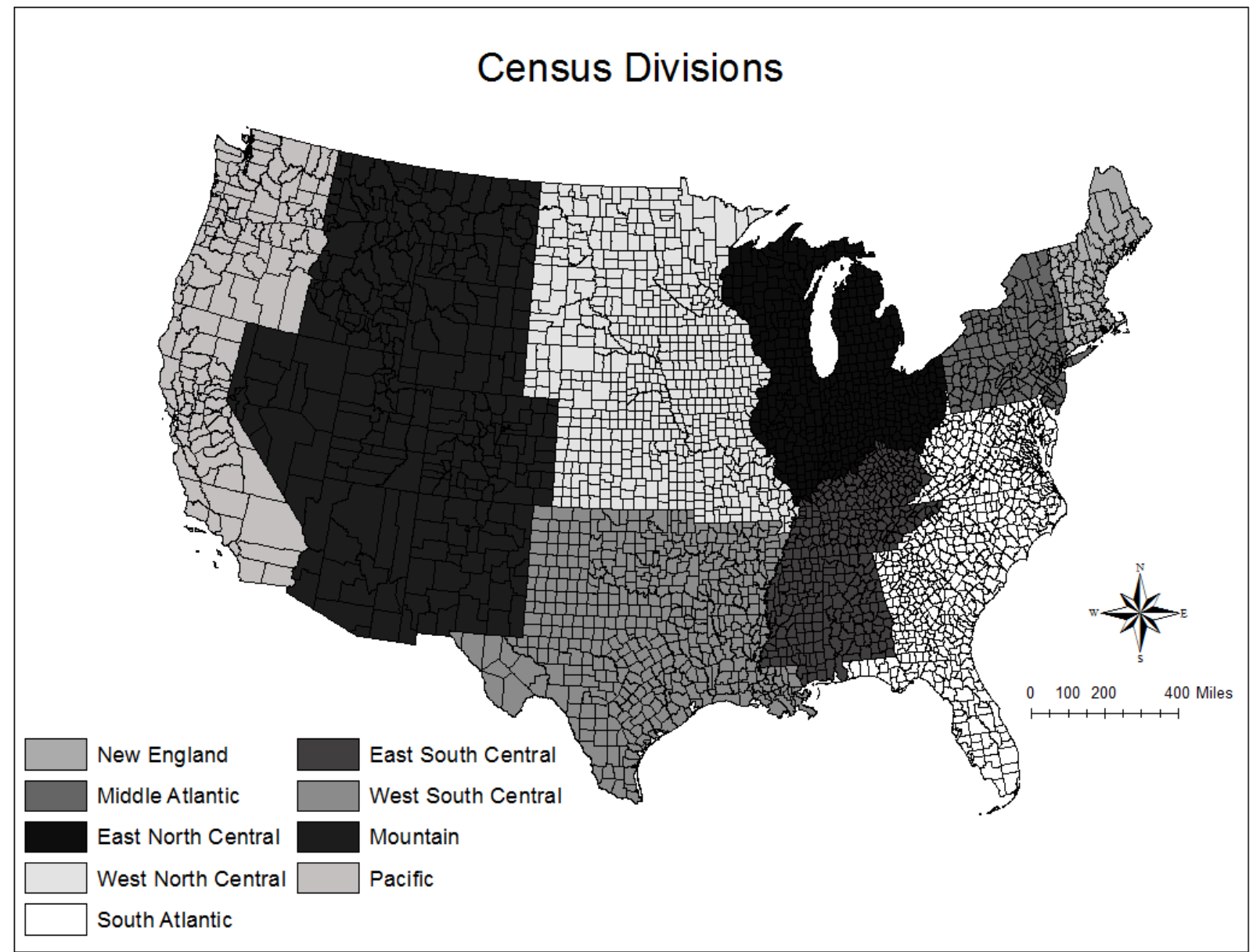

Note: It is ill-advised to create monochrome choropleth maps with so many categories, but due to printing considerations, all figures are in black and white. The counties are too small to fill with patterns to differentiate either. See Literature Review section to determine which nations are which based on descriptions if colors are too similar. 
Figure 2. Woodard's "American Nations"

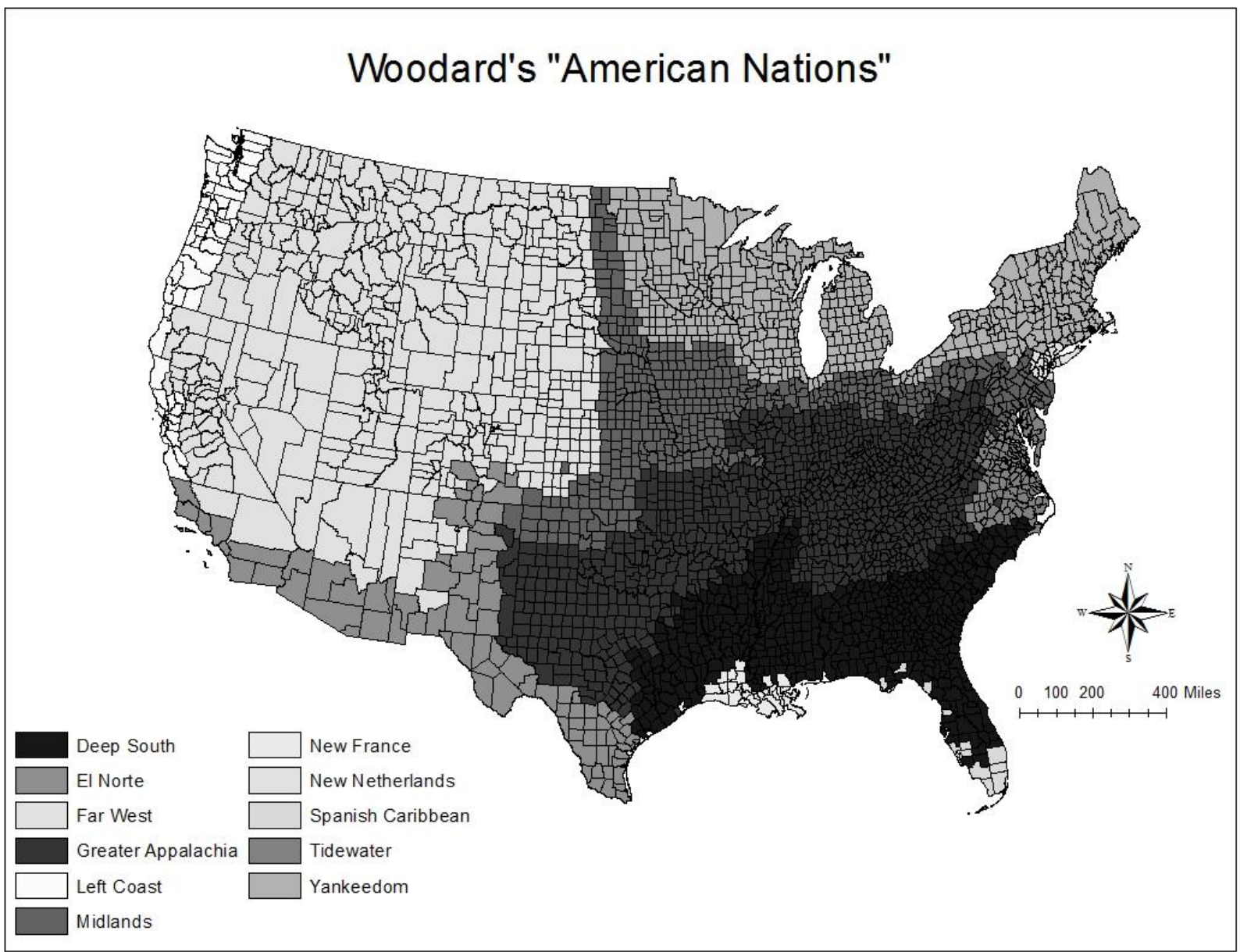

Note: It is ill-advised to create monochrome choropleth maps with so many categories, but due to printing considerations, all figures are in black and white. The counties are too small to fill with patterns to differentiate either. See Literature Review section to determine which nations are which based on descriptions if colors are too similar. 
Figure 3. Garreau's "Nine Nations"

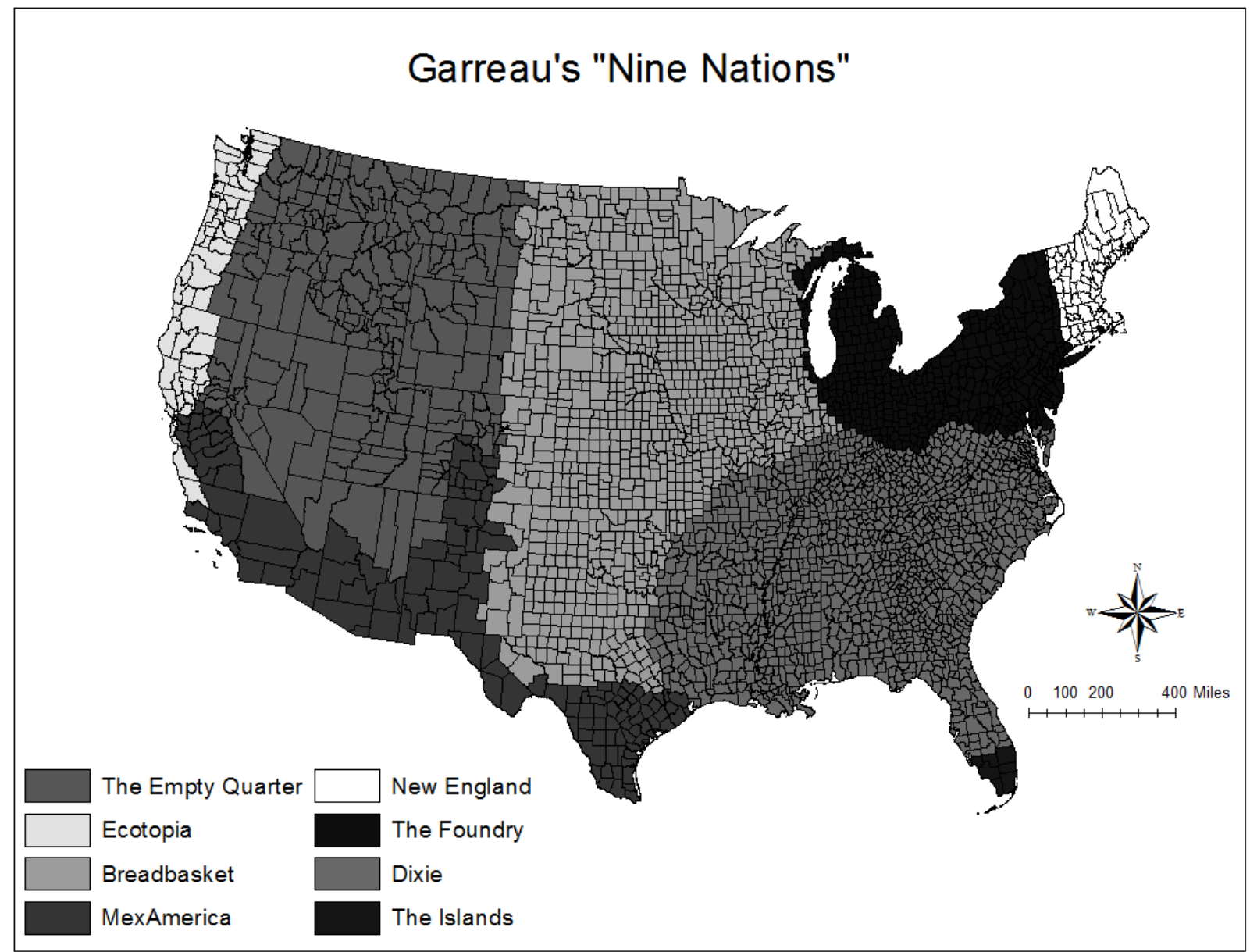

Note: It is ill-advised to create monochrome choropleth maps with so many categories, but due to printing considerations, all figures are in black and white. The counties are too small to fill with patterns to differentiate either. See Literature Review section to determine which nations are which based on descriptions if colors are too similar. 
Figure 4. Male Age-Adjusted All-Cause US Mortality with Census Divisions

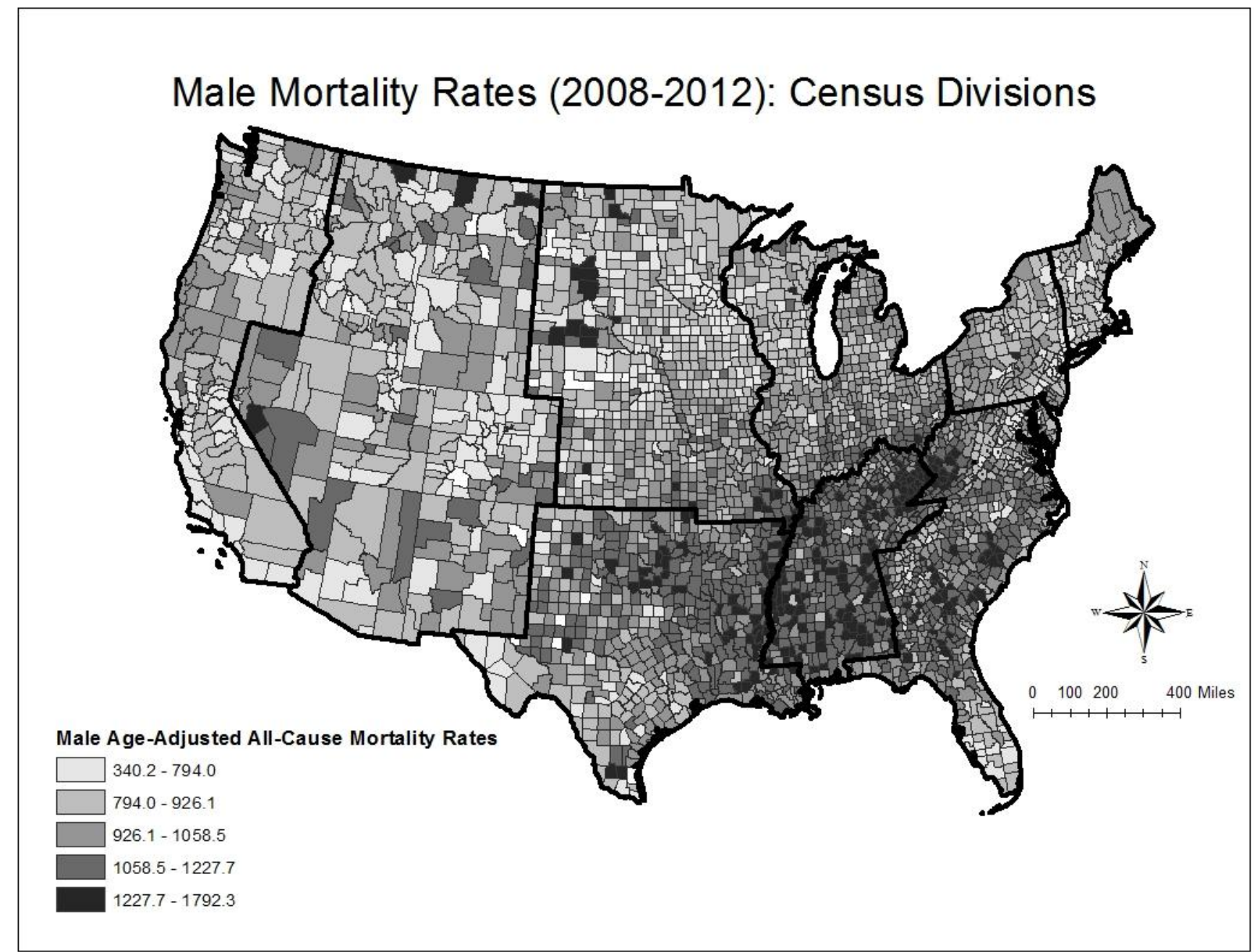

Note: Rates are per 100,000 males. 
Figure 5. Female Age-Adjusted All-Cause US Mortality with Census Divisions

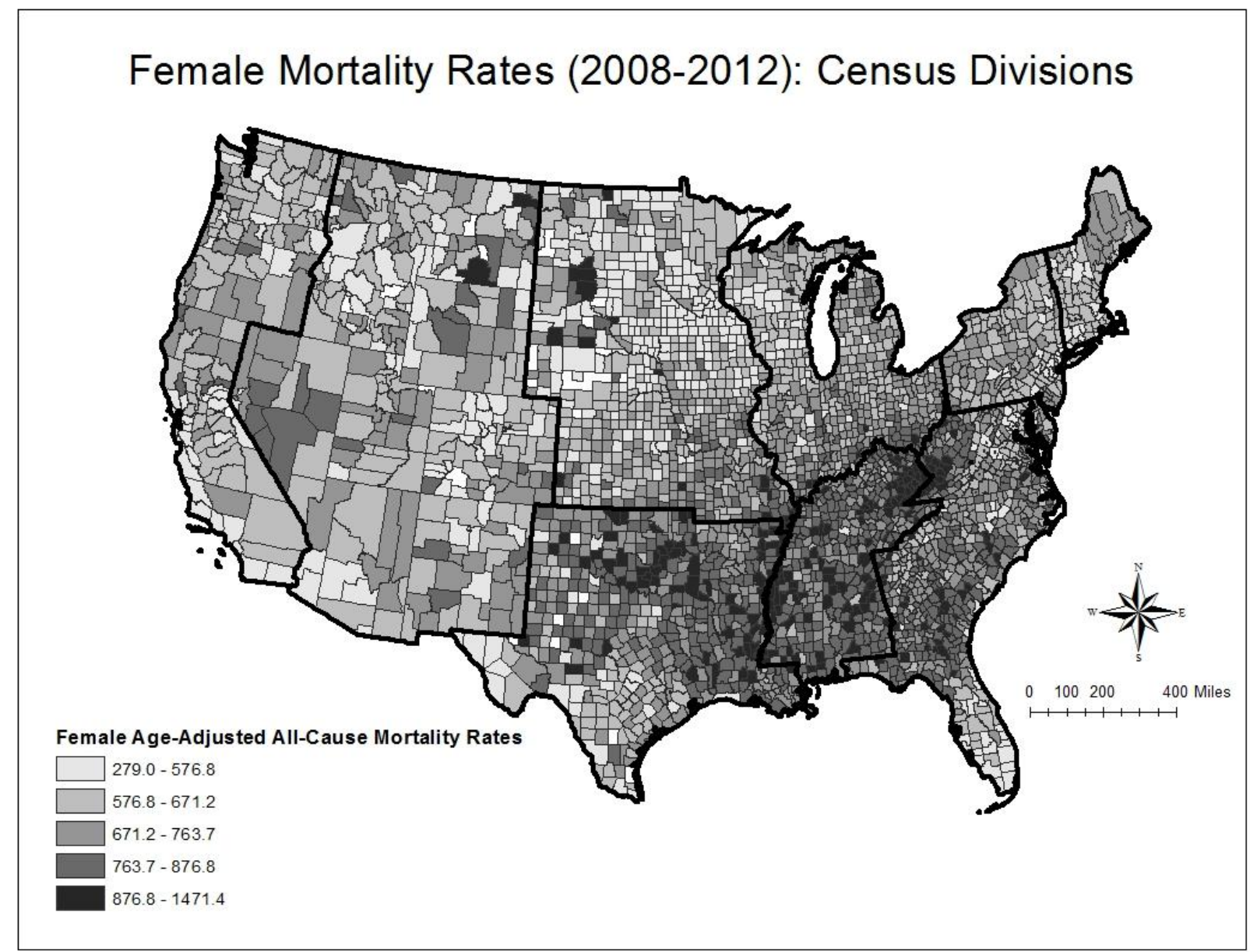

Note: Rates are per 100,000 females 
Figure 6. Male Age-Adjusted All-Cause US Mortality with Woodard's "American Nations"

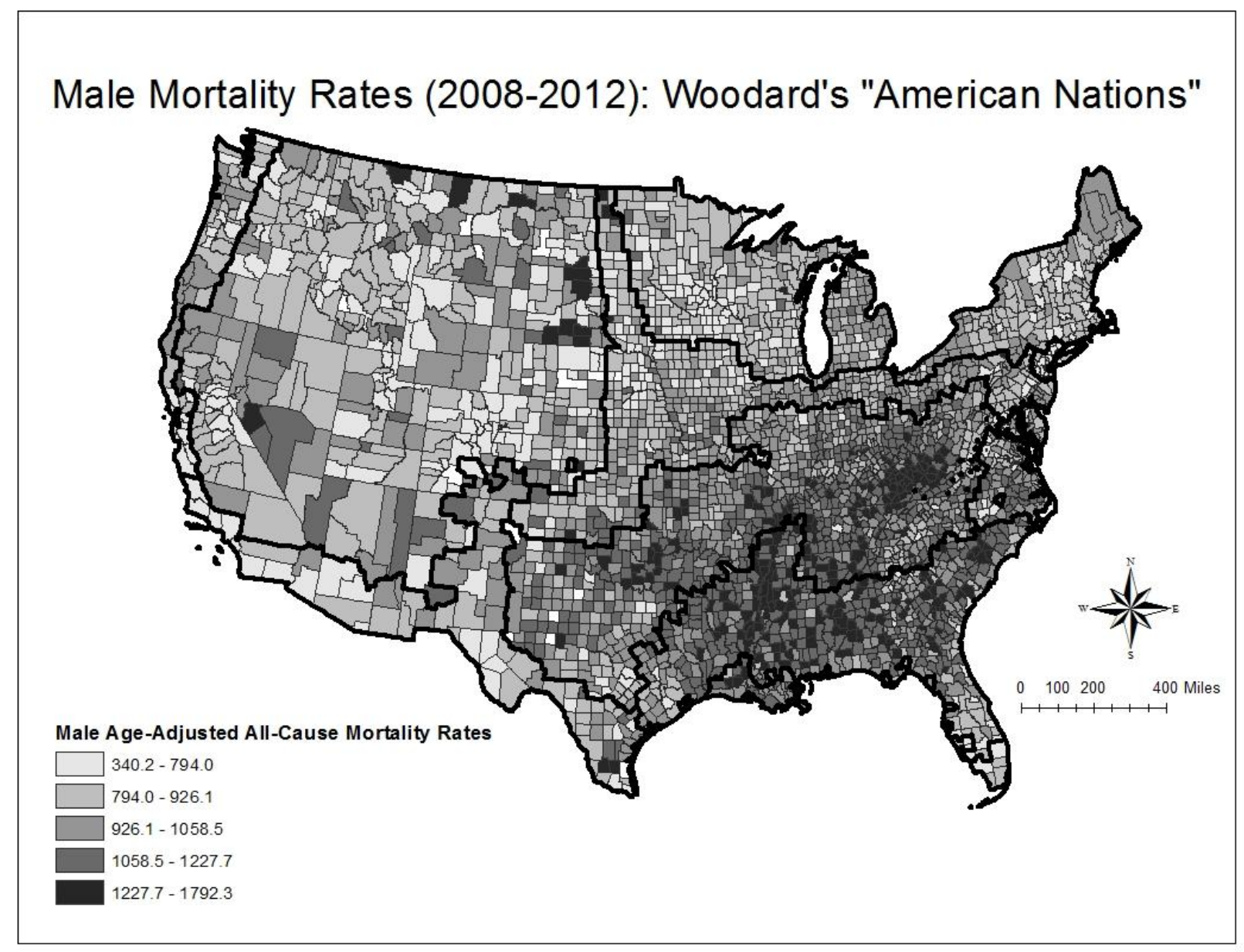

Note: Rates are per 100,000 males. 
Figure 7. Female Age-Adjusted All-Cause US Mortality with Woodard's "American Nations"

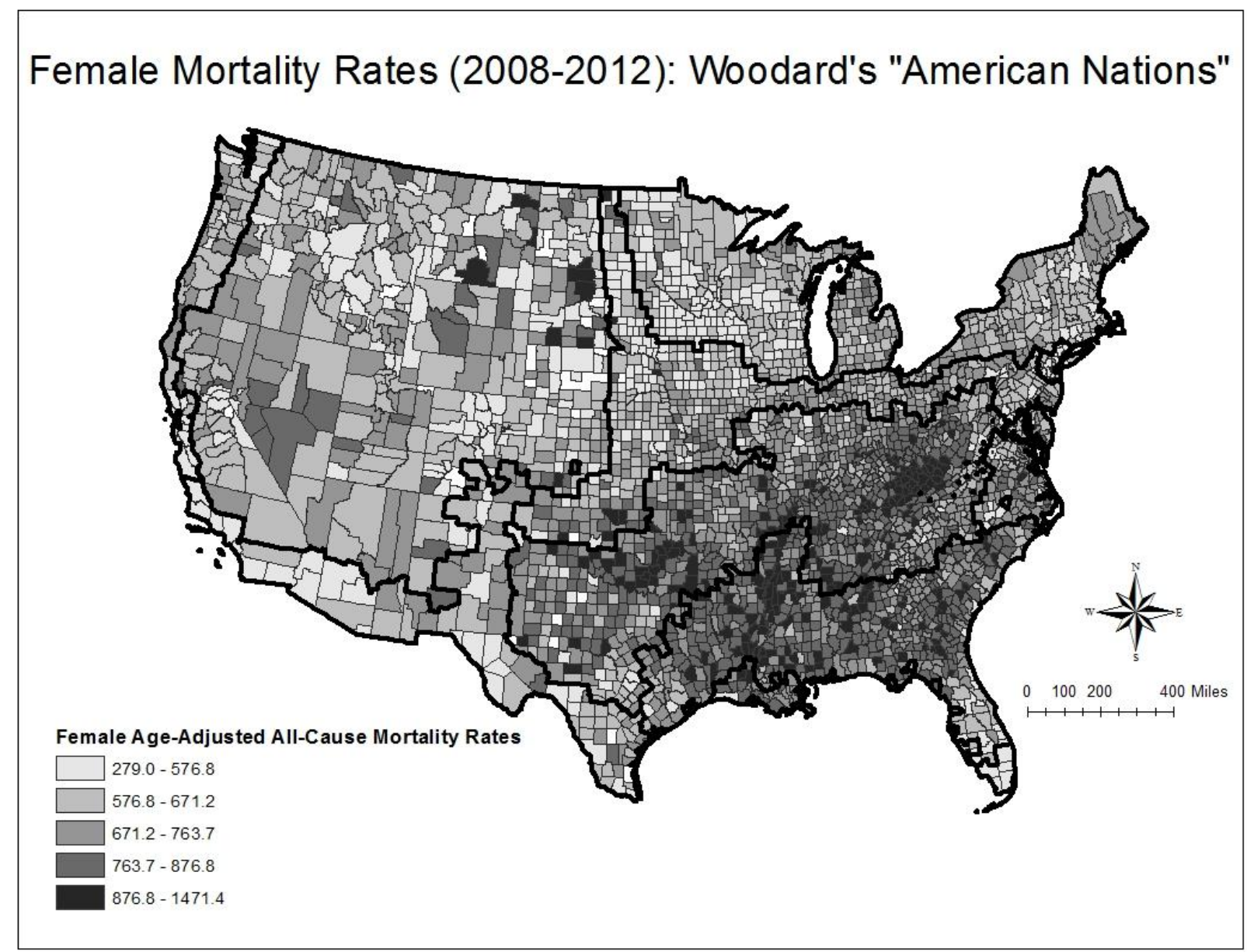

Note: Rates are per 100,000 females. 
Figure 8. Male Age-Adjusted All-Cause US Mortality with Garreau's "Nine Nations"

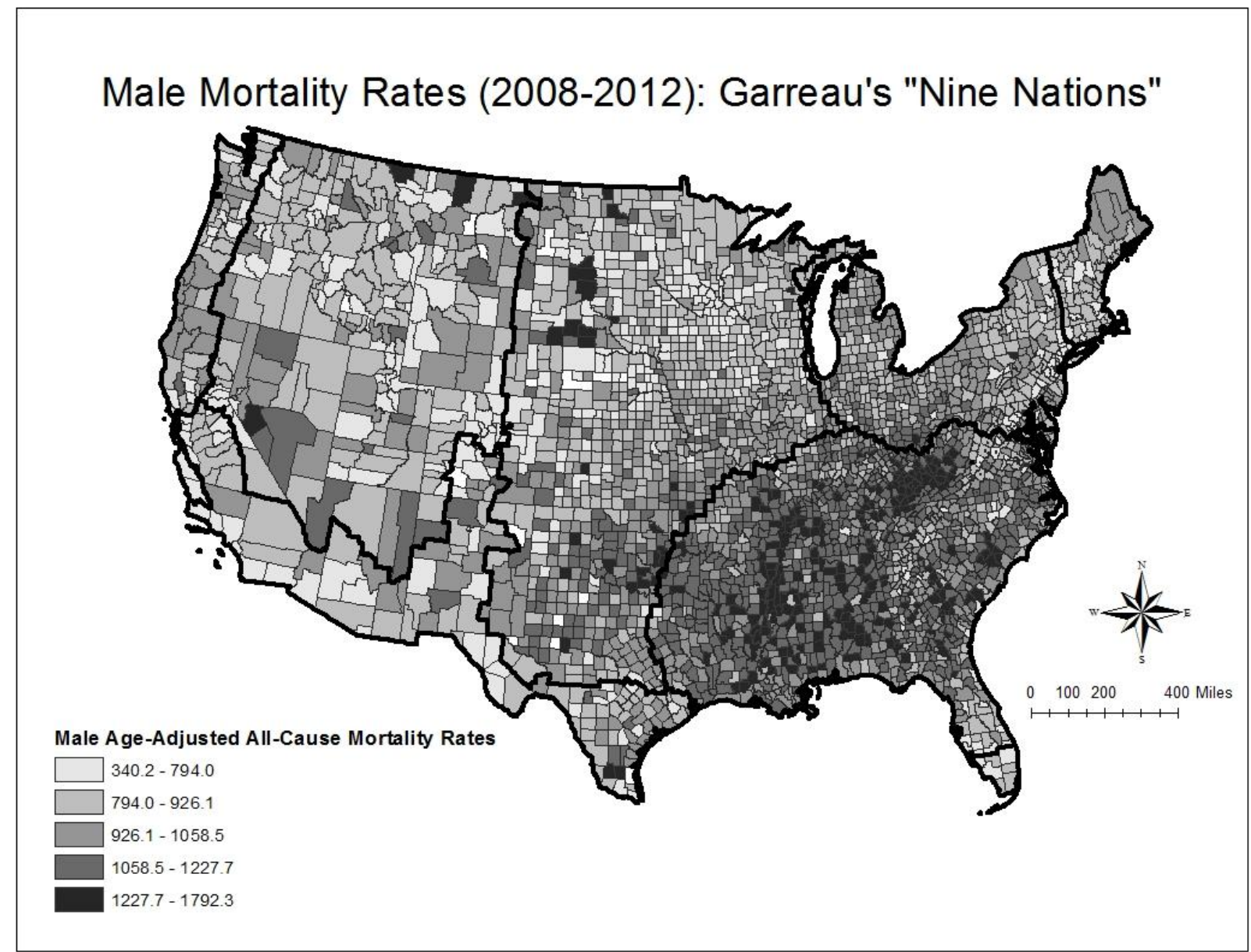

Note: Rates are per 100,000 males. 
Figure 9. Female Age-Adjusted All-Cause US Mortality with Garreau's "Nine Nations"

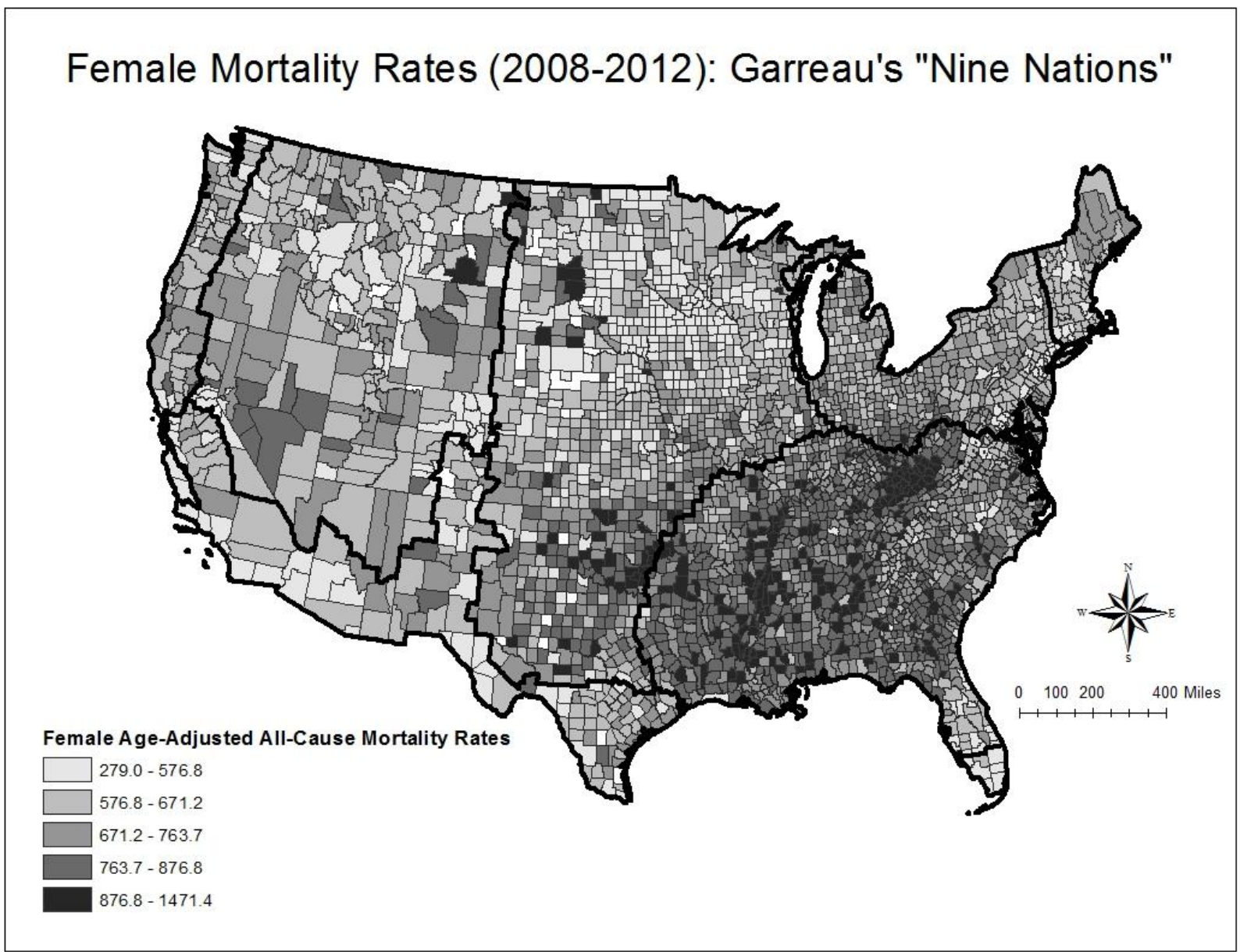

Note: Rates are per 100,000 females. 
Figure 10. Male Age-Adjusted All-Cause US Mortality with Woodard, Garreau, and Census Classifications

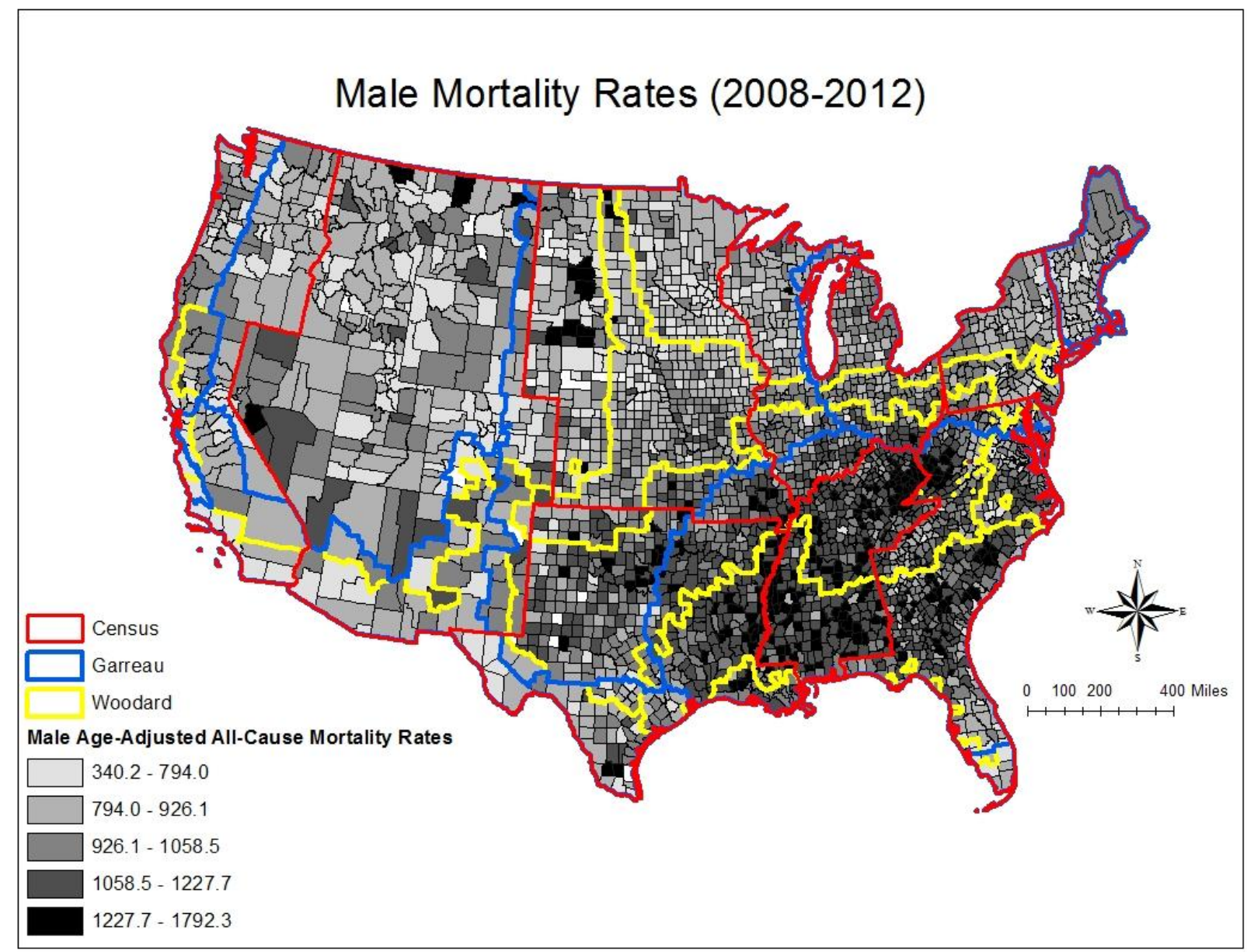

Note: Rates are per 100,000 males. 
Figure 11. Female Age-Adjusted All-Cause US Mortality with Woodard, Garreau, and Census Classifications

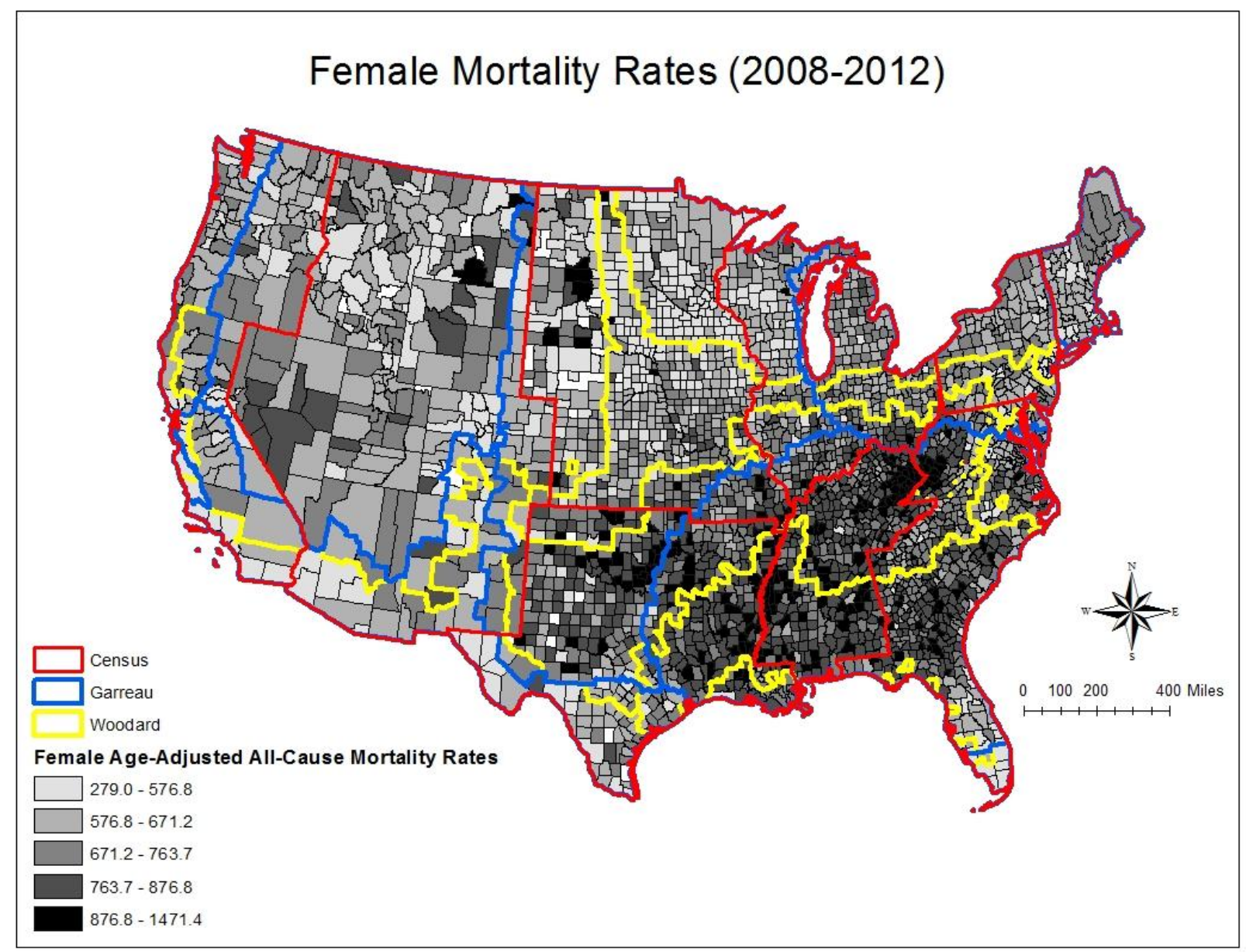

Note: Rates are per 100,000 females. 